UNIVERSIDAD NACIONAL DE LA PLATA

FACULTAD DE CIENCIAS EXACTAS

DEPARTAMENTO DE QUÍMICA

\title{
"ALTERNATIVAS TECNOLÓGICAS QUE PERMITAN LA ELABORACIÓN DE PRODUCTOS CONFORMADOS RICOS EN ÁCIDOS GRASOS POLI-INSATURADOS, A PARTIR DE UNA ESPECIE MARINA GRASA SUB-EXPLOTADA (SARACA, Brevoortia aurea)"
}

Susana Carolina Pennisi Forell

Directora:

Dra Alicia Noemi Califano

Codirector:

Ing. Emilio Aldo Manca. 

El presente trabajo de Tesis para optar al título de Doctora en Ciencias Exactas fue realizado en el Instituto Nacional de Investigación y Desarrollo Pesquero, organismo descentralizado dependiente del Ministerio de Agricultura, Ganadería y Pesca, y en el CIDCA (Centro de Investigación y Desarrollo en Criotecnología de Alimentos), Conicet-Facultad de Ciencias Exactas de la UNLP, bajo la dirección de la Dra. Alicia Noemí Califano y la codirección del Ing. Emilio Manca.

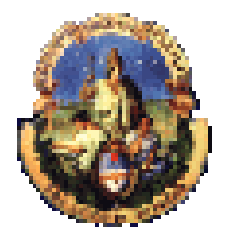

U N L P

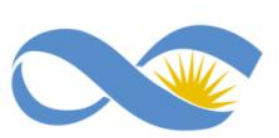

C O N I C E T

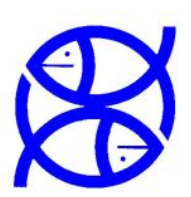

I N I D E P

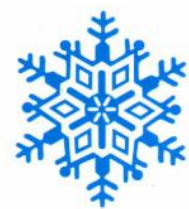

C I D C A 



\section{Agradecimientos}

Desde estas líneas deseo expresar mi más profundo y sincero agradecimiento a todas aquellas personas e instituciones que con su ayuda han colaborado $y$ participado para que pueda realizar esta Tesis Doctoral.

En especial mi mayor agradecimiento es para mis directores de Tesis, la Dra. Alicia Califano y el Ing. Emilio Manca, quienes me orientaron, apoyaron, motivaron y me dieron ánimos tanto a nivel académico como personal. Les agradezco de corazón la confianza que depositaron en mi para realizar el trabajo, el tiempo que destinaron siempre para responder a mis consultas y dudas, la paciencia, los buenos consejos y el cariño que día a día me demuestran.

Al Director Nacional de Investigación, Dr. Otto Wöhler, por haberme brindado la posibilidad de desarrollar el presente trabajo de Tesis en las instalaciones del Instituto Nacional de Investigación y Desarrollo Pesquero (INIDEP). A la Dra Noemí Zaritzky y Dr. Rodolfo Mascheroni por permitirme realizar parte de los ensayos en los laboratorios del Centro de Investigación y Desarrollo en Criotecnología de Alimentos (CIDCA) (CONICET La Plata - UNLP).

A las siguientes instituciones $y$ entidades que mediante diversos tipos de financiamiento posibilitaron la realización del presente trabajo de Tesis, al Consejo Nacional de Investigaciones Científicas y Técnicas (CONICET), al Ministerio de Agricultura, Ganadería Y Pesca de La Nación, a la Universidad Nacional de La Plata (UNLP).

A la Dra. Silvia Inés Incorvaia, por su contribución en el análisis parasitológico de las muestras, pero principalmente quiero expresarle mi agradecimiento y todo mi aprecio, por haberme dado cariño y afecto cuando lo necesité, gracias Sil!!.

Al Dr. Gustavo Macchi y a Marta por su colaboración en el análisis histológico de las gónadas.

A la flota costera de Mar del Plata y también al personal de muestreo del INIDEP, a Pablo Izzo, que me ayudó muchas veces a conseguir las muestras de pescado y viajar hasta Lavalle a buscarlo. A Martín Bertelo, que arregló equipos indispensables cuando se rompían o fallaban y que me ayudó a diseñar aquellos dispositivos para la Tesis. Y a Silvana Guccione de Omega Sur por incontables aportes.

Al Téc. Rafael Bonavigna, a la Lic. Carola Velez, a la Bioq. Alejandra Bó y Dr. Horacio Sancho de SENASA quienes me han enseñado sobre reglamentación Nacional en el ámbito pesquero. 
A la Dra. Silvina Andrés, quien mucho tiempo antes de comenzar a transitar este camino Doctoral, me abrió las puertas al mundo de la Ciencia e hizo que descubra la pasión por la Investigación.

A Andy, a Mari, a July, a Ricky, a Eze y a todos con quienes compartí miles de horas y momentos en el INIDEP. A los chicos del CIDCA, Nachito, Nati, Cristian, Anabel, Vicky y Gaby quienes siempre me brindaron una cálida recibida cada vez que viajaba a La Plata y con quienes compartí cursos, congresos, viajes y siempre, a pesar de vernos poco, me hicieron sentir una más del grupo.

A mis amigas del alma e incondicionales siempre, Luchi, Mari, Luly, Jessy, Fer, Ferchu. A Anita y Jime que además de amigas del alma e incondicionales son amigas en la aventura (NZ, donde todos los días pasa algo sorprendente). A Gaby, que desde la distancia diariamente me da apoyo, ánimos y mucho cariño para que concluya esta etapa.

A mi hermano Ricky y sobrino Fran que siempre me alegran y me hacen reír mucho, por confiar y apoyarme en mis ideas "locas".

Y especialmente le agradezco y dedico esta Tesis con todo mi amor a mi mamá y mi papá, que siempre me guían con un cariño incondicional y me dan fuerzas para seguir adelante. Además también, porque de una manera u otra, participaron de la Tesis, desde acompañarme en la madrugada miles de veces al puerto, para ver si había entrado algún barco con saracas, hasta filetear cajones y cajones de pescado... Gracias Pá!! Y a Má, por pasar conmigo hasta un día de la madre anotando datos morfométricos porque justo ese domingo entró pescado fresco y había que analizarlo....Gracias Má!!

A todos, muchas gracias. 
INDICE

$\begin{array}{ll}\text { INDICE } & 7\end{array}$

$\begin{array}{ll}\text { RESUMEN } & 13\end{array}$

Capítulo I

INTRODUCCIÓN GENERAL $\quad 15$

I.1. La pesca y consumo 15

I.1.1. Clasificación de las especies pesqueras 18

$\begin{array}{ll}\text { I.1.2. Músculo de pescado } & 19\end{array}$

I.1.3. Ciclo Biológico 21

I.2. Componentes funcionales en alimentos 23

I.2.1. Los alimentos funcionales 23

I.2.2. Lípidos presentes en los alimentos 24

I.2.3. Consumo de ácidos grasos $n-3$ en la dieta 29

I.2.4. EPA, DHA y la salud 30

I.2.5. Fuente de ácidos grasos omega-3 31

I.2.6. Recomendaciones sobre el consumo diario de lípidos 32 Recomendaciones en el consumo de PUFA 32

Índice de aterogenicidad y trombogenicidad 33

I.2.7. Deterioro de los ácidos grasos poli-insaturados $\quad 34$

I.2.8. Mecanismo de oxidación de los lípidos insaturados 36 Iniciación 37

Propagación $\quad 37$

$\begin{array}{ll}\text { Terminación } & 37\end{array}$

I.2.9. Control de la velocidad de la oxidación de los lípidos en los alimentos 38

I.2.10. Antioxidantes utilizados en alimentos 38

Antioxidantes naturales $\quad 39$

Antioxidantes sintéticos $\quad 45$

I.2.11. Los fitoesteroles $\quad 46$

I.3.Desarrollo de productos conformados en la Industria Pesquera $\quad 50$

I.3.1. Argentina como productor $\quad 50$

I.3.2. Desmenuzado de pescado $\quad 51$

I.3.3. Obtención de desmenuzado mecánicamente 52

$\begin{array}{ll}\text { I.3.4. Equipamiento } & 53\end{array}$

I.3.5. Almacenamiento $\quad 53$

I.3.6. Desarrollo de productos con desmenuzado 54

\section{Capítulo II}

$\begin{array}{ll}\text { OBJETIVOS } & 57\end{array}$

Objetivos específicos $\quad 57$

\section{Capítulo III}

CARACTERIZACIÓN DEL CICLO BIOLÓGICO Brevoortia aurea $\quad 59$ III.1. Género Brevoortia $\quad 59$ 
III.1.1.Especie Brevoortia aurea $\quad 59$

III.1.2.Composición química 61

III.1.3.Índices morfométricos $\quad 62$

III.2. Materiales y Métodos $\quad 62$

III.2.1.Material utilizado $\quad 62$

III.2.2.Preparación y acondicionamiento de las muestras 62

III.2.3.Cálculo de parámetros morfométricos 64

III.2.4. Índices morfológicos $\quad 64$

Factor de condición eviscerado (FCev) 64

Índice gonadosomático (IGS) 65

Índice somático (IS) 65

III.2.5. Determinación del sexo y estadio sexual 65

III.2.6. Análisis de composición centesimal 65

Humedad $\quad 65$

Cenizas $\quad 65$

Proteína $\quad 66$

Lípidos $\quad 67$

Perfil de ácidos grasos $\quad 67$

III.2.7. Análisis estadístico $\quad 67$

III.3 Resultados y Discusión 68

III.3.1. Características del muestreo 68

III.3.2. Cálculo de parámetros morfométricos $\quad 71$

III.3.3. Análisis de composición centesimal $\quad 74$

III.3.4. Perfil ácidos grasos $\quad 76$

III. 4. Conclusiones $\quad 79$

\section{Capítulo IV}

ALMACENAMIENTO CONGELADO DE DESMENUZADO DE MÚSCULO DE

SARACA: Cambios en las propiedades tecnológicas de la proteína 81

IV.1. Congelación y almacenamiento congelado 81

IV.2. Materiales y Métodos $\quad 82$

IV.2.1. Preparación del desmenuzado de pescado 82

IV.2.2. Congelación de las muestras $\quad 84$

IV.2.3. Análisis proximal $\quad 84$

IV.2.4. Capacidad de retención de agua (WHC) 84

IV.2.5. Pérdidas por "drip" $\quad 85$

IV.2.6. Desnaturalización proteica 86

IV.2.7. Microestructura por microscopía de barrido electrónico (SEM) 86

IV.2.8. Propiedades de la emulsión 87

Aislamiento de proteínas sarcoplasmáticas y miofibrilares de saraca $\quad 87$

Determinación del índice de actividad de la emulsión 87

IV.2.9. Análisis estadístico 88

IV.3. Resultados y Discusión 88

IV.3.1. Composición en los diferentes estadios de madurez sexual $\quad 88$

IV.3.2.Efecto del almacenamiento congelado en la desnaturalización

$\begin{array}{ll}\text { proteica } & 89\end{array}$

IV.3.3. Cambios en la capacidad de retención de agua y pérdidas 
por "drip" debido al almacenamiento congelado

III.3.4. Estructura de las fibras de proteínas de músculo de pescado con microscopía electrónica de barrido - SEM

IV.3.5. Índice de actividad de la emulsión $\quad 95$

IV.4. Conclusiones

\section{Capítulo V}

ALMACENAMIENTO CONGELADO DE DESMENUZADO DE MÚSCULO DE SARACA:

Efecto del agregado de antioxidantes $\quad 99$

V.1. Oxidación de los lípidos durante el almacenamiento congelado 99

$\begin{array}{ll}\text { V.2. Materiales y Métodos } & 100\end{array}$

V.2.1. Material utilizado 100

V.2.2. Preparación del pescado $\quad 101$

V.2.3. Preparación del desmenuzado 101

V.2.4. Incorporación de antioxidantes en el desmenuzado

$\begin{array}{ll}\text { de pescado } & 102\end{array}$

V.2.5. Congelación de las muestras $\quad 103$

V.2.6. Oxidación lipídica 103

V.2.7. Color 104

V.2.8. Diseño experimental y análisis estadístico de los resultados 104

$\begin{array}{ll}\text { V.3. Resultados y Discusión } & 105\end{array}$

V.3.1. Rendimiento 105

V.3.2. Oxidación lipídica $\quad 105$

V.3.3. Color 108

V.4. Conclusiones 112

\section{Capítulo VI}

ALMACENAMIENTO CONGELADO DE DESMENUZADO DE MÚSCULO DE SARACA:

Calidad higiénico-sanitaria 113

VI.1. Calidad del pescado $\quad 113$

VI.1.1. Nitrógeno básico volátil total $\quad 114$

VI.1.2. Microorganismos en el desmenuzado de pescado 116

VI.1.3. Histamina en desmenuzado de pescado 117

VI.1.4. Espinas en desmenuzado de pescado $\quad 119$

VI.1.5. Parásitos $\quad 120$

VI.2.Materiales y Métodos 122

VI.2.1. Material utilizado $\quad 122$

VI.2.2. Determinación de nitrógeno básico volátil total 122

VI.2.3. Recuento microbiano 123

Recuento de microorganismos totales y psicrótrofos $\quad 124$

VI.2.4. Determinación de histamina $\quad 124$

VI.2.5. Cuantificación de espinas $\quad 125$

VI.2.6. Presencia de parásitos $\quad 126$

VI.2.7. Análisis estadístico $\quad 126$

VI.3. Resultados y Discusión $\quad 126$

VI.3.1. Nitrógeno básico volátil total 126 
VI.3.2. Recuentos microbianos $\quad 128$

VI.3.3. Histamina $\quad 129$

VI.3.4. Cuantificación de espinas $\quad 129$

VI.3.5. Presencia de parásitos $\quad 132$

VI.4. Conclusiones 133

\section{Capítulo VII}

DESARROLLO DE CONFORMADOS DE SARACA (Brevoortia aurea) 135

VII.1. Características en el consumo actual 135

VII.1.1. Características en el consumo de pescado 137

VII.1.2. Productos estructurados a partir de desmenuzado de

$\begin{array}{ll}\text { Pescado } & 138\end{array}$

VII.2. Materiales y Métodos $\quad 142$

VII.2.1. Materia prima y preparación de las muestras 142

Otros ingredientes y aditivos 142

VII.2.2. Diseño Experimental A - Evaluación de la efectividad de un antioxidante natural en relación al uso de uno sintético aplicado en hamburguesas de pescado

Elaboración de hamburguesas de saraca 145

Oxidación lipídica 146

VII.2.3. Diseño Experimental B - Estudio de los cambios en los parámetros de calidad de hamburguesas de saraca, crudas y cocidas, durante su almacenamiento a -25ํㅡ 146

Cocción de las hamburguesas $\quad 147$

Análisis de composición centesimal 148

Rendimiento de la cocción 148

Reducción del tamaño 148

Retención de humedad $\quad 148$

Jugosidad por presión $\quad 149$

Retención de lípidos $\quad 149$

Perfil de ácidos grasos $\quad 150$

Valor calórico total $\quad 150$

Textura 150

Color $\quad 151$

Recuentos microbianos $\quad 151$

Ensayo de aceptabilidad por consumidores $\quad 152$

Análisis estadístico de los resultados $\quad 154$

VII.3. Resultados y Discusión 154

VII.3.1. Caracterización de la carne de saraca como materia prima 154

VII.3.2. Diseño Experimental A - Evaluación de la efectividad de un antioxidante natural en relación al uso de uno sintético aplicado en hamburguesas de pescado

VII.3.3. Diseño experimental B- Estudio de los cambios en los parámetros de calidad de conformados de saraca, crudas y cocidas, durante su almacenamiento a $-25^{\circ} \mathrm{C} \quad 161$

Rendimiento de la cocción 162

Reducción del tamaño $\quad 164$

Retención de agua $\quad 165$ 
Índice - 11

Jugosidad por presión 167

Retención de lípidos $\quad 168$

Perfil de ácidos grasos $\quad 169$

Valor calórico total 173

Textura 173

Color $\quad 180$

Microbiología 185

Ensayo de aceptabilidad por consumidores $\quad 187$

VII.4. Conclusiones 189

Capítulo VIII

CONCLUSIONES GENERALES 191

$\begin{array}{ll}\text { BIBLIOGRAFÍA } & 195\end{array}$ 



\section{RESUMEN}

El presente trabajo de Tesis pretende realizar un aporte a la industria pesquera, en el desarrollo y utilización de especies marinas sin valor comercial. En este caso se busca darle utilidad a la especie conocida como saraca (Brevoortia aurea), la cual se pesca a lo largo del año y principalmente como fauna acompañante durante la zafra de la corvina rubia (Micropogonias furnieri); al no tener valor en el mercado se la descarta. Los volúmenes capturados son considerables por lo que se decidió utilizarla como posible fuente de materia prima para el desarrollo de alimentos. Esta especie es pelágica y pertenece a la familia de los clupeidos, por lo cual se sospechaba debía presentar valores elevados de ácidos grasos poli-insaturado ( $n-3)$, los cuales como se sabe aportan beneficios para la salud. Actualmente este tipo de alimentos ricos en $n-3$, tiene una enorme aceptación entre los consumidores que hoy no sólo buscan una nutrición básica, sino que prefieren aquellos que mejoran su salud y por consiguiente su calidad de vida, en un mundo donde las exigencias para los individuos son cada vez mayores.

Para este trabajo se caracterizó, en primera instancia, la composición química del músculo de la saraca a lo largo de su ciclo biológico, ya que en los peces cambia considerablemente según la especie. En una segunda instancia, conociendo las fluctuaciones en la composición química y perfil lipídico, se analizó el comportamiento de la materia prima durante su almacenamiento congelado. Asimismo se evaluó la incorporación de antioxidantes naturales frente a los sintéticos para evitar el deterioro de los ácidos grasos poli-insaturados. En una tercera etapa se desarrollaron 8 formulaciones de hamburguesas de pescado, y se aprovechó la matriz para enriquecer los productos con fitoesteroles, proteínas lácticas, ácido ascórbico y ácidos grasos n-3 y $n-9$. Se redujo el porcentaje de cloruro de sodio respecto a productos comerciales y se evitó la incorporación de harinas o productos derivados de trigo. De esta manera se incrementó su calidad como producto funcional, desarrollando un producto apto para personas con celiaquía y/o hipertensión. Finalmente, se evaluó su almacenamiento congelado a lo largo del tiempo.

El presente trabajo se ordenó en Capítulos:

El Capítulo I corresponde a la Introducción, y en ella se abordan, en primer lugar, aspectos generales de la pesca y consumo de pescado, las características de los pescados, los aspectos generales del ciclo biológico de los peces, la composición y los cambios químicos. Posteriormente se desarrollaron los temas relacionados con alimentos funcionales, tales como: el pescado y los n-3 como alimento funcional, recomendaciones de consumo, el uso de antioxidantes naturales y la incorporación de nutrientes benéficos para la salud como los fitoesteroles. El final del Capítulo 1, se refiere al desarrollo de productos conformados para la industria pesquera, haciendo hincapié en la importancia de utilizar especies con bajo valor comercial, de descarte o restos de otras líneas de procesamiento como materia prima.

En el Capítulo 2 se definen los objetivos generales y específicos de este trabajo de Tesis.

El Capítulo 3 abarca la caracterización del tejido muscular de la Brevoortia aurea, saraca, a lo largo de su ciclo biológico.

El Capítulo 4 comprende el estudio del almacenamiento congelado de músculo desmenuzado abarcando todo el ciclo biológico, desde julio a febrero. En este Capítulo se evaluó la calidad de la proteína según el estadio en el que se encontraban los 
ejemplares. Se incluyeron observaciones de "drip", capacidad de retención de agua, desnaturalización proteica medida por calorimetría diferencial de barrido y observación de la microestructura por microscopia electrónica de barrido, durante el almacenamiento congelado a $-25^{\circ} \mathrm{C}$.

En el Capítulo 5, se analizan los cambios que se producen durante el almacenamiento congelado en el desmenuzado de saraca debido al contenido lipídico del tejido muscular en dos estadios biológicos previo al desove y al concluirlo. En este Capítulo se estudió la incorporación de diversos antioxidantes a fin de evitar la oxidación de los lípidos durante el almacenamiento congelado (6 meses a $-25^{\circ} \mathrm{C}$ ). Se evaluó el uso de antioxidantes naturales frente a sintéticos. Se determinaron las sustancias reactivas al ácido tiobarbitúrico y se evaluaron los cambios en el color.

En el Capítulo 6, aborda el estudió de la calidad higiénico-sanitaria del desmenuzado de saraca de dos estadios biológicos (previo al desove y al concluirlo). Se evaluó la formación de metabolitos del nitrógeno básico volátil total y la carga microbiana durante 6 meses de almacenamiento congelado a $-25^{\circ} \mathrm{C}$; se determinó histamina en músculo y recuentos de espinas. Además se analizó la presencia de parásitos en ejemplares enteros.

En el Capítulo 7, se estudian los temas relacionados al desarrollo de productos de pescado tales como los conformados (hamburguesas, palitos), su consumo nacional y mundial. Este Capítulo se encuentra dividido en dos ensayos principales. El ensayo A abarca el diseño de formulaciones de conformados de saraca con el agregado de diferentes antioxidantes y concentrados de suero de leche. Se estudió la efectividad de los compuestos para retardar la oxidación lipídica de las formulaciones crudas, durante el almacenamiento congelado. En el ensayo B se evaluaron formulaciones con y sin el agregado de un antioxidante natural y el uso de suero de leche con 40 o $80 \%$ de proteína. En esta etapa se estudiaron los parámetros de calidad del producto cocido y se relacionaron con las características iniciales de la materia prima. Se incluyeron observaciones de la composición centesimal, perfil de ácidos grasos, rendimiento de la cocción, reducción del tamaño, retención de humedad y lípidos, jugosidad, análisis del perfil de textura y color. También se evaluó la aceptación de los consumidores y la calidad microbiológica de los productos.

El Capítulo 8 comprende las conclusiones generales de este trabajo de Tesis tomando en cuenta los resultados presentados en los Capítulos anteriores. 


\section{CAPITULO I \\ INTRODUCCIÓN GENERAL}

\section{I.1. La pesca y consumo}

El Mar Argentino es un área de concentración de especies marinas particularmente valiosas, ya que se trata de un hábitat ideal para su reproducción y persistencia numérica. Se encuentra sobre la plataforma continental y posee bancos pesqueros muy importantes. La pesca se basa principalmente en la obtención de grandes volúmenes de pescado. Una de las principales especies es la merluza (Merluccius hubbsi), la que se destina a la producción de filete, la mayor parte se destina al mercado europeo y americano, y una menor proporción se destina al interno.

La producción pesquera argentina ha presentado una observable y conocida reducción en los volúmenes de captura en los últimos 15 años. En 1998, en los puertos nacionales, se desembarcaron 1.117.375 toneladas, mientras que para el año 2001 sólo se capturaron 878.139 toneladas, y en el último año 2011, se observó una reducción presentando desembarques de 725.648 toneladas. Esta reducción de los niveles de pescado capturados, se debe en parte a la sobre pesca que las principales especies comerciales sufrieron las últimas décadas. A su vez, en el Mar Argentino se encuentran muchas otras especies que no tienen valor comercial y luego de la captura se descartan, por lo que promover la utilización de estas especies es una opción a la hora de explotar el Mar Argentino de una manera más sostenible.

En el siguiente cuadro se observa la disminución y estancamiento que viene operándose en las capturas totales, principalmente de merluza.

Tabla I-1: Desembarques de capturas marítimas totales en los principales puertos de Argentina - Por especie y puerto- Año 2001

\begin{tabular}{|c|c|c|c|c|c|c|}
\hline $\begin{array}{c}\text { Especie / } \\
\text { Puerto }\end{array}$ & Mar del Plata & Madryn & S. Antonio E & Deseado & Ushuaia & TOTAL \\
\hline \multicolumn{7}{|c|}{ PESCADOS } \\
\hline Abadejo & 11713.9 & 2572.3 & 153.5 & 3182.2 & 561.4 & 19644.0 \\
\hline Anchoíta & 11615.2 & 0.2 & & 0.7 & & 12815.0 \\
\hline Caballa & 4593.4 & 3.8 & 4.5 & & & 4602.0 \\
\hline $\begin{array}{c}\text { Corvina } \\
\text { Blanca }\end{array}$ & 5667.2 & & & & & 6368.0 \\
\hline
\end{tabular}




\begin{tabular}{|c|c|c|c|c|c|c|}
\hline $\begin{array}{l}\text { Merluza } \\
\text { Hubbsi }\end{array}$ & 170387.1 & 47375.6 & 6805.8 & 3705.2 & 5.2 & 249462.0 \\
\hline $\begin{array}{c}\text { Merluza de } \\
\text { Cola }\end{array}$ & 57589.6 & 7514.7 & 76.9 & 12345.1 & 28217.5 & 111885.0 \\
\hline Pescadilla & 11373.6 & 0.4 & 5.3 & & & 11844.0 \\
\hline Polaca & 1011.5 & 689.0 & & 1575.0 & 50739.7 & 54311.0 \\
\hline Saraca & 203.6 & & & & & 225.2 \\
\hline SUBTOTAL & 334932.0 & 67619.0 & 7376.0 & 26080.0 & 89020.0 & 561675.0 \\
\hline \multicolumn{7}{|c|}{ CRUSTÁCEOS } \\
\hline Langostino & 198.3 & 24.415 .4 & & 25662.9 & & 78866.0 \\
\hline SUBTOTAL & 316.0 & 24416.0 & & 25672.0 & 182.0 & 79495.0 \\
\hline \multicolumn{7}{|c|}{ MOLUSCOS } \\
\hline $\begin{array}{c}\text { Calamar } \\
\text { Illex }\end{array}$ & 32183.3 & 92227.4 & 2953.4 & 50703.8 & 2.9 & 230272.0 \\
\hline Vieira & 5314.5 & & & & 54.9 & 5370.0 \\
\hline SUBTOTAL & 38083.0 & 92235.0 & 2953.0 & 50705.0 & 58.0 & 236933.0 \\
\hline TOTAL & 373331.0 & 184307.0 & 10329.0 & 102457.0 & 89260.0 & 878139.0 \\
\hline
\end{tabular}

Valores expresados en toneladas (tn). Fuente: MAGYP (2012)

Tabla I-2: Desembarques de capturas marítimas totales en los principales puertos de Argentina - Por especie y puerto (t) Año 2011

\begin{tabular}{|c|c|c|c|c|c|c|}
\hline Especie/Puerto & Mar del Plata & Madryn & S. Antonio E & Deseado & Ushuaia & TOTAL \\
\hline \multicolumn{7}{|l|}{ PESCADOS } \\
\hline Abadejo & 9191.8 & 5746.7 & 66.4 & 475.5 & 730.2 & 16269.0 \\
\hline Anchoíta & 20543.5 & & & & & 20759.5 \\
\hline Caballa & 27302.9 & 315.8 & 5.5 & 0.3 & 131.0 & 27835.4 \\
\hline Corvina blanca & 17327.0 & 0.4 & & 28.0 & & 20480.3 \\
\hline $\begin{array}{c}\text { Merluza } \mathrm{H} . \\
\text { Norte } 41^{\circ}\end{array}$ & 40347.8 & 1485.7 & 573.9 & 145.8 & & 43296.9 \\
\hline $\begin{array}{c}\text { Merluza H. Sur } \\
41^{\circ}\end{array}$ & 142148.8 & 44041.6 & 11437.1 & 6352.6 & 9261.5 & 243300.7 \\
\hline Merluza de cola & 15606.4 & 15143.2 & 0.1 & & 39306.8 & 70647.1 \\
\hline Pescadilla & 12648.3 & 1.1 & & 2.8 & & 13185.7 \\
\hline Polaca & 271.0 & 81.5 & & & 3163.9 & 3518.0 \\
\hline Saraca & 46.0 & & & & & 77.5 \\
\hline Rayas nep & 18131.6 & 774.3 & 12.8 & 19.8 & 234.1 & 20288.0 \\
\hline SUBTOTAL & 351241.9 & 81444.3 & 12543.9 & 8164.0 & 60359.4 & 555614.3 \\
\hline \multicolumn{7}{|l|}{ CRUSTÁCEOS } \\
\hline Langostino & 1290.2 & 20652.0 & & 27347.7 & & 82764.0 \\
\hline SUBTOTAL & 1362.5 & 20887.1 & & 28765.4 & & 86200.6 \\
\hline
\end{tabular}




\begin{tabular}{|c|c|c|c|c|c|c|}
\hline \multicolumn{1}{|l|}{ MOLUSCOS } \\
\hline Calamar Illex & 44337.2 & 18324.0 & 75.6 & 12018.6 & 1014.0 & 76760.1 \\
\hline Vieira (callos) & 4852.3 & & & & 1848.6 & 6700.9 \\
\hline SUBTOTAL & 49383.2 & 18419.7 & 12619.5 & 12018.6 & 2862.6 & 83833.2 \\
\hline TOTAL & 401987.6 & 120751.1 & 401987.6 & 48948.0 & 63222.0 & 725648.1 \\
\hline
\end{tabular}

Valores expresados en toneladas (tn). Fuente: MAGYP (2012)

En las Tablas I-1 y l-2 se presentan las capturas en los principales puertos del país. El total esta referido a la totalidad de los puertos incluyendo lo ingresado en los puertos chicos. En el caso particular de la saraca, las capturas totales registradas por MAGYP (2012) para esta especie reflejan valores de captura total de 225.2 th y 77.5 tn para el 2001 y 2011 respectivamente. La diferencia con los valores de las Tablas I-1 y I-2 para la saraca, está dada porque gran parte de las capturas de esta especie llegan a puertos poco importantes o son desembarcados en la costa por la flota de rada y rio.

La importancia del pescado como alimento ha crecido en forma notable en los últimos decenios, a nivel mundial, debido a la toma de conciencia de los consumidores sobre la importancia de una alimentación sana orientada fuertemente a productos saludables. En 1994, el consumo mundial promedio de pescado per cápita fue de 13kg (FAO, 1996) y para el 2009 alcanzó los 18.4 kg (FAO, 2011). En nuestro país, se alcanzó en el 2001 un pico de consumo de $10.03 \mathrm{~kg}$ de pescado por persona por año, el cual continúa en los mismos niveles en la actualidad (Bertolotti, 2010). El puerto de Mar del Plata es el principal proveedor de productos pesqueros con destino al mercado interno aportando el $82 \%$ a la oferta total del país de productos procesados en tierra. Anualmente se envían desde el puerto de Mar del Plata al mercado interno más de 190 productos enfriados. Los productos congelados presentan una participación minoritaria dentro de las ventas al mercado interno (13\%, año 2008) lo cual se interpreta como un comportamiento poco dinámico del rubro (Bertolotti, 2010). Esta diferencia está directamente relacionada con la preferencia de la población por los productos frescos, cualquiera sea su nivel de ingreso, y en el cambio de la composición de la dieta alimenticia en los últimos años, donde la carne vacuna cedió su participación a la de pollo, pescado y cordero debido a la tendencia de tener una dieta más "sana y equilibrada", con mayor énfasis en los valores nutritivos y la frescura de los alimentos en contraposición a su contenido en grasa saturada y colesterol. El concepto de "sano" para el pescado presenta diferencias etarias, mostrando dos dimensiones de la noción de salud, por un lado nutritivo/vitaminas aspecto privilegiado por los jóvenes y por otro sano/no-graso, atributo valorado por los mayores (Errazti y col., 2004). 


\section{I.1.1. Clasificación de las especies pesqueras}

Una de las características más notables de los productos pesqueros es el gran número de especies en explotación y la gran diversidad que presentan entre sí. En una gran clasificación, se los puede dividir de agua dulce o marinos. Según el ambiente donde se distribuyan, presentarán algunas diferencias en su composición química y bioquímica, debidas en gran parte a las variaciones en la alimentación. En este trabajo de tesis abordaremos las clasificaciones y características particulares de las especies marinas de agua fría.

En una clasificación más biológica se los puede dividir por la estructura del esqueleto, en TELEOSTOS o ELASMOBRANQUIOS.

- TELEOSTOS, son las especies de pescado que presentan un esqueleto óseo. Incluida en esta clasificación se encuentran las principales familias de interés industrial, por ejemplo: Gadidae (Bacalao, merluza, polaca), Clupeidae (sardinela, sardina, arenque), Engraulidae (anchoíta, anchoveta) y Thunidae (todas las clases de atunes).

- ELASMOBRANQUIOS, son las especies de pescado que presentan un esqueleto cartilaginoso, también se lo define bajo el nombre de especies de la familia de los "CONDICTRIOS". Son conocidos dentro de esta clasificación, los tiburones y las rayas.

A su vez los teleósteos se dividen según su distribución en la columna de agua. De esta manera tenemos a los pelágicos, que se ubican desde media agua a la superficie, y los demersales que habitan en la profundidad del mar. En una clasificación más tecnológica, relacionada a su composición química, los pescados se pueden clasificar según su contenido en lípidos en magros, semi grasos y grasos. Los peces magros, generalmente gran parte de las especies demersales (bacalao, merluza, etc.), presentan un contenido entre el 0,1 y $2 \%$ de grasa en el músculo Otras especies demersales y las mayoría de las especies pelágicas (sardina, caballa, arenque, etc.), peces grasos, presentan altos contenido de lípidos mayores al 10\% en el músculo. Mientras que las especies semigrasas tienen un contenido de lípidos que puede variar entre 2 y $10 \%$ como es el caso del salmón entre otras especies.

Las especies pelágicas como el arenque (Clupea harengus) y la caballa (Scomber scombrus) pueden superar el $25 \%$ de lípidos totales en músculo dependiendo de la variación estacional de su ciclo biológico (Contreras-Guzman, 
2002). El cuerpo de este tipo de especies está adaptado para desarrollar grandes velocidades ya sea para la búsqueda de alimentos o durante las migraciones para desovar; se movilizan en cardúmenes que son capturados por distintas flotas pesqueras en diferentes partes del mundo. Las especies pelágicas son de gran importancia tecnológica en la industria pesquera dado que son las que se utilizan para la elaboración de una gran variedad de productos que va desde las conservas y preservas a la harina y aceite de pescado. En la Tabla I-3 se presenta la composición proximal de algunas de las especies marinas que se capturan en el Mar Argentino.

Tabla I.3: Composición química de algunas especies comerciales.

\begin{tabular}{|c|c|c|c|c|c|}
\hline Especie & Nombre científico & $\begin{array}{c}\text { proteína } \\
\%\end{array}$ & $\begin{array}{c}\text { lípidos } \\
\%\end{array}$ & $\begin{array}{c}\text { humedad } \\
\%\end{array}$ & $\begin{array}{c}\text { cenizas } \\
\%\end{array}$ \\
\hline \multirow[t]{2}{*}{ Anchoita } & Engraulis anchoita & 18,73 & 10,93 & 68,30 & 1,45 \\
\hline & & 18,70 & 5,2 & 74,20 & - \\
\hline \multirow[t]{2}{*}{ Abadejo } & Genipterus blacodes & 15,72 & 0,82 & 82,02 & 1,20 \\
\hline & & 15,81 & 0,86 & 81,94 & 1,21 \\
\hline Bonito & Sarda sarda & 23,20 & 5,50 & 70,70 & 1,50 \\
\hline Brótola & Urophysis brasiliensis & 18,34 & 1,50 & 80,43 & 1,12 \\
\hline \multirow[t]{2}{*}{ Caballa } & Scomberjaponicus & 21,90 & 13,93 & 61,88 & 1,38 \\
\hline & & 22,03 & 15,30 & 60,70 & 1,40 \\
\hline Calamar & Illex argentinus & 18,77 & 1,50 & 77,66 & 1,81 \\
\hline Castañeta & Cheilodactylus bergi & 16,99 & 11,10 & 67,40 & 3,96 \\
\hline Cazón & Galeorhinus glaus & 28,30 & 0,20 & 72,70 & 1,40 \\
\hline \multirow[t]{3}{*}{ Corvina } & Micropogon undulatus & 20,49 & 0,54 & 77,29 & 1,15 \\
\hline & Micropogonopercularis & 16,45 & 1,88 & 78,12 & 2,06 \\
\hline & Micropogonias furnieri & 19,20 & 0,80 & 79,23 & 1,34 \\
\hline Corvina negra & Pogonias cromis & 17,93 & 0,11 & 79,57 & 1,12 \\
\hline Gatuzo & Mustelus schmitti & 17,44 & 0,20 & 81,70 & 0,57 \\
\hline Lenguado & Paralichthys brasiliensis & 17,13 & 1,51 & 75,00 & 4,74 \\
\hline Lacha & Brevoortia aurea & 19,29 & 10,65 & 68,81 & 1,25 \\
\hline Lisa & Mugilbrasiliensis & 21,46 & 8,35 & 68,77 & 1,42 \\
\hline \multirow[t]{2}{*}{ Merluza } & Merluccius hubbsi & 16,45 & 1,88 & 78,12 & 2,07 \\
\hline & & 17,14 & 1,29 & 80,23 & 1,24 \\
\hline \multirow[t]{3}{*}{ Pescadilla } & Cynoscion striatus & 16,62 & 0,25 & 81,38 & 1,10 \\
\hline & & 15,95 & 1,87 & 73,36 & 6,42 \\
\hline & & 18,67 & 1,82 & 78,38 & 1,11 \\
\hline Sardina fueguina & Cuplea fuegensis & 14,00 & 8,90 & 70,20 & - \\
\hline
\end{tabular}

\section{I.1.2. Músculo de pescado}

En las especies con tejido óseo (Figura I-1, Izquierda), el músculo de pescado se compone químicamente de proteínas, agua, lípidos y cenizas. Generalmente no se 
incluyen los hidratos de carbono dentro de la composición proximal ya que las carnes de pescado presentan valores mínimos; sin embargo, es importante en los mariscos. En los pescados son valores muy bajos ya que durante la captura los individuos gastan su glucógeno de reserva, reduciendo aún más su contenido. La composición química varía significativamente entre las diferentes especies, y dentro de cada especie, a su vez, varía según la edad, el sexo, el desarrollo de las gónadas, la estación de año y la fase migratoria. Además, en cada individuo presenta variaciones en sus características fisiológicas y bioquímicas según la zona del cuerpo (lomo, cola, vientre) y clase de músculo (claro, oscuro) que se considere.
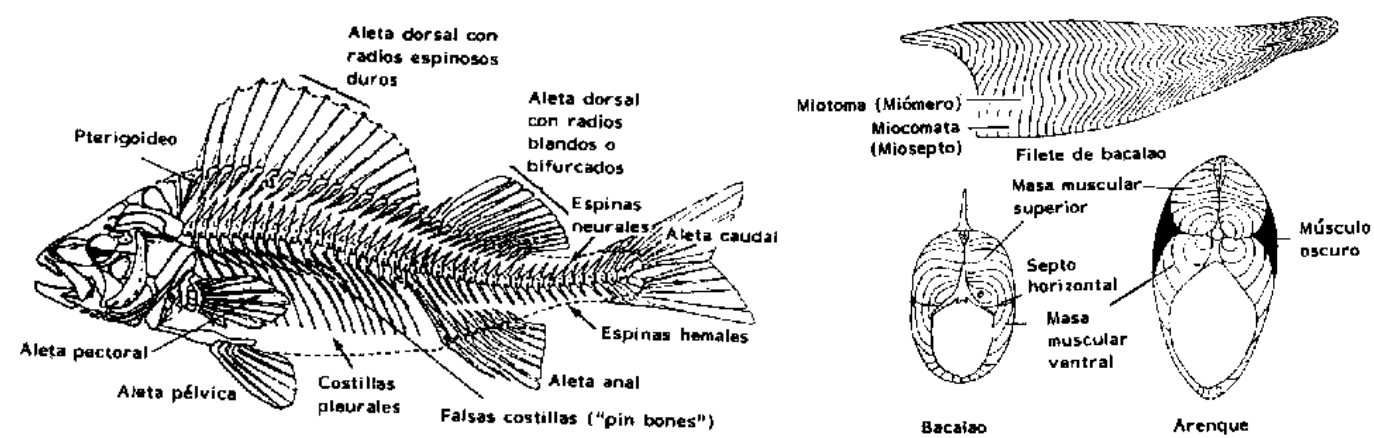

Figura I-1: Izquierda: Esqueleto - Derecha: Musculatura del Pez

Básicamente la estructura muscular del pescado consiste en dos paquetes musculares sobre cada lado de la columna vertebral y cada uno de ellos nuevamente dividido en una masa muscular superior ubicada por encima del septo horizontal axial y en una masa muscular ventral ubicada por debajo de este septo (Huss, 1988). Si bien la anatomía del músculo de pescado es muy simple presenta diferencias en la composición química en las diferentes secciones del músculo.

La masa muscular oscura se caracteriza por ser una delgada línea que corre lateralmente a lo largo del pez. Se ubica entre el músculo claro y la piel. El porcentaje de músculo oscuro varía según la especie (Figura I-2). En especies magras como el bacalao alcanza un $5 \%$ (Figura l-1) del músculo. En el caso de las especies pelágicas como el arenque que realizan grandes migraciones (Figura I-1) puede alcanzar hasta un $48 \%$ del músculo. El músculo oscuro presenta un mayor contenido de lípidos y de mioglobina que el músculo claro, lo que es requerido por las especies pelágicas para alcanzar máximas velocidades.

El músculo esquelético está constituido por células multinucleadas, largas y angostas denominadas fibras. Su longitud se encuentra en el orden de los centímetros mientras que su diámetro oscila entre 10 y $100 \mu \mathrm{m}$. Se distribuyen en segmentos de 
fibras musculares llamados miotomas y están separados por tabiques de tejido conectivo llamado mioseptos (Figura l-1, derecha). Los miotomas se caracterizan por presentar forma de $\mathrm{W}$ y se distribuyen a lo largo de la columna vertebral.

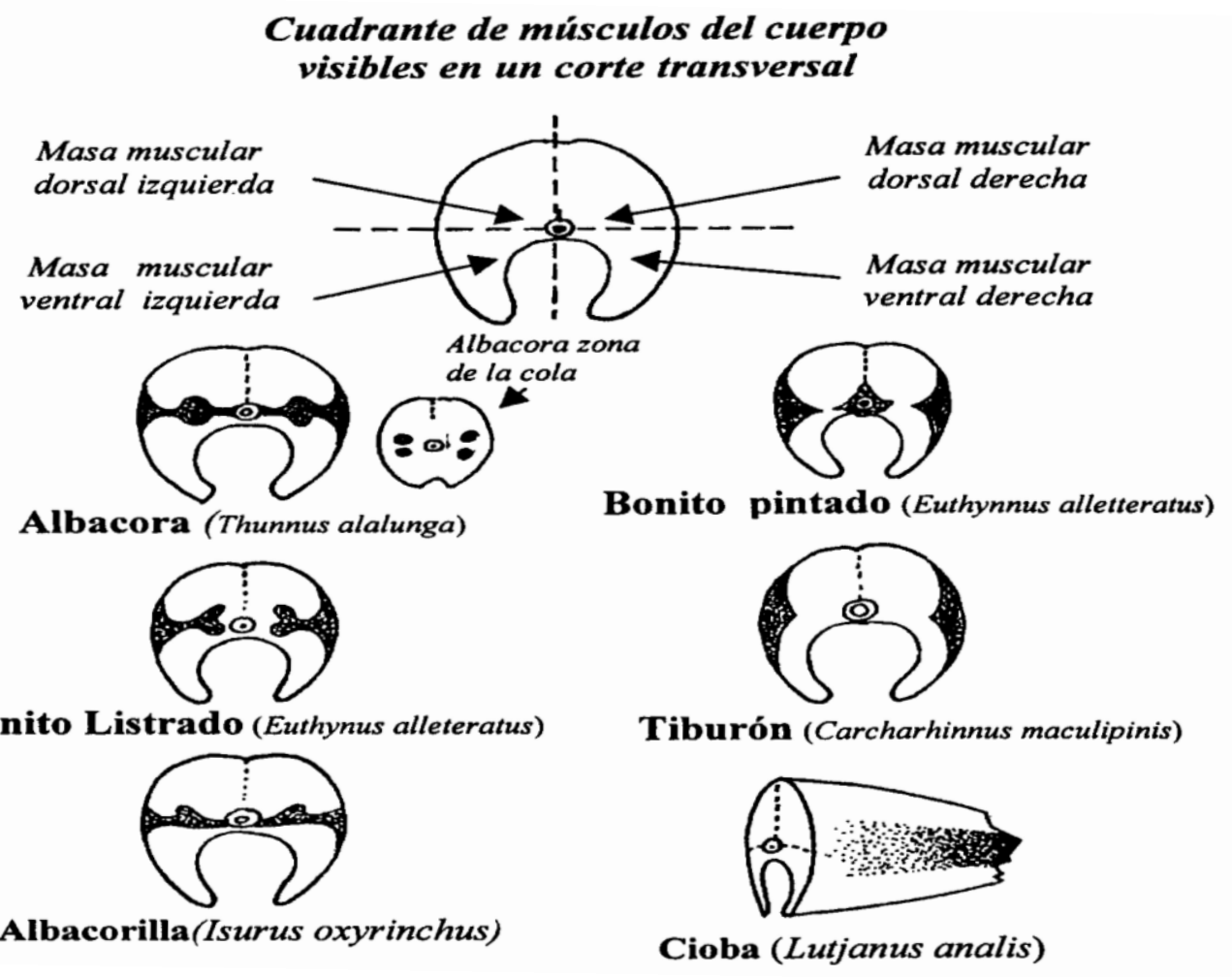

Figura I-2: Macroestructura de los músculos de especies pelágicas de importancia comercial, mostrando la estructura que asume el músculo oscuro. Contreras-Guzman, (2002)

\section{I.1.3. Ciclo Biológico}

Los peces como la mayoría de las especies presentan un periodo de desarrollo hasta alcanzar la o las etapas de reproducción. Para ello requiere la utilización de energía. En una primera etapa los individuos juveniles utilizan la energía adquirida para el crecimiento y la supervivencia. Al alcanzar la madurez, la cual varía y depende de cada especie, destina esta energía a los diversos procesos reproductivos. Para maximizar el éxito reproductivo, un individuo debe repartir sus recursos energéticos adecuadamente y además, debe procurar que su descendencia nazca en las condiciones medio ambientales adecuadas. Por lo tanto la estacionalidad con que se produce la puesta es de vital importancia para el futuro desarrollo y supervivencia de la descendencia (Saborido-Rey, 2008).

La edad de la primera maduración se define como la edad a la cual un individuo se reproduce por primera vez. Esto está muy asociado con la talla del individuo en el 
momento de la primera maduración. Un aspecto interesante en la ecología de la reproducción es el hecho de que la edad y la talla de maduración pueden variar dentro de una misma especie. Hay especies, como es el caso del salmón y algunas variedades de anguilas que se reproducen una sola vez. En la mayoría de las especies esto no sucede y suelen presentar varios ciclos reproductivos a lo largo de su vida. Por otro lado en aquellas poblaciones fuertemente explotadas, los peces que demoran más en madurar, tienen menores posibilidades de sobrevivir para dejar herencia. Por el contrario, aquellos peces que maduran rápidamente podrían llegar a reproducirse antes de ser capturados.

El período de reproducción es estacional, esto se debe básicamente a que cada especie procura que el medio donde se producirá la descendencia sea el adecuado para desarrollarse. El entorno debe aportar alimento apropiado, protección de los predadores y unas condiciones abióticas favorables. A su vez las hembras deben llegar a la época de puesta con suficientes reservas energéticas. En el ciclo biológico característico de las especies pelágicas, el desarrollo de las gónadas comienza al finalizar el verano y se prolonga durante el invierno. Es en esta época en la cual los individuos se alimentan intensamente del plancton que se desarrolla durante el "bloom" de otoño. Una vez que los huevos alcanzan la madurez, las especies pelágicas comienzan su desove que abarca desde el final del invierno y durante la primavera. En estos casos las hembras generan una gran cantidad de huevos que los libera en tandas sucesivas, de esta manera el periodo de puesta se prolonga por varios meses. Esta es una estrategia ecológica para asegurar la progenie ya que de esta manera si algún desorden ambiental se suscitare, no estarían en riesgo todos los huevos desovados. Es característico de las especies pelágicas las migraciones hacia zonas de desove y que éstas no sean las adecuadas para la alimentación de los adultos. Es por ello que los individuos deben acumular energía de reserva para la época en que desoven ya que no dispondrán de suficiente alimento durante ese periodo, que como se comentó, puede llegar a extenderse por varios meses (Kozlova y Khotimchenko, 2000; Massa, Fernandez-Compaz y Pennisi Forell, 2012).

Se estima que el $75 \%$ de la energía en peces es digerida, esta energía neta tiene los siguientes destinos: metabolismo basal (26\%), metabolismo activo (16\%), crecimiento $(0-18 \%)$ y reproducción (0-18\%). Al comenzar la época de reproducción una mayor proporción de la energía disponible pasa a ser asignada a las tareas de reproducción. Tras el ciclo reproductivo la energía será utilizada para tres fines, supervivencia, crecimiento y reproducción posterior. Por lo general las especies que sobreviven a la primera maduración sexual destinan la energía sobrante a la reproducción y al crecimiento (Saborido-Rey, 2008). 


\section{I.2. Componentes funcionales en alimentos}

\section{I.2.1. Los alimentos funcionales}

El concepto actual de nutrición está evolucionando. La «nutrición adecuada», se entendía antiguamente como "suficiente", dirigida a evitar déficits de nutrientes, sin embargo, actualmente dejó de ser la meta en las sociedades desarrolladas. En las últimas décadas emergió el concepto de la alimentación como "nutrición óptima". Su objetivo está en la calidad de vida y el bienestar integral del individuo. La nutrición adquiere un nuevo enfoque terapéutico y preventivo; participa en la promoción de la salud y es ya considerada como factor de protección ante una larga serie de circunstancias patológicas (Silveira Rodriguez, Monereo Megías y Molina Baena, 2003).

En la última fase del siglo $X X$, se inició en Japón la comercialización de alimentos especialmente formulados para cumplir con una función de salud. A estos alimentos se les categorizó como FOSHU (Foods for Specified Health Uses) y marcaron el inicio de una nueva era en la industria alimentaria: la era de los Alimentos Funcionales. Este concepto ha sido acuñado para describir alimentos con ingredientes capaces de producir efectos saludables, cuya elaboración no sólo contempla su calidad nutricional, sensorial y tecnológica, sino que también aportan fitoquímicos $u$ otros agentes bioactivos que contribuyen al bienestar del consumidor. El concepto detrás del término es que su consumo está dirigido a mantener una condición de salud y/o reducir un riesgo de enfermedad, especialmente del tipo enfermedades crónicas no transmisibles (Lutz, 2009). De esta manera comenzaron a surgir los alimentos funcionales, que se definen como aquellos alimentos que brindan algún tipo de beneficio para la salud. Son alimentos procesados que contienen ingredientes que ayudan a funciones corporales específicas, además de ser nutritivos, deben ser:

- Alimentos manufacturados a partir de ingredientes naturales (no son una cápsula, polvo o tableta).

- Alimentos que deben consumirse como parte de la dieta diaria.

- Alimentos que cumplen un papel específico en las funciones del ser humano, incluyendo:

$\checkmark$ mejoramiento de los mecanismos de defensa biológica

$\checkmark$ prevención o recuperación del paciente de una enfermedad específica

$\checkmark$ control de las condiciones físicas y mentales

$\checkmark \quad$ retardo en el proceso de envejecimiento 
Los alimentos funcionales pueden tener un papel importante en la reducción de diversas enfermedades, debido a que pueden facilitar cambios en las dietas sin grandes esfuerzos ya que no influyen directamente en cambios de hábitos alimenticios (Shahidi, 2004).

\section{I.2.2. Lípidos presentes en los alimentos}

Se entiende por grasas alimentarías a todos los lípidos de los tejidos vegetales y animales que se ingieren con los alimentos. Son sustancias orgánicas, insolubles en agua y solubles en solventes orgánicos. Como se sabe, las grasas se diferencian de los aceites por el punto de fusión, las grasas son sólidas a temperatura ambiente mientras que los aceites son líquidos. Esto está relacionado con el mayor contenido de ácidos grasos insaturados presente en la composición de los aceites, y que en los peces de aguas frías, tiene la funcionalidad biológica de que los lípidos corporales no solidifiquen por las bajas temperaturas del ambiente.

Los lípidos son un grupo muy heterogéneo de moléculas que usualmente se clasifican de diversas maneras. Una clasificación los divide en dos grupos, dependiendo de que posean en su composición lípidos saponificables o lípidos no saponificables. Dentro de los lípidos saponificables se encuentran dos subgrupos, el de los lípidos simples, que son moléculas que solo contienen carbono, hidrógeno, oxígeno, y el de los lípidos complejos, que además de contener en sus moléculas carbono, hidrógeno y oxígeno, también contienen otros elementos como nitrógeno, fósforo, azufre u otra molécula como un glúcido (Tabla l-4). A los lípidos complejos se les denominan lípidos de membrana pues son los principales compuestos que forman las membranas celulares. Los lípidos presentes en los alimentos son, en su mayoría, mezclas de triglicéridos (compuestos por 3 ácidos graso unidos a un glicerol) y en menores cantidades están presentes los otros lípidos.

Los ácidos grasos son constituyentes importantes en la nutrición humana. Proporcionan 35 - $40 \%$ del valor calórico de la dieta en naciones industrializadas con alto nivel de vida, siendo un 10 - $15 \%$ menor en pueblos de bajos recursos (FAO, 1997). Aportan $9 \mathrm{kcal} / \mathrm{g}$ consumido, actúan como transportadores de vitaminas A, D, E y $\mathrm{K}$ y pro-vitaminas como los carotenos. En la alimentación de los recién nacidos son fundamentales, ya que aportan suficiente energía en un volumen reducido, correspondiente a la capacidad de sus estómagos. En los alimentos en general dan mayor saciedad, influyen en la textura, en la sensación de suavidad, palatabilidad y también en el sabor y el aroma. 
Tabla I.4: Lípidos, clasificación y estructura química

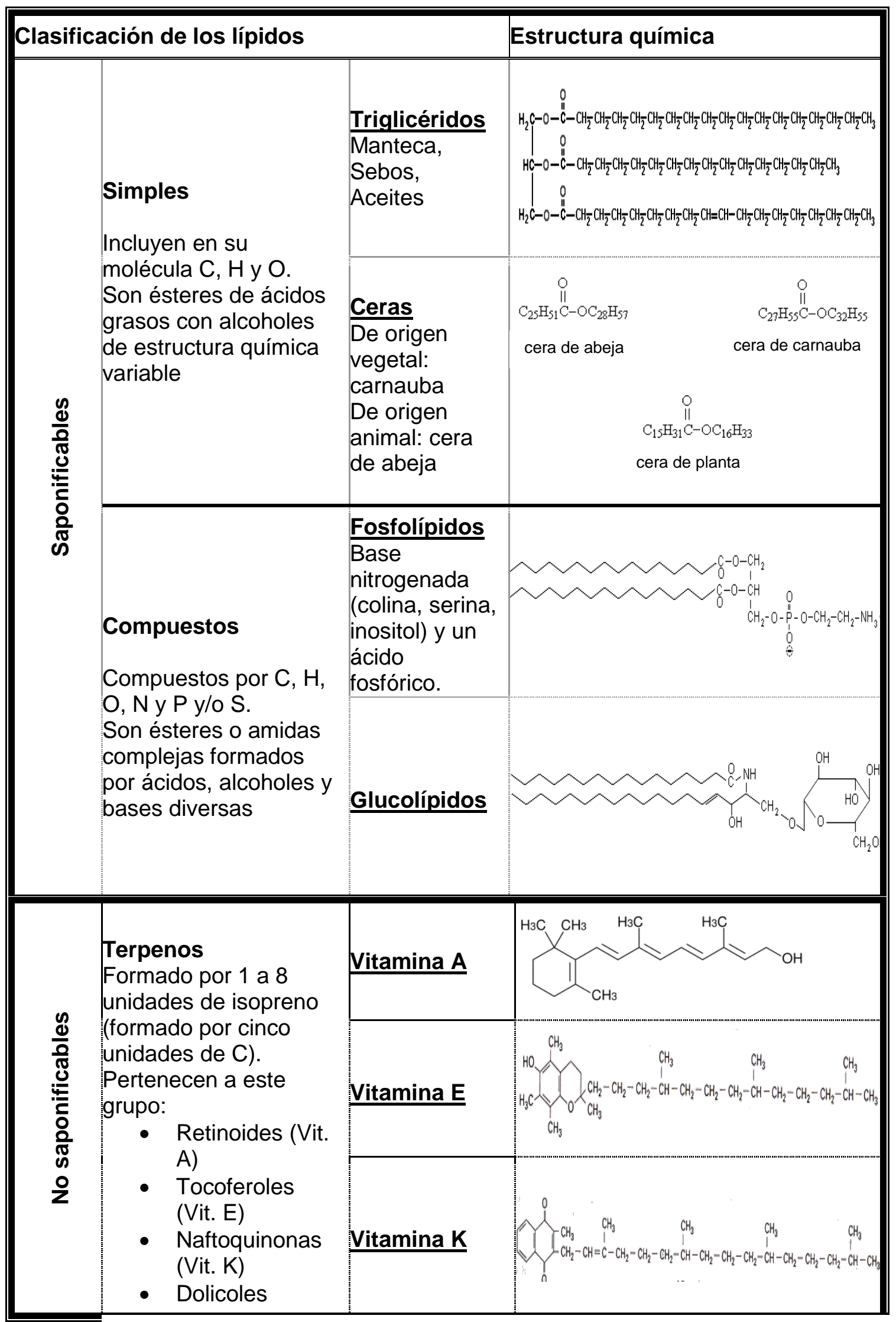




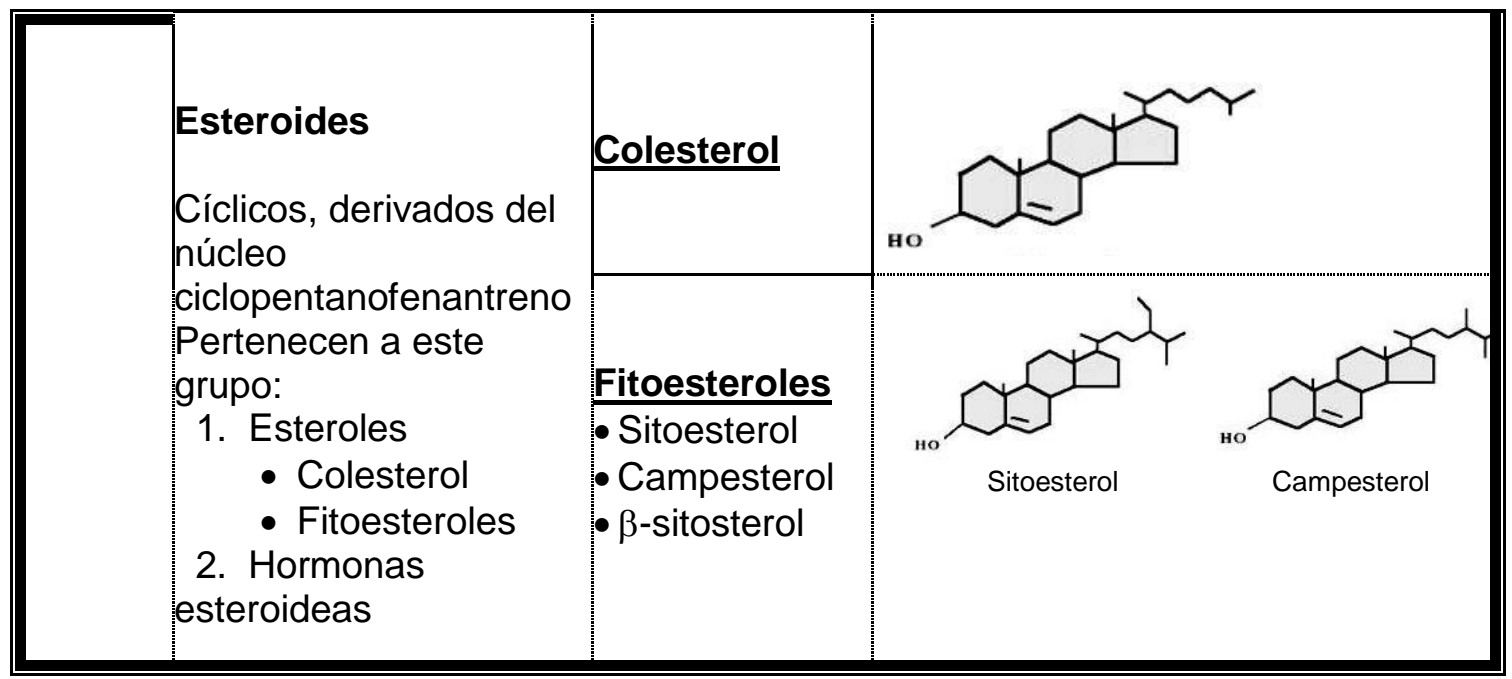

Los ácidos grasos son cadenas lineales con número par de átomos de carbono. El largo de la cadena varía entre 4 y 30 átomos de carbono. También se diferencian por la presencia de dobles enlaces y por la configuración cis o trans de los mismos. (Tabla I-5) (Fennema, 1996).

En los pescados la composición de los ácidos grasos está influenciada por diferentes factores tales como la familia biológica, las condiciones ambientales (salinidad, temperatura, época del año), la composición de ácidos grasos del alimento habitual y el estado de estrés fisiológico (ayuno, migración, desove). Existen importantes diferencias entre los ácidos grasos de los animales marinos y los de otros grupos de organismos. En los pescados existe una mayor diversidad en la longitud de las cadenas, contando desde 14 hasta 24 átomos de carbono. Pueden alcanzar a contener de 1 a 6 insaturaciones, generando un promedio de insaturación superior al de las grasas animales y los aceites vegetales. Presentan diversas formas isoméricas, generando las estructuras $n-3, n-4, n-5, n-6, n-7, n-9$ y otras. En los lípidos marinos predomina la estructura $n-3$ y en los peces de agua dulce la n-6. En los aceites de pescado han sido identificados más de 90 ácidos grasos, aunque no más de 20 exceden el $1 \%$ y solo 10 u 11 existen en cantidades suficientes para influir en las propiedades físicas o químicas de las grasas.

En la Tabla I-6, se presentan los perfiles de ácidos grasos de distintas especies marinas, 3 magras y 3 grasas. Los aceites marinos presentan una alta proporción de ácidos grasos poli-insaturados (PUFAs) n-3 y escasa cantidad de sus precursores de 18 carbonos (ácido linoleico y ácido linolénico) (Introzzi, 1995). Entre los PUFAs de la serie n-3 presentes en los lípidos de pescado se destacan: ácido eicosapentaenoico EPA (C20:5 n-3), ácido docosapentenoico DPA (C22:5 n-3) y ácido docosahexaenoico DHA (C22:6 n-3) (Tironi, 2005). 
Tabla I.5 : Nomenclatura de los principales ácidos grasos.

\begin{tabular}{|c|c|c|c|c|}
\hline & Nombre común & Nombre sistemático & Abreviatura & $\begin{array}{l}\text { Familia de } \\
\text { ácido graso }\end{array}$ \\
\hline \multirow{8}{*}{ 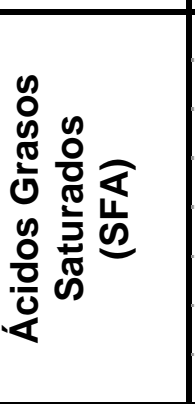 } & Cáprico & Decanoico & $10: 0$ & \\
\hline & Láurico & Dodecanoico & 12:0 & \\
\hline & "Mirístico & Tetradecanoico & 14:0 & \\
\hline & Palmítico & Hexadecanoico & $16: 0$ & \\
\hline & Esteárico & octadecanoico & 18:0 & \\
\hline & Araquídico & Eicosanoico & $20: 0$ & \\
\hline & Behénico & Docosanoico & 22:0 & \\
\hline & Lignocérico & Tetracosanoico & $24: 0$ & \\
\hline \multirow{6}{*}{ 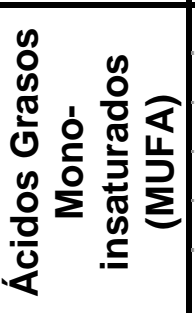 } & Palmitoleico & 9-hexadecenoico & $16: 1$ & $n-7$ \\
\hline & Oleico & 9-octadecenoico & $18: 1$ & $n-9$ \\
\hline & Gadoleico & 11-eicosaenoico & $20: 1$ & $n-9$ \\
\hline & Cetoleico & 11-docasaenoico & $22: 1$ & $n-11$ \\
\hline & Erúcico & 13-docasaenoico & $22: 1$ & $n-9$ \\
\hline & Nervónico & 15-tetracosaenoico & $24: 1$ & $n-9$ \\
\hline \multirow{11}{*}{ 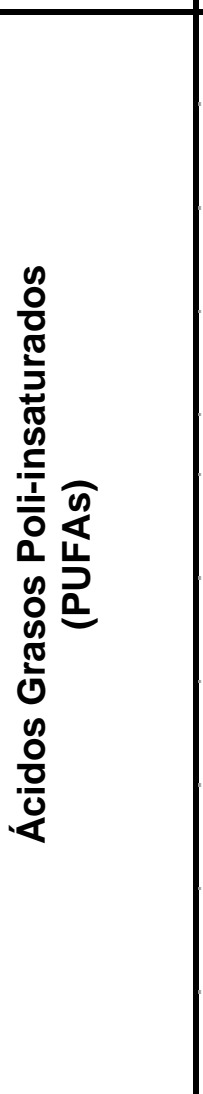 } & Linoleico (LA) & $\begin{array}{c}9,12- \\
\text { octadecadienoico }\end{array}$ & $18: 2$ & $n-6$ \\
\hline & $\alpha$-linolénico (ALA) & $\begin{array}{c}9,12,15- \\
\text { octadecatrienoico }\end{array}$ & $18: 3$ & $n-3$ \\
\hline & Y -linolénico (GLA) & $\begin{array}{c}6,9,12- \\
\text { octadecatrienoico }\end{array}$ & $18: 3$ & $n-6$ \\
\hline & dihomo- $\mathrm{y}$-linolénico & $\begin{array}{c}8,11,14- \\
\text { eicosatrienoico }\end{array}$ & $20: 3$ & $n-6$ \\
\hline & & 5,8,11-eicosatrienoico & $20: 3$ & $n-9$ \\
\hline & Araquidónico (ARA) & $\begin{array}{c}5,8,11,14- \\
\text { eicosatetraenoico }\end{array}$ & $20: 4$ & $n-6$ \\
\hline & EPA & $\begin{array}{c}5,8,11,14,17- \\
\text { eicosapentaenoico }\end{array}$ & $20: 5$ & $n-3$ \\
\hline & Adrénico & $\begin{array}{c}7,10,13,16- \\
\text { docosatetraenoico }\end{array}$ & $22: 4$ & $n-6$ \\
\hline & & $\begin{array}{c}7,10,13,16,19- \\
\text { docosapentaenoico }\end{array}$ & $22: 5$ & $n-3$ \\
\hline & ADP & $\begin{array}{c}4,7,10,13,16- \\
\text { docosapentaenoico }\end{array}$ & $22: 5$ & $n-6$ \\
\hline & $\mathrm{DHA}$ & $\begin{array}{c}4,7,10,13,16,19- \\
\text { docosahexaenoico }\end{array}$ & $22: 6$ & $n-3$ \\
\hline
\end{tabular}


Tabla I.6: Composición de ácidos grasos (\% en peso total de ácidos grasos) de lípidos totales*. (Huynh y Kitts, 2009).

\begin{tabular}{|c|c|c|c|c|c|c|}
\hline \multirow[b]{2}{*}{$\begin{array}{l}\text { Ácidos } \\
\text { Grasos }\end{array}$} & \multicolumn{2}{|c|}{ Especies Magras } & \multicolumn{4}{|c|}{ Especies Grasas } \\
\hline & Merluza & Abadejo & Capelán & Sardina & $\begin{array}{l}\text { Salmon } \\
\text { Rosado }\end{array}$ & Arenque \\
\hline C14:0 & $1.06 \pm 0.49$ & $1.84 \pm 0.37$ & $6.37 \pm 0.50$ & $3.66 \pm 1.22$ & $3.53 \pm 0.56$ & $3.99 \pm 0.48$ \\
\hline C16:0 & $21.70 \pm 1.95$ & $14.96 \pm 1.45$ & $10.59 \pm 1.11$ & $15.85 \pm 2.80$ & $14.78 \pm 0.73$ & $18.35 \pm 1.08$ \\
\hline C17:0 & $1.08 \pm 0.22$ & $0.44 \pm 0.02$ & $0.45 \pm 0.10$ & $0.78 \pm 0.43$ & $0.83 \pm 0.47$ & $0.74 \pm 0.26$ \\
\hline C18:0 & $7.18 \pm 1.08$ & $4.02 \pm 0.81$ & $1.06 \pm 0.17$ & $3.95 \pm 0.46$ & $3.19 \pm 0.13$ & $2.55 \pm 0.33$ \\
\hline Total SFA & $32.40 \pm 2.97^{a}$ & $21.57 \pm 1.22^{c}$ & $19.31 \pm 1.08^{d}$ & $25.20 \pm 4.17^{b}$ & $23.07 \pm 1.05^{\mathrm{c}}$ & $26.21 \pm 1.25^{b}$ \\
\hline C16:1n-11 & $0.22 \pm 0.19$ & $0.26 \pm 0.14$ & $0.31 \pm 0.07$ & $0.60 \pm 0.16$ & $0.38 \pm 0.05$ & $0.28 \pm 0.05$ \\
\hline C16:1n-9 & $0.62 \pm 0.54$ & $0.11 \pm 0.06$ & $0.26 \pm 0.03$ & $0.29 \pm 0.11$ & $0.30 \pm 0.05$ & $0.15 \pm 0.02$ \\
\hline C16:1n-7 & $2.53 \pm 0.63$ & $1.88 \pm 0.31$ & $9.88 \pm 1.12$ & $2.84 \pm 0.49$ & $4.09 \pm 0.43$ & $6.03 \pm 0.78$ \\
\hline C17:1 & $0.30 \pm 0.09$ & $0.15 \pm 0.13$ & $0.78 \pm 0.13$ & $0.06 \pm 0.09$ & $0.08 \pm 0.03$ & $0.84 \pm 0.08$ \\
\hline C18:1n-11 & $0.18 \pm 0.08$ & $1.51 \pm 0.28$ & $0.59 \pm 0.05$ & $0.27 \pm 0.98$ & $0.99 \pm 0.15$ & $0.13 \pm 0.08$ \\
\hline C18:1n-9 & $9.65 \pm 0.28$ & $7.18 \pm 1.26$ & $4.97 \pm 0.65$ & $4.16 \pm 0.29$ & $11.26 \pm 1.14$ & $23.78 \pm 4.70$ \\
\hline C18:1n-7 & $4.55 \pm 0.55$ & $3.02 \pm 0.21$ & $1.94 \pm 0.29$ & $1.96 \pm 0.27$ & $3.19 \pm 0.20$ & $3.42 \pm 0.41$ \\
\hline C18-1n-5 & $0.13 \pm 0.04$ & $0.40 \pm 0.06$ & $0.59 \pm 0.06$ & $0.18 \pm 0.09$ & $0.58 \pm 0.11$ & $0.28 \pm 0.05$ \\
\hline$C 20: 1 n-11$ & $0.51 \pm 0.22$ & $3.74 \pm 1.19$ & $0.35 \pm 0.18$ & $1.27 \pm 0.14$ & $3.98 \pm 0.71$ & $0.38 \pm 0.23$ \\
\hline C20:1n-9 & $0.83 \pm 0.28$ & $4.06 \pm 1.29$ & $15.50 \pm 1.45$ & $0.97 \pm 0.45$ & $2.14 \pm 0.39$ & $5.20 \pm 1.31$ \\
\hline C22:1n-11 & $0.44 \pm 0.20$ & $4.15 \pm 0.27$ & $14.36 \pm 1.15$ & $1.09 \pm 0.61$ & $5.65 \pm 0.87$ & $6.37 \pm 1.77$ \\
\hline C22:1n-9 & $0.19 \pm 0.06$ & $0.51 \pm 0.15$ & $2.13 \pm 0.42$ & $0.21 \pm 0.07$ & $0.75 \pm 0.0$ & $0.30 \pm 0.17$ \\
\hline Total MUFA & $21.88 \pm 1.99^{d}$ & $27.68 \pm 2.48^{b c}$ & $52.86 \pm 2.32^{a}$ & $14.21 \pm 1.75^{\mathrm{e}}$ & $34.99 \pm 2.22^{b}$ & $48.12 \pm 2.57^{\circ}$ \\
\hline C16:2n-6 & $0.13 \pm 0.04$ & $0.14 \pm 0.06$ & $0.16 \pm 0.05$ & $0.36 \pm 0.11$ & $0.25 \pm 0.03$ & $0.17 \pm 0.03$ \\
\hline C16:2n-4 & $0.47 \pm 0.13$ & $0.14 \pm 0.04$ & $0.14 \pm 0.07$ & $0.46 \pm 0.15$ & $0.21 \pm 0.04$ & $0.21 \pm 0.02$ \\
\hline C16:3n-6 & $0.34 \pm 0.13$ & $0.12 \pm 0.05$ & $0.46 \pm 0.09$ & $0.26 \pm 0.15$ & $0.48 \pm 0.06$ & $0.61 \pm 0.09$ \\
\hline C18:2n-6 & $0.92 \pm 0.21$ & $0.85 \pm 0.25$ & $1.18 \pm 0.17$ & $1.49 \pm 0.13$ & $1.49 \pm 0.15$ & $0.99 \pm 0.22$ \\
\hline C18:3n-6 & $0.15 \pm 0.04$ & $0.15 \pm 0.05$ & $0.42 \pm 0.09$ & $0.17 \pm 0.12$ & $0.08 \pm 0.02$ & $0.19 \pm 0.06$ \\
\hline C18:3n-3 & $0.30 \pm 0.15$ & $0.29 \pm 0.10$ & $0.27 \pm 0.04$ & $0.93 \pm 0.16$ & $1.17 \pm 0.16$ & $0.41 \pm 0.08$ \\
\hline C18:4n-3 & $0.43 \pm 0.24$ & $0.59 \pm 0.26$ & $0.76 \pm 0.08$ & $2.32 \pm 0.24$ & $1.51 \pm 0.11$ & $1.03 \pm 0.23$ \\
\hline$C 20: 2 n-6$ & $0.32 \pm 0.28$ & $0.12 \pm 0.03$ & $0.57 \pm 0.05$ & $0.46 \pm 0.15$ & $0.33 \pm 0.06$ & $0.19 \pm 0.12$ \\
\hline$C 20: 4 n-6$ & $1.95 \pm 0.33$ & $0.78 \pm 0.09$ & $0.50 \pm 0.12$ & $1.02 \pm 0.33$ & $0.60 \pm 0.09$ & $0.64 \pm 0.12$ \\
\hline C20:4n-3 & $0.36 \pm 0.04$ & $0.35 \pm 0.07$ & $0.63 \pm 0.07$ & $0.86 \pm 0.19$ & $1.13 \pm 0.07$ & $0.36 \pm 0.10$ \\
\hline C20:5n-3 & $12.91 \pm 1.51$ & $12.37 \pm 0.69$ & $7.85 \pm 0.67$ & $11.43 \pm 1.08$ & $8.17 \pm 0.78$ & $8.74 \pm 0.88$ \\
\hline C21:5n-3 & $0.49 \pm 0.21$ & $0.34 \pm 0.1$ & $0.46 \pm 0.04$ & $0.40 \pm 0.06$ & $0.34 \pm 0.05$ & $0.35 \pm 0.03$ \\
\hline C22:5n-3 & $1.25 \pm 0.09$ & $1.58 \pm 0.19$ & $0.97 \pm 0.14$ & $2.01 \pm 0.38$ & $3.19 \pm 0.09$ & $0.78 \pm 0.08$ \\
\hline C22:6n-3 & $22.08 \pm 1.28$ & $28.98 \pm 1.73$ & $9.95 \pm 0.30$ & $32.65 \pm 3.44$ & $19.34 \pm 1.11$ & $8.58 \pm 1.55$ \\
\hline Total PUFA & $43.46 \pm 1.52^{c}$ & $47.57 \pm 2.06^{b}$ & $24.56 \pm 2.16^{\mathrm{e}}$ & $56.81 \pm 3.64^{a}$ & $38.89 \pm 2.02^{d}$ & $24.21 \pm 2.62^{\epsilon}$ \\
\hline n-3 PUFA & $38.41 \pm 1.12^{c}$ & $44.89 \pm 1.80^{b}$ & $20.90 \pm 1.89^{b}$ & $51.21 \pm 3.58^{a}$ & $35.03 \pm 1.89^{d}$ & $20.59 \pm 2.25^{b}$ \\
\hline
\end{tabular}


*Los resultados se presentan media \pm desviación standart $(n=8)$. ** Supraíndices diferentes entre las filas de especies magras y entre las filas de especies grasas indican diferencias significativas entre los grupos de especies $(p<0.05)$.

\section{I.2.3. Consumo de ácidos grasos n- 3 en la dieta}

La importancia y por ende, el incremento del consumo de pescado a nivel mundial está asociado a los descubrimientos sobre la importancia nutricional de sus componentes. Esto produjo notables modificaciones en los hábitos de consumo de amplios sectores de la población, que considera al pescado como un alimento "sano". Según las recomendaciones de la Organización Mundial de la Salud (OMS, 2004) limitar el consumo de grasas, sustituir las grasas saturadas por grasas insaturadas y tratar de eliminar los ácidos grasos trans de la dieta, debe ser una tendencia que comienza en la infancia y debe continuar a lo largo de toda la vida. Para ello la población debe tener accesibilidad y disponibilidad de los alimentos sanos. La incorporación de dietas moderadas en grasa, pero ricas en ácidos grasos monoinsaturados (MUFAs) y poli-insaturados (PUFAs) generalmente disminuyen los niveles de colesterol de baja y muy baja densidad (LDL y VLDL) y triglicéridos en la sangre (IFIC, 2005), de esta manera se contribuye a atenuar el riesgo cardíaco. Por estas razones el consumo de pescado es una opción "sana", ya que los productos marinos son ricos en PUFA como ácido $\alpha$-linolénico (ALA), ácido eicosapentaenoico (EPA) y ácido docosahexaenoico (DHA), una fuente de proteínas de alto valor biológico, menor contenido de grasa que el resto de los productos de origen animal, y proveedores de vitaminas y fósforo.

El cuerpo humano puede sintetizar ácidos grasos saturados (SFA) y MUFA pero no todos los PUFAs de cadena larga (IFIC, 2005). Por esto, algunos PUFAs de cadena larga son reconocidos como ácidos grasos esenciales, y es necesario incorporarlos a través de la dieta. La falta de estos ácidos grasos durante un período de tiempo resulta en síntomas clínicos adversos (daños de crecimiento, lesiones cutáneas y anormalidades neurológicas). Hay dos subclases de PUFA de cadena larga: ácidos grasos n-3 (n-3) y ácidos grasos n-6 (n-6). Ejemplos de n-3 son: $\alpha-$ linolénico 18:3 (ALA), eicosapentaenoico 20:5 (EPA) y docosahexaenoico 22:6 (DHA) y de n-6 (n-6): ácido linoleico 18:2 (LA), ácido gamma-linoleico 20:3 (GLA) y ácido araquidónico 20:4 (ARA). 


\subsubsection{EPA, DHA y la salud}

El aumento del consumo de $\mathrm{n}-3$ ha sido asociado en numerosos estudios con efectos benéficos potenciales sobre la salud. Los notables avances en el estudio de la relación entre alimentación y patología humana han permitido un gran crecimiento en la prevención y el tratamiento de las enfermedades. Los PUFAs son componentes estructurales importantes de las membranas fosfolipídicas de los tejidos de todo el cuerpo y en especial, de la retina y el cerebro, desde la concepción, embarazo e infancia, e indudablemente, durante toda la vida (Connor, 2000). El ALA es esencial para los seres humanos y es el precursor de EPA y DHA, estos últimos constituyen precursores de moléculas activas importantes para el organismo.

EI EPA produce efectos:

- Hipotrigliceridémicos (a nivel del LDL y VLDL)

- Hipocolesterolémicos (aumento del flujo biliar y del transporte reverso de colesterol)

- Antiinflamatorios (formación de leucotrienos de la serie 5)

- Antitrombótico (formación eicosanoides de la serie 3)

- Hipotensor (permite la relajación de la musculatura vascular)

Su consumo se asocia con la prevención de las enfermedades cardiovasculares. En este sentido, estos ácidos grasos han mostrado que disminuyen la agregación plaquetaria y los fenómenos inflamatorios que agravan los cuadros de ateromatosis (De Caterina, 2011).

El DHA es un ácido graso esencial para el desarrollo y la función del sistema nervioso, por lo cual es muy importante en la etapa de gestación y de crecimiento (Valenzuela, Sanhueza y Nieto, 2002; Valenzuela y Sanhueza, 2009). Los beneficios de su consumo son:

Para la madre:

- Permite embarazos más prolongados.

- Disminuye la insulino resistencia y la diabetes gestacional.

- Disminuye el riesgo de depresión post-parto

Para el bebé:

- Mejora agudeza visual y percepción de los colores

- Mejora la capacidad de aprendizaje y de memorización

- Disminuye la incidencia de déficit atencional 
Algunos de los efectos más importantes de PUFAs se relacionan con su conversión enzimática en una serie de metabolitos oxigenados denominados eicosanoides. Dentro de los mismos se incluyen las prostaglandinas, tromboxanos, leucotrienos, hidroxiácidos y lipoxinas. Los eicosanoides se forman directamente a partir precursores como ARA-n6, GLA-n6 y EPA-n3 a partir de mecanismos enzimáticos o específicos. De cada ácido graso se genera una serie de prostanoides y leucotrienos con diferentes propiedades biológicas. La actividad fisiológica que desarrollan las prostaglandinas es controlar la agregación plaquetaria o la inhibición del efecto de la hormona antidiurética en el riñón. Los leucotrienos son formados en respuesta a estímulos inmunológicos y no inmunológicos. Variando los ácidos grasos de la dieta es posible influir en el tipo de eicosanoides sintetizados, permitiendo modificar en cierta manera el curso de una enfermedad por medio de la alimentación (Molinas, Torrent y Burgos, 2007).

\subsubsection{Fuente de ácidos grasos n-3}

Los alimentos de origen marino (alga, peces, mariscos) son una buena fuente de EPA y DHA, especialmente los peces grasos (anchoas, sardinas, caballa, arenque). Los aceites vegetales, como los de canola y lino aportan ALA (Valenzuela, Sanhueza y Nieto, 2000). Mientras que el LA, se encuentra principalmente en vegetales y aceites vegetales como los de de girasol, soja, y maíz. El GLA se puede encontrar en aceites de semillas como grosella negra y prímula, y el ARA en productos de origen animal como carne bovina, aves y huevos. Algunas recomendaciones sobre los requerimientos diarios de ácidos grasos poli-insaturados se presentan en la Tabla I-7.

Sin embargo, los niveles de estos ácidos grasos consumidos por la población generalmente son insuficientes debido al bajo consumo de alimentos que los contienen. Dado que los ácidos grasos n-6 y n-3 compiten en el organismo por las mismas enzimas, pero tienen roles biológicos diferentes, se debe tener en cuenta el equilibrio entre ellos en la alimentación. Las recomendaciones de la OMS (2004) es una relación n-6/n-3 de 5/1 a 10/1. En la mayoría de los países de Occidente se consume una dieta muy desequilibrada a favor de los n-6 (relación n-6/n-3 = 20/1), como es el caso de nuestro país, con un elevado consumo de aceite de girasol. Por otro lado, Jiménez-Colmenero (2007) indica que esta relación no debería superar un valor de 4. Como no existe competencia metabólica entre los ácidos grasos n-3 y los insaturados no esenciales representados principalmente por el ácido oleico (18:1, n-9), la sustitución parcial de aceites ricos en ácido linoleico (aceite de girasol) por aceites 
ricos en ácido oleico contribuiría a restablecer el balance $n-6 / n-3$ necesario. A su vez el aumento en la dieta de productos ricos en ácidos grasos de la familia n-3 favorecería el balance de la relación n-6/n-3 que en la actualidad se encuentra en nuestras dietas.

En Argentina las enfermedades del sistema circulatorio son las principales causas de muerte, y son responsables del $30 \%$ del total de las defunciones anuales (INDEC, 2012) Esto ubica al país, en la última década, en cuarto lugar en mortalidad cardiovascular en América (PROPIA, 2005).

\section{I.2.6. Recomendaciones sobre el consumo diario de lípidos}

Como se comentó anteriormente las recomendaciones de la Organización Mundial de la Salud (OMS 2004) indican que la relación ideal n-6/n-3 debe encontrarse entre 5/1 y 10/1. A su vez, la relación recomendada entre PUFAs y SFA se encuentra entre 0.4 y 1.0 (Jiménez-Colmenero, 2007). Por tal motivo, el diseño de alimentos corrientemente ingeridos por la población, con su grasa modificada por disminución de ácidos grasos saturados e incorporación de ácidos grasos n-3 y n-9, serían alternativas más saludables. La fortificación de alimentos con estos ácidos grasos es un área emergente, dentro del campo de desarrollo de nuevos alimentos funcionales, de interés comercial y académico (Lee y col. 2005).

\section{Recomendaciones en el consumo de PUFA}

Con respecto a la cantidad recomendada de PUFA, EPA y DHA, aún no están del todo establecidas, ya que en diferentes países se han estimado cantidades distintas. Valenzuela y Sanhueza (2009) y Maestre del Cura (2012) presentaron tablas con recopilación de estos datos mundiales de consumo de EPA y DHA; en la tabla I-7 se presentan los valores recopilados por dichos autores. Moore y col. (2012) recomiendan un consumo diario de al menos $500 \mathrm{mg} /$ día de EPA + DHA en los adultos saludables. La American Heart Association (AHA, 2010) recomienda 1000 mg/día para las personas con riesgo cardiovascular. En el caso específico de las madres y nodrizas se recomienda un consumo de DHA no menor a $300 \mathrm{mg} /$ día y en el caso de los lactantes y escolares la recomendación está en torno a $150 \mathrm{mg} /$ día de DHA (Valenzuela y Sanhueza, 2009). 
Tabla 1.7: Ingesta recomendada de PUFA EPA y DHA realizadas por distintos organismos internacionales. (Maestre del Cura, 2012 y Valenzuela y Sanhueza, 2009)

\begin{tabular}{|c|c|c|}
\hline Organismo & Población & Recomendación \\
\hline $\begin{array}{l}\text { World Health Organization } \\
\qquad(\mathrm{WHO})\end{array}$ & Adultos en general & 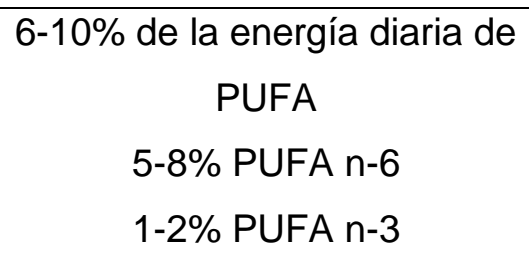 \\
\hline \multirow{3}{*}{$\begin{array}{c}\text { American Heart Association } \\
\text { (AHA) }\end{array}$} & $\begin{array}{l}\text { Adultos Sin } \\
\text { Enfermedad } \\
\text { Cardiovascular }\end{array}$ & $\begin{array}{c}\text { Comer pescado dos a tres } \\
\text { veces a la semana }\end{array}$ \\
\hline & $\begin{array}{l}\text { Adultos Con } \\
\text { Enfermedad } \\
\text { Cardiovascular }\end{array}$ & $\begin{array}{c}\text { 1g/día de EPA+DHA } \\
\text { (Preferiblemente de aceite de } \\
\text { pescado) }\end{array}$ \\
\hline & $\begin{array}{c}\text { Adulto con } \\
\text { Triglicéridos Elevados }\end{array}$ & 2-4 g/día de EPA+DHA \\
\hline $\begin{array}{l}\text { British Nutrition Fundation } \\
\qquad(\mathrm{BNF})\end{array}$ & $\begin{array}{l}\text { Población adulta entre } \\
\qquad 19-50 \text { años }\end{array}$ & EPA + DHA 1.25g/día \\
\hline $\begin{array}{l}\text { Department of Health of } \\
\text { United Kingdom }\end{array}$ & Adultos en general & 200 mg/día \\
\hline $\begin{array}{l}\text { European Academy of } \\
\text { Nutrition Science }\end{array}$ & Adultos en general & 200 mg/día \\
\hline $\begin{array}{l}\text { International Society for the } \\
\text { Study of Fatty acids and } \\
\text { Lipids (ISSFAL) }\end{array}$ & Adultos en general & $\begin{array}{c}650 \text { mg/día de EPA+DHA } \\
220 \text { mg/día al menos de cada } \\
\text { uno }\end{array}$ \\
\hline $\begin{array}{c}\text { National Institute of Health of } \\
\text { U.S. }\end{array}$ & $\begin{array}{c}\text { Mujeres embarazadas } \\
\text { y en lactancia }\end{array}$ & 300 mg/día \\
\hline $\begin{array}{l}\text { National Health and Medical } \\
\text { Research council (Australia) }\end{array}$ & Adultos en general & 190 mg/día \\
\hline
\end{tabular}

Índice de aterogenicidad y trombogenicidad

Los nutricionistas actualmente, están dando énfasis a las dietas equilibradas, a la relación entre los diferentes ácidos grasos que componen un alimento. Varios autores utilizan los índices de aterogenicidad y trombogenicidad a la hora de 
caracterizar y presentar una relación del perfil de ácidos grasos de un alimento y los riesgos para la salud, principalmente de las enfermedades coronarias (López-López y col., 2009; Subhadra y col., 2006; Ulbricht y Southgate, 1991; Kaya y Turan, 2010). Estas patologías representan la principal causa de muerte a nivel mundial (PROPIA, 2004). En otras palabras, estos índices permiten tener una idea entre la relación de ácidos grasos saludables y los perjudiciales presentes en un alimento, asociándolos con el impacto en la salud que puede causar ese alimento al consumidor. Siguiendo los trabajos previos de Andrés y col. (2011), se utilizaron las siguientes índices:

Índice de Aterogenicidad

$\mathrm{IA}=[\mathrm{C} 12: 0+(4 \times \mathrm{C} 14: 0)+(\mathrm{C} 16: 0)] /[(\mathrm{n}-6$ PUFA + n-3 PUFA $)+M U F A] \quad$ Ecuación I-1

Índice de Trombogenicidad

IT $=[C 14: 0+C 16: 0+C 18: 0] /[(0.5 \times M U F A)+(0.5 \times n-6$ PUFA $)+(3 \times n-3$ PUFA $)+(n-3$ PUFA/n-6 PUFA)]

Ecuación I-2

Donde:

PUFA $=18: 2 n-6+18: 3 n-3+20: 4 n-6$

MUFA $=$ incluye los isómeros de 16:1 + 18:1.

La concentración de los ácidos grasos se expresa en g/100.

Estos índices dan una idea de la calidad nutricional de los lípidos (Jankowska y col., 2010). En un alimento saludable, se buscan índices de aterogenicidad y trombogénicos lo más bajos posibles. Esto indica que es más rico en ácidos grasos saludables que perjudiciales.

I.2.7. Deterioro de los ácidos grasos poli-insaturados.

En los lípidos del músculo de pescado, debido a la gran inestabilidad de los ácidos graso poli-insaturados, ocurren dos tipos de reacciones de deterioro a saber:

- Hidrólisis

- Oxidación

La hidrólisis de un lípido consiste en la ruptura de un enlace éster entre un ácido graso y un alcohol mientras que la oxidación lipídica es la incorporación de una molécula de oxígeno molecular a la estructura de un lípido. Ambas reacciones llevan a una reducción en la calidad nutricional de los lípidos presentes en los alimentos. 
La oxidación lipídica, es una reacción química que requiere de tres etapas (Iniciación, Propagación, Terminación). Y como resultado final se producen sustancias, algunas de las cuales, presentan sabores y olores desagradables. Estos olores y sabores son muy característicos e inmediatamente se los asocia con el gusto a "rancio", incluso algunas pueden ser tóxicas. Algunas de estas reacciones también pueden contribuir a cambios de textura mediante uniones covalentes a las proteínas musculares.

La intensidad con la cual los pescados o productos de la pesca son susceptibles al deterioro de los lípidos depende principalmente de la cantidad y calidad de los lípidos que los constituyen. Las especies grasas dada la abundancia de lípidos en el músculo, son particularmente susceptibles a la degradación lipídica, la cual puede ocasionar severos problemas en la calidad, incluso durante el almacenamiento a temperaturas bajo cero. Durante el almacenamiento del pescado, aparece una cantidad considerable de ácidos grasos libres (AGL) y otros productos de hidrólisis como diglicéridos y monoglicéridos. La reacción tiene mayor repercusión en el pescado no eviscerado que en el eviscerado, probablemente por la presencia de enzimas digestivas. Los triglicéridos presentes en los depósitos de grasas son hidrolizados por la trigliceril-lipasa, originada en el tracto digestivo o liberada por ciertos microorganismos (Maestre del Cura, 2012).

El alto contenido de PUFAs presentes en los pescados y productos de la pesca, enriquece notablemente su valor nutricional pero desde el punto de vista tecnológico presentan un serio problema respecto de su estabilidad y conservación. Los ácidos grasos poli-insaturados son compuestos muy susceptibles a reacciones de oxidación en presencia de oxigeno, produciendo sabores, olores y colores desagradables; compuestos que pueden ser incluso tóxicos para la salud por sus efectos citotóxicos y genotóxicos. La oxidación origina radicales libres y peróxidos, los cuales están asociados a algunos tipos de cáncer, arteriosclorosis, artritis, enfermedades neurodegenerativas y con el proceso de envejecimiento (Hoberman y San George, 1988; Alghazeer, Saeed y Howell, 2008; Maestre del Cura, 2012).

El tiempo de almacenamiento y conservación se ve disminuido en este tipo de productos debido a la susceptibilidad de los mismos; por lo cual muchos investigadores estudian la manera de aumentar la vida útil de los productos ricos y/o enriquecidos con ácidos grasos poli-insaturados (Andrés, Zaritzky y Califano, 2009; Balev y col., 2009; Maqsood y Benjakul, 2009; Moore y col., 2012; Sanchez-Alonso, Haji-Maleki y Boderías, 2007). 


\section{I.2.8. Mecanismo de oxidación de los lípidos insaturados}

La oxidación de los lípidos se produce mediante varias reacciones (Figura I-3). En los alimentos, los lípidos, pueden oxidarse por medio de mecanismos enzimáticos y no enzimáticos (también llamados químicos). La oxidación no enzimática es un proceso no espontáneo, primero se deben formar radicales libres de los sustratos lipídicos. Se cree que la auto-oxidación (oxidación en presencia de oxigeno molecular) es la principal reacción implicada en el deterioro de los lípidos. Tienen lugar por mecanismos de radicales libres y según Fennema (1996) se caracterizan por:

- Una marcada inhibición por especies químicas que interfieren con otras reacciones de radicales libres,

- Están catalizadas por la luz y por sustancias capaces de producir radicales libres,

- Alta producción de hidroperóxidos, $\mathrm{ROOH}$,

- Rendimiento cuánticos superiores a la unidad cuando las reacciones de oxidación se inician por la luz,

- El periodo de inducción es mayor cuando se inician con un sustrato puro.

La oxidación, después de su etapa de iniciación, se transforma en una reacción en cadena de difícil control, aumentando su velocidad muy rápidamente en un corto espacio de tiempo. En la Figura I - 3 se presentan las diferentes reacciones químicas que se producen a lo largo la oxidación de los lípidos. Las moléculas ya oxidadas no pueden retornar a su estado original. Por lo tanto, este proceso no se puede revertir, pero se puede retardar con el uso de antioxidantes.

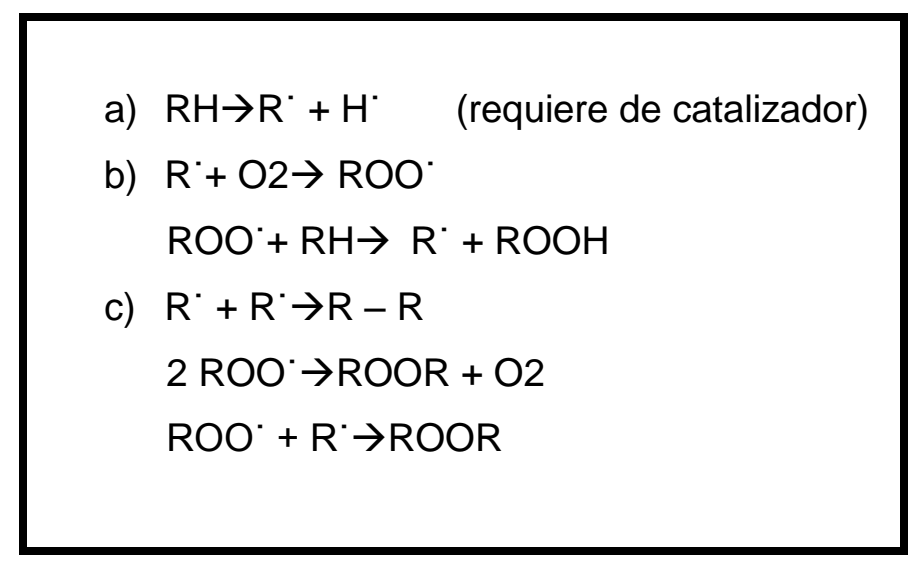

Figura I-3: Mecanismo de la auto-oxidación. a) Iniciación; b) Propagación; c) Terminación. 
Iniciación

En un comienzo, debido a la inestabilidad de algunas moléculas orgánicas y a la presencia de uno o más factores catalizadores, se forma el primer radical libre. A partir que una molécula de ácido graso pierde un protón. Los factores que más influyen en la formación de los radicales libres y que catalizan el proceso de oxidación son, entre otros: la presencia de iones metálicos en el producto (aportados por la sal o por los condimentos), el calor o la luz, la presencia de enzimas, un medio alcalino, la presencia de moléculas con alto nivel de instauraciones en su estructura y la disponibilidad de oxígeno para reaccionar.

\section{Propagación}

Después de la etapa inicial, continua la de Propagación, donde el radical libre es atacado por una molécula de oxígeno y se forma otro radical libre, el radical peróxido (ROO• ). Este radical peróxido ataca a una nueva molécula de ácido graso, que también pierde un átomo de hidrógeno, formando un hidroperóxido y un nuevo radical libre, iniciando un proceso en cadena. Si el oxígeno disponible es suficiente y ningún antioxidante está presente en el producto, esta etapa continuará degradando el producto.

\section{Terminación}

Es la última etapa del proceso, durante la cual, dos radicales libres interaccionan entre sí formando un producto estable. Los peróxidos se combinan, formando moléculas más estables y los hidroperóxidos forman diversas moléculas con funciones ácidas, aldehídicas, alcohólicas, cetónicas, etc. En esta etapa, todo el material es degradado irreversiblemente, llevando a la descomposición total del producto, generando olor rancio y cambio de color, demostrando la oxidación. El desagradable olor rancio es el resultado de la formación de varias moléculas volátiles, algunas de las cuales poseen sabor desagradable y son potencialmente tóxicas. Para que este proceso se paralice, se debe provocar la etapa de Terminación artificialmente, incorporando un antioxidante al sistema. El antioxidante aporta átomos de hidrógeno al sistema, que reacciona con los radicales libres y los peróxidos formados. De esta manera se evita que éstos ataquen a otras moléculas impidiendo la formación de nuevos radicales libres. La molécula del antioxidante al perder el hidrógeno ya no cumple su fin, de tal modo que va perdiendo potencia a medida que las moléculas van cediendo átomos de hidrógeno al sistema.

La susceptibilidad de las sustancias orgánicas a la auto-oxidación depende de la capacidad de donar hidrogeno. Los ácidos grasos más insaturados son más 
susceptibles a iniciar la auto-oxidación que los saturados. Los productos cárnicos cocidos (carnes rojas), durante el almacenamiento, son más susceptibles a la oxidación lipídica que el producto almacenado crudo. Esto se debe a que las operaciones de calentamiento alteran el balance de prooxidante/antioxidante propio del tejido en el alimento porque se mezclan catalizadores de oxidación con lípidos, y esto promueve la oxidación de la mioglobina, liberando el hierro de las proteínas e inactivando enzimas antioxidantes (Lee y col., 2006 a).

Frecuentemente los hidroperóxidos son conocidos como los productos primarios de la oxidación, son compuestos sin sabor y olor. Estos compuestos se caracterizan por su inestabilidad. Su descomposición origina productos secundarios de la oxidación, como aldehídos, cetonas y alcoholes. Estas sustancias son volátiles y están asociadas a olores y sabores desagradables, relacionados con la rancidez en los alimentos. Estas moléculas volátiles son percibidas en muy bajas concentraciones, aún en valores inferiores a 1 ppm (Frankel, 1998). Los aldehídos, generados durante la descomposición de los hidroperóxidos pueden reaccionar con compuestos con grupos amino libres para dar lugar a compuestos de interacción, también denominados compuestos terciarios. Dichos compuestos y sus polímeros son los responsables de la aparición de pigmentos de color pardo.

I.2.9. Control de la velocidad de la oxidación de los lípidos en los alimentos.

Varios factores están relacionados con el proceso de oxidación de los lípidos, sin embargo éstos pueden ser controlados con herramientas que provee la tecnología de alimentos. Estas son las llamadas barreras para reducir la velocidad de reacción de oxidación de los lípidos, como por ejemplo:

- Reducir la temperatura de almacenamiento del producto;

- Reducir el oxigeno circundante;

- Inactivar o eliminar los compuestos pro-oxidantes o la propagación de la reacción de oxidación;

- Utilizar compuestos antioxidantes

\section{I.2.10. Antioxidantes utilizados en alimentos}

Como se describió en la sección anterior, los ácidos grasos insaturados son inestables en presencia de oxigeno, luz y a las elevadas temperaturas. Motivo por el cual es sumamente necesario utilizar antioxidantes para evitar el deterioro. 
Existen distintos tipos de antioxidantes que se utilizan para alimentos, estos puede ser: sintéticos o naturales. El empleo de antioxidantes naturales es una alternativa más saludable respecto a los sintéticos muy eficientes y tradicionalmente usados para controlar el deterioro en alimentos. El empleo de antioxidantes naturales puede, además, reforzar la actividad de los sistemas antioxidantes endógenos aportando una protección extra para el estrés oxidativo. Los alimentos adicionados con antioxidantes naturales pueden ser considerados como alimentos funcionales ya que proveerían de una mejor condición de salud al consumidor (Valenzuela, Sanhueza y Nieto, 2003)

\section{Antioxidantes naturales}

Los antioxidantes naturales son compuestos polifenólicos que se encuentran comúnmente en hierbas, especias, frutas y otros materiales de origen vegetal. Algunos antioxidantes naturales utilizados en alimentos son los tocoferoles y los extractos de romero, té, orégano, salvia, subproductos de la industria del aceite de oliva, entre otros. Los componentes más conocidos de los alimentos con actividades antioxidantes son las vitaminas A, C y E; el $\beta$-caroteno; algunos flavonoides, el selenio mineral y, últimamente, el licopeno compuesto.

En los últimos años se realizaron varias investigaciones para obtener antioxidantes naturales aprovechando los subproductos del procesamiento de frutas y vegetales como de la almendra, uva, tomate, arandano, albahaca y brócoli (Pinelo, 2003; Garrido y col., 2007; Conde, 2009). Estos tipos de antioxidantes son conocidos como extractos, oleoresinas o extractos vegetales y son objeto de numerosos estudios para evaluar sus propiedades y potenciales aplicaciones. Sin embargo el efecto de estos compuestos sobre la estabilidad oxidativa de un sistema alimenticio específico puede ser impredecible, ya que se ve afectada por las condiciones de oxidación y las características de los lípidos del sistema, y otras sustancias activas con propiedades prooxidantes o antioxidantes (Estévez y Cava, 2006). Se obtienen por hidrodestilación y son llamados "aceites esenciales", se caracterizan por ser altamente aromáticos. Para minimizar los aromas propios de los extractos, se les puede realizar una extracción por solvente (etanol, metanol, acetona, hexano, etc.) y así mantener las características beneficiosas del poder antioxidante. De esta manera, los "aceites esenciales" pasan a llamarse "oleoresinas" (Martinello y Pramparo, 2005).

Los extractos de plantas, generalmente son utilizados por sus características aromáticas. Pero estos a su vez presentan una fuerte actividad como donador de átomos de protones $(\mathrm{H} \bullet)$ lo que los vuelve potentes antioxidantes. Los antioxidantes fenólicos se pueden dividir en 4 grupos generales: 
- ácidos fenólicos (gálico, rosmánico y cafeico)

- diterpernos fenólicos (carnosol, carnosico, rosmanol, y rosmadial)

- flavonoides (quercetina, catequina, naringenina y kampemferol)

- aceites volátiles (eugenol, carvacrol, timol y mentol).

Algunos pigmentos de plantas como las antocianinas y la antocianidrina pueden actuar como quelantes de metales y donadores de $\mathrm{H} \bullet$ para el radical oxígeno. El té y los extractos de semillas y piel de uva contiene catequinas, epicatequinas, ácidos fenólicos, proantocianidinas y resveratrol, los cuales contribuyen a la actividad antioxidante (Brewer, 2011). Algunos extractos de plantas son como carnosol, rosmanol, rosmariquinona y rosmaridifenol son mejores antoxidantes que el BHA de origen sintético (Richheimer y col., 1996; Carvalho y col., 2005). Los antioxidantes más efectivos son aquellos que interrumpen la formación de radical libre. Usualmente contienen compuestos con anillos aromáticos o fenólicos. Estos antioxidantes donan $\mathrm{H} \bullet$ a los radicales libres que se forman durante la oxidación y el antioxidante se vuelve un radical. Este radical es estabilizado por resonancia del electrón del anillo aromático y la formación de la estructuras de quinona (Fennema, 1996). La característica común de los flavonoides como flavona, flavonol y flavonona es la estructura básica del flavan de 15 carbonos $\left(\mathrm{C}_{6} \mathrm{C}_{3} \mathrm{C}_{6}\right.$; Figura $\left.\mathrm{I}-4\right)$. La estructura es de 3 anillos ( $\mathrm{A}, \mathrm{B}$ y $\mathrm{C}$ ) y los distintos flavanoides se diferencian por el nivel de saturación del anillo C. La capacidad de los compuestos polifenólicos de actuar sobre los radicales libres producidos durante la oxidación, depende de la estructura, del número y la distribución de los grupos -OH libres del flavanoide (Lupea, Pop y Cacig, 2008). Flavanoides con mayor número de grupos hidroxilo, son más efectivos que los antioxidantes con uno solo. Por lo que los compuestos que presentan estructuras 3,4-orto hidoxilo presentan mayor actividad antioxidante (Geldof y Engeseth, 2002). Algunos flavanoides como naringinina pueden actuar como secuestrantes de metales uniéndolos a su estructura en el grupo 5-hidroxilo y 4 oxo.

Las mezclas de tocoferoles naturales son muy utilizadas por la industria de los alimentos, están compuestas por $d-\alpha, d-\beta, d-\gamma$ y $d-\delta$ tocoferol y pueden ayudar al mantenimiento de la frescura y vida útil de los productos. Estos antioxidantes están siendo cada vez más conocidos y aceptados entre los consumidores, ya que son una forma de la vitamina "E". Sin embargo, se debe tener en cuenta que la declaración del contenido nutricional de vitamina "E" en la etiqueta, debe reflejar la composición de los diferentes tocoferoles de la mezcla utilizada como antioxidante. Existen dos fuentes de mezclas de tocoferol, las cuales están clasificadas de acuerdo al contenido principal de las especies químicas que lo constituyan. Se distinguen " $\alpha$ alta" y " $\alpha$ baja". El 
" $\alpha a$ alta" se utiliza generalmente como un nutriente, porque tiene una alta actividad de vitamina $E$ debido a su concentración mayor de tocoferoles $\alpha$ y $\beta$. Los $\alpha$ tocoferol tienen mayor actividad antioxidante frente a la rancidez oxidativa in-vivo que in-vitro en un alimento.

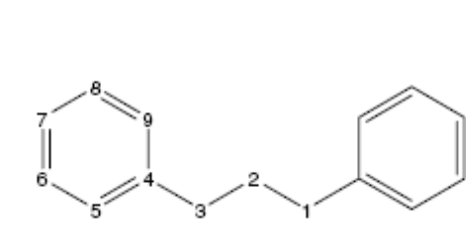

Estructura básica $\mathrm{C}_{6}, \mathrm{C}_{3} ; \mathrm{C}_{6}$

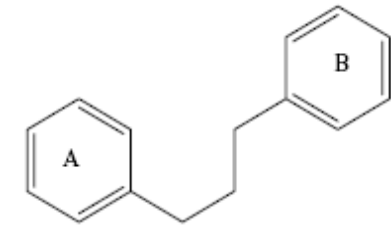

Chalcona

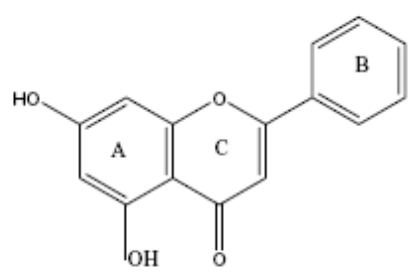

Flavona

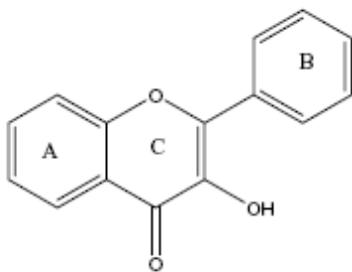

Flavonol

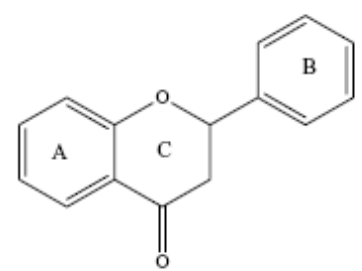

Flavanona

Figura I-4: Estructura general de los flavonoides (Brewer, 2011)

También son muy buenos antioxidantes, pero no tan buenos como los de " $\alpha$ baja", que tienen una concentración mayor de tocoferoles $\gamma$ y y una baja concentración de tocoferoles $\alpha$ y $\beta$. La actividad antioxidante de los tocoferoles $\gamma$ es más potente fuera del organismo, en alimentos, respecto a $\delta, \beta \circ \alpha$. Por lo tanto, las mezclas con alto contenido en "no $\alpha$-tocoferol" son aptas como antioxidantes en alimentos y aplicaciones industriales. Además las mezclas de tocoferoles son resistentes a los pasos de procesamiento de alimentos a altas temperaturas, poseen una baja volatilidad, buena solubilidad en grasas y aceites y han sido probados en numerosos productos (aceites, margarinas, panificados, cárnicos). Los tocoferoles también pueden ser producidos por síntesis química, y poseen la misma estructura química y propiedades que los anteriormente descriptos.

El extracto de uva también presenta actividad antioxidante. Se extrae de las semillas, cavo y ollejo de la uva roja con la que se realizan los vinos. La capacidad antioxidante de los vinos se encuentra asociada al contenido de polifenoles como flavonoides y ácido fenólico (Radovanovic, Radovanovic y Jovancicevic, 2009). La composición de los compuestos fenólicos varia por la variedad de uva, el medio ambiente, las condiciones climáticas, el tipo de suelo, el grado de madurez y el proceso para la obtención del vino (Jayaprakasha, Singh y Sakariah, 2001; Hatzidimitrioua, Nenadisa y Tsimidou, 2007; Xu y col., 2010). Touns y col., (2009) 
reportaron variaciones entre variedades de uvas en el contenido de fenoles totales, flavonoides y taninos. La composición de los fenoles en extracto de semillas y piel de uva contienen: catequinas, epicatequinas, epicatechina-3-O-gallato, ácido fenólico, ácido cafeínico, quercitin, myricetina, proantocianidinas y resveratrol (Figura I - 5 y I 6; Hatzidimitrioua, Nenadisa y Tsimidou, 2007).

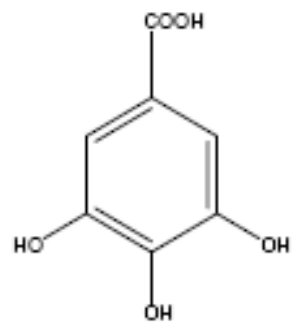

Ácido Gálico

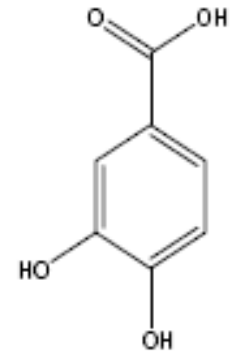

Ácidos Protocateico

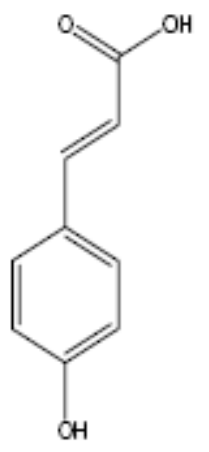

Ácido para-Cumárico

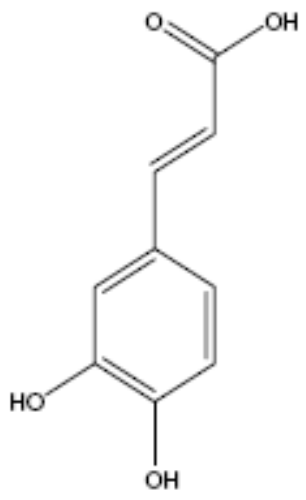

Ácido Caféico

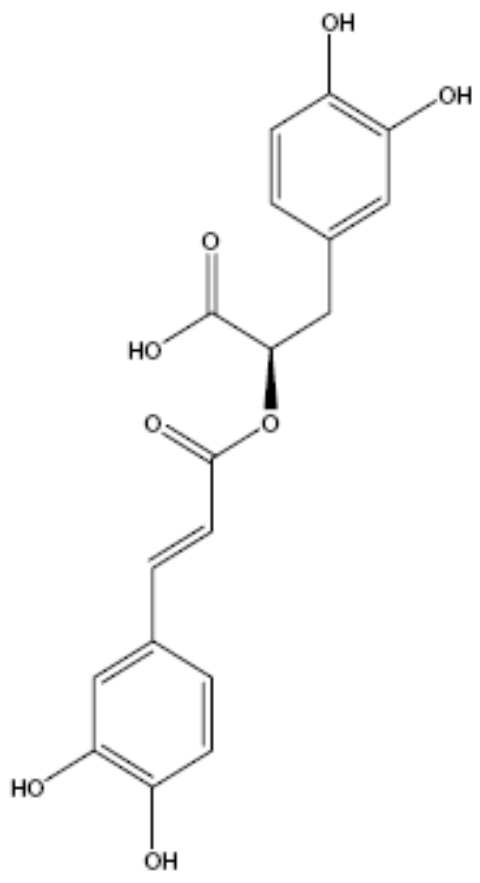

Ácidos Rosmárico

Figura 1-5: Antioxidantes ácidos fenólicos. 


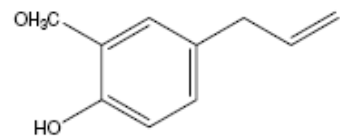

Eugenol

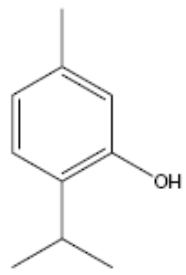

Timol

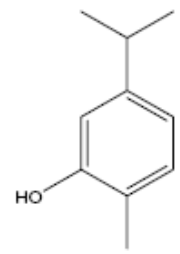

Carvacrol

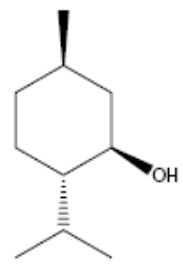

Mentol

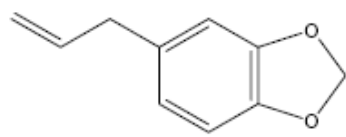

Safrolen

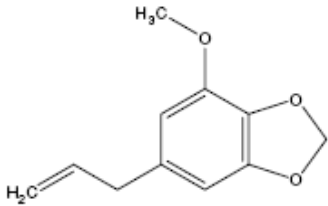

Miricetina<smiles>O=C(/C=C/C=C/c1ccc2c(c1)OCO2)N1CCCCC1</smiles>

Piperina

Figura I - 6: Antioxidantes aceites volátiles.

La mayoría de estos compuestos tienen fuerte actividad antioxidante, y se encuentran en los vinos rojos. Resveratrol, quercitina y rutina se encuentran generalmente en los extractos de piel de uva, mientras que catequina y epicatequina se encuentran en las semillas de uva (Figura I - 7 y I - 8).

Los fenoles de las semillas de uva se desgrasan con solvente, luego se extraen con metanol y se secan bajo vacio. Hu y Skibsted (2002) observaron que el extracto de semillas de uva, inhibe tanto la hidroperoxidación de los lípidos como la formación de propanal en los sistemas de emulsión. El resveratrol, tiene una fuerte actividad antioxidante, mayor que el propil galato, vanillina, fenol, BHT, y a-tocoferol (Murcia y Martinez-Tome, 2001). Esto puede deberse a que presenta 2 anillos fenólicos y mayor cantidad de $-\mathrm{OH}$ que el propil galato, el fenol, el $\mathrm{BHT}$ y el $\alpha$-tocoferol. 
<smiles>Oc1cc(O)c2c(c1)O[C@H](c1ccc(O)c(O)c1)[C@H](O)C2</smiles>

Epicatequina<smiles>O=C(OC1Cc2c(O)cc(O)cc2O[C@H]1c1cc(O)c(O)c(O)c1)c1cc(O)c(O)c(O)c1</smiles>

Galato-Epicatequina<smiles>O=c1c(O)c(-c2ccc(O)c(O)c2)oc2cc(O)cc(O)c12</smiles>

Quercetina<smiles>O=C(O[C@H]1Cc2cc(O)c(O)cc2O[C@H]1c1cc(O)c(O)c(O)c1)c1cc(O)c(O)c(O)c1</smiles>

Galato-Epigalatocatequina

Rutina<smiles></smiles>

Figura I - 7: Antioxidantes flavonoides encontrados en extractos de plantas (Brewer, 2011) 


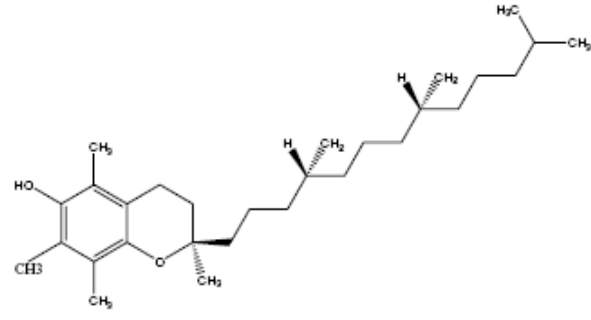

$\alpha$ Tocoferol

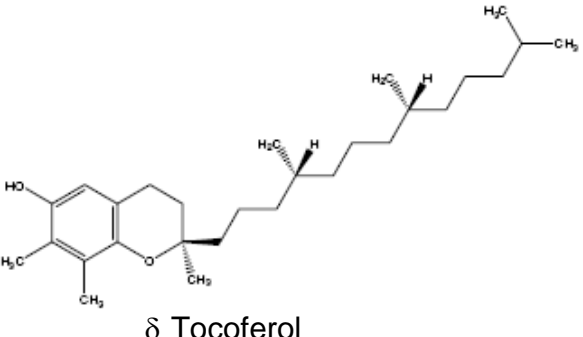

$\delta$ Tocoferol

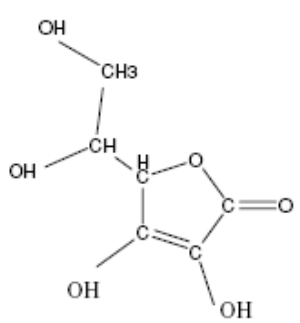

Ácido ascórbico

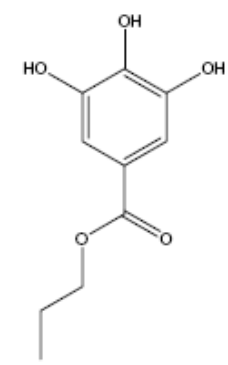

Galato de propilo

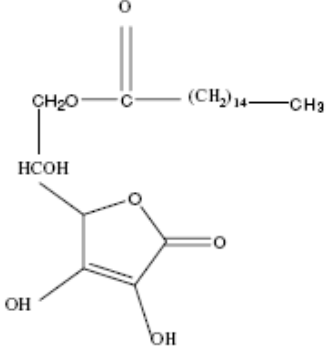

Palmitato de ascórbilo

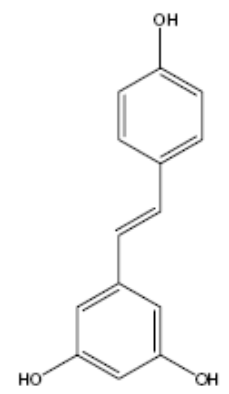

Resverasrol

Figura I - 8: Antioxidantes naturales (Brewer, 2011)

\section{Antioxidantes sintéticos}

Los antioxidantes sintéticos más frecuentemente utilizados en la industria de los alimentos son butil hidroxitolueno (BHT), butil hidroxianisol (BHA), Galato de Propilo y ter-butilhidroquinona (BHTQ). Estos compuestos tienen la desventaja de ser muy volátiles y hay estudios que demuestran que son perjudiciales para la salud, promotores de enfermedades como el cáncer (Hettiarachchy y col., 1996). Debido a esto, en la actualidad existe una importante presión de los consumidores que incentiva la elaboración de productos que provengan de fuentes naturales y que sean producidos por tecnologías no contaminantes (Valenzuela y Nieto 1995; Damechki y col. 2001). 
Muchas veces se utilizan agentes quelantes de metales, también llamados antioxidantes secundarios, en conjunto con los antioxidantes descritos anteriormente. La función de estos agentes es evitar que los iones metálicos que estén presentes en el sistema, puedan catalizar las reacciones de oxidación, evitando también la formación de complejos coloridos. Entre los agentes quelantes más utilizados están el ácido cítrico y el EDTA.

Lee y col. (2006b) controlaron la oxidación en productos cárneos (hamburguesas de pavo y salchichas frescas de cerdo) conteniendo ácidos grasos poli-insaturados n-3 mediante una combinación de extracto de romero $(0.2 \% \mathrm{p} / \mathrm{p})$ como secuestrante de radicales libres, citrato de sodio $(0.5 \% \mathrm{p} / \mathrm{p})$ como quelante de metales y eritorbato de sodio ( $1 \mathrm{~g} / \mathrm{kg}$ producto) como reductor. En estudios previos sobre hamburguesas de carne bovina, con o sin incorporación de $n-3$, evaluaron diferentes combinaciones de quelantes (tripolifosfato de sodio, citrato de sodio), reductores (eritorbato de sodio) y secuestrantes de radicales (BHA, mezcla de tocoferoles y extracto de romero) encontrando los mejores resultados con la combinación citrato, eritorbato y romero (Lee y col. 2005). Meindert Pelser y col. (2007) elaboraron salchichas fermentadas con sustitución parcial de la grasa de cerdo por aceite de lino y canola pre-emulsificada o con aceites de lino y pescado encapsulados, logrando productos aceptables, más saludables, aunque la vida útil de las que contenían aceite de lino o aceite de pescado encapsulado fueron menores debido al aumento de la oxidación lipídica. En trabajos previos del grupo se desarrollaron hamburguesas de carne enriquecidas con n-3 de pescado y aceite alto oleico utilizando antioxidante natural de mezcla de tocoferoles con el agregado de una oleorresina de oregano-romero como antimicrobiano (Pennisi Forell y col., 2010).

Los antioxidantes están reglamentados en el Código Alimentario Argentino (2005) en el capítulo VII “Aceites y Grasas”, artículo 523 bis (resol. 2012 del 19/10/84) y especifica su uso para el agregado en aceites y grasas vegetales comestibles, con la exclusión de su uso en los aceites de oliva de presión no refinados. Fija además, para cada una de estas sustancias o sus mezclas, las dosis máximas permitidas, variables en cada caso, entre 100 y 200 ppm, salvo en tocoferoles naturales o sintéticos los que se pueden agregar en concentración que no exceda la necesaria para lograr el efecto deseado.

\section{I.2.11. Los fitoesteroles}

Desde hace años se conoce que los fitoesteroles (esteroles vegetales con estructura similar al colesterol) producen efecto hipocolesterolémico, por lo cual se les 
considera como importantes aliados en la prevención de las enfermedades cardiovasculares (Valenzuela y Ronco, 2004). De esta manera entran en juego como alimentos funcionales, aquellos desarrollos que incorporen fitoesteroles en su formulación. Son reconocidos como un componente importante de una dieta saludable y de dietas diseñadas para reducir la hipercolesterolemia. El United States National Cholesterol Education Program ha recomendado un suplemento de la dieta con fitoesteroles de $2 \mathrm{~g}$ /día para la reducción del colesterol, lo que disminuiría el colesterol LDL por aproximadamente un $10 \%$ (Ostlund, 2007). Su incorporación en alimentos corrientes sería una alternativa a los suplementos. Se han realizado numerosos esfuerzos para desarrollar métodos de dispersión de los fitoesteroles, dada su naturaleza hidrofóbica y su tendencia a formar cristales estables. A pesar que la "primera generación" de productos apuntaba a incorporarlos en alimentos de alto contenido graso, la "segunda generación" se orienta principalmente a formulaciones de alimentos de bajo contenido graso (Moreau, 2005).

Los fitoesteroles son compuestos de origen vegetal y su estructura es similar al colesterol, del cual se diferencian únicamente en un grupo metilo o etilo en su cadena lateral (Figura I-9). Entre los esteroles más destacados se encuentran el campesterol, el $\beta$-sitosterol y el estigmasterol. Los esteroles son estructuralmente similares a los estanoles, estos últimos se diferencian por estar saturados mediante hidrogenación y están presentes en la naturaleza con menor frecuencia. Todos deben ser incorporados a través de la dieta ya que no son sintetizados por el organismo humano. El consumo de fitoesteroles en la dieta varía entre las distintas poblaciones y culturas. El consumo habitual en una dieta occidental es de aproximadamente 100 - $300 \mathrm{mg}$ de esteroles vegetales y 20 - $50 \mathrm{mg}$ de estanoles por día, mientras que las dietas orientales y de las personas vegetarianas, la ingesta alcanza niveles mayores, de aproximadamente 300$500 \mathrm{mg}$ al día.
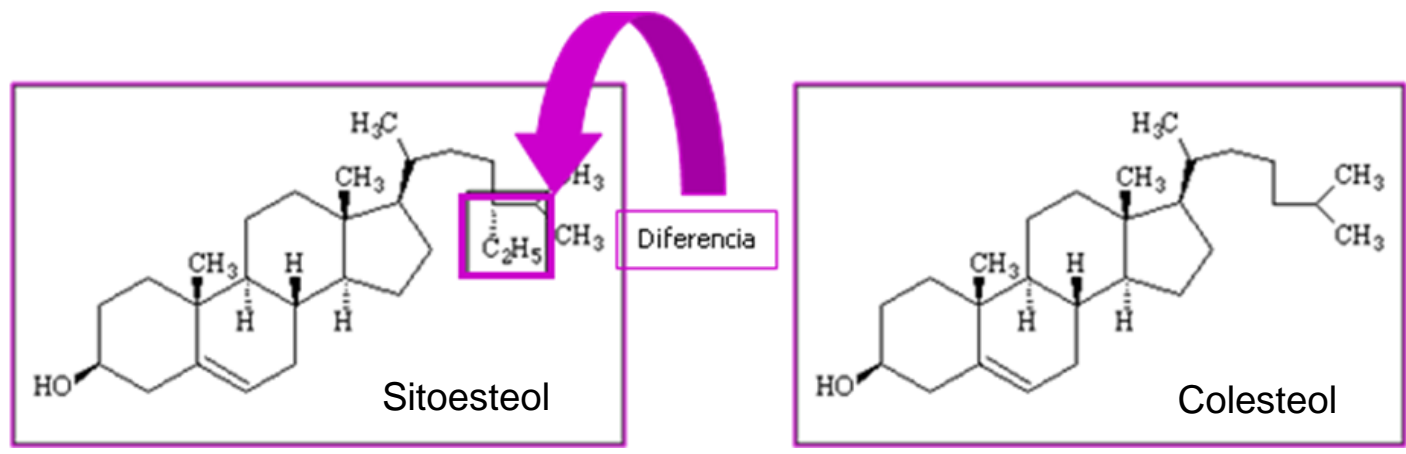

Figura I-9: Diferencia entre Fitoesterol (Izquierda) y Colesterol (Derecha). 
El nivel elevado de colesterol en sangre constituye un importante factor de riesgo para el desarrollo de enfermedades cardiovasculares. Niveles de colesterol en sangre entre 200 y $240 \mathrm{mg} / \mathrm{dl}$ son considerados hipercolesterolemias moderadas y se consideran severas si superan este nivel máximo. El $80 \%$ del colesterol circundante en el plasma está determinado por el genotipo del individuo, donde la edad y estados fisiológicos, como la menopausia en la mujer, incrementan los niveles. El $20 \%$ restante proviene de la dieta (Rossi y col., 2002). La digestión y absorción del colesterol se produce en el intestino. Es transportado hasta la superficie de la microvellosidades de las células epiteliales en la superficie de las micelas mixtas. Se estima que un $50 \%$ del colesterol se reabsorbe, y al ser una molécula que no se metaboliza, la única opción para eliminarlo es a través de las deposiciones (Valenzuela y Ronco 2004).

Hay numerosos estudios que indican que el consumo de fitoesteroles y fitoestanoles reducen los niveles de colesterol total y colesterol LDL tanto estadística como clínicamente, en pacientes hipercolesterolémicos y normocolesterolémicos (Moreau, Whitaker y Hicks, 2002; Jones, Raeini-Sarjaz, y Ntanios, 2000; Plat y Mensick, 2001; Ostlund y col., 2002). Este descenso se observó en dietas normales y en aquellas con bajo contenido lipídico (De Graaf y col., 2002; Jones y col., 2003), por lo cual son considerados como importantes aliados en la prevención de las enfermedades cardiovasculares (Valenzuela y Ronco, 2004). La Food and Drug Administración de los Estados Unidos (FDA, 2000) autorizó la declaración en las etiquetas, referente a la asociación del consumo de fitoesteroles de origen vegetal y la reducción del riesgo de enfermedades coronarias, estableciendo que su consumo diario disminuye tanto el colesterol total en sangre como el LDL en pacientes con hipercolesterolemia leve o moderada.

La absorción intestinal de esteroles y estanoles es menor que la de colesterol (alrededor de un $5 \%$ ) y son eliminados con mayor rapidez por la bilis, por lo que su concentración sanguínea es menor (100 veces menos que el colesterol circulante). Así, del campestanol ingerido se absorbe alrededor de un $13 \%$, del campesterol un 10 $\%$, del estigmasterol un $5 \%$ y del sitosterol un $4 \%$ (Heinemann, Axtmann y von Bergmann, 1993). El sitostanol apenas se absorbería. Sin embargo, los esteroles y estanoles tienen mayor afinidad por las micelas que el colesterol, debido a su gran hidrofobicidad. En consecuencia, pueden desplazar fácilmente al colesterol de las micelas, reduciéndose de esta manera la absorción de colesterol (Melnikov, Seijen ten Hoorn y Eijkelenboom, 2004).

El efecto hipocolesterolémico de los fitoesteroles y fitoestanoles se atribuye a tres acciones metabólicas (Valenzuela y Ronco, 2004) (Figura I-10): 
a) Inhiben la absorción a nivel intestinal del colesterol, tanto de origen dietario como biliar. Al ser más lipofílicos que el colesterol, desplazan competitivamente a las moléculas de colesterol de la micela mixta, reduciendo de esta manera el colesterol disponible para que penetre a las células epiteliales. Los fitoesteroles, fitoestanoles y el colesterol que no son absorbidos, son excretados.

b) Inhiben la reesterificación del colesterol a nivel de la actividad de la enzima específica, acilCoA-colesterol-aciltransferasa (ACAT). De esta manera, el colesterol no se puede incorporar a los quilomicrones y se estimula el eflujo hacia el lumen intestinal del colesterol no esterificado.

c) Aumentan la actividad y la expresión del transportador tipo ABC, acelerando el eflujo de colesterol desde las células intestinales al lumen intestinal y eliminándose durante la excreción.

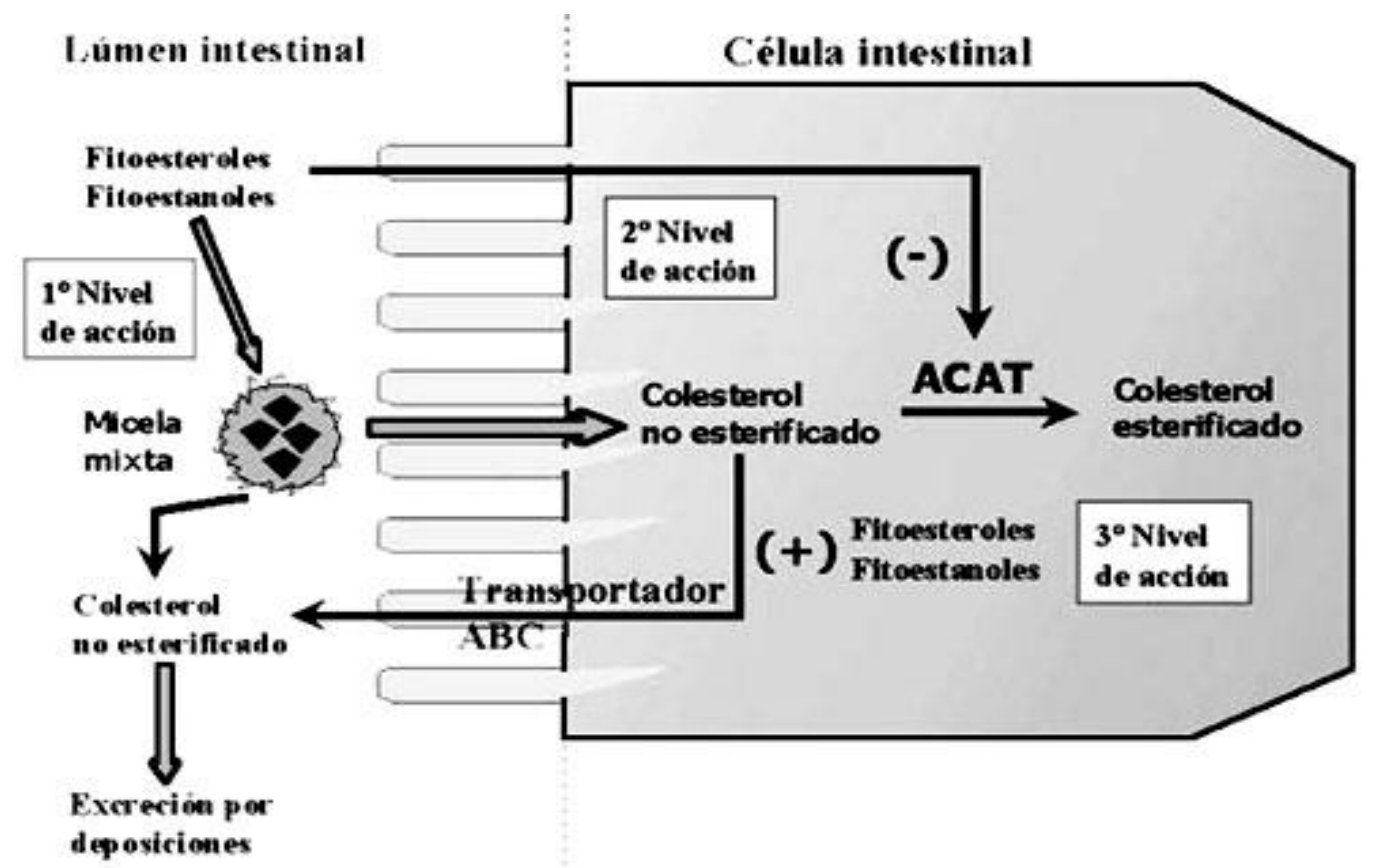

Figura l-10: Mecanismo de acción de fitoesteroles y fitoestanoles

La adición de fitoesteroles y fitoestanoles se ha aplicado en varios productos alimenticios. Trabajos recientes han demostrado que el consumo de margarinas enriquecidas con $\alpha$-sitosterol, campesterol y stigmasterol, 0 con el derivado hidrogenado sitostanol, administradas a individuos moderadamente hipercolesterolémicos, producen reducciones del colesterol circulante de un $10 \%$ en promedio, y de un $8 \%$ en el colesterol LDL, sin afectar el contenido de colesterol de alta densidad (HDL) y el nivel de triglicéridos. El consumo promedio de fitoesteroles para estos estudios fue de 1.5 - $2.2 \mathrm{~g} /$ día y el de sitostanol de $2.0 \mathrm{~g} /$ día (Amundsen y 
col., 2002). Mata (2007) estudió el consumo de margarinas con fitoesteroles, donde su proporción fue de $2.5 \mathrm{~g}$ diarios, con la consiguiente reducción de 20 mg (11\%) en el LDL. La acción conjunta de esteroles y estanoles produjo una disminución del colesterol total plasmático y del colesterol LDL, sin modificar los niveles de colesterol HDL.

Otros estudios indican que el consumo de $2 \mathrm{~g} /$ día de esteroles o estanoles puede reducir el riesgo de enfermedad coronaria en un $25 \%$, efecto que se considera más significativo que la reducción de la ingesta de grasa saturada (Law, 2000; Jones, Raeini-Sarjaz y Ntanios, 2000; Hicks y Moreau, 2001). Mientras que en un trabajo posterior, Katan y col. (2003) concluye que una ingesta media de 2 g/día de esteroles o estanoles reduce los niveles de colesterol LDL en un $10 \%$.

Todos estos componentes, que potencialmente mejorarían la calidad de vida de las personas, podrían incorporarse a diversos alimentos como productos cárnicos, leches, jugos, yogurt y margarinas, entre otros. Las políticas relativas a la alimentación deberían promover el desarrollo, la producción y comercialización de productos alimenticios que contribuyan a una dieta saludable y estén en conformidad con las recomendaciones nacionales e internacionales en materia de alimentación (OMS 2004).

\section{I.3. Desarrollo de productos conformados en la industria pesquera}

\section{I.3.1. Argentina como productor}

Como ya se ha mencionado, Argentina es por excelencia un país exportador de pescado. La situación pesquera del país es similar a lo que sucede en otros países y es consecuencia de diversos factores. En primer lugar, hay una fuerte disminución de las capturas en las últimas décadas, lo que pone de manifiesto en las dificultades que tienen los buques para completar sus bodegas. Esto que lleva a que los productos pesqueros procedentes de las especies tradicionales, suelan presentar un mayor valor en el mercado, ya que son un recurso cada vez más limitado. Simultáneamente, miles de toneladas de pescado sin valor comercial son descartadas: enterradas o enviadas a la elaboración de harina y aceite de pescado. Esto indica que existen especies excedentes que por sus características (sabor, apariencia, forma física, ejemplares juveniles, cantidad de espinas, músculo muy blando, alto contenido en grasa o de pequeño tamaño, de difícil procesamiento, etc.) tienen poca aceptabilidad y no son consideradas comercialmente aptas para el consumo directo. Por otro lado, dada la importancia nutricional del pescado hay un continuo aumento de la demanda de parte de los países importadores, sobre las especies de importancia comercial, para 
abastecer sus crecientes mercados internos. Por ello, la incorporación de nuevas tecnologías con el objetivo de ofrecer al mercado nuevos productos obtenidos a partir de especies de bajo valor comercial, actualmente descartadas o subexplotadas, parece ser una opción no solo interesante desde el punto de vista económico, sino de alto impacto sobre la sustentabilidad.

Realizando una estimación sobre las capturas mundiales de pescado, se calcula que el $72 \%$ de lo desembarcado en puerto es utilizado en el mercado interno como pescado fresco, congelado, o para la producción de enlatado o salado. El 28\% restante es utilizado para el proceso de harina de pescado, alimento para animales o incluso utilizado como fertilizante sin tratamiento previo. A su vez, entre la gran variedad de especies pesqueras, el pescado destinado para consumo humano presenta un rendimiento entre el 25 a $70 \%$ de la materia prima como producto comestible. Considerando como parte útil del pescado, al tronco sin cabeza y sin vísceras, ni aletas, por lo queda incluida la columna vertebral y la piel sin escama. Al referirnos específicamente al rendimiento de filet, este valor depende no sólo de las características previamente mencionadas con respecto a la anatomía de la especie, sino también de la eficiencia manual del operario. Lo que conlleva a estimar que las partes no aprovechables para consumo humano supera el $50 \%$ del volumen total del pescado industrializado para consumo humano. A nivel mundial se estima que 20 millones de toneladas anuales de pescado no aprovechado, son destinadas para la industria harinera (Minozzo, 2010). Esto demuestra que una buena parte del pescado es descartado y no es utilizado para el consumo humano, a pesar de su valor nutritivo. De los restos de procesamiento de fileteado, la carne que queda retenida es de buena calidad alimentaria y se podría extraer para elaborar productos de mayor valor añadido, siguiendo las características sensoriales plateadas por los consumidor a los que se dirigen y de los posibles mercados compradores.

\section{I.3.2. Desmenuzado de pescado}

El desmenuzado de pescado es la carne que se obtiene al separar el músculo de la piel y las espinas en un equipo separador, frecuentemente de banda y tambor perforado. La utilización de desmenuzado de pescado presenta una muy buena ventaja industrial. Permite la posibilidad de modificar o desarrollar formulaciones para productos incorporando fácilmente diversos ingredientes o aditivos (Sánchez-Alonso, Hají-Maleki y Borderías, 2007; Sánchez-Alonso, Solas y Borderías, 2007; SánchezAlonso y Borderías, 2008). En este sentido se podría hablar de la eliminación de unos constituyentes y de la incorporación de otros nuevos. Dentro de estos últimos se 
pueden diferenciar dos funciones importantes de la incorporación: desde un punto de vista tecnológico se pueden modificar las propiedades fisicoquímicas de los productos elaborados y desde un punto de vista funcional, la posibilidad de la incorporación de ingredientes nutracéuticos y permitir que el producto final obtenido pueda enriquecerse en compuestos beneficiosos para la salud, que además puede tener su importancia a nivel de marketing. (Moreno Conde, 2010). Se puede buscar de "imitar un producto" lo que no se refiere únicamente a obtener una réplica exacta del producto original, sino que también se puede obtener un producto similar con imagen de "sano" y "nutritivo" a un precio más económico (Borderías y Pérez Mateos, 1996).

Por otro lado, el desmenuzado de pescado se aprovecha nutricionalmente como alimento de alto valor proteico y alto contenido en ácidos grasos poli-insaturados. Puede ser utilizado como alimento para personas, en especial para niños o ancianos, que temen consumir pescado por causa de las espinas, facilitando y aumentando, de esta manera, el consumo de carne de pescado.

\section{I.3.3. Obtención de desmenuzado mecánicamente}

La obtención de desmenuzado de pescado se logra de diferentes maneras. La tecnología desarrollada para separar la carne de los huesos fue diseñada por los japoneses en los años ' 40 con el objetivo de obtener el tejido muscular del esqueleto de varias especies de pescado luego de ser fileteados de manera convencional (Field, 1988). Incluso se la utiliza para aumentar los rendimientos de carnes rojas, aviares entre otras.

Existen varios equipos para la separación mecánica, la base del funcionamiento de todos es igual, separar la carne de las espinas, huesos y piel. La ventaja de utilizar este tipo de equipamiento, es recuperar el músculo que queda retenido en los "restos", durante el proceso de fileteado (espinazo, recortes como el corte en $\mathrm{V}$ donde se sacan los "pin bons") aumentando el rendimiento de carne. A su vez, se puede utilizar para obtener desmenuzado con especies diferentes a las tradicionales y que por alguna característica particular no son utilizadas como alimento.

La obtención de desmenuzado de pescado se realiza mediante una serie de etapas. Estas dependerán del producto final al que se destine y de la materia prima de la que se parta. Si se utilizan los restos de la industria del filetado (espinazos, recortes), se pasan directamente por el equipo, siempre trabajando con material fresco y controlando las medidas higiénico-sanitarias. Si se utiliza pescado entero, el proceso requiere etapas intermedias. Para ello, se debe recepcionar y acondicionar el pescado, lavar, descabezar, eviscerar y realizar algún tipo de corte o fileteado, como el 
"mariposa", para facilitar la exposición del tejido muscular, para extraer solo el músculo sin el pasaje de piel, espinas y escamas. En esa etapa cuando se utilicen especies grasas; se debe incorporar algún aditivo antioxidante, ya que, el músculo de pescado es muy susceptible a la oxidación. Una vez que se obtiene el desmenuzado, los ácidos grasos poli-insaturados quedan más expuestos al oxigeno y a la acción pro-oxidante del hierro de la mioglobina, provocando un desencadenamiento en el proceso de oxidación lipídica (Chan y col., 1997 y Sohn y col., 2007).

\section{I.3.4. Equipamiento.}

En este trabajo de investigación el equipamiento utilizado fue un separador de piel y espinas BAADER 694. El mecanismo de separación es de banda y tambor cribado, se basa en la extracción del músculo de pescado, utilizando pescado en forma de tronco (sin cabeza y sin vísceras) o en trozos tal como recortes de filetado (cortes $\mathrm{V}$ o J) ingresa al equipo a través de una tolva y es presionado por una banda flexible móvil, contra la parte externa de un cilindro de acero inoxidable perforado. El músculo pasa a través de las perforaciones, mientras que las espinas, los huesos y la piel son retenidos en la parte exterior del tambor y son retirados mediante una rasqueta. De esta manera se logra la separación del músculo de la piel y las espinas, asegurando que el desmenuzado resultante presente una consistencia similar al de la carne picada reteniendo parte de la textura. El tamaño del orificio del tambor perforado que se utilice depende, por lo general, de la especie con la que se trabaje. Cuando se trata de pequeñas especies pelágicas, el tamaño de orificio aconsejado suele ser de 2 ó $3 \mathrm{~mm}$ ya que si fuese más pequeño se originarían alteraciones irreversibles en la capacidad de retención de agua y aumentaría el riesgo de degradación proteica durante su mantenimiento congelado. Cuando se trata de especies de mayor tamaño que poseen espinas mas grandes, el orificio recomendado es de $4 \mathrm{~mm}$.

\section{I.3.5. Almacenamiento}

La carne de pescado es muy susceptible al deterioro si no se acondiciona en frío inmediatamente después de la captura. La mejor manera de evitar el deterioro y mantener sus características como recién capturado es almacenarlo congelado. Durante el proceso de congelación y el posterior almacenamiento congelado, algunas reacciones químicas y enzimáticas se producen en el músculo, causando cambios irreversibles en la funcionalidad de las de proteínas, cambios organolépticos y pérdida de nutrientes. Para evitar el deterioro lipídico se deben incorporar antioxidantes, es 
recomendado congelar inmediatamente luego de su obtención y evitar su mantenimiento refrigerado. Dada las característica estructurales del músculo de pescado, los tecnólogos recomiendan para su conservación en estado congelado temperaturas inferiores a los $-18^{\circ} \mathrm{C}$. Barón y col. (2007), comprobaron en la trucha arcoíris (Oncorhynchus mykiss), que existían mayores alteraciones sobre lípidos y proteínas del pescado congelado durante un periodo de conservación de 13 meses a $20^{\circ} \mathrm{C}$ que a $-80^{\circ} \mathrm{C}$.

Los problemas que pueden suscitarse durante el almacenamiento congelado son la oxidación, desnaturalización y agregación de las proteínas miofibrilares. Se producen compuestos como hidroperóxidos y carbonilos, que influyen en el sabor y el olor. Además se producen entre cruzamientos inter e intramolecular, se forman puentes disulfuro y ditirosina; se fragmentan otras cadenas péptidicas, lo que causan una disminución en la solubilidad proteica. Todos estos procesos, provocan cambios en la textura y la funcionalidad de las proteinas (Lund, Haviid y Skibsted, 2007).

\section{I.3.6. Desarrollo de productos con desmenuzado}

Al desarrollar un producto alimenticio uno de los principales puntos es conocer las características de la materia prima, incluyendo la composición química, las características físicas y la carga microbiológica. En el caso del pescado, en la mayoría de las especies, se observan cambios fisiológicos a lo largo del ciclo biológico. Y estos cambios, influyen directamente en la composición química, las propiedades físicas del músculo y se traducirá en las características del producto que se desarrolle. Por lo tanto, al trabajar con una especie desconocida o con poca información, la primera etapa de trabajo se debe basar en caracterizar la materia prima y sus variaciones a lo largo del ciclo biológico de la especie. Una vez analizadas, es importante evaluar el método de conservación más adecuado para mantener las características iniciales del pescado.

A partir del músculo de pescado desmenuzado se puede elaborar una amplia gama de productos. En particular, la industria pesquera lo utiliza para desarrollar productos como hamburguesas, bastones, salchichas. También es la base para la elaboración del surimi utilizado para desarrollar una infinidad de productos de imitación como es el kani-kama, que simula a la pata de centolla. El desmenuzado de pescado, es una matriz que permite la incorporación de diversos ingredientes, lo que le otorga una gran versatilidad para desarrollar un sinfín de productos, de diferentes sabores, colores, texturas incluso formas. Dentro de esta versatilidad de productos, se puede incorporar no solo ingredientes con finalidad tecnológica, también permiten la el 
agregado de compuestos nutraceúticos, como son las fibras, ácidos grasos, fitoesteroles dando lugar al desarrollo de alimentos funcionales, productos buscados por las nuevas generaciones de consumidores por sus beneficios para la salud (Sánchez-Alonso, Hají-Maleki y Borderías, 2007). El músculo de pescado desmenuzado permite reformular y ampliar la oferta al mercado de un gran abanico de productos pesqueros innovadores, atractivos y más saludables a precios competitivos.

Actualmente existe gran interés por el consumo de productos sanos y de "aspecto fresco", de fácil y rápida preparación o incluso listos para consumir. Uno de los productos por excelencia, considerado como "comida rápida" son las hamburguesas. Las mismas pueden ser de carne, pollo o pescado. A su vez los gobiernos están promoviendo una tendencia mundial para reducir el consumo de sal de sodio agregada a todo tipo de alimentos (AHA, 2006), para reducir las enfermedades relacionadas con la hipertensión.

La formulación de productos conformados, tipo hamburguesas, se realizan principalmente con desmenuzado de merluza, se les adiciona en algunos casos grasa o aceite, pan, pan rallado, agua, condimentos, sal y en algunos casos se agrega texturizado de soja. Se les realiza un rebosado con pan rallado y se someten a un rápida fritura superficial que fija el rebozado y le otorga el color y sabor característicos. Este tipo de producto se comercializa congelado. El pan rallado y el texturizado de soja se agregan con la intención de separa la estructura del pescado y evitar que la textura final sea compacta y elástica. En el caso de las hamburguesas de pescado que tradicionalmente se consumen en Argentina, están diseñadas para consumirlas fritas 0 al horno ya que se las comercializa rebozadas y pre-fritas. Esta característica que las hace muy atractivas limita, en cierta medida, el concepto de saludable. Desde un el punto de vista nutricional este tipo de productos presenta algunas características que pueden considerarse como negativas:

- El pre-fritado que aumenta la incorporación de grasas no saludables en el producto

- La dosis de cloruro de sodio incorporado oscila entre el 1.5 y 2 $\%$, que puede ser perjudicial para las personas propensas a tener enfermedades cardiovasculares.

- El agregado de harina de trigo en forma de pan rallado, limita el consumo de estos productos en las personas que padecen de celiaquía.

Estos ingredientes típicos, presentes en las hamburguesas tradicionales, pueden ser eliminados, sustituidos o remplazados de las formulaciones y desarrollar nuevos productos con similares características a los tradicionales, de buena 
aceptación y con propiedades que los vuelvan benéficos para la salud del consumidor. A su vez volverlo apto para aquellos consumidores con algún tipo de patología que por las características propias de los productos tradicionales no los pueden consumir. 


\section{CAPITULO II}

\section{OBJETIVOS}

El objetivo general de esta Tesis Doctoral es desarrollar productos alimenticios a partir de una especie marina grasa, subutilizada, con alto contenido de ácidos grasos poli-insaturados (saraca, Brevoortia aurea) y enriquecidos con fitoesteroles.

Objetivos específicos:

1. Determinar periódicamente los cambios en la composición química del tejido muscular a lo largo del ciclo biológico de la especie Brevoortia aurea.

2. Caracterizar el desmenuzado de músculo fresco, en diferentes etapas del ciclo biológico de la especie

3. Estudiar la estabilidad del desmenuzado proveniente de músculo fresco pre y post desove, congelado a $-25^{\circ} \mathrm{C}$, y así determinar el período máximo de almacenamiento.

4. Evaluar la efectividad de diversos antioxidantes naturales o sintéticos incorporados en el desmenuzado fresco de saraca en pre y post-desove, y su estabilidad frente a lo oxidación de los lípidos durante su almacenamiento congelado a $-25^{\circ} \mathrm{C}$.

5. Determinar la calidad higiénico-sanitaria del desmenuzado de saraca para su utilización como materia prima segura en alimentos.

6. Desarrollar productos conformados, elaborados a partir de desmenuzado de saraca y enriquecidos con fitoesteroles.

7. Evaluar la efectividad del uso de antioxidantes naturales en el desarrollo de los conformados de saraca.

8. Comparar la efectividad como emulsificante en la formulación de conformados de saraca del concentrado de suero lácteo con $40 \%$ de proteína frente al mismo tipo de producto con un contenido proteico de $80 \%$.

9. Analizar los parámetros de calidad del producto crudo, tales como estabilidad a la oxidación, desarrollo microbiano y calidad higiénico- sanitaria para las distintas formulaciones ensayadas.

10. Evaluar los parámetros de calidad de los conformados cocidos: rendimiento en cocción, capacidad de retención de lípidos y agua, jugosidad, textura, color y evaluación sensorial. 
11. Estudiar, durante 6 meses, los cambios en los parámetros de calidad de medallones cocidos en función de la formulación y el tiempo de almacenamiento a $-25^{\circ} \mathrm{C}$.

12. Evaluar la vida útil de los productos conformados durante el almacenamiento a $-25^{\circ} \mathrm{C}$.

13. Determinar el valor calórico, el contenido de ácidos grasos insaturados de los productos cocidos y su relación con las dosis diarias recomendadas. 


\section{CAPITULO III \\ CARACTERIZACIÓN DEL CICLO BIOLÓGICO}

Brevoortia aurea

El Mar Argentino se carácteriza por su gran diversidad de especies marinas. Un gran número de las mismas se encuentran muy explotadas e incluso en sus límites de explotación, mientras otras especies son consideradas como descarte o sin valor comercial y son desechadas a bordo. Una de las especies sub-explotadas, muy común en la plataforma costera bonaerense, es la lacha o saraca, cuyo nombre científico es Brevoortia aurea.

\section{III.1. Género Brevoortia}

Las especies del género Brevoortia habitan el área costera del Atlántico

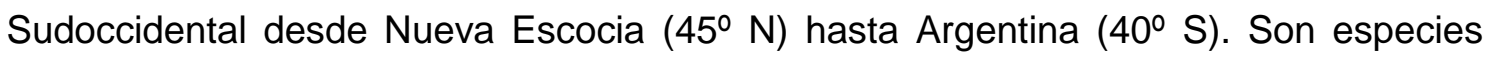
pelágicas, lo que significa que tienen comportamientos de hábitat en toda la columna de agua, principalmente en aguas someras aunque pueden ser halladas a veces a profundidades de $60 \mathrm{~m}$ o más, forman grandes cardúmenes, se alimentan de plancton, son capaces de vivir en un amplio rango de concentración salina sin que se vea afectado su metabolismo, se desplazan en aguas marinas costeras e incursionan en bahías y estuarios. Los géneros de Brevoortia que habitan los mares del norte con frecuencia son capturados en grandes volúmenes mientras que el género que habita el hemisferio sur (Brevoortia aurea) es considerada especie sin valor comercial. Los pequeños volúmenes capturados son utilizados como carnada para otras especies de mayor valor como es el caso del besugo (Pagrus pagrus) (Cousseau y Perrota, 2000).

\section{III.1.1. Especie Brevoortia aurea}

Se conoce bajo el nombre de saraca en Argentina, lacha en Uruguay, savela en Brasil y brazilian menhaden en Estados Unidos. Se distribuye desde Salvador de Bahía (12 $\left.{ }^{\circ} \mathrm{S}\right)$ hasta Bahía Blanca (40S) habitando en zonas estuariales (Figura III-1). Es una especie pelágica de la Familia Clupeidae, (Cousseau y Perrota 2000). En Argentina no tiene valor comercial, por lo cual se descarta en grandes volúmenes entre los meses de julio y octubre durante la pesca de la corvina rubia. Esta pesca se realiza en la bahía de Samborombón, sobre las costas de la provincia de Buenos Aires. Las mayores concentraciones de saraca se encuentran en profundidades menores a $10 \mathrm{~m}$. Los ejemplares adultos efectúan desplazamientos migratorios, Lopez 
Cazorla (1985) encontró una correlación positiva entre el comportamiento migratorio y la temperatura del agua, observó la presencia de peces adultos en las costas de Bahía Blanca en el periodo primavera-verano con temperatura del agua entre $16^{\circ}$ y $23^{\circ} \mathrm{C}$ y ejemplares de escasa talla durante el otoño-invierno, con temperaturas entre $5^{\circ} \mathrm{y}$ $10^{\circ} \mathrm{C}$. En las costas de Mar del Plata la captura se realiza en el periodo octubrefebrero principalmente.

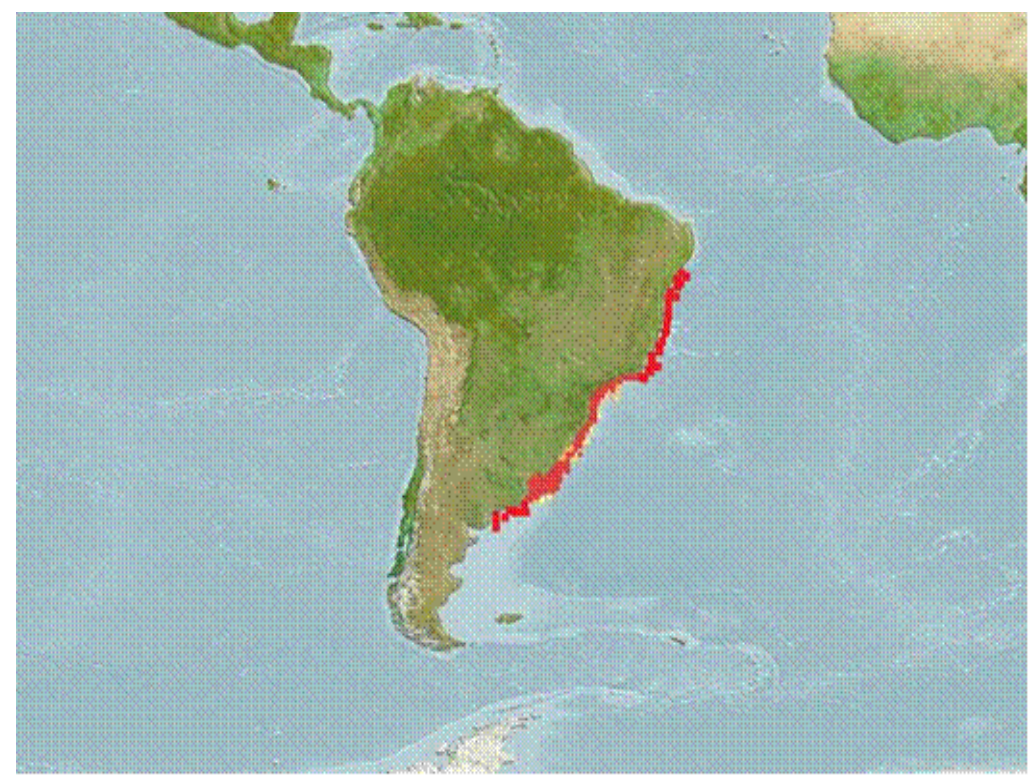

Figura III- 1: Area de captura de saraca.

La edad y el crecimiento fue estudiado por Lopez Cazorla (1985), mediante la lectura de escamas y por la frecuencia de tallas. Este autor observó que el rango de edades entre 0 a 11 años se correlaciona con el intervalo de tallas entre 3 y 40,5 cm. Se consideran juveniles, a los ejemplares con edades entre 0 y 2 años; las hembras entre 3 y 11 años abarcan un intervalo de talla de 22,5 a 40,5 cm. Los machos de 3 a 8 años abarcan el intervalo de 21 a $36 \mathrm{~cm}$. Los ejemplares juveniles de saraca de tallas menores a $29 \mathrm{~mm}$ presentan una alimentación a base de zooplancton, principalmente de copepodos. La anatomía de su aparato digestivo se caracteriza por poseer dentición, escasas branquispinas y un intestino corto. En cambio en los ejemplares adultos existe una transformación del tracto digestivo con el consecuente cambio en la alimentación. A medida que crecen pierden la dentición, aumenta tanto el número de branquispinas como el largo del intestino y en la alimentación comienza el predominio de fitoplancton, preferentemente de diatomeas (Cousseau y Perrota, 2000). Desde el punto de vista ecológico esta especie es de suma importancia en la zona ya que es la única especie costera que constituye el nexo entre la productividad primaria y las tramas tróficas superiores. 
Con respecto al área y época reproductiva Acha (1999) encontró que es un desovante múltiple con fecundidad anual indeterminada. Dicha inferencia se basó en la observación de un proceso continuo de maduración desde la etapa pre-vitelogenica hasta el estadio final de hidratación. A su vez esto se corroboró por la presencia de hembras maduras con folículos post-ovulatorios y oocitos vitelados (estadio de puesta parcial); esto es una indicación que luego de desovar una camada de oocitos, desarrolla una nueva camada que será seguidamente liberada. Es decir, cada hembra desovará en varias oportunidades dentro de una estación reproductiva y con una cierta frecuencia. Se estima que una hembra de $B$. aurea desova cada 8 días como término medio, durante la estación reproductiva. Acha (1999) observó la presencia de huevos de Brevoortia aurea en muestras de plancton durante casi todo el año, principalmente durante la primavera, de septiembre a enero.

\section{III.1.2. Composición química}

La saraca al igual que otras especies marinas pelágicas como: anchoa, arenque, caballa, bonito y atún, se caracterizan por ser pescados grasos, con valores que pueden ser superiores el $20 \%$ de grasa en el músculo. En la composición de los lípidos intervienen fundamentalmente los ácidos grasos poli-insaturados ( $n-3$ y $n-6$ ) que son benéficos para la salud (Adkins y Kelley, 2010; Connor, 2000 y OMS, 2004). Estas especies forman parte de la llamada "dieta mediterránea", reconocida mundialmente como un patrón de alimentación saludable, considerado ideal para la prevención de las enfermedades cardiovasculares y el cáncer (Royo, 2004). A su vez la Asociación Americana del Corazón (AHA) recomienda para una nutrición saludable, en individuos sin riesgo cardiovascular, consumir al menos dos raciones de pescado "azul" a la semana (AHA, 2006).

Existe poca bibliografía sobre la composición química y variaciones estacionales de esta especie como en muchas de las especies del Mar Argentino. En el caso particular de la saraca, fue poco estudiada, en parte por la escasa importancia comercial que presenta en la región. Una de las causas por la cual dicha especie no se consume se debe a la gran cantidad de espinas presentes en toda su estructura muscular. El uso de especies marinas sub-explotadas es una alternativa para desarrollar nuevos productos saludables. Debido al alto contenido de lípidos en músculo de saraca (Pennisi Forell, Califano y Manca, 2009) este puede ser utilizado como alternativa para desarrollar productos saludables, a precios accesibles. En las especies pelágicas, la calidad y la composición de los lípidos así como las proteínas, varían de acuerdo al ciclo biológico. Los cambios en la composición influyen 
directamente en las características tecnológicas que se pueden aplicar a la hora de definir el desarrollo de nuevos productos.

\section{III.1.3. Índices morfométricos}

Se sabe que es muy marcada la relación entre las variaciones del estado fisiológico y la composición muscular (Encina y Granado-Lorencio, 1997). Los biólogos utilizan índices morfológicos para expresar la dinámica en la utilización de la energía endógena de órganos tales como gónadas, hígado y la masa corporal (Collins y Anderson, 1995). Uno de estos índices es el Factor de Condición (FC) que se utiliza para definir el estado físico y fisiológico que expresa, de alguna manera, el estado de bienestar de cada ejemplar. Otro es el Índice o Factor Somático (IS) que indica el estado nutricional, al relacionar la energía almacenada como lípidos corporales y proteínas que pueden ser movilizados para enfrentar los requerimientos en períodos sin alimentación (Jobling, 1995). Otro de suma importancia es el Índice Gonadosomático (IGS) que expresa el estado y grado de desarrollo de las gónadas del animal.

En este Capítulo se estudiarán los cambios en la composición química del tejido muscular de la especie Brevoortia aurea a lo largo de su ciclo biológico y se relacionarán con los parámetros morfométricos.

\section{III.2. MATERIALES Y MÉTODOS}

III.2.1. Material utilizado.

Se estudiaron ejemplares frescos de saraca, Brevoortia aurea, capturados en el litoral bonaerense. Las muestras se recolectaron cada 45 - 60 días, dependiendo principalmente de la capturas de esta especie por la flota costera que desembarcaban en los puertos de Mar del Plata y Lavalle (Figura III-2).

Se analizaron un total de 133 ejemplares adultos, durante los meses de julio de 2008 a mayo de 2009, abarcando un ciclo biológico completo.

\section{III.2.2. Preparación y acondicionamiento de las muestras}

Las muestras capturadas se acondicionaron en cajones con abundante hielo hasta su llegada al laboratorio. Inicialmente se determinaron las medidas morfométricas y peso para todos los ejemplares enteros. 


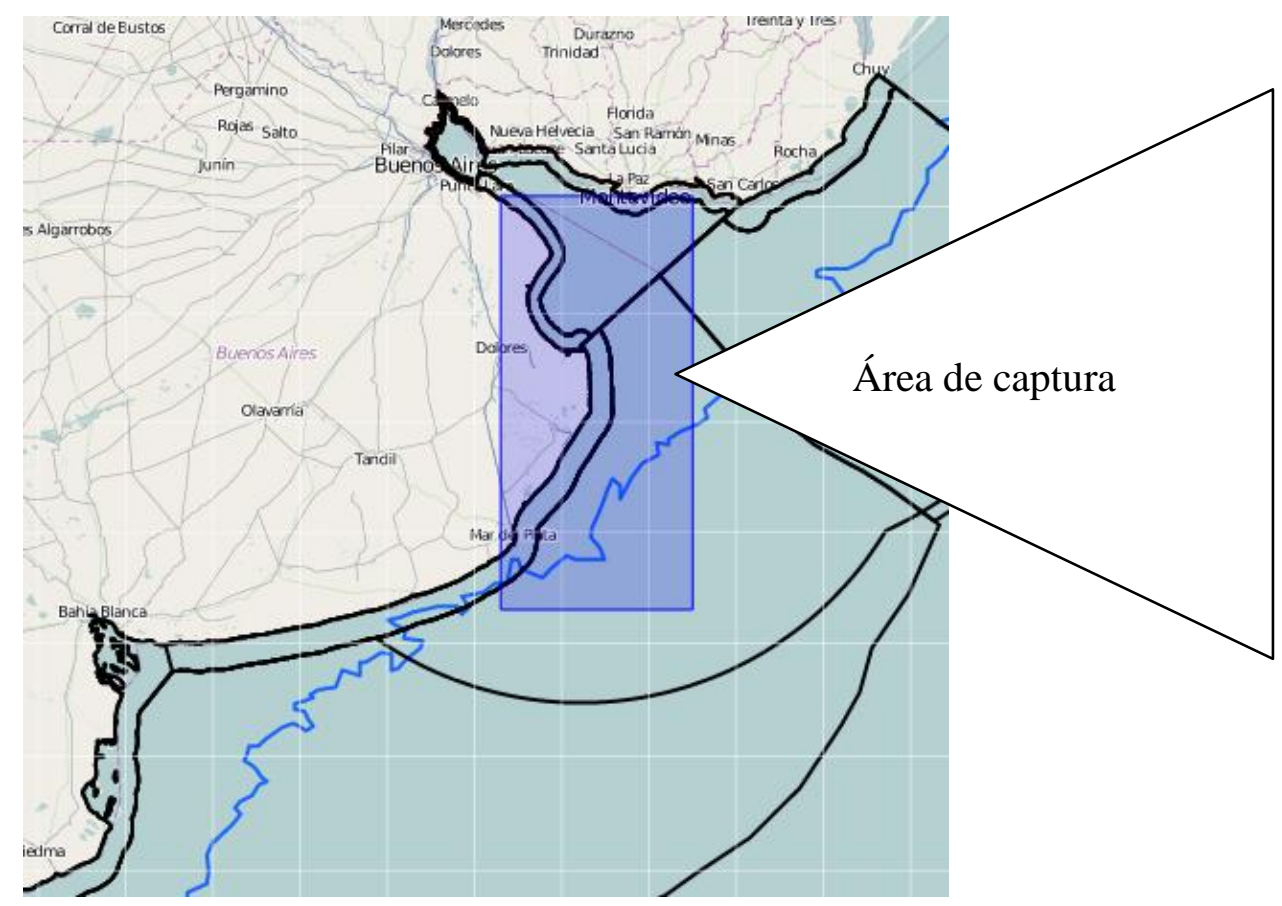

Figura III- 2: Zona de captura de Brevoortia aurea

Las medidas registradas fueron: Longitud Total (LT), Ancho Total (AT), Peso Entero (PE), Peso Eviscerado (PEv) y Peso de las Gónadas (PG). Se utilizó un ictiómetro de $1000 \mathrm{~mm}$ para las medidas de longitud total y una balanza eléctrica Mettler PK 4800 de precisión $0.001 \mathrm{~g}$.

Se determinó el sexo y el estadio de madurez sexual según los parámetros macroscópicos descriptos por Acha (1999) Tabla III-1.

Tabla III- 1: Escala macroscópica de madurez gonadal de Brevoortia aurea (Acha, 1999).

\begin{tabular}{|c|c|c|}
\hline Estadio & Hembra & Machos \\
\hline $\begin{array}{l}\text { Juvenil } \\
\text { Jul }\end{array}$ & $\begin{array}{l}\text { ovarios de reducido } \\
\text { tamaño y translúcidos }\end{array}$ & Testículos filiformes \\
\hline $\begin{array}{l}\text { II } \\
\text { En maduración }\end{array}$ & $\begin{array}{l}\text { Ovarios amarillos claros, } \\
\text { voluminosos, ocupan } \\
\text { hasta parte anterior de la } \\
\text { cavidad. Se observan } \\
\text { ovocitos a simple vista }\end{array}$ & Testículos blanquecinos \\
\hline $\begin{array}{l}\text { III } \\
\text { En desove }\end{array}$ & $\begin{array}{l}\text { Ovarios ocupan la } \\
\text { totalidad de la cavidad. } \\
\text { Los oocitos hidratados se } \\
\text { observan a simple vista }\end{array}$ & $\begin{array}{l}\text { Idem anterior, al presionar } \\
\text { los elimina líquido lechoso }\end{array}$ \\
\hline
\end{tabular}




\begin{tabular}{|l|l|l|}
\hline IV & $\begin{array}{l}\text { Ovarios fláccidos y } \\
\text { congestionados, parecen } \\
\text { sacos vacios, oocitos } \\
\text { vitelados residuales }\end{array}$ & $\begin{array}{l}\text { Testículos amarillentos, } \\
\text { esperma residuales, con } \\
\text { tintes grisáceos o azules }\end{array}$ \\
\hline V & $\begin{array}{l}\text { Ovarios grisáceos con } \\
\text { túnica engrosada }\end{array}$ & $\begin{array}{l}\text { Testículos de escaso } \\
\text { volumen, amarillento y sin } \\
\text { esperma }\end{array}$ \\
\hline
\end{tabular}

III.2.3. Cálculo de parámetros morfométricos

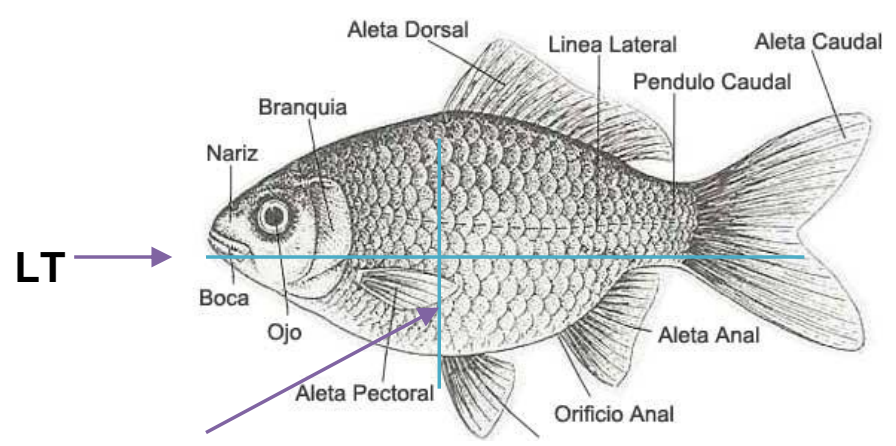

AT Figura III- 3: Anatomía del Pez

$>$ LT: Longitud comprendida entre el extremo frontal y la bifurcación de la aleta caudal, expresada en centímetros (Figura III-3).

> AT: Longitud comprendida entre la aleta dorsal y la aleta ventral, expresada en centímetros (Figura III-3).

$>$ PE: Peso total del ejemplar, expresado en gramos.

$>$ PEv de la canal: Peso tras la disección del paquete abdominal, incluyendo el tracto gastrointestinal, el hígado y las glándulas digestivas, el tejido adiposo periabdominal y las gónadas, expresado en gramos.

$>$ PG: Peso de los órganos sexuales, incluyendo los conductos ováricos o espermáticos, expresado en gramos.

Para cada individuo se calcularon, además, los siguientes índices:

III.2.4. Índices Morfológicos

Factor de condición eviscerado (FCev)

Relaciona el peso de la canal eviscerada y el largo al cubo expresado en porcentaje. Factor de Fulton (Nash, Valencia y Geffen; 2006).

FCev $=100 \times$ PEv/ LT3

Ecuación III-1 
Índice gonadosomático (IGS)

Relaciona el peso total de las gónadas y el peso total del animal sin las gónadas expresada en porcentaje.

IGS $=100 \times P G /(P T-P G)$

Ecuación III-2

Índice somático (IS)

Relaciona el peso de la canal eviscerado y el cuerpo entero expresado en porcentaje:

IS $=100 \times \mathrm{PEv} / \mathrm{PT}$

Ecuación III-3

III.2.5. Determinación del sexo y estadio sexual

Se determinó el sexo y estadio sexual de cada ejemplar por análisis histológico del tejido gonadal. Una sección del mismo se almacenó en formol 10\% para su fijación. La observación del tejido se realizó en el laboratorio de histología del INIDEP. Las muestras fijadas en formol fueron deshidratadas en un equipo Histoquinet y observadas al microscopio. Las gónadas se clasificaron según el grado de madurez e hidratación de los ovocitos en maduración (Estadio II), desoves parciales (Estadio III), posdesove (Estadio IV) y reposo (Estadio V) según lo propuesto por Acha (1999).

III.2.6. Análisis de composición centesimal

Se determinó el contenido inicial de humedad, cenizas, proteínas y lípidos del tejido muscular. Se tomaron 3 hembras y 3 machos de cada muestreo, el tejido muscular de cada ejemplar fue homogenizado por separado y fueron analizados por duplicado.

\section{Humedad}

Se secaron $2 \mathrm{~g}$ de muestra en estufa de vacío a 95 - $100 \stackrel{\circ}{\mathrm{C}}$ hasta llegar a peso constante. Antes de pesar el residuo seco, las muestras se llevaron a temperatura ambiente en desecador. A las muestras se las mezcló con arena, lavada y calcinada previamente, para disgregarla y facilitar el secado. El porcentaje de humedad de las muestras se expresó como g de agua/100 g de producto.

\section{Cenizas}

Se pesaron aproximadamente $0.8-1 \mathrm{~g}$ de muestra en cápsulas de porcelana y se carbonizaron sobre mechero. Esto permite quemar toda la materia orgánica en forma controlada y así evitar la pérdida de muestra por proyecciones, que se fundan o 
formen inclusiones de carbono y que no se incineren adecuadamente en la mufla. Luego se calcinó en mufla a $550{ }^{\circ} \mathrm{C}$ hasta cenizas blanco-grisáceas. Al concluir el programa de calcinación, las muestras se dejaron enfriar en la mufla hasta una temperatura de $40-50 \stackrel{\circ}{\circ}$ y se las colocó en un desecador hasta llegar a temperatura ambiente antes de realizar la pesada. El contenido de cenizas se expresó como g de cenizas/100 g de producto.

\section{Proteína}

Se determinó el contenido proteico mediante el método de Kjeldahl-ArnoldGunning (método 24.027, AOAC 1984). Se mineralizó en un equipo digestor (DK20, Velp, Italia) acoplado a un lavador-neutralizador de gases (SMS Scrubber, Velp, Italia). Se pesaron $0.5 \mathrm{~g}$ de muestra y se colocó en tubo de digestión con $4 \mathrm{~g}$ de mezcla catalizadora (10 g de $\mathrm{K}_{2} \mathrm{SO}_{4} \circ \mathrm{Na}_{2} \mathrm{SO}_{4}, 1 \mathrm{~g}$ de $\mathrm{CuSO}_{4} .5 \mathrm{H}_{2} \mathrm{O}$ ) y $15 \mathrm{ml}$ de $\mathrm{H}_{2} \mathrm{SO}_{4}$ concentrado. La mezcla se calentó según el programa establecido para músculo de pescado, primero suavemente hasta que cesó el desprendimiento de espuma; y luego enérgicamente hasta completar la digestión de la materia orgánica (color azul verdoso translúcido). Se dejó enfriar. El tubo se destiló por arrastre de vapor en un equipo destilador automático (UDK127, Velp, Italia) y se colocó a la salida del refrigerante un erlenmeyer con $40 \mathrm{ml}$ de $\mathrm{H}_{3} \mathrm{BO}_{3}$ al $4 \%$ e indicador Mortimer (rojo de metilo-verde de bromocresol) para recoger el $\mathrm{NH}_{3}$ destilado, cuidando que el extremo del tubo quede sumergido en la solución del erlenmeyer. En forma automática, se dosificó cuidadosamente agua y $\mathrm{NaOH} 32$ \% hasta que la solución tomó color marrón indicando la neutralización del ácido y la alcalinización del medio. Se destiló hasta alcanzar $150 \mathrm{ml}$ en el erlenmeyer colector. El destilado se tituló lentamente con agitación constante con $\mathrm{H}_{2} \mathrm{SO}_{4} 0.065 \mathrm{~N}$ hasta que el indicador viró a su color original (naranja). Se realizó en similares condiciones un blanco de reactivos sin muestra agregada.

Se utilizó el factor de conversión de $6.25 \mathrm{~g}$ proteínas $/ \mathrm{g} \mathrm{N}_{2}$ para calcular el porcentaje de proteínas de la muestra, mediante la siguiente expresión:

$\%$ Proteína $=\frac{(\text { V Muestra }- \text { V Blanco }) \times \text { N Acido } \times 0.014 \times 6.25}{g \text { Muestra }} \times 100$

Ecuación III-4

El contenido se expresó como g de proteína/100 g de producto. 


\section{Lípidos}

Se utilizó el método de Bligh y Dyer modificado por Tanamati y col. (2005). Cada muestra de 10 gramos se homogenizó en un equipo (Virtis, Gardiner, NY) de cuchillas con $25 \mathrm{ml}$ de cloroformo, $50 \mathrm{ml}$ metanol durante 2 minutos. Se agregó $25 \mathrm{ml}$ de cloroformo, se homogenizó 30 segundos, se realizó un tercer homogenizado con $20 \mathrm{ml}$ de agua destilada durante 30 segundos y se centrifugó a 4500 rpm. Se transfirió la fase inferior (clorofórmica) a un balón pesado y se evaporó el solvente en un rotavapor. Se determinó el contenido de lípidos por diferencia de pesada. El contenido se expresó como g de lípidos totales / $100 \mathrm{~g}$ de producto.

\section{Perfil ácidos grasos}

Se realizó sobre fases grasa extraída por el método Bligh y Dyer (III.2.6 Lípidos). Los análisis se realizaron en el Laboratorio de Calidad de la empresa Omega Sur, Parque Industrial Savio, Batán-Mar del Plata. Se utilizó un cromatógrafo de gases marca Shimadzu GC-17A, con inyector Split, y detector de ionización de llama, con columna capilar de sílica fundida Omegawax Supelco 320 (30 m/0,32mm id/0,25 $\mu \mathrm{m})$. Se usó nitrógeno como gas transportador, a un flujo de $25 \mathrm{~cm} / \mathrm{seg}$ y las condiciones cromatográficas fueron: temperatura del detector $250{ }^{\circ} \mathrm{C}$, temperatura del puesto de inyección $260{ }^{\circ} \mathrm{C}$ y temperatura inicial del horno de $190{ }^{\circ} \mathrm{C}$ que se aumentó progresivamente hasta llegar a $225^{\circ} \mathrm{C}$.

La esterificación de los ácidos grasos se realizó según la norma ISO 5509:2000. $0.1 \mathrm{~g}$ de la fase grasa extraída en frío fue disuelta en hexano grado HPLC, se le agregó $0.3 \mathrm{ml}$ de $\mathrm{KOH}$ en metanol y se agitó vigorosamente durante 2 minutos. Se dejó reposar para que precipiten los jabones potásicos. Se agregó $\mathrm{NaCl}$ en solución sobresaturada y se agitó vigorosamente. Este procedimiento transforma los ácidos grasos en sus derivados más volátiles, los ésteres metílicos de ácidos grasos, condición necesaria para su posterior análisis por cromatografía gaseosa.

\section{III.2.7. Análisis estadístico}

Se realizaron análisis de varianza (ANOVA) y el test de Tukey para las comparaciones de pares de medias, considerándose como significativo un nivel de $P<0.05$. Se realizaron regresiones lineales de los parámetros físico-químicos $y$ morfométricos con la talla de los individuos de cada estadio. Las observaciones se informan como el valor medio correspondiente \pm la desviación standard. Se utilizaron los programas SYSTAT (SYSTAT, Inc., Evanston, IL) e InfoStat (grupo InfoStat, Universidad Nacional de Córdoba, Argentina). 


\section{III.3. RESULTADOS Y DISCUSIÓN}

\section{III.3.1. Características del muestreo}

En la Tabla III-2 se presentan las medias y sus correspondientes desvíos estándar de las medidas morfométricas obtenidas en los diferentes muestreos durante el ciclo anual julio 2008 mayo 2009. Se observaron diferencias significativas en las siguientes variables analizadas: Largo Total (LT), el Ancho Total (AT) y el Peso Entero (PE). En el rango de tallas muestreadas, de 28.1 a $41.0 \mathrm{~cm}$ de largo total, no se encontraron diferencias significativas entre hembras y en machos en cada periodo analizado $(P>0.01)$. Si bien la talla de primera madurez es de $32 \mathrm{~cm}$ (Acha, 1999), se encontraron ejemplares adultos de talla menor a dicho valor.

Los ejemplares de mayor tamaño se presentaron en julio con una media de $38.1 \pm 2.22 \mathrm{~cm}$ y los ejemplares de menor tamaño correspondieron a enero con una media $33.2 \pm 2.65 \mathrm{~cm}$. En la Figura III-4, se detalla la distribución de tallas de los ejemplares analizados.

Tabla III- 2: Valores Largo Total, Ancho Total y Peso entero.

\begin{tabular}{|c|c|c|c|c|}
\hline Mes & $\begin{array}{l}\text { No } \\
\text { ejemplares }\end{array}$ & $\begin{array}{l}L T \\
(\mathrm{~cm})\end{array}$ & $\begin{array}{l}\boldsymbol{A T} \\
(\mathrm{cm})\end{array}$ & $\begin{array}{l}P E \\
(g)\end{array}$ \\
\hline Julio & 20 & $38.10 \pm 2.22^{c}$ & $11.46 \pm 0.81^{\mathrm{d}}$ & $686.67 \pm 114.05^{d}$ \\
\hline Septiembre & 20 & $34.03 \pm 2.52^{a b}$ & $10.58 \pm 0.84^{b c}$ & $546.72 \pm 131.89^{b c}$ \\
\hline Octubre & 20 & $34.39 \pm 2.16^{\mathrm{ab}}$ & $11.08 \pm 0.66^{\mathrm{cd}}$ & $576.46 \pm 118.98^{\mathrm{cd}}$ \\
\hline Diciembre & 20 & $35.82 \pm 2.34^{b c}$ & $10.20 \pm 0.83^{\mathrm{ab}}$ & $474.56 \pm 99.13^{\mathrm{abc}}$ \\
\hline Enero & 20 & $33.20 \pm 2.65^{\mathrm{a}}$ & $9.91 \pm 0.81^{\mathrm{ab}}$ & $432.55 \pm 114.24^{a}$ \\
\hline Marzo & 20 & $33.74 \pm 2.73^{a b}$ & $10.09 \pm 0.92^{\mathrm{ad}}$ & $493.22 \pm 132.84^{\mathrm{abc}}$ \\
\hline Mayo & 13 & $33.22 \pm 1.71^{\mathrm{a}}$ & $9.78 \pm 0.64^{a}$ & $435.24 \pm 87.58^{\mathrm{ab}}$ \\
\hline
\end{tabular}

* Los resultados se muestran como medias \pm desviación standard. ${ }^{* \star}$ Medias con una letra común no son significativamente diferentes $(p<=0.05)$

En relación al peso total, los ejemplares de mayor peso correspondieron al mes de julio, $686.67 \mathrm{~g}$. Mientras que los de menor peso total fueron los muestreados durante enero; presentando ejemplares del orden de los $200 \mathrm{~g}$. En la Figura III-4 y la Figura III-5, se presenta la distribución y el recuento de tallas de todos los ejemplares analizados. El ancho total fue entre 8.3 y $13 \mathrm{~cm}$. El ejemplar que presentó el ancho menor, se correspondió con el ejemplar de menor talla y peso, mientras que el de mayor ancho total correspondió a un ejemplar de julio. 
Las tallas más abundantes correspondieron al rango entre 33 y $36 \mathrm{~cm}$, y no se observaron diferencias significativas entre hembras y machos. Esto se correlaciona con los valores encontrados por Lopez-Cazorla (1985) de $36 \mathrm{~cm}$ para hembras y 33 $\mathrm{cm}$ para machos en ejemplares adultos.

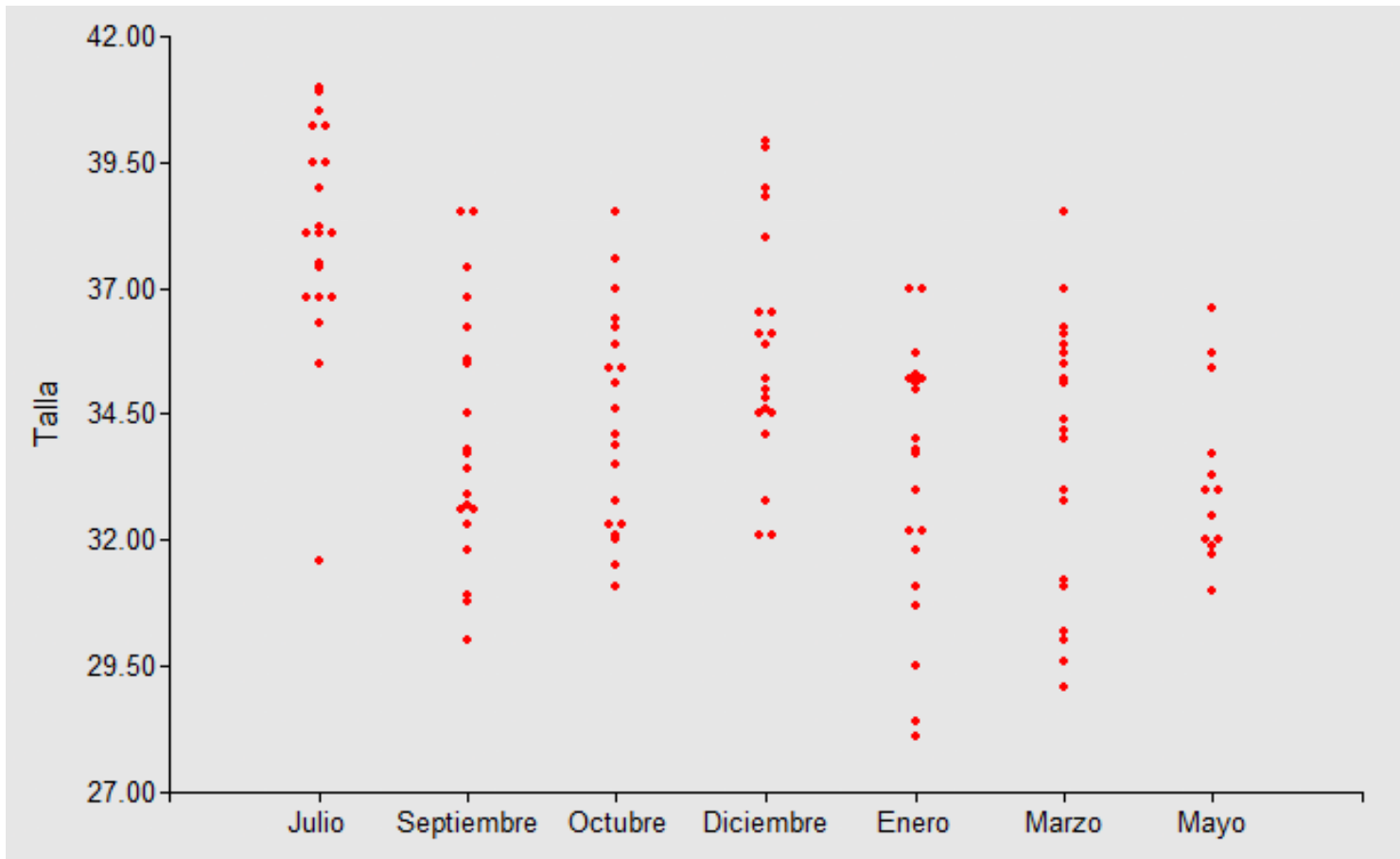

Figura III- 4: Distribucion de tallas muestreadas a lo largo del año.

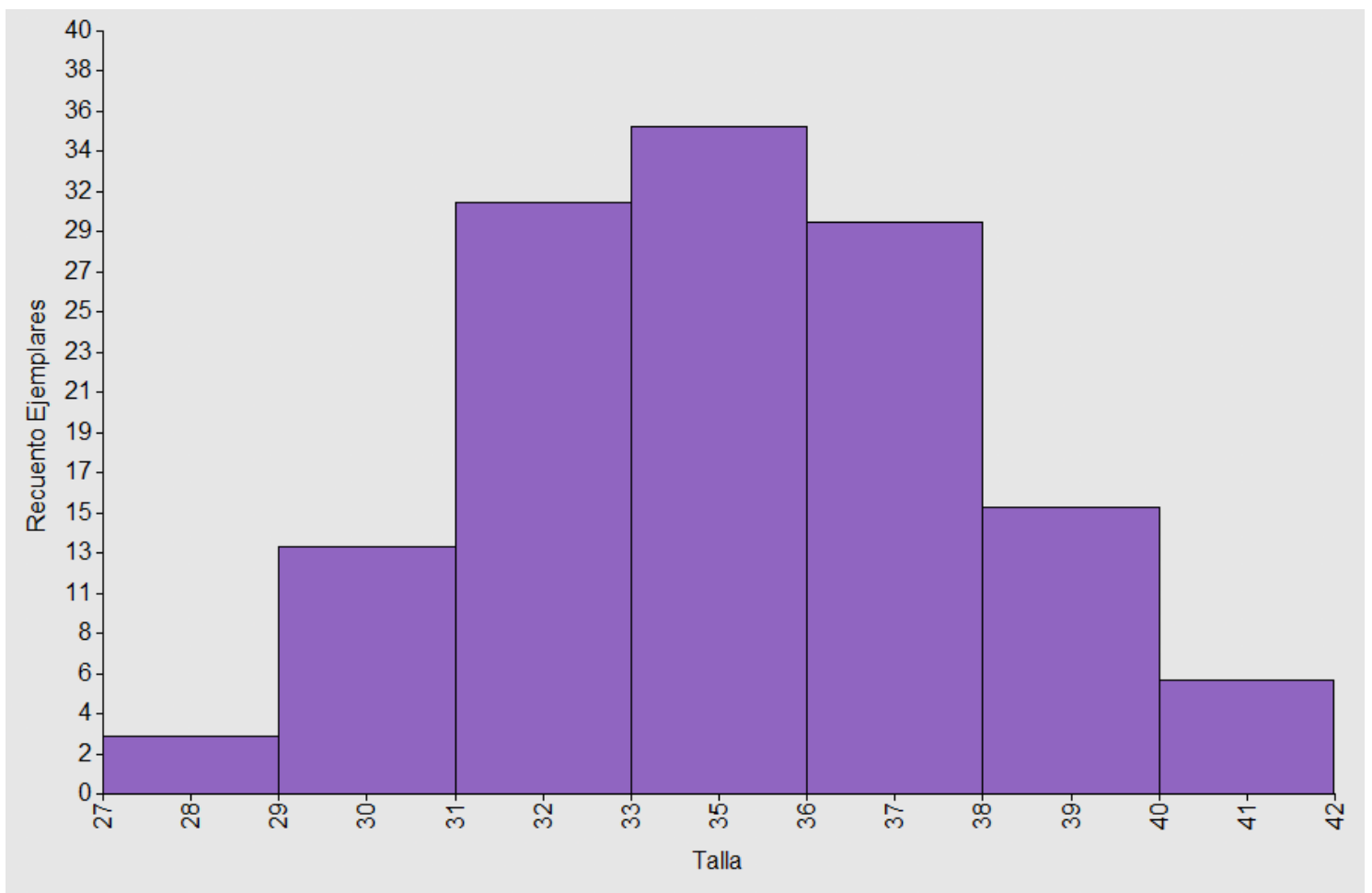

Figura III- 5: Recuento total de tallas de saraca a lo largo del año. 
Se determinó el sexo y el estadio de madurez sexual de manera macroscópica según la Tabla III-1 y se corroboró por análisis histológico de las gónadas. De los 133 ejemplares analizados, se identificaron 96 hembras y 37 machos. Con respecto a los estadios sexuales, se observó que las gónadas de los ejemplares capturados en julio se encontraban en su mayoría en reposo (Estadio $V$ ) y algunos comenzando a madurar sus gónadas (Estadio II). Todos los ejemplares de septiembre presentaron sus gónadas en maduración (Estadio II), mientras que todos los ejemplares de octubre ya se encontraban en desove (Estadio III). En diciembre se encontraron ejemplares en desove (Estadio III) y en pos-desove (Estadio IV). Los ejemplares de enero se encontraron finalizando los desoves (Estadio IV) y algunos ejemplares en reposo (Estadio V), mientras que todos los ejemplares de marzo estaban en reposo (Estadio V). En mayo se encontraron tanto ejemplares en reposo como en comienzo de maduración (Estadio II).

Del análisis histológico de las gónadas durante el ciclo biológico, se pudo determinar la presencia de folículos postovulatorios (indicadores de desove reciente) y ovarios con atresias avanzadas (postdesove y reposo), lo que permitió analizar la distribución anual. Se observó que la especie presenta un ciclo marcado de desove en los meses de primavera-verano (desde octubre hasta enero) que coincide con lo reportado (Macchi y Acha, 2000). Durante este periodo se encontraron gónadas con ovocitos vitelados (Figura III-6), atresias alfa y folículos post-ovulatorios, lo que indica que se encontraban realizando puestas parciales y por otro lado, también en la última etapa de este periodo, se encontraron ejemplares en post-desove. El estadio de reposo se extiende durante los meses de marzo a julio, las gónadas analizadas en este periodo presentaron atresias de tipo alfa, beta y gama, ovocitos previtelogeneticos y la túnica ovárica engrosada (Figura III-7). Los ejemplares analizados entre el mes de julio a septiembre presentaron estructuras en previtelogénesis y ovocitos vitelados lo que indicó el paso de los ejemplares de reposo a maduración. 


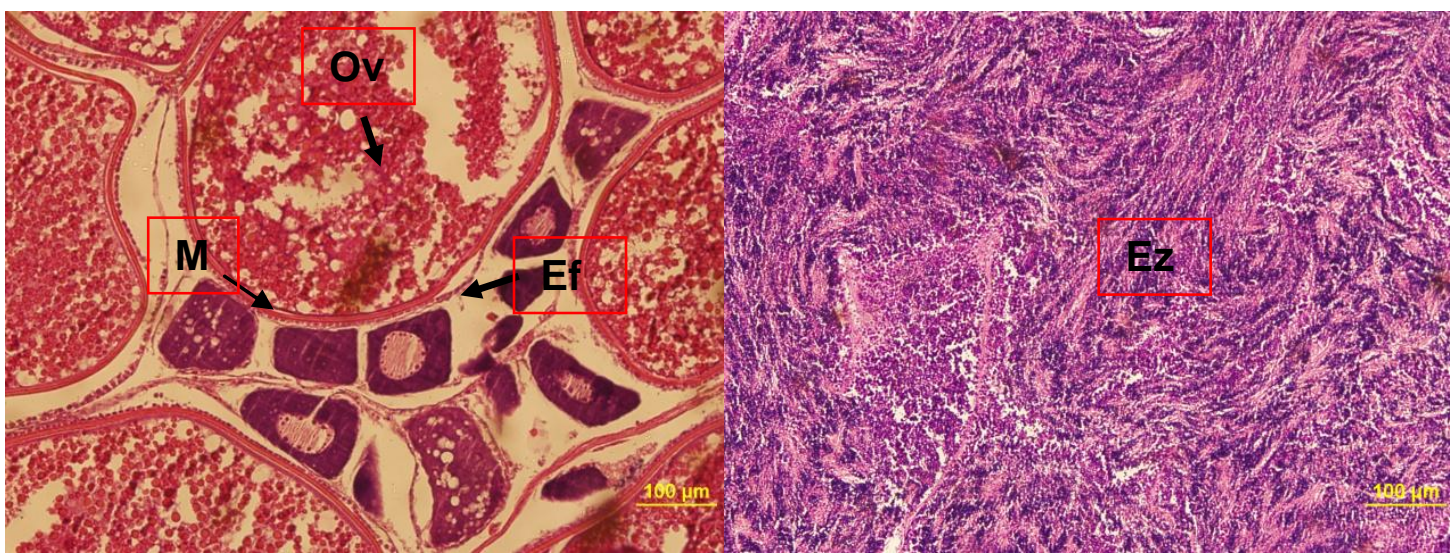

Figura III-6: Corte histológico de gónada maduras Brevoortia aurea (hembra izquierda; macho - derecha; en Estadio II y Estadio III, oocitos vitelados y folículos postovulatorios en hembras). Microscopio invertido (Olympus IX70, con camara digitalizadora Olympus DP71) - 10x.

Hembra: Estadio II ovocitos vitelados de gran tamaño (Ov), membrana pelucida evidente (M) y elementos foliculares (Ef: células de la granulosa y teca) Macho: Estadio III testículo maduro con espermatozoides (Ez) de apariencia desordenada.

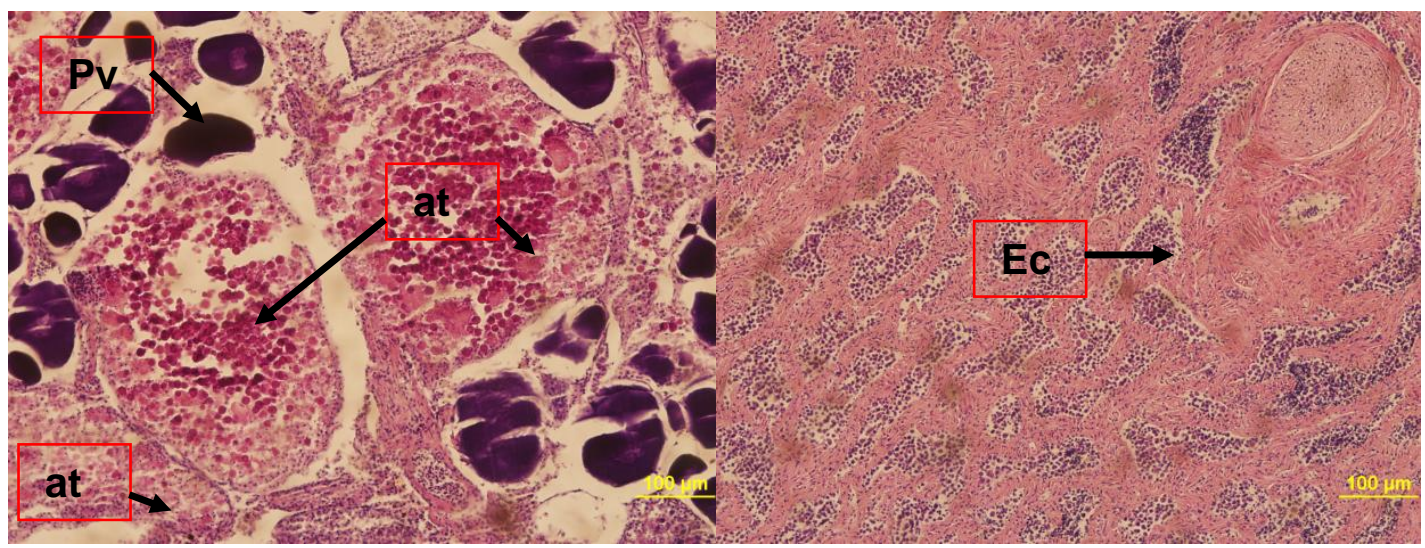

Figura III-7: Corte histológico de gónada en reposo Brevoortia aurea (hembra izquierda; macho - derecha; en Estadio V, tejido con atresia).Microscopio invertido (Olympus IX70, con camara digitalizadora Olympus DP71) - 10x.

Hembra: Estadio V presencia de ovocitos previtelogeneticos (Pv) con gran número de atresias (at) en diferentes fases de reabsorción.

Macho: Estadio V paredes testiculares engrosadas y presencia de células en las primeras fases de la espermatogenesis. (Ec: espermatocitos)

III.3.2. Cálculo de parámetros morfométricos

A partir de los datos morfométricos se obtuvieron los índices morfológicos: el Factor de Condición eviscerado (FCev), el Índice Somático (IS) y el Índice Gonadosomático (IGS). Estos índices permiten evaluar la dinámica de la utilización de energía endógena de órganos tales como gónadas, hígado y la masa corporal (Collins y Anderson, 1995). Es muy marcada la relación entre las variaciones del estado fisiológico y la composición muscular (Encina y Granado-Lorencio, 1997). 
En la Figura III-8 se presentan las variaciones en el IGS e IS, mientras que la Figura III-9 corresponde a los cambios en el FCev. EI IGS presentó diferencias significativas $(\mathrm{P}<0.001)$ entre los distintos periodos, desde julio a octubre las gónadas aumentan significativamente su tamaño, de octubre a diciembre durante el desove el tamaño se reduce significativamente y se mantiene en este tamaño hasta julio donde comienzan a desarrollarse nuevamente. Se encontraron gónadas pequeñas durante el reposo, menores de $15 \mathrm{~g}$, mientras que en el desove se encontraron gónadas de mayor tamaño, hasta de $110 \mathrm{~g}$. El aumento en el peso de las gónadas se debe al desarrollo y crecimiento de las células sexuales (formación de organelas, acumulación de nutrientes durante el desarrollo de gametos femeninos y masculinos, crecimiento del vitelo, formación de vacuolas lipídicas en ovoplasma e hidratación previa al desove). En la Figura III-8 se observa el cambio del peso de las gónadas a medida que avanza el ciclo de desove; presentan un peso máximo al comienzo del periodo de desove (octubre) reflejado en su IGS de 13.9 y un mínimo en el post-desove (marzo), con un IGS de 1.85. El peso de las gónadas de machos en cada periodo fue menor al de las hembras. EI IS presentó un comportamiento inverso al IGS también con diferencias muy significativas $(P<0.001)$. El elevado índice somático durante el reposo, indica la alta cantidad de energía de reserva que almacena en músculo la especie, para destinarlo a las diferentes necesidades durante el periodo de reproducción y llegar con éxito al desove. El IS disminuye a medida que el individuo consume, principalmente, los lípidos durante el ciclo biológico (Tabla III-3). Por otro lado se observa que finalizado el desove en diciembre-enero, presenta rápida recuperación de su condición fisiológica. Estos cambios IS se reflejan directamente en la composición química del músculo.

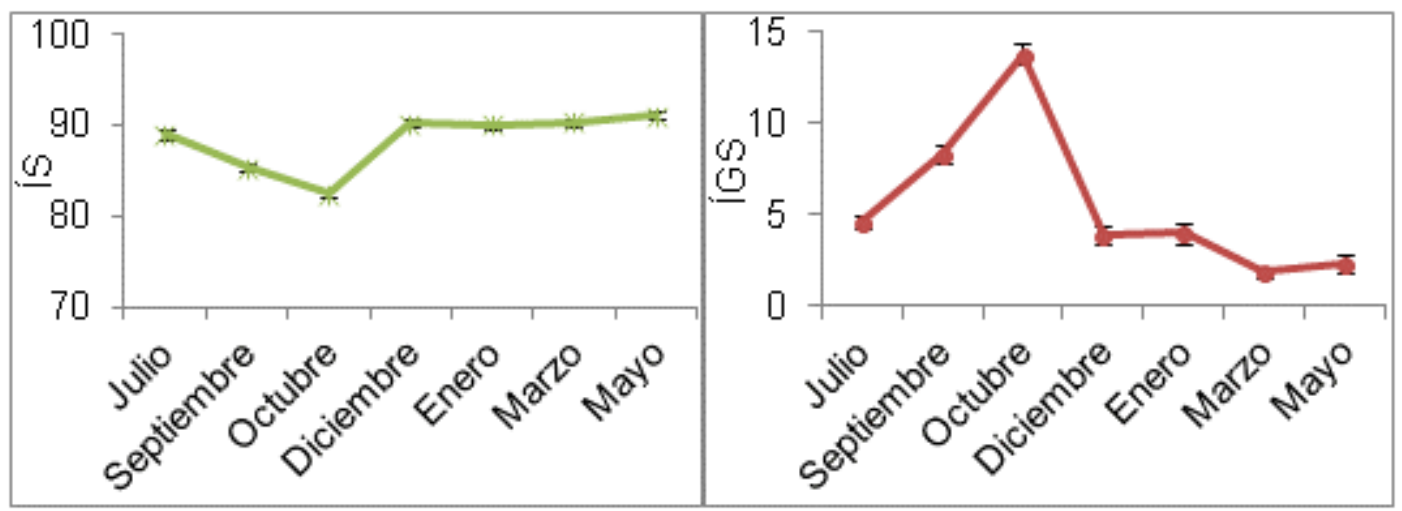

Figura III- 8: Cambio anual a lo largo del ciclo biológico de: Índice somático (izquierda) e Índice gonodosomático (derecha). Las barras expresan el error standard de la media. 
Tabla III- 3:Comparación del Índice somatico de ejemplares de Brevoortia aurea a lo largo del ciclo biológico.

\begin{tabular}{ccc}
\hline Mes & $\mathrm{N}$ & Medias \pm S.D. \\
\hline Julio & 20 & $88.99 \pm 2.81^{\mathrm{c}}$ \\
Septiembre & 20 & $85.30 \pm 1.94^{\mathrm{b}}$ \\
Octubre & 20 & $82.46 \pm 1.95^{\mathrm{a}}$ \\
Diciembre & 20 & $90.18 \pm 1.85^{\mathrm{cd}}$ \\
Enero & 20 & $89.99 \pm 1.95^{\mathrm{cd}}$ \\
Marzo & 20 & $90.33 \pm 1.77^{\mathrm{cd}}$ \\
Mayo & 13 & $90.98 \pm 1.86^{\mathrm{d}}$
\end{tabular}

* Los resultados se muestran como medias \pm desviación stándard. **Letras diferentes dentro de la misma columna indican que los valores medios difieren significativamente.

$$
(P<0.05) \text {. }
$$

EI FCev permite estimar las modificaciones temporales del buen estado de los peces bajo las influencias de factores externos (ambiente) e internos (fisiológicos), independiente de la longitud. Ya que existe un elevado número de factores intervinientes en el "buen estado" del pez (Granados-Lorencio, 2002), el FCev varía según la especie, morfotipo, sexo, edad, estado de madurez, estado reproductivo, época del año y ambiente acuático. Es útil para comparar poblaciones de una misma especie, en distintos ambientes. Para evitar el efecto debido al estado reproductivo de los ejemplares con gónadas hidratadas, se midió el factor de condición de ejemplares eviscerado. Este factor permite observar cambios a lo largo del ciclo anual, se observaron diferencias significativas entre los muestreos realizados. El "peor estado de condición", se encontró en ejemplares de diciembre, valores que se correlacionan con el final de la época de desove. En enero si bien se encuentran algunos ejemplares en desove su factor de condición es mejor que en diciembre (Figura III-9), periodo en el cual comienzan a recuperarse del estadio de desove y además coincide con una mayor disponibilidad de alimento en el hábitat. El FCev aumenta en marzo coincidiendo con el florecimiento de plancton de otoño. En septiembre se observa otro aumento en el FCev y coincide con el florecimiento de plancton a comienzos de la primavera, etapa del año donde la saraca encuentra alimento en abundancia. 


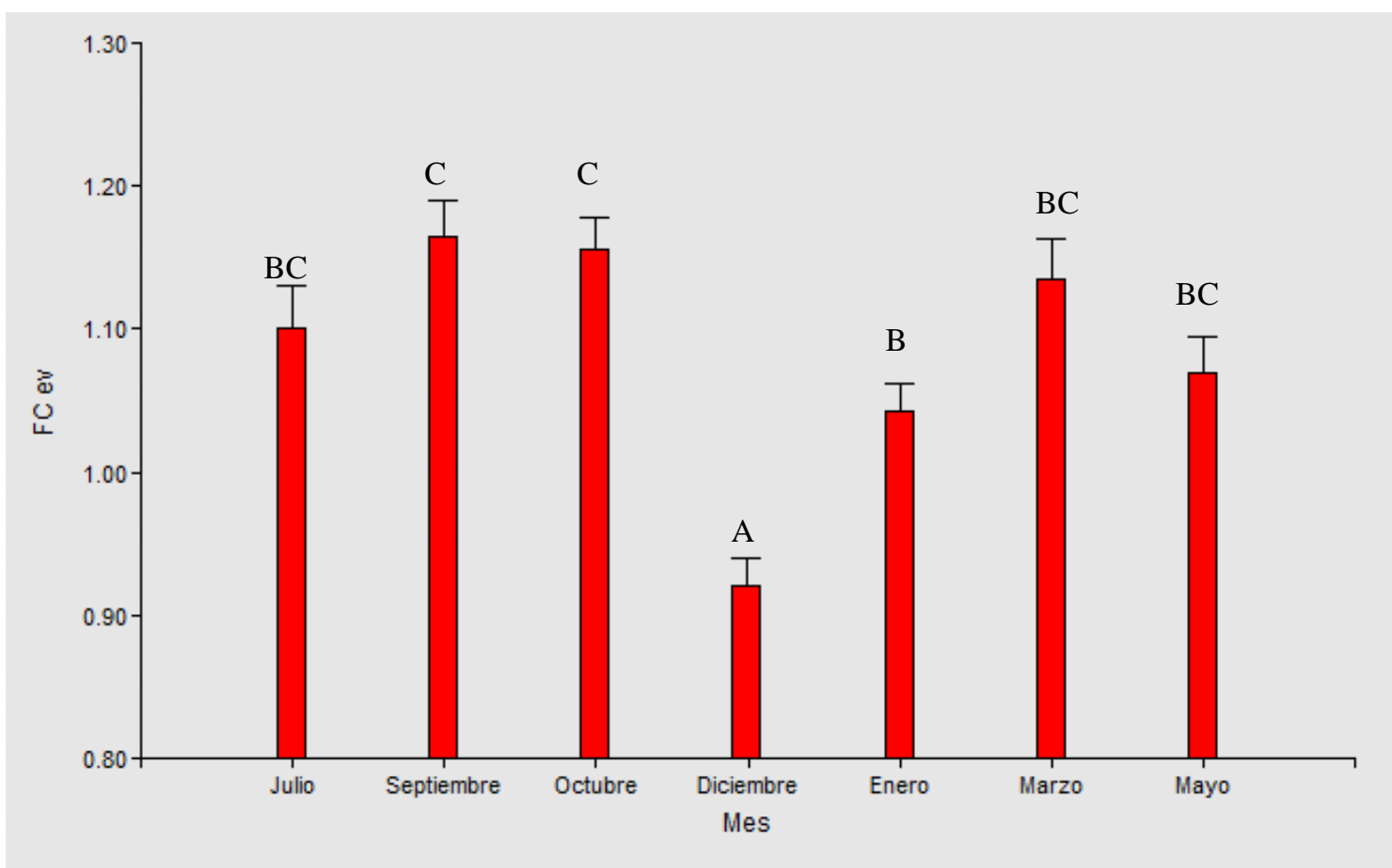

Figura III- 9 Variación del Factor de Condición eviscerado de los ejemplares de saraca a lo largo del ciclo biológico. Las barras expresan el error standard de la media.

*Medias con una letra común no son significativamente diferentes $(P>0.05)$

\section{III.3.3. Análisis de la composición centesimal}

Se observó que en esta especie el contenido de lípidos en el músculo varió significativamente a lo largo del ciclo, siendo una especie semi-magra entre octubre y enero. En diciembre alcanzó valores de $3 \%$ de lípidos en músculo, mientras que en julio alcanzó valores de más de $20 \%$ presentando ejemplares con $28 \%$ de lípido en músculo. La reducción del contenido lipídico entre julio y diciembre (Figura III-10), se debe al esfuerzo energético que requiere para desarrollar gónadas y la movilización de los lípidos que invierte el pez para el desarrollo de los huevos o el esperma (Tocher, 2003), con el fin de asegurar la descendencia.

El gasto energético está dado por la migración hasta las áreas de puesta y por la inadecuada alimentación durante el desplazamiento, debido a escasez de alimento en el trayecto. Otra causa de la reducción de lípidos, está dada por el aumento en el tamaño de los órganos reproductivos, que disminuyen el espacio de la cavidad abdominal y el individuo no puede alimentarse correctamente, por lo que la energía que requiere para todo el proceso proviene principalmente de los lípidos de reserva (Huss, 1988). Por otro lado entre enero y septiembre la especie atraviesa los periodos de post-desove, reposo y comienzo de la maduración donde acumula gran cantidad de lípidos (23\%). Este marcado aumento, se debe principalmente a la buena alimentación 


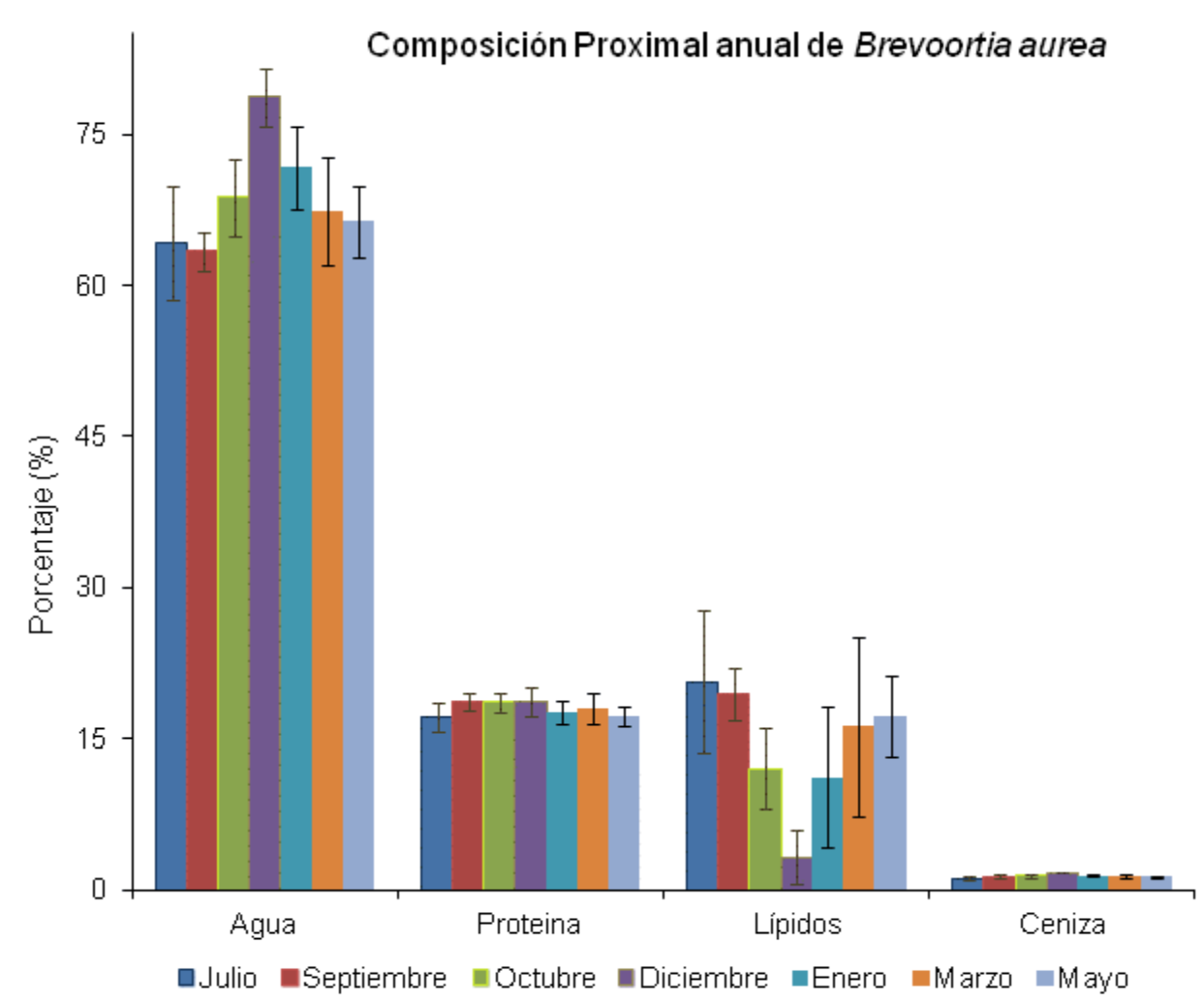

Figura III- 10: Composición química de músculo de saraca en un ciclo biológico. Las barras expresan el error standard de la media.

que logran en dicha etapa. La cantidad y calidad del alimento disponible les permite recuperarse y acumular energía para el siguiente ciclo reproductivo. Durante el final de la primavera y en el otoño disponen de abúndate alimento ya que son periodos de florecimiento de las microalgas, lo que permite la rápida recuperación. Otros autores encontraron variaciones similares en la composición en otras especies pelágicas. Nielsen y col. (2005) encontraron este comportamiento en arenque (Clupea haerngus), Zaboukas y col. (2006) observó una reducción similar del 59.2 \% de los lípidos en bonito (Sarda sarda) y Huss (1988) en el arenque del Mar del Norte.

El contenido de agua, por el contrario, se comportó inversamente, presentó cambios significativos entre los periodos, aumentó significativamente desde la maduración hasta alcanzar en promedio el $78 \%$ al término del desove. Durante el periodo de post-desove pierde agua llegando a $67 \%$ y se mantiene estable hasta octubre. Como han citado otros trabajos, se observó una fuerte correlación entre el contenido de lípidos y el de agua en el tejido muscular de B. aurea (Figure III-11), siendo: 


$$
\begin{array}{ccc}
\% \text { humedad } & =79.961-0.7928 \times \text { \% lípidos } \quad \text { Ecuación III-5 } \\
R^{2} & =0.9425(P<0.001) .
\end{array}
$$

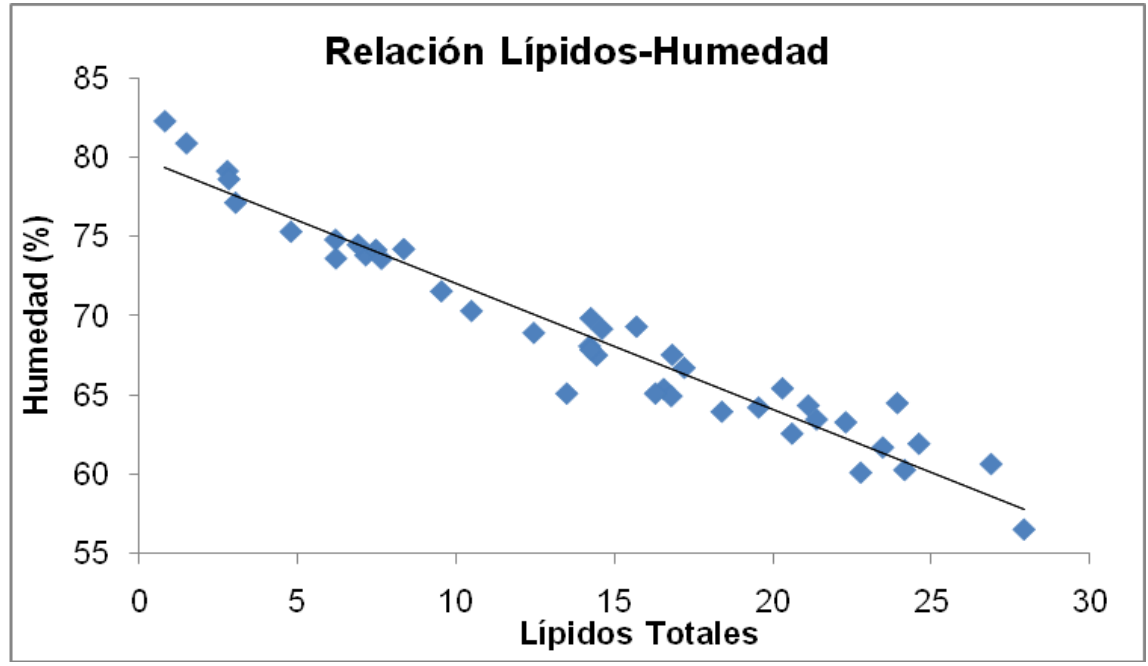

Figura III- 11: Relación lípidos vs. contenido acuoso en músculo $B$. aurea

El contenido agua+grasa constituye cerca del $80 \%$ de la composición del músculo de algunas especies (Huss, 1988). Mientras que las proteínas los minerales y las fibras se mantienen constantes (Nielsen y col., 2005).

Usydus y col. (2011) no observaron diferencias significativas en el contenido de proteínas de ejemplares de bacalao (Gadus morhua); arenque (Clupea harengus) y salmón (Salmo salar), presentando valores de $17.4 \pm 0.9 \%, 18.1 \pm 0.5 \%$ y $18.4 \pm 0.7 \%$ respectivamente. Estos valores se correlacionaron con los resultados obtenidos en saraca, presentando un promedio de $17,99 \pm 1,18 \%$ a lo largo del año. Por otro lado, las cenizas presentaron diferencias significativas $(P<0.001)$, la diferencia se observa en julio con contenido mínimo de $1.09 \pm 0.17 \%$ y máximo de $1.7 \pm 0.05 \%$ en diciembre. El resto del año los valores no presentaron diferencias significativas presentando un contenido medio de $1.36 \pm 0.16 \%$.

\section{III.3.4. Perfil de ácidos grasos}

Como se observó, el contenido de lípidos en músculo es dependiente de la época del año y del estadio sexual en el que se encuentre. Siendo mínimo en diciembre y máximo en julio, este mismo comportamiento fue observado por Zlatanos y Laskaridis (2007) en especies como anchoa (Engraulis encrasicholus) y caramel (Spicara smaris). La composición del perfil de los ácidos grasos (Tabla III-4) muestra marcadas diferencias a lo largo del año. Se observa que para todos los periodos los 
ácidos grasos más abundantes son el palmítico (16:0), palmitoléico (16:1), oleico (18:1), EPA (20:5) y DHA (22:6). Esta observación se correlaciona con los datos reportados por Guner y col. (1998); Karakoltsidis, Zotos y Constantinides (1995); Zlatanos y Laskaridis (2007) y Huynh y Kitts (2009). En el periodo de desove, de julio a diciembre se observó un menor contenido de palmítico presentando su menor contenido en octubre ( $23.98 \pm 1.43 \%)$, aumentando significativamente durante el resto del año alcanzando un máximo en marzo (32.36 $\pm 1.26 \%$ ). En el caso del palmitoléico el valor máximo se observó en julio (13.54 $\pm 1.72 \%)$ disminuyendo significativamente en diciembre $(6.25 \pm 1.78 \%)$ reduciendo a la mitad su contenido. En relación al oleico, su menor contenido se observó al finalizar el desove entre diciembre y enero (15\%), aumentando significativamente en marzo cuando alcanzó la época de reposo. Con respecto al contenido de EPA varía entre $4.09 \pm 0.94 \%$ en marzo y $8.09 \pm 1.27 \%$ en septiembre y el DHA presenta un máximo en diciembre de $18.68 \pm 7.77 \%$ y un mínimo en marzo $4.09 \pm 0.94 \%$.

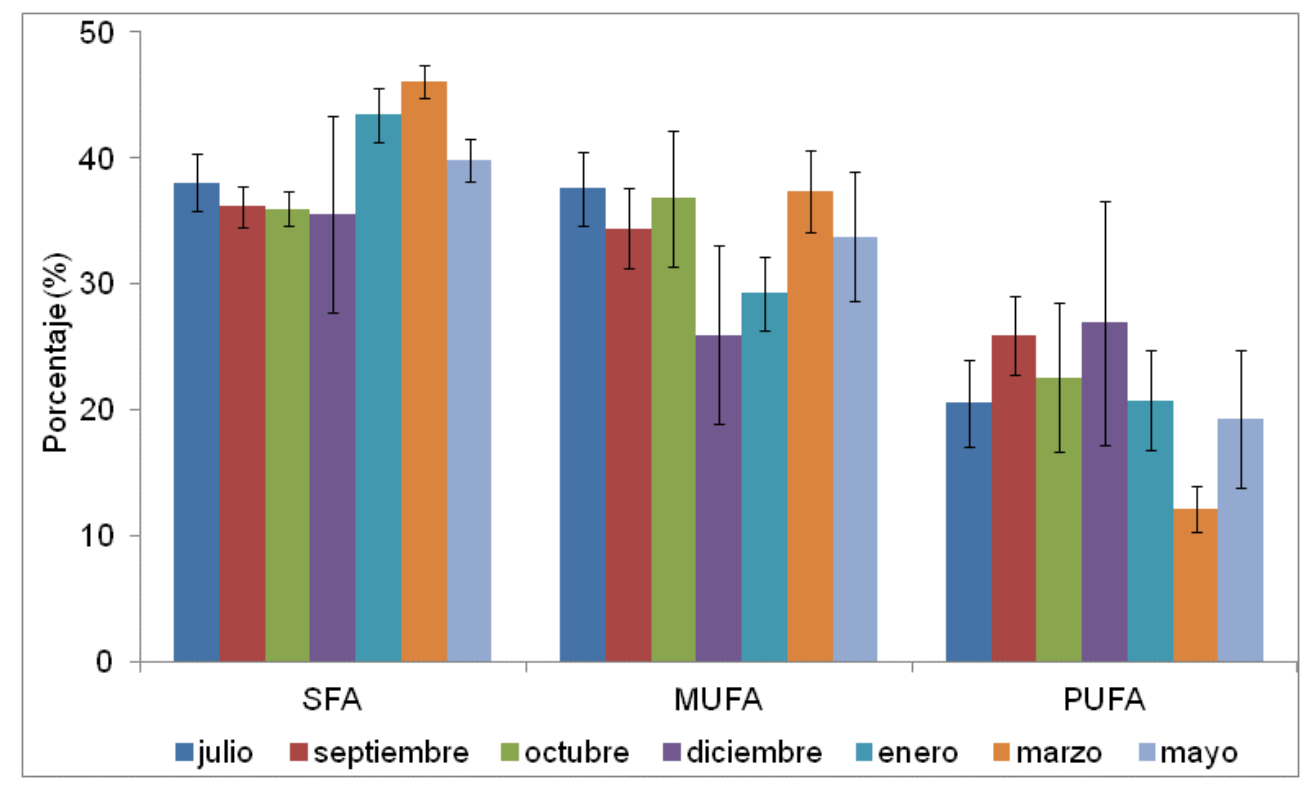

Figura III- 12: Variación anual del contenido total de SFA, Total de ácidos grasos saturados; $\Sigma$ MUFA, Total de ácidos grasos monoinsaturados; $\Sigma$ PUFA, Total de ácidos grasos poliinsaturados. *Las barras expresan el error standard de la media.

En la Figura III-12 se presenta la variación anual de ácidos grasos saturados (SFA), ácidos grasos mono-insaturados (MUFAs) y ácidos grasos poli-insaturados (PUFAs). Respecto al contenido total de SFA, el mayor contenido se observó durante los meses de enero a julio donde se encontraba en posdesove y reposo. En marzo alcanzó un máximo de $46.14 \pm 1.30 \%$. Entre septiembre y diciembre presentó una 
reducción a $35-36 \%$. Para los MUFAs se observó un menor contenido en diciembre (26\%) mientras que el resto de los meses aumentó a 36-37\%. El menor contenido de PUFAs se observó en los meses de enero a mayo entre 12 y $19 \%$ cuando los ejemplares se encontraban en posdesove e iniciando el reposo. Además se observó que la relación de n3/n6 fue elevada (6.27), por lo que el consumo del mismo permitiría mejorar el balance 20/1 de la relación n6/n3 que actualmente se incorpora en las dietas occidentales. Los expertos de FAO (1997) recomiendan consumir 5/1 de $n-6 / n-3$. Valores similares de PUFAs y de la relación $n 3 / n 6$, fueron descriptos por Huynh y col. (2007) en músculo de arenques del Pacífico durante el periodo de reposo y post desoves.

Tabla III- 4: Ácidos grasos de músculo de $B$. aurea (entre paréntesis se indica el número de muestras analizadas)

\begin{tabular}{|c|c|c|c|c|c|c|c|}
\hline $\begin{array}{l}\text { Ácido } \\
\text { Graso }\end{array}$ & $\begin{array}{c}\text { Julio } \\
\text { (9) }\end{array}$ & $\begin{array}{c}\text { Septiembre } \\
\text { (5) }\end{array}$ & $\begin{array}{c}\text { Octubre } \\
\text { (5) }\end{array}$ & $\begin{array}{c}\text { Diciembre } \\
\text { (7) }\end{array}$ & $\begin{array}{c}\text { Enero } \\
(10)\end{array}$ & $\begin{array}{c}\text { Marzo } \\
(6)\end{array}$ & $\begin{array}{c}\text { Mayo } \\
\text { (8) }\end{array}$ \\
\hline C14:0 & $\begin{array}{l}6.29 \pm \\
0.78^{b}\end{array}$ & $6.49 \pm 0.86^{\mathrm{bc}}$ & $\begin{array}{l}6.57 \pm \\
0.55^{\mathrm{bc}}\end{array}$ & $4.28 \pm 1.82^{a}$ & $\begin{array}{l}8.90 \pm \\
1.47^{d}\end{array}$ & $\begin{array}{l}8.33 \pm \\
1.10^{\text {cd }}\end{array}$ & $\begin{array}{l}\text { 7.03. } \pm \\
0.47^{\text {bcd }}\end{array}$ \\
\hline C16:0 & $\begin{array}{c}25.41 \pm \\
1.74^{\mathrm{a}}\end{array}$ & $24.55 \pm 1.61^{\mathrm{a}}$ & $\begin{array}{c}23.98 \pm \\
1.43^{\mathrm{a}}\end{array}$ & $\begin{array}{c}25.14 \pm 5.71 \\
a\end{array}$ & $\begin{array}{c}27.85 \pm \\
1.68^{\mathrm{a}}\end{array}$ & $\begin{array}{c}32.36 \pm \\
1.26^{\mathrm{b}}\end{array}$ & $\begin{array}{r}27.46 \pm \\
1.79^{\mathrm{a}}\end{array}$ \\
\hline C17:0 & $\begin{array}{l}2.98 \pm \\
0.39^{c}\end{array}$ & $2.13 \pm 0.65^{D}$ & $\begin{array}{l}2.19 \pm \\
0.47^{b}\end{array}$ & $\begin{array}{c}1.54 \pm 0.51 \\
\text { ab }\end{array}$ & $\begin{array}{c}1.75 \pm \\
03^{\mathrm{ab}}\end{array}$ & $\begin{array}{l}1.31 \pm \\
0.31^{a}\end{array}$ & $\begin{array}{l}1.71 \pm \\
0.39^{\mathrm{ab}}\end{array}$ \\
\hline C18:0 & $\begin{array}{l}3.38 \pm \\
0.52^{\text {ab }}\end{array}$ & $2.97 \pm 0.34^{\mathrm{a}}$ & $\begin{array}{l}3.25 \pm \\
0.28 \text { ab }\end{array}$ & $\underset{\text { cd }}{4.57 \pm 1.33}$ & $\begin{array}{l}4.95 \pm \\
0.31^{d}\end{array}$ & $\begin{array}{c}4.13 \pm \\
0.42^{\text {bcd }}\end{array}$ & $\begin{array}{c}3.65 \pm \\
0.52^{\mathrm{abc}}\end{array}$ \\
\hline$\Sigma$ SFA & $\begin{array}{c}38.05 \pm \\
2.26^{\mathrm{ab}}\end{array}$ & $36.15 \pm 3.46^{\mathrm{a}}$ & $\begin{array}{c}35.99 \pm \\
2.73^{a}\end{array}$ & $\begin{array}{c}35.54 \pm 7.77 \\
a\end{array}$ & $\begin{array}{l}43.45 \pm \\
2.15^{\mathrm{bc}}\end{array}$ & $\begin{array}{c}46.14 \pm \\
1.30^{c}\end{array}$ & $\begin{array}{r}39.86 \pm \\
1.72^{\text {ab }}\end{array}$ \\
\hline C16:1 n-7 & $\begin{array}{c}13.54 \pm \\
1.72^{\mathrm{d}}\end{array}$ & $\begin{array}{c}11.68 \pm 1.00 \\
\text { bcd }\end{array}$ & $\begin{array}{l}12.60 \pm \\
1.79^{\mathrm{cd}}\end{array}$ & $6.25 \pm 1.78^{\mathrm{a}}$ & $\begin{array}{l}10.76 \pm \\
2.15^{\mathrm{bc}}\end{array}$ & $\begin{array}{l}10.27 \pm \\
1.05^{\mathrm{bc}}\end{array}$ & $\begin{array}{l}9.13 \pm \\
1.72^{b}\end{array}$ \\
\hline C17:1 & $\begin{array}{l}2.50 \pm \\
0.50^{c}\end{array}$ & $1.79 \pm 0.48^{\mathrm{bc}}$ & $\begin{array}{c}1.64 \pm \\
0.86^{\mathrm{abc}}\end{array}$ & $0.81 \pm 0.45^{\mathrm{a}}$ & $\begin{array}{l}1.16 \pm \\
0.37^{\mathrm{ab}}\end{array}$ & $\begin{array}{l}0.91 \pm \\
0.17^{\text {ab }}\end{array}$ & $\begin{array}{l}0.81 \pm \\
0.78^{a}\end{array}$ \\
\hline C18:1 n-9 & $\begin{array}{l}18.58 \pm \\
2.70^{\text {ab }}\end{array}$ & $18.52 \pm 2.19^{\text {ab }}$ & $\begin{array}{c}22.08 \pm \\
4.09^{b}\end{array}$ & $\begin{array}{c}15.67 \pm 4.31 \\
\mathrm{a}\end{array}$ & $\begin{array}{c}15.57 \pm \\
2.00^{\mathrm{a}}\end{array}$ & $\begin{array}{c}23.08 \pm \\
3.07^{b}\end{array}$ & $\begin{array}{c}20.13 \pm \\
4.27^{\mathrm{ab}}\end{array}$ \\
\hline C20:1 n-9 & $\begin{array}{l}3.01 \pm \\
0.78^{\text {cd }}\end{array}$ & $2.43 \pm 0.49^{\mathrm{DC}}$ & $\begin{array}{l}0.51 \pm \\
0.16^{a}\end{array}$ & $\begin{array}{c}3.23 \pm 1.24 \\
\text { cd }\end{array}$ & $\begin{array}{l}1.77^{ \pm} \\
0.63^{b}\end{array}$ & $\begin{array}{l}3.08 \pm \\
0.69^{\mathrm{cd}}\end{array}$ & $\begin{array}{l}3.70 \pm \\
0.47^{d}\end{array}$ \\
\hline$\sum M U F A$ & $\begin{array}{c}37.63 \\
\pm 2.93^{c}\end{array}$ & $34.42 \pm 4.16^{\mathrm{bc}}$ & $\begin{array}{c}36.83 \pm \\
6.91^{c}\end{array}$ & $\begin{array}{c}25.97 \pm 7.11 \\
a\end{array}$ & $\begin{array}{c}29.26 \pm \\
2.88^{\text {ab }}\end{array}$ & $\begin{array}{c}37.34 \pm \\
3.25^{c}\end{array}$ & $\begin{array}{r}33.76 \pm \\
5.12^{\mathrm{bc}}\end{array}$ \\
\hline C18:2 n-6 & $\begin{array}{l}2.35 \pm \\
0.69^{c}\end{array}$ & $1.87 \pm 0.84^{\mathrm{bc}}$ & $\begin{array}{c}1.61 \pm \\
0.95^{\mathrm{abc}}\end{array}$ & $\underset{\mathrm{ab}}{1.02 \pm 0.49}$ & $\begin{array}{l}1.28 \pm \\
0.21^{\text {ab }}\end{array}$ & $\begin{array}{l}1.18 \pm \\
0.49^{\text {ab }}\end{array}$ & $\begin{array}{l}0.85 \pm \\
0.26^{a}\end{array}$ \\
\hline C18:3 n-3 & $\begin{array}{l}1.31 \pm \\
0.36^{\mathrm{bc}}\end{array}$ & $1.00 \pm 0.14^{\mathrm{ab}}$ & $\begin{array}{l}1.88 \pm \\
1.21^{\mathrm{c}}\end{array}$ & $0.46 \pm 0.19^{a}$ & $\begin{array}{c}1.13 \pm \\
0.41^{\mathrm{abc}}\end{array}$ & $\begin{array}{l}0.57 \pm \\
0.21^{\mathrm{ab}}\end{array}$ & $\begin{array}{l}0.56 \pm \\
0.34^{\text {ab }}\end{array}$ \\
\hline C18:4 n-3 & $\begin{array}{c}1.94 \pm \\
0.58^{\text {bcd }}\end{array}$ & $2.36 \pm 0.62^{\mathrm{de}}$ & $\begin{array}{l}2.95 \pm \\
0.77^{e}\end{array}$ & $0.60 \pm 0.18^{a}$ & $\begin{array}{l}1.82 \pm \\
0.20^{\text {cd }}\end{array}$ & $\begin{array}{c}1.31 \pm \\
0.35^{\mathrm{abc}}\end{array}$ & $\begin{array}{l}1.15 \pm \\
0.24^{\text {ab }}\end{array}$ \\
\hline
\end{tabular}




\begin{tabular}{|c|c|c|c|c|c|c|c|}
\hline C20:5 n-3 & $\begin{array}{l}5.98 \pm \\
1.18^{\mathrm{ab}}\end{array}$ & $8.09 \pm 1.27^{D}$ & $\begin{array}{l}6.85 \pm \\
1.12^{\mathrm{ab}}\end{array}$ & $\begin{array}{c}6.31 \pm 2.44 \\
\text { ab }\end{array}$ & $\begin{array}{l}6.15 \pm \\
1.79^{\mathrm{ab}}\end{array}$ & $\begin{array}{l}4.98 \pm \\
0.26^{a}\end{array}$ & $\begin{array}{l}7.93 \pm \\
1.50^{b}\end{array}$ \\
\hline C22:6 n-3 & $\begin{array}{l}9.01 \pm \\
1.90^{\mathrm{ab}}\end{array}$ & $12.60 \pm 1.38^{b c}$ & $\begin{array}{l}9.31 \pm \\
4.00^{\mathrm{ab}}\end{array}$ & $\begin{array}{c}18.68 \pm 7.77 \\
c\end{array}$ & $\begin{array}{l}10.14 \pm \\
2.96^{\mathrm{ab}}\end{array}$ & $\begin{array}{l}4.09 \pm \\
0.94^{a}\end{array}$ & $\begin{array}{l}8.80 \pm \\
3.99^{\mathrm{ab}}\end{array}$ \\
\hline$\sum$ PUFA & $\begin{array}{l}20.59 \pm \\
3.45^{\text {ab }}\end{array}$ & $25.93 \pm 4.25^{b}$ & $\begin{array}{c}22.61 \pm \\
8.05^{b}\end{array}$ & $\begin{array}{c}26.93 \pm 9.65 \\
b\end{array}$ & $\begin{array}{c}20.76 \pm \\
3.98^{a b}\end{array}$ & $\begin{array}{c}12.13 \pm \\
1.85^{\mathrm{a}}\end{array}$ & $\begin{array}{l}19.29 \pm \\
5.45^{\text {ab }}\end{array}$ \\
\hline$\sum n-3$ & 18.24 & 24.06 & 20.99 & 26.06 & 19.48 & 10.96 & 18.44 \\
\hline$\sum n-6$ & 2.35 & 1.87 & 1.61 & 1.02 & 1.28 & 1.18 & 0.85 \\
\hline $\begin{array}{c}\sum n-3 / \sum n- \\
6\end{array}$ & 7.76 & 12.86 & 13.03 & 25.54 & 15.21 & 9.28 & 21.68 \\
\hline
\end{tabular}

*Los resultados se presentan media \pm desviación standard. ${ }^{\star \star}$ Supraindices diferentes en una misma fila indican diferencias significativas entre las especies $(p<=0.05)$. $\sum$ SFA, Total de ácidos grasos saturados; $\Sigma$ MUFA, Total de ácidos grasos monoinsaturados; $\Sigma$ PUFA, Total de ácidos grasos poliinsaturados

\section{III.4. CONCLUSIONES}

Es una especie que presenta marcados cambios en su ciclo biológico, como se ven reflejados en los índices morfométricos y en los cambios químicos de la composición proximal del músculo. Dichos cambios están relacionados a un periodo de fuerte alimentación luego del periodo de desove. El periodo de reposo e inicio de maduración gonadal concuerda con los meses de alimentación y acumulación de grasa en el músculo abarcando el periodo de febrero a agosto. Esta acumulación de energía luego la destinará para la etapa de migración, maduración gonadal y desove. Por otro lado, la época de desove concuerda con un periodo de menor alimentación y mayor desgaste fisiológico abarcando desde septiembre-octubre a diciembre-enero (Acha y Macchi, 2000).

El aprovechamiento del músculo de Brevoortia aurea en lugar de especies blancas tradicionales, desde el punto de vista nutricional, es una buena opción para realizar productos saludables. Esto se debe al importante contenido de ácidos grasos poli-insaturados, especialmente docosahexaenoico (DHA), eicosapentaenoico (EPA) y oleico que presenta. Además el elevado contenido de n-3 frente al contenido de n-6 permite mejorar el balance nutricional en el consumo de ácidos grasos.

Es importante evaluar la composición de la materia prima en cada estadio, para definir en que tipo de producto es más apta tecnológicamente. De esta manera, las saraca pescadas entre octubre y mayo, que contienen un contenido de lípidos intermedio entre 3 y $10 \%$ podrían ser utilizadas para desarrollar productos tipo 
hamburguesas, nuggets. Mientras que las saracas capturadas entre julio y octubre, en la etapa final del reposo y al inicio de la maduración; y que presentan un mayor contenido de lípidos en músculo, podrían utilizar para desarrollar productos emulsionados del tipo de salchichas o pastas untables, aprovechando la variación estacional del contenido lipídico. 


\section{CAPITULO IV \\ ALMACENAMIENTO CONGELADO DE DESMENUZADO DE MÚSCULO DE SARACA: CAMBIOS EN LAS PROPIEDADES TECNOLÓGICAS DE LA PROTEINA}

IV.1. Congelación y almacenamiento congelado

A mediados del siglo XIX, se comenzó a utilizar el sistema de refrigeración mecánica para preservar alimentos del rápido deterioro y para finales del mismo siglo el congelado del pescado era una importante industria en los EEUU. Sin embargo la calidad inicial de los productos pesqueros congelados era muy deficiente y el proceso no era bien entendido. En el siglo XX tras el avance en los equipos de congelado, se observó que para mejorar la calidad del pescado congelado se debía congelar rápidamente. Se desarrollaron equipos como los congeladores de placa que aumentaban la velocidad de congelado por conducción. Durante las últimas décadas, desde el inicio del empleo del frío como sistema de conservación, se observó una mejora continua en el proceso, maquinarias y equipos, logrando mejorar la calidad del producto en las plantas de congelación y de esta manera competir en satisfacer las exigencias del mercado.

Según datos de la FAO (2011), en 2009, de la totalidad de pescado destinado para consumo humano a nivel mundial, el $28.1 \%$ se destinó para productos congelados; representando $34.793 \times 10^{6}$ tn de pescado, el $10.2 \%$ para curado, el 14.4 \% para conservas y el $46.8 \%$ para consumo fresco. Argentina en 2009 exportó productos de la pesca, en su gran mayoría congelados, por un valor de $1147.876 \times 10^{6}$ U\$D, ubicándose el país, en el puesto 25 de este rubro del mercado exportador (FAO, 2011).

La congelación de pescados y mariscos se realiza normalmente para controlar la oferta en relación a los rápidos cambios de la demanda del mercado, y así beneficiarse con los períodos de volúmenes de captura abundantes. La congelación es un método de conservación de alimentos que inhibe de manera parcial o total la actividad de:

- Enzimas

- Microorganismos

- Metabólismo.

El músculo congelado inevitablemente pierde alguno de los atributos de calidad del pescado fresco (Sigurgisladottir y col., 2000). Durante el almacenamiento se 
producen cambios en el olor, sabor, color y fundamentalmente en la textura. Dichas alteraciones dependerán del manejo previo del pescado, tanto a bordo de la flota pesquera como durante el procesamiento en planta hasta obtener el producto congelado. Se han publicado numerosos trabajos sobre el efecto de la congelación, analizando en particular el comportamiento bioquímico de las proteínas de músculo de pescado (Love y col., 1965; Gill, Keith y Smith-Lall, 1979; Hurling y McArthur, 1996; Refsgaard, Brockho y Jensen, 1999; Tironi, Tomás y Añon, 2010). Se ha establecido que la estructura del músculo fresco se modifica durante la congelación y posterior almacenamiento congelado. Estos cambios se deben al encogimiento de la fibras musculares que resultan del movimiento de agua hacia los espacios extracelulares que ocurren debido a la formación de hielo (Sigurgisladottir y col., 2000). La desnaturalización de las proteínas ha sido asociada con los cambios en la textura, observadas en el músculo de pescado almacenado congelado, tal como el "endurecimiento". También se encuentra relacionada con otras alteraciones funcionales tales como un aumento en la perdida de fluidos, cambios en las propiedades de unión y gelación (Tironi, 2005).

Numerosos aspectos relativos a las características del músculo de la saraca no fueron estudiados y se desconocen. En el presente Capítulo se caracterizará la composición química del músculo de esta especie con distintos estadios de madurez, para explorar la posibilidad de ser usado como una materia prima alternativa en reemplazo de las especies tradicionales. Asimismo, las proteínas de músculo de pescado sufren cambios químicos y físicos durante el almacenamiento congelado que resultan en una pérdida de calidad (Sotelo, Piñeiro y Pérez-Martín, 1995 y Ninan, Bindu y Joseph, 2010), lo que tiene una influencia directa en la factibilidad tecnológica de desarrollar nuevos productos. Por lo tanto, se pondrá énfasis, también, en el estudio de los cambios que produce el almacenamiento congelado del músculo desmenuzado de saraca en los siguientes parámetros: capacidad de retención de agua, pérdidas por "drip", Índice de la Actividad de la Emulsión, desnaturalización proteica y microestructura.

\section{IV.2. MATERIALES Y MÉTODOS}

IV.2.1. Preparación del desmenuzado de pescado

El trabajo experimental correspondiente a este Capítulo se realizó con individuos frescos del mismo estadio sexual y factor de condición eviscerado (III.2.2) Se seleccionaron cuatro estadios de madurez sexual: Julio (en reposo - Estadio V), fines 
de Agosto (madurez incipiente - Estadio II), Diciembre (desove - Estadio III) y Febrero (post-desove - Estadio IV) (Acha, 1999).

Las saracas (B. aurea) se capturaron entre diciembre 2008 (Figura IV-1) y agosto 2009 en las costas de la provincia de Buenos Aires, en la bahía de Samborombón, en cuatro épocas diferentes: diciembre 2008, febrero 2009, julio 2009 y agosto 2009.

El muestreo se realizó sobre un total de 11 cajones $(214.45 \mathrm{~kg})$ de pescado fresco. La pesca fue realizada con redes para pelágicos por pescadores profesionales y transportados en hielo hasta el Instituto Nacional de Investigación y Desarrollo Pesquero (INIDEP), Mar del Plata, Buenos Aires, Argentina. Luego del desembarque, el pescado fue acondicionado y almacenado en cajones con hielo. Se utilizaron ejemplares de talla mayor a los $32 \mathrm{~cm}$ lo que nos asegura trabajar solo con ejemplares adultos. Se utilizaron al menos 10 ejemplares en post rigor mortis para realizar la determinación del análisis proximal de cada estadio.

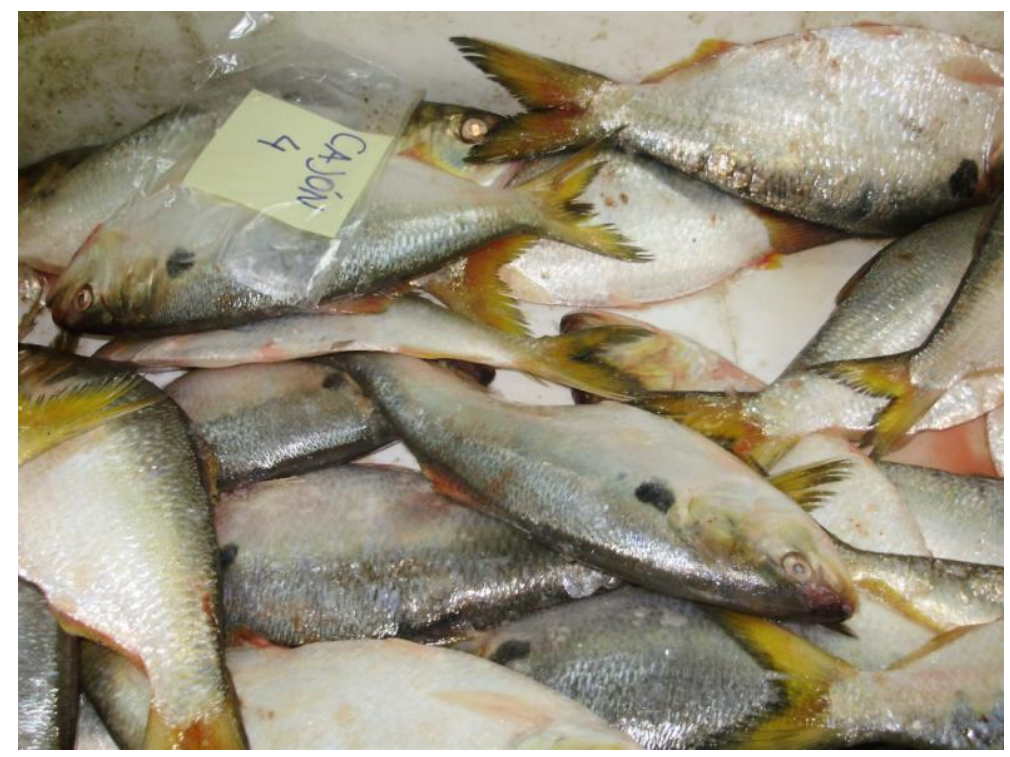

Figura IV- 1: Saracas capturadas en diciembre 2008.

Todos los pescados fueron eviscerados, lavados, fileteados, cuereados manualmente y para la obtención del desmenuzado sin espinas se utilizó una "Separadora de Piel y Espinas" Baader modelo 694 (Lübeck, Alemania) equipada con un tambor con perforaciones de $3 \mathrm{~mm}$ de diámetro. El proceso de separación se realizó en la planta Frigo Sur S.A. y se trabajó a temperatura entre 4 y $6 \stackrel{\circ}{\circ} \mathrm{C}$. El desmenuzado fue acondicionado en bolsas de plástico de baja permeabilidad al oxigeno Cryovac BB4L (Sealed Air Co., Buenos Aires Argentina), termoselladas, de $50 \mathrm{~g}$ cada una (Figura IV-2). 


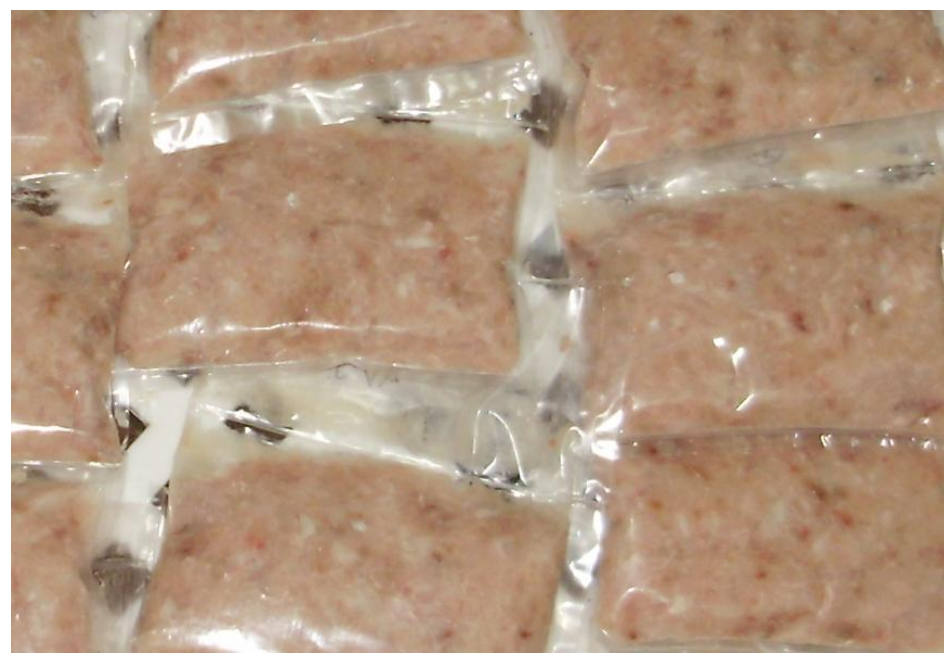

Figura IV- 2: Muestras acondicionadas en bolsas de baja permeabilidad Cryovac BB4L.

IV.2.2. Congelación de las muestras.

Las muestras envasadas se congelaron rápidamente a $-30^{\circ} \mathrm{C}$ en un congelador de placa, se mantuvieron a dicha temperatura por 24 hs y se transfirieron a un freezer a $-25^{\circ} \mathrm{C}$ donde se almacenaron durante 6 meses. Cada 2 meses $(0,2,4$ y 6 meses) se tomaron 13 bolsas que se utilizaron para evaluar la capacidad de retención de agua, la pérdida por "drip", el índice de actividad de la emulsión, la desnaturalización proteica y observar la microestructura del tejido. Asimismo se determinó la composición proximal de las muestras frescas para cada estadio.

IV.2.3. Análisis Proximal

Explicado en III.2.6.

IV.2.4. Capacidad de retención de agua (WHC)

La capacidad de retención de agua (WHC\%) se midió por sextuplicado utilizando un método de centrifugación, según la técnica descripta por Eide, Borresen y Strom (1982). Se colocaron $2 \mathrm{~g}$ de desmenuzado de músculo en un soporte, el que se introdujo en un tubo de centrífuga Falcon de $50 \mathrm{ml}$. Las muestras se centrifugaron (Combi-514R, HANIL Science Industrial, Corea) durante 5 minutos a $2500 \mathrm{rpm}$ y $10^{\circ} \mathrm{C}$, el líquido que no era retenido drenó a través de una membrana de poliéster de $400 \mu \mathrm{m}$ y se recolectó en el fondo del tubo (Figura IV-3). 
Cada muestra fue pesada antes y después de centrifugar, para determinar la pérdida de peso correspondiente.

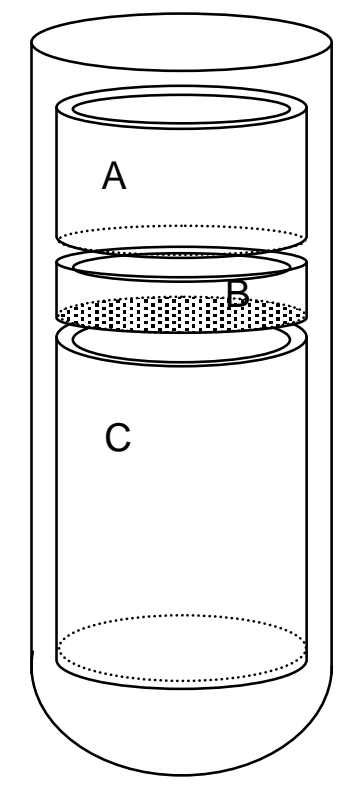

Figura IV- 3: Sistema de cilíndros de acrílico ( $\mathrm{A}$ y $\mathrm{C}$ ) con una

membrana (B) para la determinación de la capacidad de retención de agua de los desmenuzados de saraca almacenados congelados

\section{IV.2.5. Pérdidas por "drip"}

En este estudio, el término "drip" ha sido usado para describir el exudado producido luego del descongelado de las muestras de carne y se lo determinó siguiendo la metodología propuesta por Burgaard y Jorgensen (2010). Se colocaron cuatro muestras de aproximadamente $50 \mathrm{~g}$ dentro de recipientes adaptados con mallas de nylon de $8 \mathrm{~mm}$ (Figura IV-4), para permitir el drenado durante la descongelación de las mismas a $4{ }^{\circ} \mathrm{C}$ durante $16 \mathrm{~h}$. Las muestras se colocaron en la cámara refrigerada cubiertas por una película plástica para evitar la deshidratación superficial. Cada muestra fue pesada antes y después de descongelar. La medida se expresó como pérdida de fluido porcentual respecto al peso de muestra congelada inicial.

Pérdida por Drip $(\%)=($ peso del disco inicial - peso del disco final $) /$ peso del disco inicial) $\times 100$ 


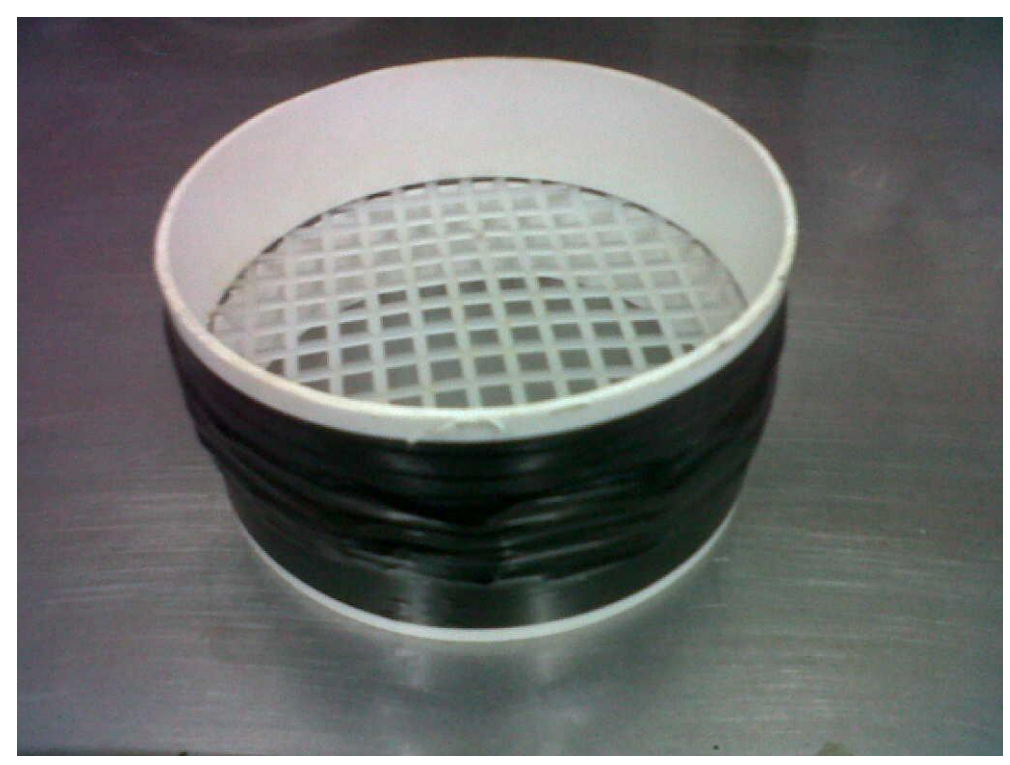

Figura IV- 4: Sistema para realizar la determinación del drip en muestras de $50 \mathrm{~g}$ de desmenuzado de saraca.

\section{IV.2.6. Desnaturalización Proteica}

Para estudiar la desnaturalización proteica se utilizó un calorímetro diferencial de barrido (DSC-Q100, TA Instruments, EEUU) que opera con nitrógeno líquido, perteneciente al CIDCA de La Plata. Se incluyó en este estudio muestras de tejido sin congelar como controles de los distintos estadios.

Las muestras (aprox. 15mg) se colocaron en cápsulas de aluminio, asegurándose un buen contacto entre la muestra y la base de la cápsula. Posteriormente se sellaron las cápsulas herméticamente. Se obtuvieron los correspondientes termogramas, sometiendo a las muestras a un programa de calentamiento entre $20^{\circ} \mathrm{C}$ y $120^{\circ} \mathrm{C}$, con una velocidad de calentamiento de $10^{\circ} \mathrm{C} / \mathrm{min}$. Se estimaron las máximas temperaturas asociadas a las transiciones térmicas así como la entalpía total de desnaturalización térmica de proteínas musculares al menos por triplicado (Radičević, Raicevic y Niketic, 2002).

\section{IV.2.7. Microestructura por microscopía de barrido electrónico (SEM)}

Se evaluó el efecto del almacenamiento congelado en la microestructura de las fibras musculares y la interacción entre las mismas utilizando un microscopio electrónico de barrido. Se fracturaron a mano pequeñas piezas de desmenuzado ( $5 \mathrm{x}$ $5 \times 5 \mathrm{~mm}$ ) para exponer la estructura interna del desmenuzado. El tejido se fijó inicialmente durante toda la noche en buffer de glutaraldehído en cacodilato de sodio. 
Las muestras fijadas fueron lavadas tres veces en buffer de cacodilato de sodio. Se deshidrataron en un gradiente de etanol al 70, 80, 90, 95 y 100\% durante 10 minutos. Por último las muestras fueron sumergidas en hexametildisilazano por 5 minutos y se dejaron secar a temperatura ambiente. Se montaron en placas de aluminio y se recubrieron con una delgada capa de oro/paladio en un Denton Vacuum desk II. Luego del recubrimiento, las muestras se observaron en un microscopio electrónico de barrido JEOL, modelo JSM 6460 LV a 15kv (JEOL, Tokyo, Japón) perteneciente a la Universidad Nacional de Mar del Plata.

IV.2.8. Propiedades de la emulsión

Se determinó el Índice Actividad de la Emulsión (IAE) y la Estabilidad de la Emulsión (EE) de la solución de proteínas sarcoplasmáticas y miofibrilares de músculo de saraca. El aislado proteico se extrajo y se analizó cada dos meses, durante el periodo de almacenamiento congelado para los desmenuzados de julio y diciembre.

Aislamiento de proteínas sarcoplasmáticas y miofibrilares de saraca

Para la extracción de la solución de proteínas de músculo de pescado se siguió la técnica de Borderías, Jimenez-Colmenero y Tejada (1985). Se homogenizaron $15 \mathrm{~g}$ de músculo descongelado de saraca (24hs en heladera $4^{\circ} \mathrm{C}$ ) con $60 \mathrm{ml}$ de solución $0.6 \mathrm{M}$ de $\mathrm{NaCl}$ a pH 7 , se homogenizó en un homogenizador de cuchillas, (Omni-Mixer; Omnimixer International, EEUU) a bajas revoluciones, durante 1 minuto en baño de hielo. Se llevó a volumen final de $360 \mathrm{ml}$ con la solución de 0,6M de $\mathrm{NaCl}$. Se dejó

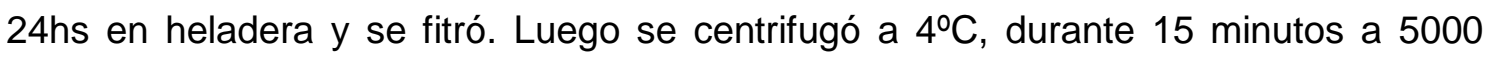
RPM en una centrifuga (Combi-514R, HANIL Science Industrial, Corea). De esta manera se separó la grasa y el tejido conectivo de la solución de proteínas sarcoplasmáticas y miofibrilares.

Se determinó el contenido de proteínas por método de Kjeldahl-Arnold-Gunning (factor $\mathrm{N}=6.25$ ) utilizando $20 \mathrm{ml}$ de solución proteica y siguiendo con la metodología explicada en III.2.6. Proteína

\section{Determinación del IAE}

Para el IAE se siguió la técnica de Palazolo, Mitidieri y Wagner (2003) basada en la técnica de Pearce y Kinsella (1978). A partir de la solución proteica obtenida en IV.2.8., se preparó una solución proteica de concentración $3 \mathrm{mg} / \mathrm{ml}$ con buffer fosfato $0.01 \mathrm{M} ; 0.6 \mathrm{M} \mathrm{NaCl} ; \mathrm{pH} 7.120 \mathrm{ml}$ de la solución proteica se emulsionó con $40 \mathrm{ml}$ de aceite de maíz a 18000RPM en un homogeneizador provisto de un rotor-estator 
(Omni-Mixer; Omnimixer International, EEUU) en baño de hielo. Rápidamente se traspasaron 3 alícuotas de $50 \mu \mathrm{l}$ de la emulsión en tubos con $5 \mathrm{ml}$ de solución de $0.1 \%$ SDS; $0.01 \mathrm{M}$ buffer fosfato; $0.6 \mathrm{M} \mathrm{NaCl} ; \mathrm{pH} 7$. Se invirtió cada tuvo tres veces y rápidamente se midió la absorvancia a $500 \mathrm{~nm}$ en un espectrofotómetro (modelo UV1800, Shimadzu Company, Japón). La absorbancia se midió inmediatamente, para la determinación del IAE, y a los 10 minutos luego de preparada la emulsión, para evaluar la estabilidad. EI IAE se calculó según:

$\mathrm{IAE}=4.606 \times A \times \mathrm{D} /(\mathrm{L} \times \mathrm{C} \times \varphi)\left(\mathrm{m}^{2} / \mathrm{g}\right)$

Ecuación IV-2

$\mathrm{EE}=4.606 \times \operatorname{At10} \times \mathrm{D} /(\mathrm{L} \times \mathrm{C} \times \varphi)\left(\mathrm{m}^{2} / \mathrm{g}\right)$

Ecuación IV-3

Donde:

$A=$ Absorbancia a $500 \mathrm{~nm}$ de la emulsión a tiempo 0

At10 = Absorbancia a $500 \mathrm{~nm}$ de la emulsión a los 10 minutos de realizada

$\mathrm{D}=$ Factor Dilución de 100

$\mathrm{L}=$ Camino óptico $0.01 \mathrm{~m}$

$\Phi=$ Volumen Aceite/Volumen Emulsión 40/160 =0.25

$\mathrm{C}=$ Concentración de la solución de proteínas $3 \mathrm{mg} / \mathrm{ml}\left(3000 \mathrm{~g} / \mathrm{m}^{3}\right)$

IV.2.9. Análisis Estadístico

Explicado en III.2.7.

\section{IV.3. RESULTADOS Y DISCUSIÓN}

IV.3.1. Composición en los diferentes estadios de madurez sexual

Los resultados correspondientes al análisis del músculo de Brevoortia aurea se observan en la Tabla IV-1, los mismos corresponden a cuatro estadios de maduración a lo largo del ciclo biológico.

Así como en el Capítulo III, nuevamente se observó que los ejemplares de julio (invierno) donde las gónadas se encontraban en reposo (Estadio $\mathrm{V}$ ), presentaron mayor contenido en lípidos $(20.6 \pm 7.0 \%)$ en músculo. Por otro lado los ejemplares de agosto presentaban sus gónadas en estadio II (maduración) y el contenido de lípidos en el músculo mostraba una tendencia a decrecer con respecto a julio (Estadio V), llegado diciembre - febrero (verano) los ejemplares se encontraban en desove y post- 
desove, y el contenido de lípidos en músculo alcanzó un mínimo (3.2 $\pm 2.7 \%$ ). Por otro lado, el contenido de proteínas se mantuvo constante con valores cercanos al $18 \%$.

\begin{tabular}{lllll}
\hline Estadio & Humedad & Lípidos & Proteínas & Cenizas \\
\hline V (julio) & $64.2 \pm 5.6^{\mathrm{b}}$ & $20.6 \pm 7.0^{\mathrm{a}}$ & $15.2 \pm 1.5^{\mathrm{b}}$ & $1.1 \pm 0.2^{\mathrm{b}}$ \\
II (agosto) & $63.4 \pm 1.9^{\mathrm{b}}$ & $19.4 \pm 2.6^{\mathrm{a}}$ & $18.6 \pm 0.9^{\mathrm{a}}$ & $1.3 \pm 0.3^{\mathrm{b}}$ \\
III (diciembre) & $78.7 \pm 2.8^{\mathrm{a}}$ & $3.2 \pm 2.7^{\mathrm{b}}$ & $18.6 \pm 1.4^{\mathrm{a}}$ & $1.7 \pm 0.1^{\mathrm{a}}$ \\
IV (febrero) & $74.1 \pm 0.5^{\mathrm{a}}$ & $7.1 \pm 0.6^{\mathrm{b}}$ & $18.4 \pm 0.3^{\mathrm{a}}$ & $1.3 \pm 0.1^{\mathrm{b}}$ \\
\hline
\end{tabular}

Tabla IV-1: Composición proximal del músculo de Brevoortia aurea en diferentes estadios de madurez sexual* (expresados como \% en base húmeda). *Valores promedio \pm desviación standard $(n=6)$. ** Supraíndices diferentes dentro de la misma columna indican que los valores medios difieren significativamente $(P<0.05)$

IV.3.2. Efecto del almacenamiento congelado en la desnaturalización proteica

El proceso de congelación y el almacenamiento congelado producen desnaturalización en las proteínas del músculo de pescado, la cual afecta su calidad. La intensidad en la desnaturalización depende de cada especie (Hastings y col., 1985; Tironi, Tomás y Añón, 2010) y del estado de madurez sexual en el que se encuentren (Paredi y Crupkin, 1997). Por lo tanto se utilizó calorimetría diferencial de barrido para determinar la extensión de desnaturalización de las proteínas miofibrilares y comparar los resultados con los obtenidos con tejido fresco.

En todas las muestras analizadas los termogramas fueron cualitativamente similares. Presentaron una endoterma bifásica, donde el primer pico corresponde a la temperatura de transición térmica de la miosina, las proteínas sarcoplasmáticas y el colágeno ( $\mathrm{TI})$, el segundo pico representa la temperatura de desnaturalización de la actina (TII). A modo de ejemplo en la Figura IV-5 a, b, c y d se muestran curvas correspondientes a los estadios de desove (diciembre), posdesove (febrero), reposo (julio) y maduración (agosto), respectivamente.

Con el fin de describir los termogramas, la temperatura máxima de los picos fue utilizada para representar la temperatura de la transición. Las entalpías parciales de desnaturalización de los componentes principales (miosina y actina) no se calcularon individualmente ante la dificultad de separar ambos picos correctamente, por ello se registraron sólo las entalpías totales de desnaturalización. El estadio biológico de las muestras no tuvo efecto sobre las temperaturas máximas del pico II (74.7 ${ }^{\circ} \mathrm{C}-77.6$ $\left.{ }^{\circ} \mathrm{C}\right)$ en el músculo fresco $(\mathrm{P}<0.05)$. Sin embargo $\mathrm{TI}$ del desmenuzado sin congelar 
presentó cambios durante el ciclo de desove, presentando un máximo en diciembre $\left(53.5^{\circ} \mathrm{C}\right)$ y un mínimo en julio $\left(51.4^{\circ} \mathrm{C}\right)$. La congelación provocó una disminución promedio de $0.4^{\circ} \mathrm{C}$ en el valor de $\mathrm{TI}$, y la entalpía total disminuyó en un $13 \%$ en comparación a la de las muestras sin congelar (Figura IV-6).
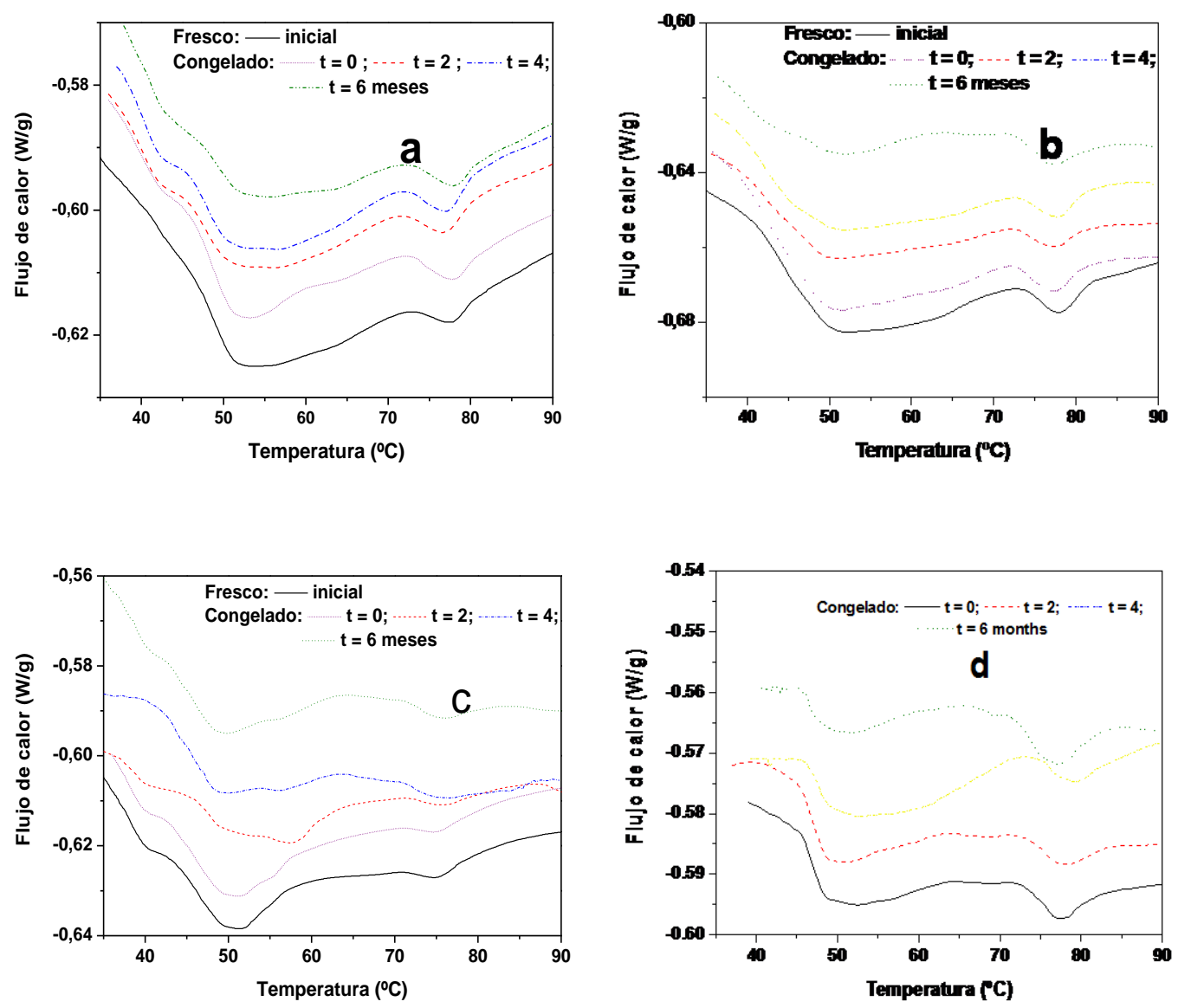

Figura IV- 5: Termogramas correspondientes a las transiciones de desnaturalización proteica en función del tiempo de almacenamiento congelado a -25 ${ }^{\circ}$ C. a. Diciembre. b. Febrero. c. Julio. d. Agosto. Fresco: — inicial. Congelado: $\mathrm{t}=0$ meses $;---\mathrm{t}=2$ meses, $-\cdot-\cdot-\mathrm{t}=4$ meses; $-\cdots-\cdots-\mathrm{t}=6$ meses

A medida que aumentó el tiempo del almacenamiento congelado el proceso de desnaturalización fue en aumento y se vio reflejado en la disminución de la entalpía de desnaturalización medida por DSC, hasta alcanzar un $60 \%$ del valor inicial luego de los 6 meses de almacenado. Sin embargo, ambos picos se pudieron observar incluso al final del experimento, sin presentar cambios en las temperaturas de las transiciones (Figura IV-5 a, b, c y d, Figura IV-7). 
La desnaturalización por congelamiento de actomiosina puede estar causada por la formación de puentes disulfuro, de hidrógeno y enlaces hidrofóbicos (Jiang, Hwang y Chen, 1988). Matsumoto (1980) informó sobre la formación de agregados en el músculo de pescado durante el almacenamiento congelado. Los resultados encontrados en este trabajo de Tesis concuerdan con los resultados encontrados por Schubring (1999) para Pollachius virens, quien reportó que el área de la endoterma bifásica disminuía a medida que el tiempo de almacenamiento aumenta.

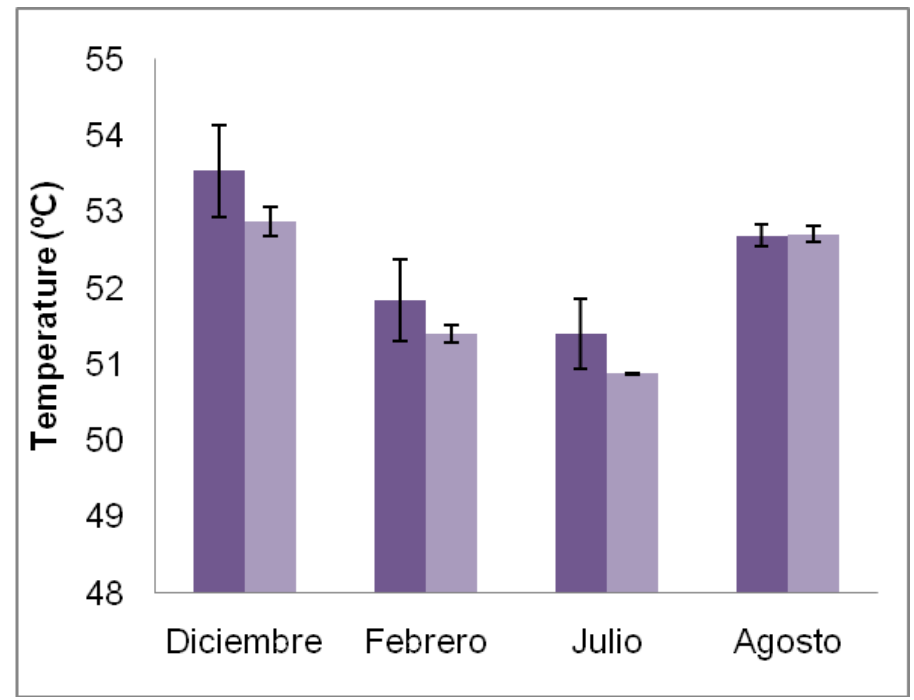

Figura IV- 6: Comparación de la temperatura del pico I antes y después de congelar (tiempo $=0$ ), de muestras capturadas en diferentes meses del año. Las barras expresan el error standard de la media.

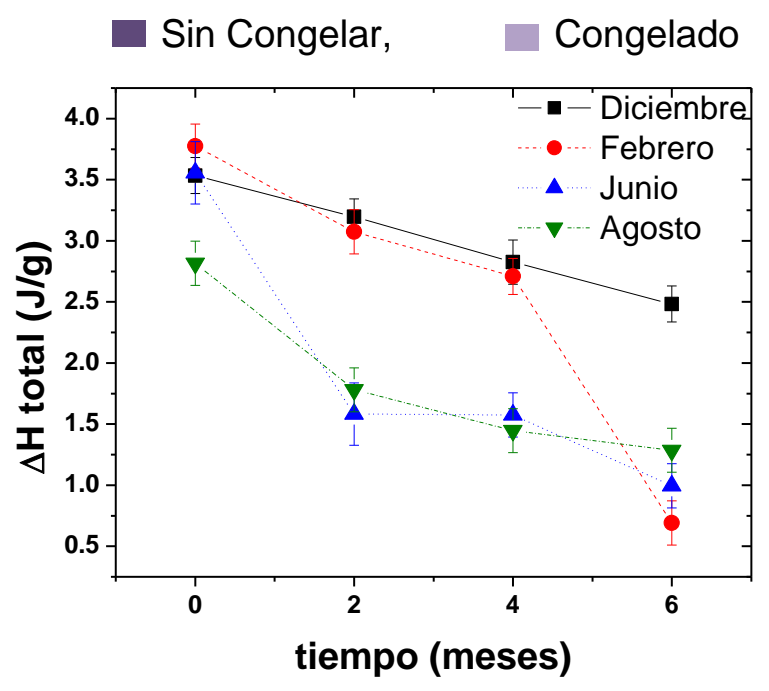

Figura IV- 7: Cambios en la entalpía de desnaturalización de las proteínas del músculo de saraca almacenado a $-25^{\circ} \mathrm{C}$ capturados a diferentes estados de maduración $\mathbf{D}$ Diciembre, - Febrero, $\boldsymbol{\Delta}$ Julio y $\boldsymbol{\nabla}$ Agosto. Las barras expresan el error standard de la media. 
IV.3.3. Cambios en la capacidad de retención de agua y pérdidas por "drip" debido al almacenamiento congelado

La capacidad de retener agua de las proteínas, es una propiedad que les permite retener líquidos a pesar del efecto de la gravedad o presión aplicada. Esta es una de las propiedades funcionales más importantes de las proteínas y esta capacidad de ligar agua es un factor limitante a la hora de desarrollar productos de origen proteico. La determinación de WHC y la pérdida de agua por drip permiten evaluar la interacción agua-proteína y determinar la funcionalidad de la proteína evaluada (Zhang, Mittal y Barbut, 1995; Anese y Gormley, 1996 y Zayas, 1997). A su vez a nivel comercial, la pérdida por goteo es un problema de tipo económico, que afecta principalmente a quien la comercializa. Reduce el peso de la carne y provoca una acumulación de líquido alrededor de ésta, de aspecto poco agradable, lo que ocasiona rechazo por parte del consumidor. Además, para el que procesa la carne, es una pérdida de proteína animal ya que a menudo se desecha el jugo producto del goteo (Morón-Fuenmayor y Zamorano-García, 2003) que se genera durante el proceso de descongelación.

En este trabajo se observó que la capacidad de retener agua disminuyó ligeramente, mientras que la pérdida por drip al descongelar las muestras aumentó a lo largo del almacenamiento congelado, tal como se observa en la Tabla IV-2. Sin embargo, la pérdida por drip se mantuvo por debajo del $2 \%$ indicando que la calidad de la proteína no varió significativamente durante el año.

Tabla IV- 2: Cambios en la capacidad de retención de agua (WHC) y pérdidas por "drip" en desmenuzado de tejido muscular de $B$. aurea a lo largo del almacenamiento congelado a $-25^{\circ} \mathrm{C}$.

\begin{tabular}{ccccc}
\hline $\begin{array}{c}\text { Tiempo de } \\
\text { almacenamiento } \\
\text { (meses) }\end{array}$ & \multicolumn{2}{c}{$\left(\mathrm{nHC}{ }^{*}(\%)\right.$} & \multicolumn{2}{c}{$\begin{array}{c}\text { Pérdidas por "drip" } \\
(\mathrm{n}=4)\end{array}$} \\
\cline { 2 - 5 } & Diciembre & Julio & Diciembre & Julio \\
\hline 0 & $82.7 \pm 2.9^{\mathrm{a}}$ & $80.0 \pm 1.8^{\mathrm{a}}$ & $0.76 \pm 0.01^{\mathrm{b}}$ & $0.01 \pm 0.001^{\mathrm{e}}$ \\
2 & $79.2 \pm 3.4^{\mathrm{a}}$ & $78.3 \pm 2.9^{\mathrm{a}}$ & $0.76 \pm 0.10^{\mathrm{b}}$ & $0.25 \pm 0.11^{\mathrm{d}}$ \\
4 & $64.1 \pm 2.4^{\mathrm{b}}$ & $76.4 \pm 6.0^{\mathrm{a}}$ & $0.77 \pm 0.11^{\mathrm{b}}$ & $0.54 \pm 0.02^{\mathrm{c}}$ \\
6 & $64.2 \pm 1.3^{\mathrm{b}}$ & $76.5 \pm 3.8^{\mathrm{a}}$ & $1.81 \pm 0.08^{\mathrm{a}}$ & $0.81 \pm 0.11^{\mathrm{b}}$ \\
\hline
\end{tabular}

*Los resultados se muestran como medias \pm desviación standard; el número de muestras analizado se da entre paréntesis. ${ }^{* *}$ Supraíndices diferentes para medias de la misma variable indican que los valores medios difieren significativamente $(P<0.05)$. 
En cuanto a la capacidad de retención de agua del tejido desmenuzado fresco previo a la congelación, se observaron valores medios de 90.00 ( \pm 2.04$) \%$ y 96.04 ( \pm 1.06) \% en diciembre y en julio respectivamente. Estas diferencias pueden estar atribuidas al período de desove del año. Nielsen y col. (2005) trabajaron con filetes frescos de arenque (Clupea harengus) y encontraron que la capacidad de retención de líquidos en otoño fue significativamente mayor que en primavera e invierno. Esta característica se la atribuye al estado de madurez de las gónadas.

Esta pérdida en la capacidad de retener agua, es atribuida a la desnaturalización de las proteínas miofibrilares y ha sido previamente informada por otros autores en diferentes especies marinas. Los factores que influyen la capacidad de retención de agua del músculo se pueden categorizar como factores internos o externos. Factores internos como por ejemplo la especie, la edad, el tamaño, el tipo de músculo, el contenido de grasa intramuscular y la condición del tejido post mortem. Factores externos son la alimentación, la estación del año, la ubicación de la captura y la manipulación luego de la muerte (Magnea, 2009). Magnea (2009) describió cambios en WHC en músculo de Gadus callarías, el cual aumenta durante el periodo de rigor mortis. Por lo cual periodos cortos de rigor mortis provocaría un menor descenso del $\mathrm{pH}$ lo que resultaría en un aumento de la retención de agua. A su vez las diferencias estacionales afectan el proceso de rigor mortis, la condición del músculo, la disminución del pH durante el rigor mortis y el WHC.

Magnea (2009) no observó cambios significativos en relación al drip y WPC durante el almacenamiento congelado en filetes de abadejo (Gadus morhua) y de carbonero (Pollachius virens). Manteniendose el drip entre 4 y $5 \%$ y entre 75 y $76 \%$ el WHC para pescado congelado inicial y almacenado durante 1 mes a $-25^{\circ} \mathrm{C}$. El aumento en el drip y la disminución en la WHC son, el resultado de cambios en la proteína que causan la alteración de sus propiedades funcionales. Esta pérdida de funcionalidad puede deberse a diversos factores de distinto origen como la velocidad de congelación que influye sobre el aumento en el tamaño de los cristales de hielo o bien a la desnaturalización por la vía enzimática que produce la formación de dimetilamina y formaldehido, que producen entrecruzamientos (cross-links) entre las proteínas, provocando una reducción de la solubilidad proteica, favoreciendo la agregación y generando por lo tanto una pérdida en las propiedades funcionales de las proteínas (Burgaard y Jorgensen, 2010; Gonçalves y col., 2008; Ruilova, 2008). 
IV.3.4. Estructura de las fibras de proteínas de músculo de pescado con microscopía electrónica de barrido - SEM

La observación de las muestras por SEM permite determinar el estado de la estructura, la disposición y la interacción de las fibras musculares. El tejido desmenuzado, almacenado por 6 meses presentó mayor número de agregaciones, interacciones y contracción, lo que provocó mayor resistencia del músculo a la fuerza de cizalla (Figura IV-8). Los cambios observados en la microestructura del músculo explican en parte la pérdida en la capacidad de retención de agua y el aumento en las pérdidas por drip durante el almacenamiento congelado. Otwell y Giddings (1980) reportaron que el tiempo de almacenamiento prolongado en calamar da como resultado deshidratación en las fibras y compresión debido al crecimiento de los cristales de hielo ubicados por fuera de las células. En consecuencia, el almacenamiento congelado causa deshidratación parcial de los espacios de las miofibrillas, volviendo a los miofilamentos más compactos, duros y posiblemente favoreciendo su entrecruzamiento.
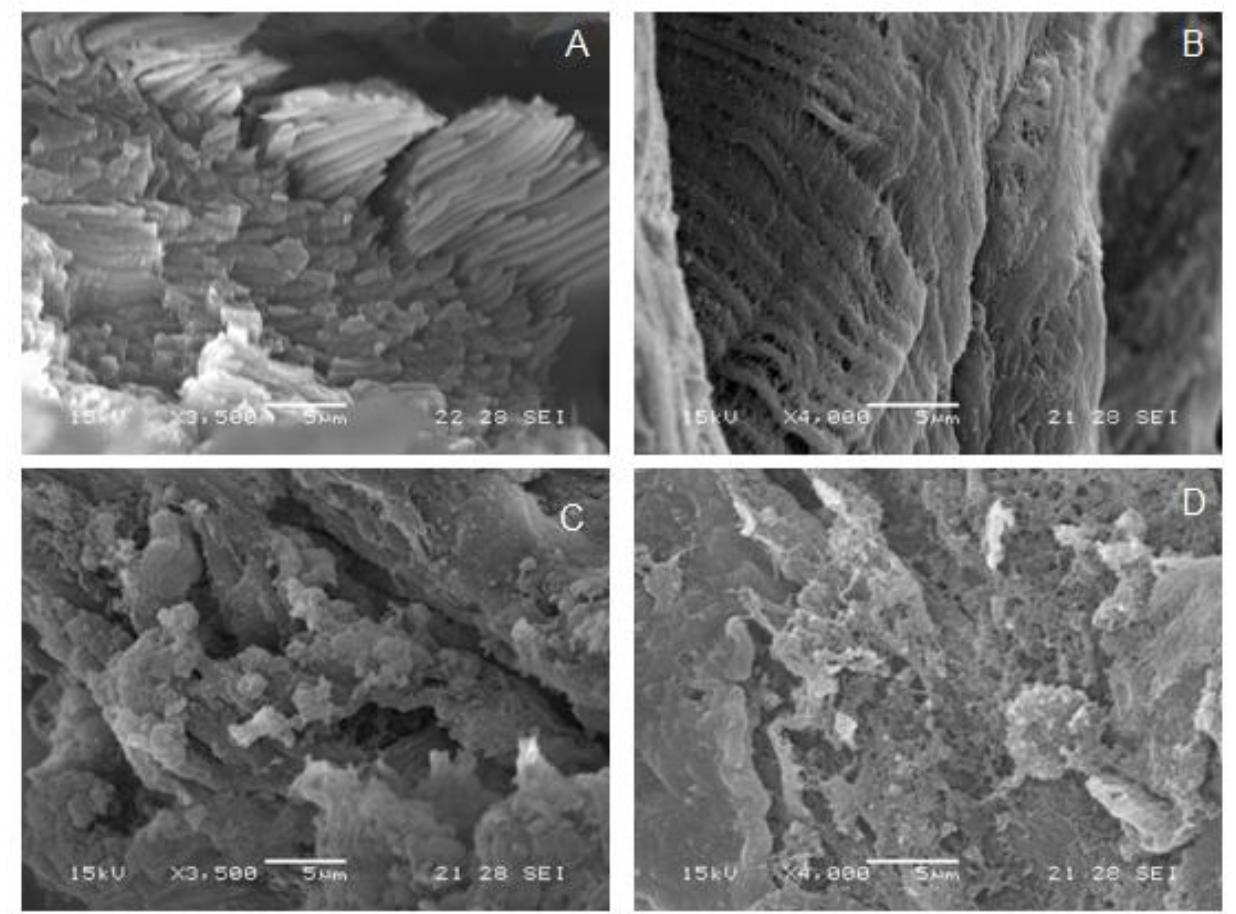

Figura IV- 8: Microscopía Electrónica de Barrido de músculo desmenuzado de Brevoortia aurea almacenado congelado a $-25^{\circ} \mathrm{C}$. A-B Inicio del almacenamiento, bar $=5 \mu \mathrm{m}$; C-D 6 meses de almacenamiento, bar $=5 \mu \mathrm{m}$.

Matsumoto (1980) propuso que durante las primeras etapas de conservación congelado, los filamentos de actomiosina se presentan agregados lateralmente y 
entrecruzados. Este entrecruzamiento y agregación de la actomiosina, tiene lugar en una disociación de la misma en actina f y miosina acompañada de una agregación de ambas proteínas. El endurecimiento homogéneo de las miofibrillas provocado por la congelación disminuiría la probabilidad de fractura a lo largo de las zonas $Z$ y los entrecruzamientos miofibrilares provocarían la disminución de la resolución de la fibra. Además podría estar influenciado por la descomposición por vía enzimática del óxido de trimetilamina (OTMA) en dimetilamina y formaldehido que es común en las especies marinas como los gadiformes.

\section{IV.3.5. Índice de actividad de la emulsión}

Las proteínas tienen la capacidad de formar emulsiones y esta propiedad juega un papel importante en sus diversas aplicaciones en alimentos. Varios factores y condiciones influyen en las propiedades de emulsificación, estos incluyen: característica estructural y química, por ejemplo el contenido y arreglo de los aminoácidos, peso molecular, regiones hidrofóbicas y condiciones que prevalecen en el medio (temperatura, $\mathrm{pH}$ y efectos iónicos). El músculo de pescado está compuesto por proteínas sarcoplasmáticas y proteínas miofibrilares mientras que el estroma forma parte del tejido conectivo. La carne de los animales de carne roja tienen una composición similar, aunque contienen más estroma que el pescado.

Las proteínas sarcoplasmáticas están formadas por muchos tipos de proteínas solubles en agua. El contenido de proteína sarcoplasmáticas del músculo de pescado varía con la especie, pero en general es más alta en pescados pelágicos tales como la sardina y la caballa e inferior en los demersales tales como el bacalao, la merluza o la los peces planos (Suzuki, 1987).

Estos polipéptidos también se conocen con el nombre genérico de miogeno; son fundamentalmente globulinas y albuminas pertenecientes a los sistemas que intervienen en el metabolismo celular, como el de la glucolisis, al igual que enzimas como las catepsinas, la creatina kinasa y la mioglobina. Estos grupos de proteínas se caracteriza por ser buenos agentes emulsificantes y por retener una gran cantidad de agua, lo que evita perdidas de humedad durante el proceso de cocción de los distintos productos cárnicos, tienen la capacidad de coagular y formar geles cuya textura es muy deseable en diversos alimentos.

Las proteínas miofibrilares son las que forman las miofibrillas, y están constituidas por varias proteínas. En el caso del pescado, la actina y la miosina son las proteínas con mayor relación en las propiedades funcionales y de la textura del 
músculo. Las propiedades funcionales del músculo tienen interés tecnológico y están relacionadas con los cambios a nivel de las proteínas miofibrilares.

La habilidad de las proteínas para emulsionar grasas es de gran importancia tecnológica, particularmente en la industria de los embutidos de pasta fina y productos similares. Las proteínas son moléculas anfifílicas con actividad surfractante y se ubican en la interfase agua-aceite. Esta habilidad es una propiedad funcional relacionada con las características de superficie de las moléculas. Varía entre las diferentes proteínas, incluso se ve afectada por el perfil de aminoácidos y la estructura que presenta la proteína, la concentración, la solubilidad de las proteínas, el pH, la fuerza iónica y la temperatura del medio (Terrejón Ramos, 1996). Hay una estrecha relación entre la capacidad de emulsionar, la viscosidad y la hidrofobicidad superficial de las poteínas (Mohan y col., 2008).

Para analizar los datos de IAE obtenidos se consideraron tres factores: el momento de la captura correspondiente al estadio de reposo y desove del ciclo biológico (julio y diciembre respectivamente), el tiempo de almacenamiento del desmenuzado $(0,2,4$ y 6 meses) y el tiempo transcurrido desde la preparación de la emulsión ( 0 y 10 minutos). El análisis de varianza indicó que tanto el momento de la captura como el tiempo transcurrido desde la preparación de la emulsión tuvieron un efecto significativo en los valores de IAE, así también como todas las interacciones dobles y la interacción triple. El tiempo de almacenamiento no tuvo un efecto significativo en esta propiedad, ya que los IAE de los desmenuzados de julio y diciembre no presentaron diferencias significativas durante los 6 meses de almacenamiento congelado.

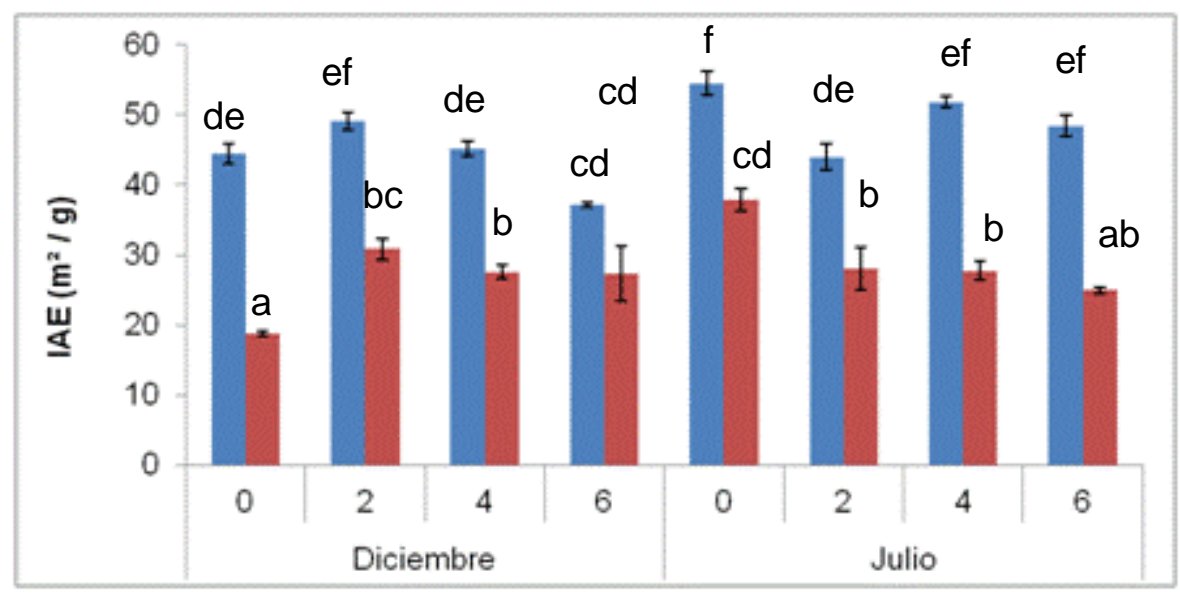

Figura IV- 9: IAE de proteínas de músculo de pescado

(sarcoplasmaticas+miofibrilares) durante su almacenamiento congelado a $-25^{\circ} \mathrm{C}$.

$(n=6)$. Los resultados expresados media + desviación standard. $t 0=\square t 10=\square$. Medias con letra diferente son significativamente diferentes $(P<0.05)$. 
Terrejon Ramos (1996) observó que tanto en filetes como en desmenuzado de bacalao (Gadus morhua), no presentaba diferencias significativas en IAE durante 36 semanas de almacenamiento congelado. La estabilidad de la proteína para formar emulsiones durante 6 meses de almacenamiento congelado puede deberse a la disponibilidad de los grupos hidrofílicos-hidrofóbico que presentan las moléculas de proteína.

En cambio, los IAE observados al cabo de 10 minutos presentaron una disminución significativa (Figura IV-9). Se observó que las emulsiones realizadas con el desmenuzado de julio presentaron valores de IAE mayores que el desmenuzado de diciembre, a lo largo del almacenamiento congelado. Las muestras al inicio del almacenamiento presentaron valores de $I A E$ t0 $=54.4, \mathrm{t} 10=37.8$ en desmenuzado de julio y $I A E$ t $0=44.4$, $\mathrm{t} 10=18.7$ en desmenuzado de diciembre. Al finalizar el sexto mes de almacenamiento congelado, el comportamiento del IAE no presentó diferencias significativas, los resultados fueron $\mathrm{t} 0=48.3$ y $\mathrm{t} 10=24.9$ en el desmenuzado del mes de julio y $\mathrm{t} 0=37.2$ y $\mathrm{t} 10=27.5$ en el desmenuzado de diciembre.

\section{IV.4. CONCLUSIONES}

La composición del músculo de Brevoortia aurea presenta cambios estacionales importantes en el contenido de lípidos y humedad, en relación al ciclo reproductivo de la especie. Cuando la especie se encuentra biológicamente en reposo, y sus órganos sexuales no se encuentran desarrollando ovocitos ni espermatocitos, el contenido de lípidos en músculo alcanza el valor máximo de $20 \%$ y mientras que el contenido de humedad llega a valores mínimo (63\%). A medida que la especie comienza a desarrollar sus órganos sexuales y se prepara para la época de puesta, el contenido de lípidos en músculo disminuye hasta el 3\%, mientras que la humedad aumenta significativamente hasta alcanzar valores de $78 \%$. El consumo de lípidos del músculo de pescado está asociado a la necesidad biológica que presentan las especies para desarrollar tanto los órganos sexuales, como así también el esfuerzo energético requerido para migrar a las zonas de desove. El contenido de proteínas y ceniza no varía significativamente a lo largo del ciclo.

Si bien el contenido de proteína no varía durante el ciclo biológico, se observaron diferencias a través de los termogramas obtenidos por DSC en desmenuzado fresco en los distintos estadios. Se encontró que en diciembre (desove) presenta un pico máximo asociado a la desnaturalización de miosina, proteínas sarcoplásmicas y colágeno a $53.5^{\circ} \mathrm{C}$, mientras que para julio dicha temperatura fue inferior $\left(51.4^{\circ} \mathrm{C}\right)$. El almacenamiento congelado a $-25^{\circ} \mathrm{C}$, provocó la desnaturalización de las proteínas de músculo, influyendo en las propiedades funcionales y la estabilidad 
de las mismas, la que se evidenció en una disminución del cambio entálpico total a medida que aumentó el tiempo de almacenamiento. Esta desnaturalización se vio reflejada también en la disminución de la capacidad de retención de agua (WHC) y en el aumento de las pérdidas por drip tanto en los desmenuzados de julio como de diciembre. A su vez, las imágenes obtenidas por SEM mostraron cambios en la estructura, disposición e interacción de las fibras musculares. Al final del almacenamiento se observaron estructuras de agregación entre fibras que explicarían en cierta medida las pérdidas en la funcionalidad de las proteínas en relación al WHC y al drip. En cambio, el índice de actividad de la emulsión no varió a lo largo del almacenamiento congelado de las muestras de diciembre y julio. Indicando que las muestras, a pesar de presentar desnaturalización, son estables para formar emulsiones a lo largo del almacenamiento congelado.

Si bien la desnaturalización de las proteínas es inherente al proceso de congelación y a lo largo del almacenamiento congelado, el problema se puede atenuar optimizando el mecanismo de transporte, el almacenamiento y los tiempos de procesamiento para la obtención de productos. También es importante seleccionar el equipo de congelación adecuado para reducir los tiempos de congelación. La mejor técnica es congelar rápido, así minimizar la formación de cristales de hielo y de esta manera reducir las pérdidas por drip y WHC. Así, se podría utilizar la saraca como materia prima de excelente calidad nutricional en el desarrollo de nuevos productos, ampliar el mercado y obtener una mayor rentabilidad de los productos realizados con esta materia prima. 


\section{CAPITULO V \\ ALMACENAMIENTO CONGELADO DE DESMENUZADO DE MÚSCULO DE SARACA: EFECTO DEL AGREGADO DE ANTIOXIDANTES}

\section{V.1. Oxidación de los lípidos durante el almacenamiento congelado}

En los Capítulos anteriores se observó que Brevoortia aurea es una especie rica en lípidos durante el mes de julio (20\%), mientras en diciembre alcanza un mínimo (3\%). Nutricionalmente es una buena fuente de proteína y de ácidos grasos esenciales. También se observó que durante los 6 meses de almacenamiento congelado, si bien presentó un cierto grado de desnaturalización de sus proteínas, no perdió en forma significativa las propiedades funcionales tales como su capacidad de retener agua, formar emulsión, etc. Por lo cual podemos decir, que el desmenuzado de saraca congelado a -25ㄷ $\mathrm{C}$ presentó una buena calidad y estabilidad de sus proteínas musculares durante 6 meses de almacenamiento a dicha temperatura. Esto nos permite considerarlo como una buena opción conservarlo congelado y utilizarlo como materia prima para el desarrollo de productos a base de desmenuzado de pescado. No obstante, no debemos olvidar que la saraca presenta un alto contenido de ácidos grasos poli-insaturados a lo largo del año, los cuales son susceptibles a la oxidación. Es por ello que es necesario evaluar la incorporación de algún agente protector de la misma.

Como hemos visto en el Capítulo 1, se pueden incorporar a los alimentos antioxidantes de diversos orígenes, ya sean sintéticos o naturales. La tendencia mundial es reducir el uso de los antioxidantes sintéticos por sus comprobados efectos nocivos para la salud y promover el uso de los naturales. El empleo de antioxidantes naturales es una alternativa más saludable respecto a los sintéticos, si bien estos últimos son muy eficientes y han sido tradicionalmente usados para controlar el deterioro en alimentos. El empleo de antioxidantes naturales puede, además, reforzar la actividad de los sistemas antioxidantes endógenos aportando una protección extra al estrés oxidativo. Los antioxidantes naturales provienen de diversos orígenes (plantas, hierbas, frutos) y están en continuo estudio (Pinelo, 2003; Garrido, 2007; Conde, 2009).

Debido al elevado contenido de PUFA en el músculo de pescado, los productos marinos de especies grasas son muy susceptibles a la pérdida de calidad debido a la oxidación lipídica, incluso durante el almacenamiento a muy bajas temperaturas. A su vez, es mayor el efecto de la oxidación en los productos elaborados con músculo 
desmenuzado de pescado ya que los lípidos al quedar más expuestos al oxigeno circundante pueden oxidarse con mayor facilidad. Por lo tanto, la oxidación se vuelve un proceso de deterioro acelerado, provocando cambios de color, olor y sabor. Así, la acumulación de productos secundarios de la oxidación son los responsables de desarrollo de color amarillo oscuro en la capa superficial y subsecuentemente en profundidad de las capas del músculo (Balev, 2009).

Al incorporar antioxidantes en productos de la pesca estos pueden actuar por diversos caminos, como secuestrante de iones metálicos, barriendo radicales y descomponiendo peróxidos. En alimentos los antioxidantes inhiben la peroxidación de los lípidos, interfiriendo en la formación de hidroperóxidos conjugados de productos primarios de la oxidación y los compuestos volátiles productos secundarios de la oxidación.

En este Capítulo se aborda el efecto del agregado de diferentes antioxidantes naturales (extracto de uva y tocoferoles) frente al uso de un antioxidante sintético (terbutil hidroxi quinona, BHTQ) en desmenuzado de saraca. Se busca evaluar entre ambas opciones de antioxidantes naturales, cuál se comporta mejor en la prevención de la oxidación de los lípidos del desmenuzado almacenado congelado, considerando también la posibilidad de un comportamiento diferente según el estadio sexual de los ejemplares capturados.

Trabajos previos demostraron que el antioxidante de extracto de uva es rico en cantidad y calidad de polifenoles. Los polifenoles de uva blanca son considerados potenciales antioxidantes y se dividen en dos grupos, los extraíbles (flavonoles como quercitin, catequinas, eipocatequinas) y los no extraíbles (proactociandinas y taninos) ambos grupos muestran efectos positivos en el campo de la nutrición y la salud (Sánchez-Alonso y col., 2008). La capacidad antioxidante de los polifenoles ha sido bien estudiada, tanto para lípidos en productos naturales como para modelos de lípidos. Los flavonoides actúan como antioxidantes, donando electrones y parando la cadena de los radicales (Grosso y col., 2013). Además los flavonoles de uva retardan la oxidación ya que pueden quelar a los metales promotores de la oxidación de los lípidos (Pazos y col., 2006).

\section{V.2. MATERIALES Y MÉTODOS}

V.2.1. Material utilizado.

El ensayo se realizó con saracas frescas capturadas en las costas de la provincia de Buenos Aires, en la bahía de Samborombón en julio y diciembre de 2009. El pescado fresco fue donado por la Pesquera Pagos de Santos y desembarcado en el 
puerto de Gral. Lavalle. Se utilizaron 4 cajones (110kg) en Julio y 3 cajones $(88 \mathrm{~kg})$ en Diciembre. El pescado desembarcado fue acondicionado en abundante hielo y transportado rápidamente hasta el Instituto Nacional de Investigación y Desarrollo Pesquero (INIDEP), Mar del Plata, Buenos Aires, Argentina. Los ensayos fueron realizados con ejemplares adultos de saraca de talla mayor a $32 \mathrm{~cm}$.

\section{V.2.2. Preparación del pescado}

Una vez recibido el pescado en el laboratorio de muestreo del INIDEP, se prepararon inmediatamente los filetes y se determinó el rendimiento de la operación como:

Rendimiento (\%):

((Peso Pescado Total- Peso desmenuzado)/ Peso Pescado Total) x 100

Ecuación V-1

\section{V.2.3. Preparación del desmenuzado}

Para la obtención del desmenuzado se siguió la metodología explicada en IV.2.1, utilizando una separadora Baader 694. Luego se procedió a la incorporación de diferentes antioxidantes, en forma inmediata a medida que se generaba el desmenuzado. Se evaluaron 4 formulaciones diferentes, dos de ellas contenían antioxidantes naturales (extracto de uva o tocoferoles naturales), la tercera un antioxidante sintético (BHTQ) y la cuarta no tuvo agregado de antioxidantes para utilizarse como control. La experiencia se realizó con los desmenuzados de los diferentes estadios de julio y diciembre. Los antioxidantes y dosis utilizadas se presentan en la Tabla $\mathrm{V}-1$.

En este trabajo, las dosis utilizadas se seleccionaron siguiendo resultados observados en bibliografía y en función de ensayos previos en trabajos del grupo. En todos los casos se trabajó dentro de los límites máximos permitidos y/o recomendados por la USDA, FDA, OMS y siguiendo lo establecido en el Código Alimentario Argentino (CAA).

El extracto de semillas de uva fue provisto por la empresa Indena de Francia; se incorporó al producto en una proporción de 700ppm, para alcanzar una dosis de catequinas de 100 ppm, ya que en trabajos previos esta concentración de catequinas era efectiva para reducir la oxidación de los lípidos en músculo de pescado (Tang y col., 2001; Maqsood y Benjakul, 2009; Pazos y col., 2010 y Brewer, 2011). 
Tabla V- 1: Composición y dosis de los antioxidantes utilizados en desmenuzados de saraca capturadas en julio y diciembre.

\begin{tabular}{|c|c|c|c|c|}
\hline Antioxidante & $\begin{array}{l}\text { Nombre } \\
\text { Comercial }\end{array}$ & Composición & $\begin{array}{l}\text { Dosis } \\
\text { Evaluada }\end{array}$ & $\begin{array}{l}\text { Dosis } \\
\text { compuesto } \\
\text { activo }\end{array}$ \\
\hline $\begin{array}{l}\text { Extracto de } \\
\text { semillas de } \\
\text { Uva }\end{array}$ & $\begin{array}{l}\text { Leucoselect@- } \\
\text { Indena }\end{array}$ & $\begin{array}{l}\text { Leucocianidinas } 97 \% \\
\text { Catequina+epicatequina } \\
13.4 \%\end{array}$ & $\begin{array}{l}700 \text { ppm } \\
\text { por kg de } \\
\text { pescado }\end{array}$ & $\begin{array}{l}100 p p m \text { de } \\
\text { catequinas }\end{array}$ \\
\hline $\begin{array}{l}\text { Mezcla de } \\
\text { Tocoferoles }\end{array}$ & $\begin{array}{l}\text { Tocoferol 70\% } \\
\text { AOMsa }\end{array}$ & $\begin{array}{l}64 \% \text { de no a Tocoferol } \\
\text { a } 6.46 \% \\
\text { ү } 46.20 \% \\
\delta 17.74 \%\end{array}$ & $\begin{array}{l}1000 \text { ppm } \\
\text { por kg de } \\
\text { pescado }\end{array}$ & $\begin{array}{l}\text { 700ppm de } \\
\text { Tocoferoles }\end{array}$ \\
\hline BHTQ & $\begin{array}{l}\text { Terbutil- } \\
\text { hidroxi- } \\
\text { quinona } \\
\text { Merck }\end{array}$ & BHTQ 97\% & \multicolumn{2}{|c|}{$\begin{array}{l}\text { 150ppm en relación al } \\
\text { contenido de grasa en } \\
\text { desmenuzado. }\end{array}$} \\
\hline
\end{tabular}

En el caso de los tocoferoles se utilizó la mezcla al 70\% provista por la empresa AOM S.A. de Argentina. La dosis utilizada fue de 1000 ppm, conteniendo 700 ppm de $\alpha, y$ y $\delta$ tocoferoles. En trabajos previos del grupo, se utilizó esta dosis y se observaron buenos resultados frente a la oxidación de los lípidos en hamburguesas de carnes rojas enriquecidas con ácidos grasos poli-insaturados (Pennisi y col., 2010). En todas las normativas consultadas, tanto en el caso del extracto de semillas de uva como de los tocoferoles no hay límite en su uso, son considerados por la USDA y FDA como compuestos GRAS (generalmente reconocidos como seguro) y se pueden incorporar sin límite en cuanto se sigan las Buenas Prácticas de Manufactura (BPM).

Con respecto al antioxidante sintético (BHTQ), se utilizó una dosis de 150 ppm en relación al contenido total de lípidos del alimento, de esta manera se trabajo por debajo del límite permitido para este compuesto que es de 200 ppm (FSIS, 2007).

\section{V.2.4. Incorporación de antioxidantes en el desmenuzado de pescado}

Se prepararon soluciones etanólicas (etanol absoluto, Merck) en las dosis determinadas de cada antioxidante. El antioxidante se incorporó con un vaporizador al desmenuzado a medida que éste se obtenía. Luego se homogenizó durante 1 minuto. Se prepararon 45 bolsas con $50 \mathrm{~g}$ de muestra para cada antioxidante y en cada periodo analizado (Julio y Diciembre). Se realizó el mismo procedimiento para las 
muestras control, donde sólo se incorporó etanol con un vaporizador y se homogenizó de igual manera que las muestras con antioxidante. Se utilizaron bolsas de baja permeabilidad al oxigeno Cryovac (BB4L, permeabilidad al $\mathrm{O}_{2}: 35 \mathrm{~cm}^{3} / 24 \mathrm{~h} / \mathrm{m}^{2} / 105 \mathrm{~Pa}$, y permeabilidad al $\mathrm{CO}_{2}: 150 \mathrm{~cm}^{3} / 24 \mathrm{~h} / \mathrm{m}_{2} / 105 \mathrm{~Pa}$ ) provistas por Sealed Air Co., Buenos Aires, Argentina. Para estos ensayos se utilizó un total de $18 \mathrm{~kg}$ de desmenuzado fresco de saraca para los dos periodos evaluados.

\section{V.2.5. Congelación de las muestras}

Explicado en IV.2.2.

\section{V.2.6. Oxidación lipídica}

Para la determinación de la oxidación lipídica se utilizó el método del ácido tiobarbitúrico el cual reporta las sustancias reactivas al TBA (TBARS), según las modificaciones propuestas por Tironi, Tomás y Añón, (2007). Este análisis se realizó por cuadruplicado sobre $2 \mathrm{~g}$ de muestras elegidas al azar. Para precipitar la proteína presente y solubilizar las TBARS se usó ácido tricloroacético (TCA) $10 \%$ y se colocó en baño de agua-hielo, homogeneizando la mezcla durante 30 segundos en Omnimixer (Omni-Mixer; Omnimixer International, EEUU) a baja velocidad.

Luego se filtró por papel. Se tomaron $2 \mathrm{ml}$ de filtrado y se colocaron en un tubo con $2 \mathrm{ml}$ de reactivo TBA $0.5 \%$ (preparado en agua el día de uso y sonicado 30 minutos), dejando reaccionar en baño termostático a $70{ }^{\circ} \mathrm{C}$ durante 30 minutos. Luego, se enfrió bajo canilla y se midió la absorbancia (A) a $532 \mathrm{~nm}$ en un espectofotómetro (UV1800, Shimadzu Company, Japón).

Las TBARS se expresaron como mg de malonaldehido (MDA)/kg producto:

$$
\text { № TBARS }=\mathrm{mg} \mathrm{MDA} / \mathrm{kg} \text { producto }=\frac{\mathrm{A}_{532} \times \mathrm{M} \times \mathrm{Va} \times \mathrm{Ve} \times 1000}{\mathrm{E} \times \mathrm{L} \times \mathrm{m}} \quad \text { Ecuación } \mathrm{V}-2
$$

Donde:

M: masa molecular del malonaldehído $(72 \mathrm{~g})$

Va: volumen alícuota $(2 \mathrm{ml})$

Ve: volumen extracto $(15 \mathrm{ml})$

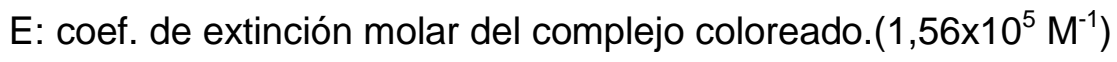

L: camino óptico $(1 \mathrm{~cm})$

m: masa de muestra 
Las determinaciones de TBARS se realizaron cada dos meses hasta alcanzar los 6 meses de almacenamiento congelado.

\section{V.2.7. Color}

Las mediciones de color se llevaron a cabo con un colorímetro triestímulo Minolta CR-400 (Minolta CR-400, Minolta Corp., Ramsey, New Jersey, USA). Este equipo es un analizador compacto triestímulo del color reflejado por superficies, el cual consta del respectivo cabezal de medida (área de medición de $8 \mathrm{~mm}$ de diámetro) y un procesador de datos DP-301.

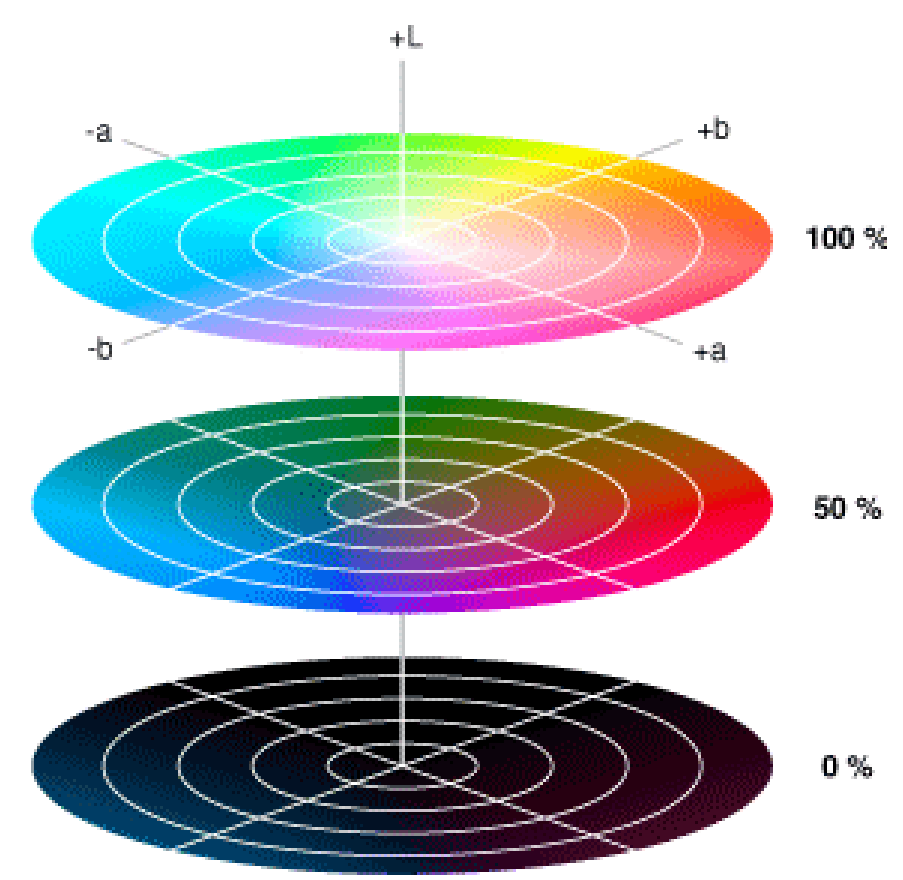

Figura V- 1: Espacio cromático

Se extrajeron muestras a los 0, 2, 4 y 6 meses de almacenamiento congelado, se las acondicionó a temperatura ambiente, y se efectuó la medida de color sobre la cara externa de las mismas por sextuplicado.

El color fue descripto a través de la luminosidad $L^{*}$ y la cromaticidad por los parámetros $\mathrm{a}^{*} \mathrm{y} \mathrm{b}^{*}$. El parámetro $\mathrm{L}^{*}$ varía desde 100 para un blanco perfecto a 0 para el negro, $a^{*}$ representa rojo cuando es positivo, y verde cuando es negativo, y $b^{*}$ representa amarillo cuando es positivo y azul cuando es negativo (Figura V-1).

\section{V.2.8. Diseño experimental y análisis estadístico de los resultados}

Se consideró un diseño con dos factores: tipo de antioxidante y tiempo de almacenamiento congelado. Las determinaciones de TBARS y color se realizaron 
cada 2 meses hasta alcanzar los 6 meses de almacenamiento congelado. El análisis de los resultados se efectuó según lo explicado en III.2.7.

\section{V.3. RESULTADOS Y DISCUSIÓN}

V.3.1. Rendimiento

Con respecto al rendimiento de la obtención de desmenuzado a partir de pescado entero, se observó que los ejemplares capturados en el mes de julio presentaron un rendimiento de $33.02 \pm 0.96 \%$ mientras que en diciembre fue de $26.27 \pm 2.41 \%$. Estas diferencias significativas en los rendimientos de los distintos periodos, puede deberse a las condiciones fisiológicas de los ejemplares. En julio los ejemplares presentan un alto contenido de grasa en el músculo, lo que se refleja en un Índice Somático (IS) mayor con respecto a los valores de IS en diciembre, cuando la saraca se encuentra finalizando el periodo de desove.

Rodríguez Guerrero (2007) observó que el rendimiento en caballa (Scomber Scombrus) es de $30 \%$ y este valor puede variar dependiendo del tamaño de los ejemplares y de la época.

\section{V.3.2. Oxidación lipídica}

En el desmenuzado de julio (Figura V-2) se observó, una efectividad similar desde el inicio del almacenamiento hasta alcanzar los 2 meses de almacenamiento para los desmenuzados con el BHTQ y el extracto de semillas de uva. Las muestras con BHTQ y uva presentaron valores iniciales de TBARS para los antioxidantes de $0.42 \pm 0.06 \mathrm{mg} \mathrm{MDA} / \mathrm{kg}$ y $0.42 \pm 0.09 \mathrm{mg} \mathrm{MDA} / \mathrm{kg}$ respectivamente. Continuando el almacenamiento, el antioxidante BHTQ mantuvo su efectividad con valores de TBARS por debajo de $1 \mathrm{mg} \mathrm{MDA} / \mathrm{kg}$, mientras que el extracto de uva, si bien fue aumentando, el número de TBARS durante el almacenamiento también se mantuvo menor a $2 \mathrm{mg}$ MDA $/ \mathrm{kg}$ de desmenuzado, considerado como límite de aceptabilidad sensorial en cuanto a la oxidación de lípidos (Dalgaard, Gram y Huss, 1996; Chow, 2000; Georgantelis y col., 2007).

La mezcla de tocoferoles presentó un valor inicial de TBARS de $2.39 \pm 0.05 \mathrm{mg}$ $\mathrm{MDA} / \mathrm{kg}$, similar a las muestras control, y a diferencia del comportamiento de los otros antioxidantes mostró un descenso en los TBARS al avanzar el tiempo de almacenamiento. En el control se observó una oxidación considerable desde el comienzo del almacenamiento $(2.00 \pm 0.22 \mathrm{mg} \mathrm{MDA} / \mathrm{kg})$, la que fue aumentando significativamente a lo largo del tiempo, alcanzando el valor máximo a los 6 meses de 
almacenamiento. También en las muestras con extracto de semillas de uva o BHTQ, los valores de TBARS aumentaron durante el almacenamiento.

El orden de efectividad debido al antioxidante independiente del factor tiempo de almacenamiento para las muestras de julio fue BHTQ $(0.69 \pm 0.30 \mathrm{mg} \mathrm{MDA} / \mathrm{kg})>$ extracto de UVA $(1.26 \pm 0.81 \mathrm{mg} \mathrm{MDA} / \mathrm{kg}$ de alimento) $>$ mezcla de tocoferoles 70 $(1.62 \pm 0.63 \mathrm{mg} \mathrm{MDA} / \mathrm{kg})>$ control $(3.14 \pm 0.86 \mathrm{mg} \mathrm{MDA} / \mathrm{kg}$ de alimento)

Con respecto al desmenuzado de diciembre, las muestras presentaron valores mayores de TBARS (Figura V - 3), el contenido de lípidos de esos ejemplares era menor que en julio, $3 \%$ vs. $20 \%$, respectivamente, por lo que si lo expresamos en base lipídica la cantidad de malonaldehído formada en diciembre es todavía más importante respecto a julio, estimamos que podría deberse a las altas temperaturas alcanzadas en diciembre ya que, si bien la temperatura se mantuvo controlada una vez que los ejemplares llegaron al INIDEP, pueden haber sido mayores a bordo del pesquero y durante el transporte. El control presentó valores elevados desde el inicio de la experiencia ( $3 \mathrm{mg} \mathrm{MDA} / \mathrm{kg}$ ) y fue aumentando significativamente a lo largo del almacenamiento a $-25^{\circ} \mathrm{C}$. La efectividad de los antioxidantes en relación al tiempo de almacenamiento fue: mezcla de tocoferoles 70 (1.68 $\pm 0.68 \mathrm{mg} \mathrm{MDA} / \mathrm{kg})>\mathrm{BHTQ}(2.06$ $\pm 1.74 \mathrm{mg} \mathrm{MDA} / \mathrm{kg})>$ extracto de UVA $(2.3 \pm 1.64 \mathrm{mg} \mathrm{MDA} / \mathrm{kg})>$ control $(4.30 \pm 1.74$ $\mathrm{mg} \mathrm{MDA} / \mathrm{kg}$ ). Si bien se observó que el antioxidante más efectivo para el desmenuzado de diciembre fue la mezcla de tocoferoles $70 \%$, no logró mantener los TBARS por debajo de $2 \mathrm{mg} \mathrm{MDA} / \mathrm{kg}$, luego de cuatro mes de almacenamiento congelado. EI BHTQ y el extracto de semillas de uva tampoco mantuvieron los valores de TBARS por debajo de $2 \mathrm{mg}$ MDA/kg, a partir del cuarto mes de almacenamiento. En el caso de la muestra control se observó que los valores iniciales de TBARS fueron de $3.11 \pm 0.20 \mathrm{mg} \mathrm{MDA} / \mathrm{kg}$.

Evaluando la efectividad de los antioxidantes antes de alcanzar los 4 meses de almacenamiento donde todas las muestras con antioxidantes se encontraban por debajo del límite de aceptabilidad sensorial observamos que la media de oxidación no presentó diferencias significativas entre el antioxidante sintético $(0.82 \pm 0.30 \mathrm{mg}$ $\mathrm{MDA} / \mathrm{kg}$ ) y los antioxidantes naturales (tocoferol $1.07 \pm 0.25 \mathrm{mg} \mathrm{MDA} / \mathrm{kg}$ y extracto de uva $1.12 \pm 0.72 \mathrm{mg} \mathrm{MDA} / \mathrm{kg}$ ).

El comportamiento creciente de TBARS para las muestras de pescado también fue observado por otros autores. Sánchez-Alonso y col. (2008) observó este aumento en muestras de desmenuzado de caballa (Trachurus trachurus) con $5.5 \%$ de lípidos y adicionadas con antioxidante obtenido de pulpa de uva blanca al 2 y $4 \%$ durante el almacenamiento congelado. Pazos y col. (2010) observaron el comportamiento en 
muestras de desmenuzado y filetes de caballa almacenadas con diferentes extractos antioxidantes (pino, nuez, uva) observando que la mayor efectividad estaba dada por el extracto de uva con mayor número de monómeros de catequinas. Los polifenoles menos polimerizados presentaron mayor actividad como antioxidantes (Plumb y col., 1998; Touriño y col., 2005).

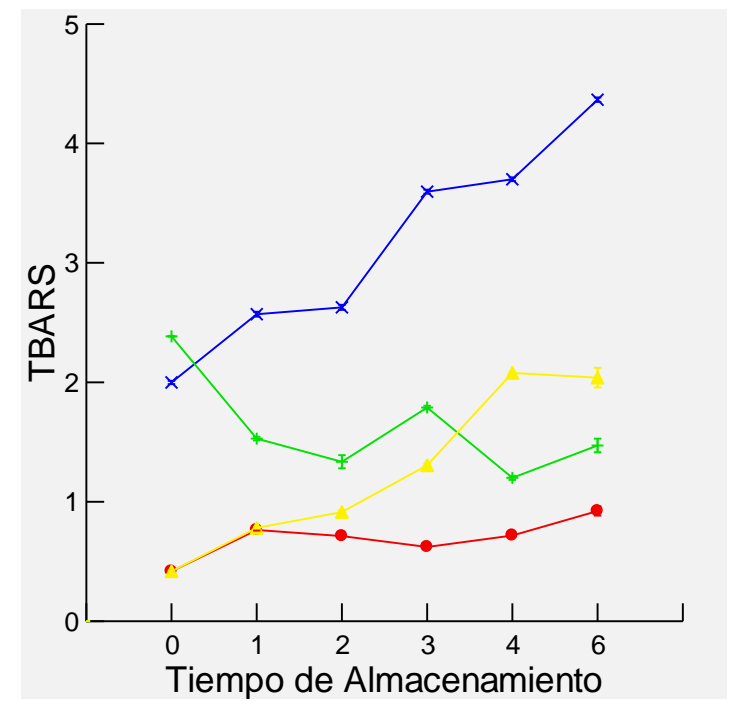

Figura V - 2: Sustancias Reactivas del TBA (TBARS) de desmenuzado de julio almacenado congelado a $-25^{\circ} \mathrm{C}$ durante 6 meses. Las barras expresan el error standard de la media.

- BHTQ $\times$ Control + Tocoferol $\triangle$ Extracto Uva

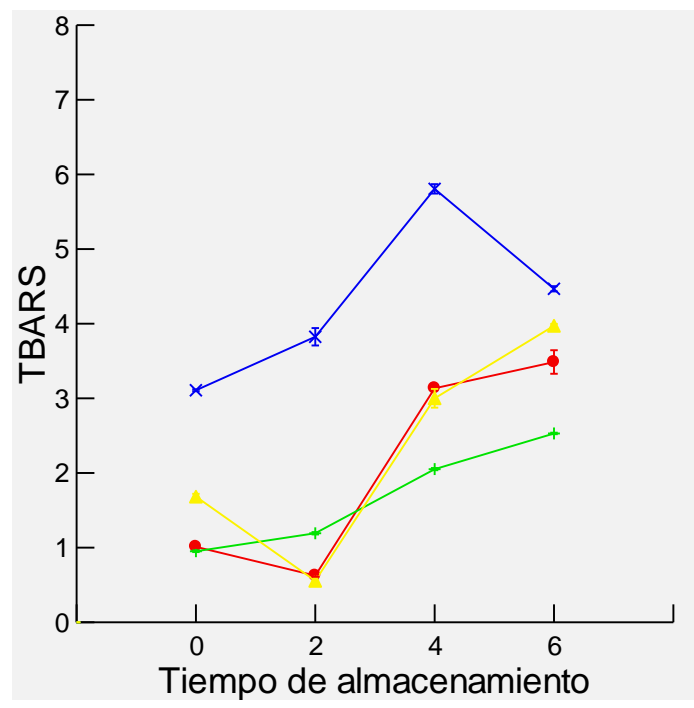

Figura V - 3: Sustancias Reactivas del TBA (TBARS) de desmenuzado de diciembre almacenado congelado a $-25^{\circ} \mathrm{C}$ durante 6 meses. Las barras expresan el error standard de la media.

- BHTQ $\times$ Control + Tocoferol $\triangle$ Extracto Uva 
Los extractos de semilla de uva comerciales son una buena fuente de proantocianinas de baja a media polimerización (2.4 unidades monoméricas) y muestran una buena habilidad para donar electrones, quelar iones férricos y estabilizar antioxidantes (Pazos y col., 2010). El efecto antioxidante del extracto de uva en los desmenuzados de saraca, se debe al elevado contenido de polifenoles presentes en dicho extracto, la dosis utilizada contenía $100 \mathrm{mg}$ de catequinas, compuesto con gran actividad como antioxidante ya que su efecto se basa en que prolonga el periodo de inducción del proceso de oxidación (Pazos y col., 2010).

\section{V.3.3. Color}

Se evaluó el color superficial de los desmenuzados durante su almacenamiento congelado con el fin de evaluar el cambio de coloración en relación al proceso de oxidación de los lípidos. Los parámetros medidos fueron: luminosidad L, a* y b*.

Con respecto al desmenuzado de julio (Figura V-4) no se observaron diferencias significativas en la luminosidad (L) al inicio del almacenamiento, entre los diferentes antioxidantes ensayados. Al avanzar el tiempo de almacenamiento, se observó un aumento de $L$ en los desmenuzados con antioxidantes de uva, control y BHTQ alcanzando valores de luminosidad de 64-65 mientras que la mezcla de tocoferoles no presentó cambios.

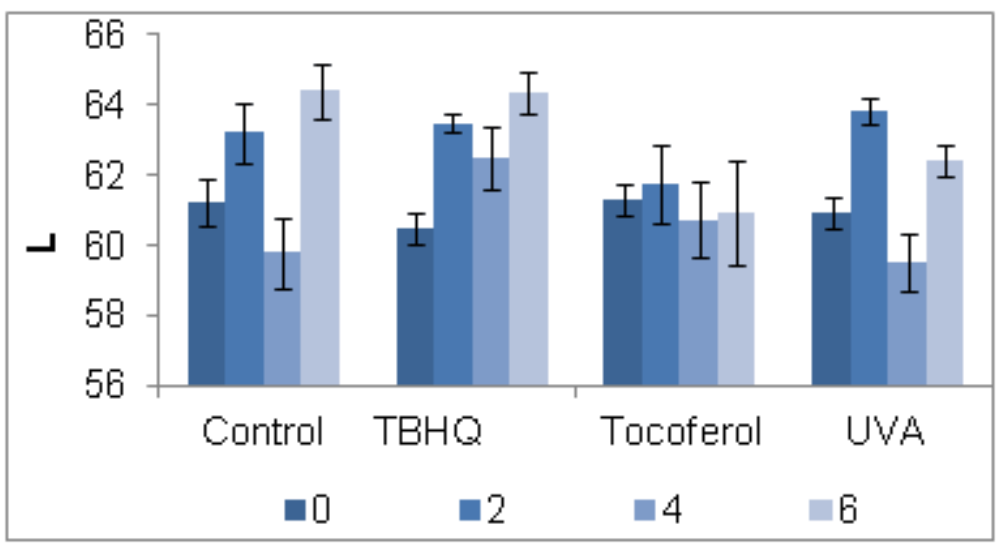

Figura V- 4: Cambios en los parámetros $L^{*}$ en desmenuzado de julio con la incorporación de distintos antioxidantes almacenados a $-25^{\circ} \mathrm{C}$ durante 6 meses. Las barras expresan el error standard de la media.

En la Figura $V-5$ se presentan los valores de los parámetros $a^{*}$ y $b^{*}$ de los desmenuzado de julio con los diferentes antioxidantes. El parámetro a* presentó diferencias significativas entre las distintas muestras siendo para control $(4.00 \pm 1.41)$ $<\operatorname{BHTQ}(4.46 \pm 0.97)<$ tocoferol $(5.04 \pm 1.05)<$ extracto de uva $(5.65 \pm 1.01)$. Al inicio 
del almacenamiento, se observó una mayor coloración anaranjada para las muestras con extracto de uva $\left(a^{*}=7.47 \pm 0.26\right)$ sin presentar diferencias con las formulaciones con tocoferoles $\left(a^{*}=6.45 \pm 0.46\right)$, mientras que los tocoferoles tampoco difirieron significativamente, al inicio del almacenamiento, de las muestras con BHTQ $\left(a^{*}=5.91\right.$ $\pm 0.58)$ o de las formulaciones control $\left(a^{*}=5.50 \pm 1.08\right)$. A su vez se observó que todos los antioxidantes evaluados presentaron una reducción significativa de este parámetro durante el primer mes de almacenamiento y luego se mantuvo sin variaciones durante el resto del almacenamiento congelado. Este mismo comportamiento lo observó Sánchez-Alonso y col. (2011) en muestras de desmenuzado de caballa adicionadas con ácido caféico y fibra dietaría de trigo como antioxidante.

El parámetro $b^{*}$ (Figura $V-5$ ) también arrojó diferencias significativas entre los desmenuzados de julio al comienzo del almacenamiento, reiterándose un mayor valor para la muestra con extracto de semillas de uva. Tanto los desmenuzados con antioxidantes como el control presentaron un comportamiento creciente en el valor $b^{*}$ a lo largo del almacenamiento, lo que se asocia con la coloración amarilla típica de los productos de oxidación (Sánchez-Alonso y Borderías, 2008).

Sánchez-Alonso y col. (2011) observó, en muestras de desmenuzado de caballa con $6 \%$ de lípidos en músculo, adicionadas con antioxidante ácido caféico y fibra de trigo, el mismo comportamiento en el parámetro de luminosidad; L* presentaba pequeñas diferencias al inicio del almacenamiento, principalmente debido a las características de color que puede aportar el antioxidante incorporado. También observaron en las muestras con antioxidante que la reducción del parámetro $a^{*}$ era menor que en la muestra control, esto se correlaciona con el efecto inhibidor de cada antioxidantes, a la reducción de la oxidación de la hemoglobina y al menor número de productos de peroxidación de los lípidos. Algunos autores proponen la reducción del parámetro $\mathrm{a}^{*}$ en especies pelágicas como una medida indirecta para evaluar la oxidación de la hemoglobina presente en músculo de pescado como así también de los lípidos oxidados (Undeland, Ekstrand, y Lingnert, 1998). Esto es especialmente importante para especies como jurel cuyo músculo contiene grandes cantidades de hemoglobina, un activador conocido de la oxidación de lípidos (Richards y Hultin, 2000; Richards, Modral y Li, 2002; Undeland, Hultin y Richards, 2002). 


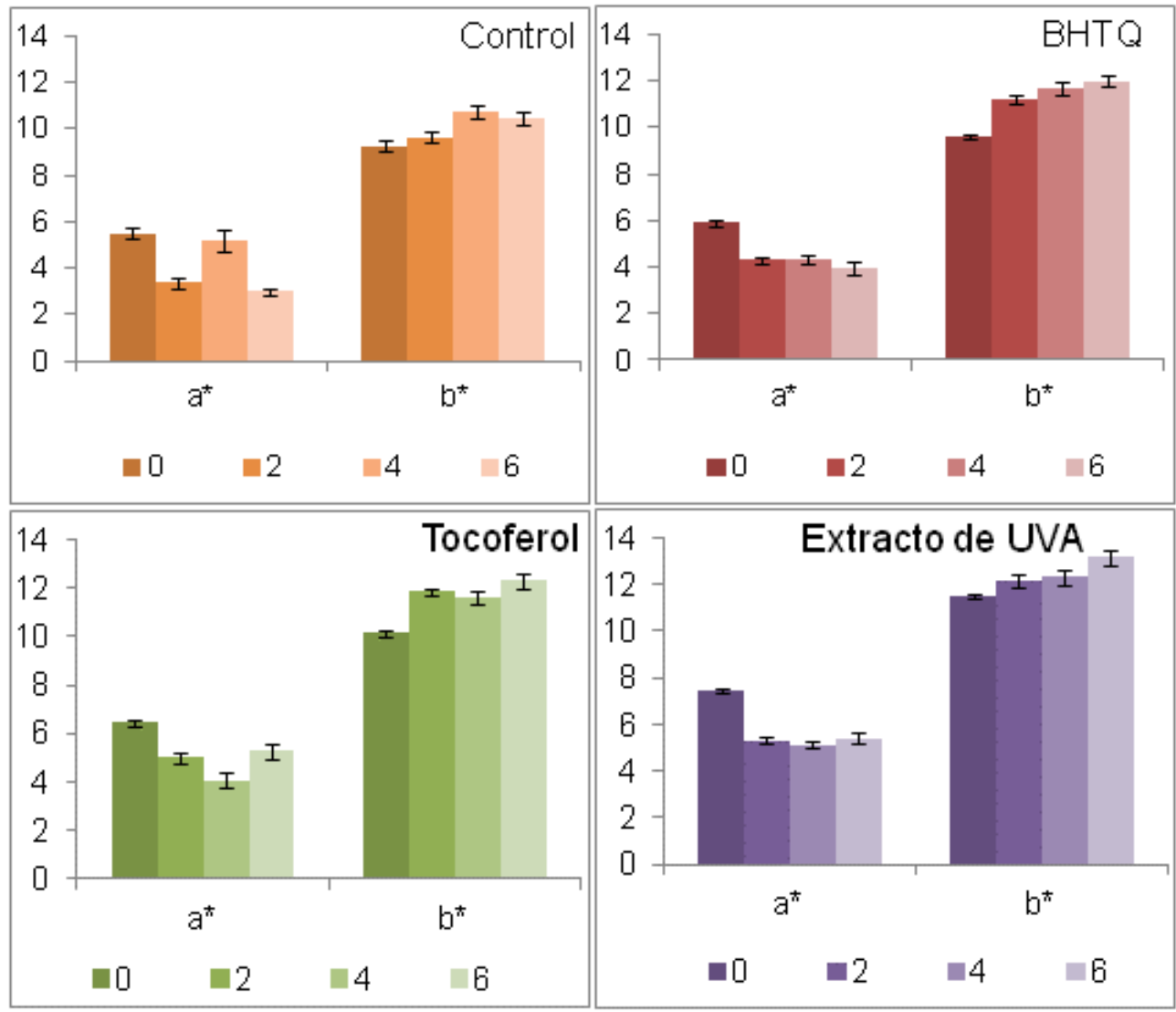

Figura $\mathrm{V}$ - 5: Cambios en los parámetros $\mathrm{a}^{*} \mathrm{y} \mathrm{b}^{*}$ en desmenuzado de julio con la incorporación de distintos antioxidantes almacenados a $-25^{\circ} \mathrm{C}$ durante 6 meses. Las barras expresan el error standard de la media.

En el análisis de color de los desmenuzados de diciembre, tampoco se observaron diferencias significativas en el parámetro $L^{*}$ entre los desmenuzados formulados con distintos antioxidantes (Figura $V-6$ ). El valor inicial fue: $L^{*}=54.39 \pm$ 1.17 para la formulación con tocoferoles; $54.13 \pm 0.40$ para el control; $52.90 \pm 2.29$ para la formulación conteniendo BHTQ y $52.38 \pm 1.76$ para el extracto de uva; sin presentar cambios significativos a lo largo del tiempo de almacenamiento congelado.

El parámetro $a^{*}$ mostró diferencias significativas entre los distintos antioxidantes desde el inicio del almacenamiento, siendo nuevamente el extracto de uva el de mayor coloración anaranjada, seguido por el control y en menor medida las muestras con BHTQ y mezcla de tocoferoles.

Al igual que en el trabajo de Sánchez-Alonso y col. (2008) en desmenuzado de caballa con antioxidantes de uva, en el presente trabajo, también se observó que el parámetro $\mathrm{a}^{\star}$ no varió durante el tiempo de almacenamiento de los desmenuzados de diciembre conteniendo antioxidantes, mientras que el valor del control se redujo significativamente. 


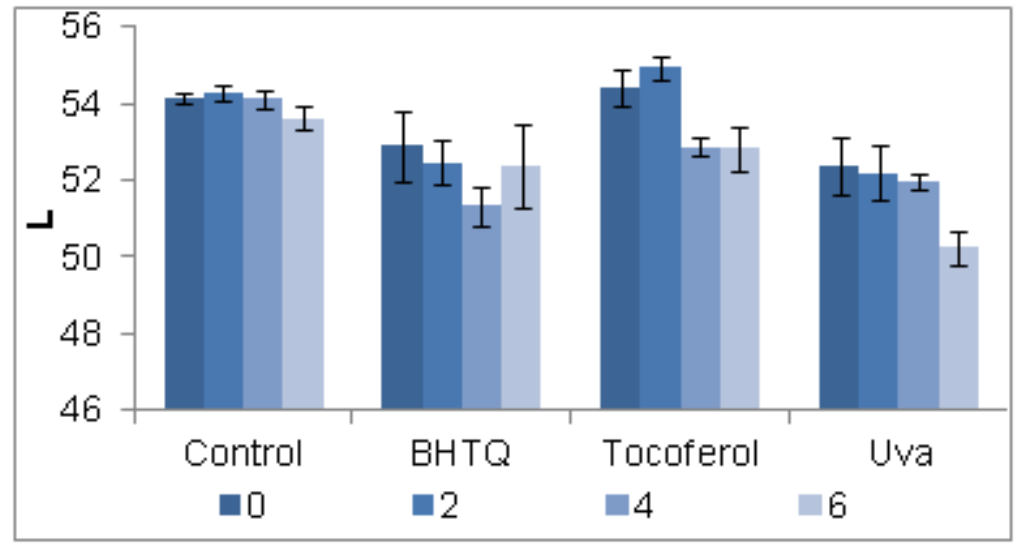

Figura V- 6: Cambios en los parámetros $L^{*}$ en desmenuzado de diciembre con la incorporación de distintos antioxidantes almacenados a $-25^{\circ} \mathrm{C}$ durante 6 meses. Las barras expresan el error standard de la media.

La reducción del valor a* (Figura $V-7$ ) está relacionado con una reducción en el color rojizo del material fresco, la aparición de coloración verdosa y tal vez con el desarrollo de compuestos de la oxidación de lípidos en la muestra (Burgaard y Jørgensen, 2010).

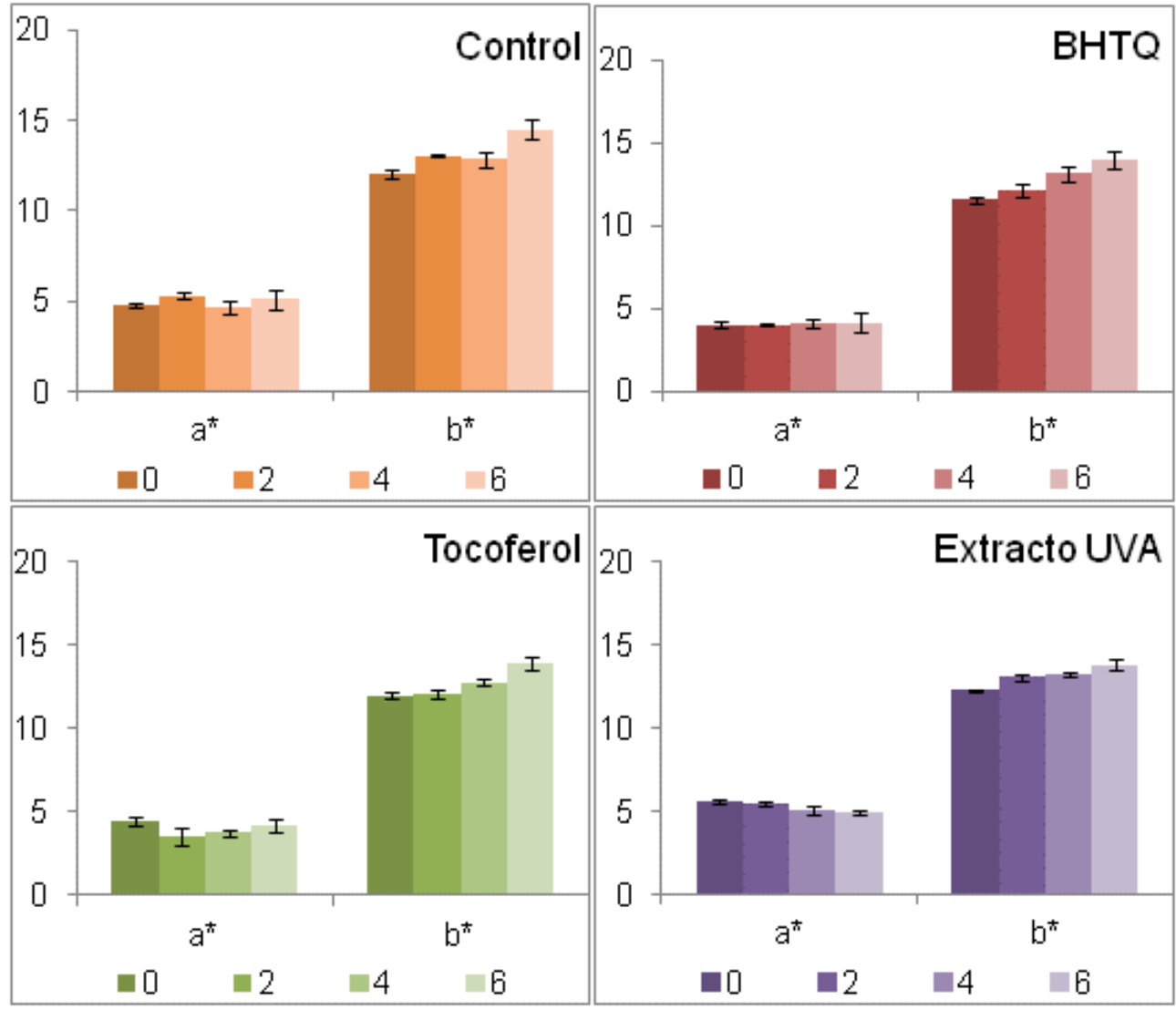

Figura V - 7 Cambios en los parámetros $a^{*}$ y $b^{\star}$ en desmenuzado de diciembre con la incorporación de distintos antioxidantes almacenados a $-25^{\circ} \mathrm{C}$ durante 6 meses. Las barras expresan el error standard de la media. 
El parámetro $b^{*}$ no presentó diferencias significativas entre los desmenuzados al comienzo del almacenamiento $b^{*}=12.9 \pm 0.11$. Los cuatro desmenuzados presentaron un comportamiento creciente en el valor $\mathrm{b}^{*}$ a lo largo del almacenamiento, lo que se asocia con la coloración amarilla, la pérdida natural del color rosado del material utilizado, la oxigenación de las hemoglobinas, la aparición de colores pardos debidos a la oxidación de pigmentos y de los productos de la oxidación de lípidos. Estos cambios están asociados también con el oscurecimiento del músculo rojo del pescado, resultado de la formación de metamioglobina (Chaijan y col., 2005).

\section{V.4. CONCLUSIONES}

El antioxidante sintético (BHTQ) fue el de mejor acción antioxidante para el desmenuzado de julio. Sin embargo, es importante destacar que el extracto de semillas de uva le siguió en efectividad presentando un buen comportamiento, manteniendo los valores de TBARS por debajo del límite máximo durante todo el período de almacenamiento analizado para el desmenuzado de julio. Con respecto al desmenuzado de diciembre, los valores de TBARS fueron elevados desde el inicio de la experiencia, manteniéndose por debajo de $2 \mathrm{mg} \mathrm{MDA} / \mathrm{kg}$ de músculo sólo hasta el cuarto mes de almacenamiento.

Los elevados valores iniciales de TBARS correspondientes al mes de diciembre pueden explicarse por las altas temperaturas del verano, las que probablemente favorecieron la aceleración del desarrollo de la etapa de iniciación del proceso de oxidación en el pescado. Para evitar este rápido desarrollo de la rancidez en los desmenuzados realizados durante el periodo de verano, se deberían tomar mayores cuidados por parte de la flota costera y mejorar las condiciones de almacenamiento desde el momento de la captura. Controlando la temperatura a bordo, los antioxidantes naturales ensayados en este periodo, deberían dar resultados tan buenos como en el desmenuzado de julio, donde los valores de TBARS se mantuvieron por debajo de los $2 \mathrm{mg} / 100 \mathrm{~g}$ músculo pese a que el contenido de lípidos era casi 10 veces mayor.

La adición de antioxidantes naturales, como los ensayados en este trabajo se pueden considerar como buenos inhibidores del desarrollo de la oxidación en desmenuzado de músculo saraca durante el almacenamiento congelado a $-25^{\circ} \mathrm{C}$ durante al menos 6 meses. 


\section{CAPITULO VI \\ ALMACENAMIENTO CONGELADO DE DESMENUZADO DE MÚSCULO DE SARACA: CALIDAD HIGIENICO-SANITARIA}

\section{VI.1. Calidad del pescado.}

El consumo de pescado creció significativamente en los últimos años, en gran parte debido a sus beneficios nutricionales que aporta a la dieta: es una fuente de proteínas de alto valor biológico, de vitaminas como la A, D y E, de ácidos grasos poliinsaturados de la familia $n-3$, por todo esto el consumidor lo considera un alimento saludable. Si bien el pescado es un alimento muy saludable, no debemos olvidar que es un producto muy perecedero y como tal se debe acondicionar adecuadamente y procesar en forma rápida. El pescado mal acondicionado y mal procesado, desde el momento de la captura y hasta su consumo, puede presentar un riesgo para la salud del consumidor. El desmenuzado de pescado es un producto muy versátil para su utilización, pero microbiológica y químicamente es inestable. Por lo cual es necesario el control de la calidad de la materia prima y cuidar las etapas de obtención, y su posterior utilización. El deterioro del pescado se debe principalmente a dos factores, enzimas endógenas y bacterianas (Ellis y Silva, 1997; Huss, 1998). La singularidad de las enzimas, tejido muscular y la flora bacteriana está asociada a cada especie. Los metabolitos de la acción bacteriana y la degradación enzimática, se pueden utilizar como indicadores de la frescura del pescado, según si son producidos en el músculo en las primeras etapas del deterioro (autolítico) o es producto de las bacterias en las etapas posteriores (Ellis y Silva, 1997).

Por lo general, como ya se comentó en el Capítulo 1, el pescado desmenuzado permite obtener mayores rendimientos de la carne comestible. En las especies comerciales se suele recuperar la carne procedente de los restos que se generan durante el proceso de filetado. También se puede utilizar para su obtención el pescado entero de las especies con valor o aprovechar aquellas de descarte. Cualquiera sea el caso, la materia prima que se utilice debe provenir de pescado fresco refrigerado en forma adecuada con hielo y de buena calidad higiénico-sanitaria. Para determinar el grado de frescura en pescado, particularmente para especies magras, se utiliza un método de determinación del nitrógeno básico volátil total (NBVT).

Según la especie de la que provenga el desmenuzado de pescado, diferente será la intensidad de los problemas o peligros que presente durante su almacenamiento y para el consumidor. En el caso particular de la carne de especies 
grasas como es la saraca, el desmenuzado presenta una gran susceptibilidad a la oxidación de los lípidos poli-insaturados que se suma a la acción de las enzimas proteolíticas que actúan sobre el músculo durante su almacenamiento.

Los compuestos que se generan durante el proceso de deterioro, pueden presentar problemas toxicológicos procedentes de la contaminación microbiana. La formación de histamina es particularmente el producto de deterioro microbiano de la histidina, presente en especies como escómbridos, clupeidos, scaridos, mugilidos. También se puede sumar una alta concentración de plaguicidas y otras toxinas, como los PCB, en grandes peces procedentes de aguas contaminadas (Grantham, 1981). Existen otros riesgos potenciales que pueden formar parte del desmenuzado y son inherentes al pescado utilizado. Estos peligros son tanto biológicos, debido a la presencia de parásitos en músculo, como físicos, debido a las espinas que puedan pasar durante el proceso de desmenuzado.

\section{VI.1.1. Nitrógeno básico volátil total}

EI NBVT es uno de los índices más difundido para la determinación de frescura de los productos pesqueros. Independientemente de las consideraciones técnicas que se puedan hacer sobre la relevancia de este índice como indicador de la frescura del pescado, es indudable que el mismo se ha afianzado en todas las transacciones comerciales de productos pesqueros en todo el mundo. En el Capítulo VI - Alimentos Cárneos y Afines del Código Alimentario Argentino, el artículo 276 - (Dec 748, 18.3.77) establece como valor máximo de NBVT, para todas las especies; especifica que no es apto para el consumo humano los productos pesqueros "Que contengan en $100 \mathrm{~g}$ de parte comestible una cantidad superior a $30 \mathrm{mg}$ de nitrógeno básico volátil".

EI NBVT determina compuestos nitrogenados de carácter volátil que se liberan como consecuencia del proceso de degradación post-mortem, por acción autolítica y acción microbiana. Desde la muerte hasta la resolución del rigor mortis, los procesos autolíticos van a favorecer la formación de compuestos nitrogenados (compuestos intermediarios de la degradación del ATP, péptidos y aminoácidos libres). En esta etapa el desarrollo de los compuestos es lento, mientras que se intensifica cuando los microorganismos entran en juego una vez que se resuelve el rigor mortis. Los microorganismos producen enzimas que degradan compuestos nitrogenados de mayor peso molecular (proteínas, óxido de trimetilamina, urea) aumentando el número de los compuestos de nitrógeno soluble (péptidos, aminoácidos libres, trimetilamina amoníaco). Los metabolitos de deterioro producidos en el pescado por las reacciones 
autolíticas y por los microorganismos, son cuantificados como el nitrógeno básico volátil total.

Algunos de los compuestos que se cuantifican con esta técnica son:

- Trimetilamina (producida por deterior bacteriano)

- Dimetilamina (producida por enzimas autolíticas durante el almacenamiento en congelación).

- Amoníaco (producido por desaminación de aminoácidos y catabolitos de nucleótidos).

- Otros compuestos volátiles nitrogenados asociados con el deterioro de los productos pesqueros.

Si bien es una técnica simple presenta ciertas limitaciones. Refleja la pérdida del grado de frescura del pescado en estadios relativamente avanzados de deterioro, fundamentalmente cuando se inicia la etapa de deterioro por acción bacteriana. Sin embargo, el valor de NBVT es importante para determinar hasta cuándo un pescado es apto para el consumo humano. El rápido aumento del NBVT depende de la acción de las enzimas que generan los microorganismos, por lo cual un lavado adecuado disminuirá la carga bacteriana y si se continúa con un adecuado almacenamiento refrigerado, se reducirá la proliferación de los microorganismos causantes del deterioro.

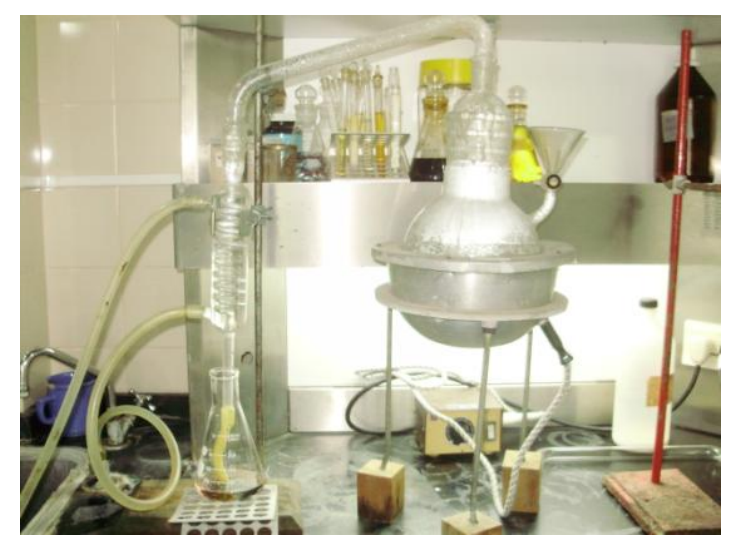

Figura VI - 1: Equipo de Antonacopoulos.

El ente de control de la calidad higiénico-sanitaria de productos de la pesca en Argentina es el Servicio Nacional de Sanidad y Calidad Agroalimentaria Argentina (SENASA) que se basa en el Digesto Normativo del Servicio Nacional de Sanidad Animal (Decreto 4238 - Capítulo XXIII,) donde se establece dentro de las determinaciones químicas del pescado fresco, el NBVT se determina por el método de Antonacopoulos (Figura VI - 1). También se aclara en el Decreto 4238 que para 
pescados uricotélicos (cazones, tiburones, etc.) que por su alto contenido de urea en músculo el valor inicial es mayor de 30 mg NBVT/100 g de músculo.

VI.1.2. Microorganismos en el desmenuzado de pescado.

El músculo de un pez saludable o de un pescado recién capturado es estéril, debido a que el sistema inmunológico del pez previene el crecimiento de bacterias en el músculo (Huss, 1988). Pasado un tiempo de la muerte, el sistema inmunológico del pez colapsa y las bacterias proliferan libremente. En la superficie de la piel del pescado, las bacterias colonizan en una amplia extensión en la base de las escamas. Durante el almacenamiento en hielo sólo un número limitado de bacterias de la flora inicial invade el músculo penetrando entre las fibras musculares (Murray y Shewan, 1979), contribuyendo al deterioro. La flora microbiana inicial en el desmenuzado de pescado, depende en gran medida del grado de contaminación inicial de la materia prima, ya sea de los recortes o restos de fileteado, como del pescado entero, y del almacenamiento adecuado. Dada las características del proceso de separación se incrementa el recuento total de microorganismo en el desmenuzado, lo que puede acelerar el deterioro (Grantham, 1981; Dalgaard, 1993).

La flora inicial del pescado depende de varios factores como:

- Ambiente de la zona de captura

- Estación del año

- Método de pesca

- Manipulación y procesado

Los microorganismos se encuentran en todas las superficies externas (piel y branquias) y en los intestinos de los peces vivos y recién capturados. El número total de microorganismos varía enormemente. Liston (1980) estableció como rango normal $10^{2}-10^{7}$ UFC $/ \mathrm{cm}^{2}$ en la superficie de la piel y Shewan (1962) $10^{3}$ y $10^{9} \mathrm{UFC} / \mathrm{g}$ en branquias e intestinos. Las bacterias en peces de aguas templadas son clasificadas en psicrótrofas y psicrófilas, de acuerdo al rango de su temperatura de crecimiento. Las psicrótrofas son bacterias capaces de crecer a $0^{\circ} \mathrm{C}$ pero su óptimo es alrededor de los $25^{\circ} \mathrm{C}$. Las psicrófilas son bacterias con una temperatura máxima de crecimiento alrededor de los $20^{\circ} \mathrm{C}$ y su óptimo a $15^{\circ} \mathrm{C}$, creciendo también a $0^{\circ} \mathrm{C}$ (Morita, 1975). En las aguas cálidas pueden aislarse un mayor número de mesófilos (temperatura óptima entre 30 y $40^{\circ} \mathrm{C}$ ) (Huss, 1988).

Cuando se almacena pescado en refrigeración su deterioro es resultado, principalmente, de las bacterias psicrótrofas que crecen fácilmente y se multiplican a bajas temperaturas (Shewan, 1977; Surendran y Gopakumar, 1981). La microflora 
inicial del pescado es muy variada, aunque en aguas templadas está dominada por bacterias psicrófilas Gram negativas, pertenecientes a los géneros Pseudomonas, Moraxella, Acinetobacter, Shewanella y Flavobacterium. También se pueden encontrar organismos Gram positivos como Bacillus, Micrococcus, Clostridium y Lactobacillus en distintas proporciones (Shewan, 1977). En aguas marinas, las más abundantes son aquellas bacterias dependientes del cloruro de sodio para su crecimiento; los géneros más importantes son Alteromonas, Vibrio, Photobacterium y Shewanella (Gram, Wedell-Neergaard y Huss, 1990; Spanggaard y col., 1993; DiChristina y DeLong, 1994). Los microorganismos del deterioro en pescado son los géneros Pseudomonas, Shewanella, Moraxella y Acinetobacter (Huss, 1988).

El recuento total de bacterias en placa es un método útil para obtener una idea del grado de frescura o pronta alteración de los alimentos, dependiendo de la cantidad de bacterias presentes. Los alimentos deben ser considerados como inadecuados para el consumo cuando contienen un gran número de microorganismos alteradores, ya sea que superen el límite máximo establecido o se detecte la presencia de microorganismos patógenos. En pescado fresco el límite máximo de microorganismos recomendado para consumo es $10^{7} \mathrm{ufc} / \mathrm{g}$ (ICMSF, 1986). La presencia de microorganismos aerobios mesófilos en los alimentos puede ser relacionada directamente con contaminación externa debida a la manipulación, el estado de frescura o de descomposición del producto, o bien, con la temperatura de conservación del producto (Venegas y col., 1990).

\section{VI.1.3. Histamina en desmenuzado de pescado}

La histamina es un compuesto que se produce en algunas familias de pescados por descarboxilación de la histidina y causa síntomas alérgicos inmediatamente después de consumirlos. Se la conoce con el nombre escombrotóxina, y produce una intoxicación causada por la ingestión de especies como el atún, el bonito y caballa (especies pertenecientes a la Familia Scombridae, de ahí su nombre) o bien de otras especies grasas más pequeñas como arenques, sardinas y anchoas (Huss, 1988). La formación de esta amina biógena se produce como resultado de una conservación y/o manipulación inadecuada. Al almacenar estas especies a temperaturas mayores $8^{\circ} \mathrm{C}$ se desarrollan algunas bacterias capaces de descarboxilar a la histidina y formar histamina. La histamina es resistente al calor, por lo cual no se eliminará en tratamientos posteriores, tales como la elaboración de conservas o el ahumado (Huss, 1988). Las especies peligrosas para la formación de esta toxina, como son los escombridos y los cupleidos, tienen como característica una alta concentración de 
histidina en músculo, que como se explicó con anterioridad es descarboxilada cuando el pescado se expone a altas temperaturas y favorece el desarrollo de los microorganismos del género Enterobacteriaceae como Proteus morganii, Klebsiella y Hafnia spp. generadores de enzima descarboxilasa. Estos microorganismos se desarrollan lentamente hasta temperaturas de $8^{\circ} \mathrm{C}$, pero a partir de $15^{\circ} \mathrm{C}$ se desarrollan rápidamente y forman grandes cantidades de histamina y el pescado puede ser tóxico aún cuando microbiológicamente sea apto para su consumo. Algunos autores recomiendan el uso de temperaturas de refrigeración inferiores a $5^{\circ} \mathrm{C}$, para inhibir la formación de histamina (Cheftel y Cheftel, 1976; De Sousa y Byan, 1991). Si el pescado es almacenado en frío desde su captura, los niveles normales de histamina no superan los 3 a $4 \mathrm{mg} / 100 \mathrm{~g}$ de pescado. Los brotes por intoxicación con histamina se asocian a concentraciones superiores a $20 \mathrm{mg} / 100 \mathrm{~g}$ de pescado, por lo que internacionalmente se ha sugerido ese valor como límite máximo (Huss, 1988). El Codex Alimentarius en su norma para bloques de filetes de pescado, carne de pescado picada y mezclas de filetes y de carne de pescado picada congelados rápidamente (CODEX STAN 165-1989, Rev. 1-1995) establece que "el producto no deberá contener más de $10 \mathrm{mg} / 100 \mathrm{~g}$ de histamina, tomando como base la media de la unidad de muestra analizada". Esta disposición se aplica únicamente a las especies pertenecientes a las familias Clupeidae, Scombridae, Scombresocidae, Pomatomidae y Coryphaenidae". Mientras que según la normativa de SENASA, decreto 4238 Capítulo XXIII, para histamina en pescado establece: "el valor medio de un conjunto de muestras de un mismo lote, deber ser inferior a los 100 ppm y ninguna muestra podrá tener un valor superior a 200 ppm." En la Tabla VI-1 se presentan las principales especies identificadas como generadoras de histamina.

Tabla VI- 1 Especies más comunes identificadas como riesgosas para la salud por envenenamiento con histamina (Köse, 2010).

\begin{tabular}{|ll|}
\multicolumn{1}{|c|}{$\begin{array}{c}\text { Nombre } \\
\text { Comercial }\end{array}$} \\
Anchoa & $\begin{array}{l}\text { Anchoa spp., Anchoviella spp., Cetengraulis } \\
\text { mysticetus, Engraulis spp., Stolephorus spp. }\end{array}$ \\
\hline Anchoa de banco & Pomatomus saltatrix \\
\hline Bonito & $\begin{array}{l}\text { Cybiosarda elegans, Gymnosarda unicolor, } \\
\text { Orcynopsis unicolor, Sarda spp. }\end{array}$ \\
\hline Arenque & Alosa spp., Alosa pseudoharengus, Etrumeus teres, \\
\hline
\end{tabular}




\begin{tabular}{|ll|}
\hline & $\begin{array}{l}\text { Harengula thrissina, llisha spp., Opisthopterus } \\
\text { tardoore, Pellona ditchela, Clupea spp., } \\
\text { Opisthonema spp. }\end{array}$ \\
\hline Caballa & Gasterochisma melampus, Grammatorcynus spp., \\
& Rastrelliger kanagurta, Scomber scombrus, \\
& Scomber spp., Trachurus spp., Scomberomorus spp. \\
\hline Sardina & Sardina pilchardus, Sardinops spp., Harengula spp., \\
& Sardinella spp. \\
\hline Salmón & Onchorhynchus keta, O. kisutch, O. gorbuscha, O. \\
& nerka \\
\hline Atún & Allothunnus fallai, Auxis spp., Euthynnus spp., \\
& Katsuwonus pelamis, Thunnus tonggol, T. alalunga, \\
& T. albacares, T. atlanticus, T. maccoyii, T. obesus, T. \\
& thynnus.
\end{tabular}

VI.1.4. Espinas en desmenuzado de pescado.

Las espinas son consideradas un riesgo físico en los productos de la pesca. Son una de las principales causas de rechazo por parte del consumidor. Producen una sensación poco agradable en la boca y se suele dudar de los productos pesqueros por el riesgo de sufrir ahogos al ingerirlas. Los alimentos como hamburguesas, se producen con desmenuzado de pescado que se obtiene pasando por una separadora de piel y espinas el pescado descabezado y eviscerado, recortes de filetes, filetes o incluso espinazos del proceso de fileteado. Existen diversos equipos separadores con diferentes tamaños de perforaciones y en algunos casos pueden pasar espinas al desmenuzado. A su vez, depende en gran medida de la cantidad y el tipo de espinas que es una característica propia de cada especie.

La norma del Codex Alimentarius (Codex stan 165-1989, rev. 1-1995) para bloques de filetes de pescado, carne de pescado picada y mezclas de filetes y de carne de pescado picada congelados rápidamente define como defecto la presencia de espinas en bloques de desmenuzado, declarados como producto sin espinas. La norma establece como defectuoso la presencia de más de una espina de $10 \mathrm{~mm} o$ más de longitud o de $1 \mathrm{~mm}$ o más de diámetro por kilogramo de producto; una espina de $5 \mathrm{~mm}$ de longitud o menos no se considera un defecto siempre y cuando su diámetro no supere los $2 \mathrm{~mm}$; la base de una espina (por donde estaba unida a la 
vértebra) no se tomará en cuenta si tiene $2 \mathrm{~mm}$ de ancho o menos o si puede sacarse fácilmente con la uña."

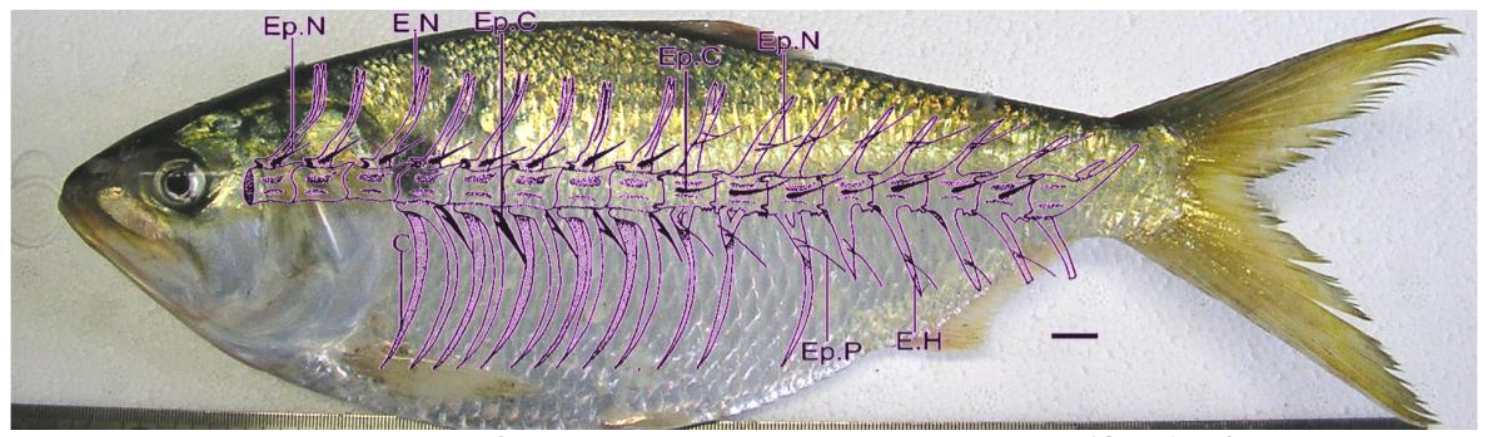

Figura VI- 2: Distribución de espinas de Brevoortia aurea (Spix). C: costilla; E.H: espina hemal; E.N: espina neural; Ep.C: epicentral; Ep.N: epineural; Ep.P: epipleural. Escala: 5 mm (Segura y Díaz de Astarloa, 1994).

Por ello, es importante cuantificar el número y tamaño de espinas en estos productos como factor de calidad y seguridad alimentaría de la materia prima. La cantidad y tamaño de las espinas que pasan al desmenuzado durante el proceso de separación, varía según la especie y el equipamiento que se utilice. En el caso de la saraca, como se explicó en capítulos anteriores, presenta una estructura ósea muy particular, donde la distribución intramuscular de las espinas alcanza a todo el músculo comestible de la Brevoortia aurea (Figura VI - 2).

\section{VI.1.5. Parásitos}

Un parásito es aquel ser vivo que pasa una parte, o la totalidad de su vida, en el interior o exterior de otro ser vivo de diferente especie, al que se denomina hospedador. La presencia de parásitos en el pescado es muy común. La mayoría no son importantes desde el punto de vista sanitario pero representan un problema para la calidad, dado que su presencia es antiestética, causando el rechazo y quejas del comprador-consumidor. En las especies óseas generalmente predominan los parásitos protozoarios. Algunos, presentan actividad proteásica extracelular causando pérdidas en la textura del músculo, otros causan lesiones, quistes redondos de $0.5-1 \mathrm{~cm}$ en músculo de especies como en el salmón del Pacífico (Onchorhynchus spp.). También se distingue otro tipo de parásito los trematodos, éstos son gusanos planos con un ciclo de vida complejo donde el hombre puede ser huésped definitivo y se ubican en el tracto digestivo. El pescado es un huésped intermediario y se transmite al humano a partir del consumo de pescado crudo o poco cocido. La mayoría de los trematodos de 
interés sanitario se encuentran en aguas tropicales, razón por la cual en las especies del Mar Argentino no se encuentran representados.

Otro tipo de parásito que se puede encontrar son los cestodos, la tenia de los peces tiene alcance mundial, pero con distribución localizada. La biología de este grupo involucra dos tipos de huéspedes intermedios: copépodos y pescados. Por último los nematodos, son gusanos redondos, blanquecinos, macroscópicos. Tienen importancia sanitaria debido a que determinadas especies pueden afectar al hombre, infestándolo cuando éste consume pescado crudo o no totalmente cocido. El gusano adulto vive en el intestino, riñones u otros órganos de mamíferos o pájaros que se alimentan de pescado. En el pescado, la larva esta enquistada o libre en la cavidad abdominal o en el músculo lateral del cuerpo. Uno de los nematodos más comunes que parasitan el pescado son los pertenecientes al género Anisakis, un gusano de 1 a $4 \mathrm{~cm}$ de longitud. Su presencia en pescado representa un problema en el mercado debido a las implicancias con la salud del consumidor (Huss, 1988). Los esfuerzos para controlar la presencia de Anisakis en pescado van dirigidos, más que a la detección, a la prevención a través de medidas previas a su comercialización. Las medidas de lucha deberían ser más importantes para los productos pesqueros que se van a comer crudos o sin cocinar como el pescado en escabeche, pescado ligeramente salado, pescado ahumado en frío, ceviche, sashimi o sushi (Incorvaia, 2012 a).

Para inactivar los parásitos patógenos para el humano se recomienda tratar al pescado:

- Térmicamente: $55^{\circ} \mathrm{C}$ durante 1 minuto

- Congelar:

- $-20^{\circ} \mathrm{C}$ su mantenimiento $\times 24$ horas o más

- $-35^{\circ} \mathrm{C}$ su mantenimiento $\times 15$ horas ó más.

- Salar:

$\% \mathrm{NaCl}$ en los tejidos Tiempo máximo de supervivencia de nematodes
4-5
17 semanas
6-7
10-12 semanas
8-9
6 semanas

Algunos productos de la pesca no son inocuos:

- Salados ligeramente (<5-6\% de $\mathrm{NaCl}$ en la fase acuosa).

- Pescado ahumado en frío.

- Caviar ligeramente salado.

- Ceviche y diversos productos tradicionales. 
En la elaboración de estos productos se debe contemplar un período corto de congelación, bien de la materia prima o bien del producto final, como medida de lucha contra los parásitos (Incorvaia, 2012b). En el Reglamento (CE) № 853/2004 del Parlamento Europeo y del Consejo de 29 de abril de 2004 se establecen normas específicas de higiene de los alimentos de origen animal. Se prevé la obligación de congelar los productos de la pesca para consumir crudos, incluso en el comercio al por menor (que abarca a los establecimientos que sirven comida), incluyendo el caso de ahumados, escabeches y salazones.

En el presente Capítulo se estudió la calidad higiénico-sanitaria del desmenuzado de saraca proveniente de ejemplares con dos estadios biológicos (previo al desove y al concluirlo). Se determinó la formación de metabolitos del nitrógeno básico volátil total y la carga microbiana tanto en el desmenuzado fresco, como a lo largo de 6 meses de almacenamiento congelado a $-25^{\circ} \mathrm{C}$. Asimismo se determinó histamina en músculo y recuentos de espinas. Además se analizó la presencia de parásitos en ejemplares enteros frescos.

\section{VI.2. MATERIALES Y MÉTODOS}

VI.2.1. Material utilizado.

Para la obtención de desmenuzado se utilizaron ejemplares de saraca capturados en julio y diciembre 2010. El desmenuzado se obtuvo siguiendo la metodología explicada en IV.2.1., se acondicionó y se congeló siguiendo la metodología explicada en IV.2.2. También se utilizaron saracas enteras y filetes de ejemplares capturados en mayo 2010 para determinar parásitos y espinas en músculo entero. Los desmenuzados fueron utilizados para realizar determinaciones de: NBVT, contenido de histamina, recuentos microbianos al inicio y final del almacenamiento congelado a $-25^{\circ} \mathrm{C}$ y también se utilizaron para analizar el contenido de fragmentos de espinas. La temperatura ambiental durante el procesamiento en planta del pescado osciló entre $5.5^{\circ} \mathrm{C}$ al comienzo del procesamiento y $6.7^{\circ} \mathrm{C}$ al finalizar.

\section{VI.2.2. Determinación de NBVT}

El método sigue la Norma IRAM 15.025 parte I para productos de la industria pesquera, siguiendo el método de determinación de las bases volátiles por la técnica de Antonacopoulos. Consiste en alcalinizar la muestra para permitir la volatilización de las aminas, luego se somete a una destilación por arrastre de vapor y los 
componentes básicos volátiles se absorben mediante un receptor ácido. La concentración de NBVT se determina mediante valoración de las bases absorbidas.

Se pesan $10 \mathrm{~g}$ de muestra y se colocan en la ampolla del aparato de Antonacopoulos. Se agrega $1 \mathrm{ml}$ de agua y 4 a 5 gotas de antiespumante de siliconas finalmente se incorporan $3 \mathrm{~g}$ de óxido de magnesio en la ampolla. Se conecta el tubo de conexión o puente y en el otro extremo del equipo se coloca un erlenmeyer con 10 $\mathrm{ml}$ de solución de ácido bórico 3\%, con 4 gotas de indicador Tashiro y $30 \mathrm{ml}$ de agua bidestilada. Se calienta el balón con la llave del embudo del aparato abierta, para evitar la condensación de agua en la ampolla del aparato, con el consiguiente retraso en el arrastre de las bases. Se lleva a ebullición, dejando la llave de la válvula abierta hasta que el vapor sale de manera continua y se cierra la llave. Se destila durante 17 minutos con el vástago del refrigerante sumergido y 3 minutos más con el vástago sin sumergir en el erlenmeyer. Se realiza la valoración con ácido clorhídrico $0,1 \mathrm{~N}$ con agitación constante del erlenmeyer hasta alcanzar el punto final cuando el color de la solución vira de verde a azul grisáceo (transparente). Si se llega a un color rojo violeta, es índice que se ha pasado del punto final. Los análisis se realizaron por duplicado.

Se realizan los cálculos:

$$
\mathrm{mg} \mathrm{NBV}=0,01401 \times 1000 \times \mathrm{V} \times \mathrm{N} \times 100 / \mathrm{M}
$$

Ecuación VI- 1

Donde:

V: $\mathrm{ml}$ de la solución valorada de ácido clorhídrico $0,1 \mathrm{~N}$ utilizado para la titulación.

$\mathrm{N}$ : normalidad de la solución valorada de ácido clorhídrico.

M: gramos de pescado

\section{VI.2.3. Recuentos microbianos}

Se tomaron $20 \mathrm{~g}$ de muestra y se homogeneizaron con $180 \mathrm{ml}$ de solución Ringuer, (peptona $0.1 \%-0.85 \%$ cloruro de sodio) en Stomacher durante 60 segundos a velocidad normal. Se realizaron diluciones seriadas de las diferentes muestras en tubos con peptona $0.1 \%-0.85 \%$ cloruro de sodio (Figuras VI - 3 ).

Las determinaciones se realizaron en profundidad de las diluciones correspondientes, al comienzo del almacenamiento y al finalizar los 6 meses. 


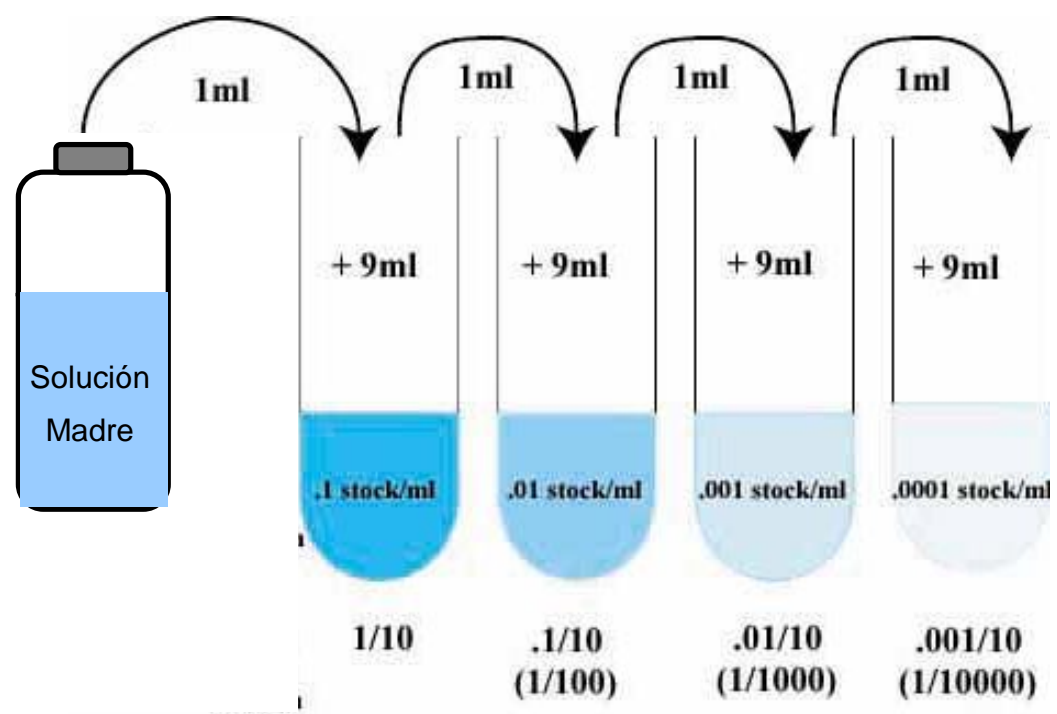

Figura VI- 3 Esquema de diluciones seriadas realizadas

Recuento de Microorganismos Totales y Psicrótrofos

Se utilizó el medio Plate Count Agar (PCA)

$\begin{array}{lll}\text { Peptona de caseína } & 5 & \mathrm{~g} / \mathrm{l} \\ \text { Extracto de levadura } & 2.5 & \mathrm{~g} / \mathrm{l} \\ \text { Glucosa } & 1 & \mathrm{~g} / \mathrm{l} \\ \text { Agar } & 14 & \mathrm{~g} / \mathrm{l} \\ \mathrm{Ph} & 7.0 \pm 0.2 & \mathrm{~g} / \mathrm{l}\end{array}$

Autoclavar a $121^{\circ} \mathrm{C}$ durante 15 minutos.

La incubación se realizó a $30^{\circ} \mathrm{C}$ durante 48 hs para recuento de microorganismos totales y a $4^{\circ} \mathrm{C}$ durante 5 días para el recuento de microorganismos psicrófilos. Los resultados fueron expresados como logUFC/g de muestra.

\section{VI.2.4. Determinación de Histamina}

La determinación de histamina fue realizada en el laboratorio de Físico-Química del SENASA, Centro Regional Zona Sur, ubicado en el puerto de Mar del Plata. La técnica oficial del SENASA para la determinación de Histamina se basa en una cromatografía en placa delgada (FAO, 1985). Consiste en una extracción de la histamina del pescado con metanol en caliente: $10 \mathrm{~g}$ de muestra se extraen con $10 \mathrm{ml}$ de metanol, se homogeniza y se lleva a $60^{\circ} \mathrm{C}$ durante 15 minutos. Se deja la muestra en metanol durante $24 \mathrm{hs}$ a $4^{\circ} \mathrm{C}$. Se siembran $10 \mu \mathrm{l}$ del extracto de las muestras y los patrones en placa de silica gel 60 . La placa de silica se debe activar a $100^{\circ} \mathrm{C}$ durante 4 minutos, se coloca en una cuba con mezcla de metanol - cloroformo - amoníaco y se 
deja correr. El patrón de histamina se prepara en diferentes concentración de 50, 100 y 200 ppm. Los resultados presentados por SENASA se expresan, según la intensidad que refleja el resultado de la histamina en la muestra con respecto a los patrones. Se informa negativo para muestras donde la intensidad es menor a la reflejada por el patrón de 50ppm o presencia dentro de los límites exigidos por SENASA y el CAA si la intensidad es menor a 100ppm; si la intensidad es mayor a 200ppm en las muestras, entonces exceden los límites permitidos y los lotes de producto se deben descartar o decomisar. El ensayo se realizó por triplicado en el desmenuzado de julio y diciembre.

\section{VI.2.5. Cuantificación de espinas}

Se utilizó una técnica enzimática, desarrollada en el INIDEP, que se basa en hidrolizar todo el tejido muscular para obtener las espinas y escamas limpias. Se empleó una proteasa alcalina de origen bacteriano Purazyme AS-60 (Nutring, Argentina) que tiene la capacidad de hidrolizar tejido blando. Los análisis se realizaron por triplicado: se agregó $1 \mathrm{ml}$ enzima en envases de vidrio junto con $50 \mathrm{~g}$ de filete de saraca. El pH y la temperatura se ajustan a los valores óptimos de reacción, 9 y $52^{\circ} \mathrm{C}$ respectivamente. Se dejó hasta hidrólisis total del tejido en baño de agua. Posteriormente, se desactivó la enzima por temperatura, llevando las muestras a $80^{\circ} \mathrm{C}$ durante 15 minutos. El hidrolizado se filtró a través de una malla de polietileno de 400 $\mu \mathrm{m}$ y las espinas se lavaron con agua destilada. Se secaron en estufa a $105^{\circ} \mathrm{C}$ hasta peso constante. Se determinó el contenido de espinas $g$ espinas/100g de desmenuzado y también se cuantifico el número de espinas enteras en músculo de saraca.

A su vez se estableció el porcentaje de recuperación de la técnica evaluada mediante el agregado espinas. Se determinó la recuperación de espinas enteras de saraca agregadas en músculo despinado de merluza. También se evaluó la recuperación de espinas fragmentadas, obtenidas de músculo de saraca picado en picadora comercial con una placa perforada de $3 \mathrm{~mm}$. Para determinar la recuperación de espinas enteras, se agregaron 40 espinas elegidas por su tamaño y forma (20 fragmentos chicos de menos de $3 \mathrm{~mm}$ de longitud, 10 costillas enteras de $10 \mathrm{~mm}$ de longitud, 5 espinas con ramificación en forma $Y$ y 5 con forma de $\Psi$ ). Para la determinación de recuperación de espinas fragmentadas se agregó 100mg de espinas de menos de $3 \mathrm{~mm}$ de longitud en $50 \mathrm{~g}$ de músculo despinado de merluza. La técnica se prosiguió de acuerdo a lo ensayado con el músculo de saraca. Se calculó el porcentaje de recuperación de la metodología puesta a punto en el INIDEP. 
VI.2.6. Presencia de parásitos.

Se examinaron 5 ejemplares de la especie Brevoortia aurea, se disecaron, separando las vísceras (estómago, intestino y ciegos), se colocaron en cápsulas de Petri para observar en detalle en el Laboratorio de Parasitología del INIDEP. Para este análisis macroscópico se usó agua para diluir los contenidos y proceder a la observación de los mismos mediante un microscopio binocular esteroscópico (Olympus Imaging Corp., Japón).

\section{VI.2.7. Análisis estadístico}

Explicado en III.2.7.

\section{VI.3. RESULTADOS Y DISCUSIÓN}

VI.3.1. Nitrógeno básico volátil total

Se observó que las muestras de julio presentaron valores de NBVT superiores a los de diciembre $(\mathrm{P}<0.05)$. Asimismo se encontró que las muestras de ambos estadios presentaron aumentos significativos durante su almacenamiento congelado, siendo la media de julio, al comienzo del almacenamiento $20.77 \pm 0.46 \mathrm{mg} / 100 \mathrm{~g}$ y al finalizarlo $23.89 \pm 0.98 \mathrm{mg} / 100 \mathrm{~g}$. En las muestras de diciembre los valores de NBVT obtenidos fueron $25.53 \pm 0.52 \mathrm{mg} / 100 \mathrm{~g}$ al comienzo del almacenamiento y $30.88 \pm$ $0.73 \mathrm{mg} / 100 \mathrm{~g}$ al finalizar el almacenamiento congelado (Figura VI - 4). Se observó que los valores iniciales fueron elevados desde el comienzo del almacenamiento, particularmente en el mes de diciembre. Esto se debe, posiblemente, al tiempo que demoró el pescado en llegar a puerto sin el enfriamiento adecuado, dado que ni bien desembarcó se lo acondicionó con hielo y en forma inmediata se realizaron los análisis. Este comportamiento fue observado en merluza capturada en verano y almacenada en hielo por Orbana y col. (2011) donde las muestras de merluza alcanzaba valores cercanos a $20 \mathrm{mg}$ NBVT/100 g de músculo al segundo día de almacenamiento. También observó que la época de captura influye significativamente en el NBVT para una misma especie. Las muestras de verano presentaron aumentos bruscos del NBVT y alcanzaron, en pocos días de almacenamiento en hielo, valores de $35 \mathrm{mg} / 100 \mathrm{~g}$ superiores a límites establecidos (Directive 95/149) para especies de la familia de los gádidos. Mientras que las muestras de invierno, si bien presentaban aumentos a lo largo del almacenamiento, eran paulatinos. Estas diferencias entre las épocas de captura pueden deberse a las diferentes temperaturas a las que están 
expuestos los peces mientras están en el agua y luego de la captura, hasta que son procesados. El almacenamiento a temperaturas superiores a los $10^{\circ} \mathrm{C}$ favorece el desarrollo de la mayoría de los microorganismos de deterioro.

Por otro lado, varios autores relacionan el aumento del NBVT durante el almacenamiento congelado con la pérdida de funcionalidad de las proteínas (Montero, Gómez-Guillén y Borderías, 1996; Valls, Paredes y González, 2006; Gomez-Estaca y col., 2010). El aumento de NBVT durante el almacenamiento congelado de pescado, se asocia a la conversión del óxido de trimetilamina por acción enzimatica a trimetilamina, dimetilamina y formaldehído, además de la desaminación de nucleótidos (Siddaiah y col., 2001). El formaldehído acumulado durante el almacenamiento congelado, reacciona con algunos grupos funcionales de las proteínas del músculo, favoreciendo la formación de agregados proteicos, por consiguiente la pérdida de la solubilidad de la proteína. Este proceso es más evidente en desmenuzado de pescado que en pescado entero o filete (Sikorski, 1994).

En este trabajo se observó que la muestra de diciembre superó los límites máximos establecidos para pescado según el CAA durante el periodo de almacenamiento ensayado, mientras que el desmenuzado de invierno se mantuvo por debajo del límite de $30 \mathrm{mg} / 100 \mathrm{~g}$. Siddaiah y col. (2001) en desmenuzado de carpa también observó un aumento significativo durante el almacenamiento congelado superando el límite de los $30 \mathrm{mg} / 100 \mathrm{~g}$ de músculo al quinto mes de almacenamiento congelado a $-18^{\circ} \mathrm{C}$.

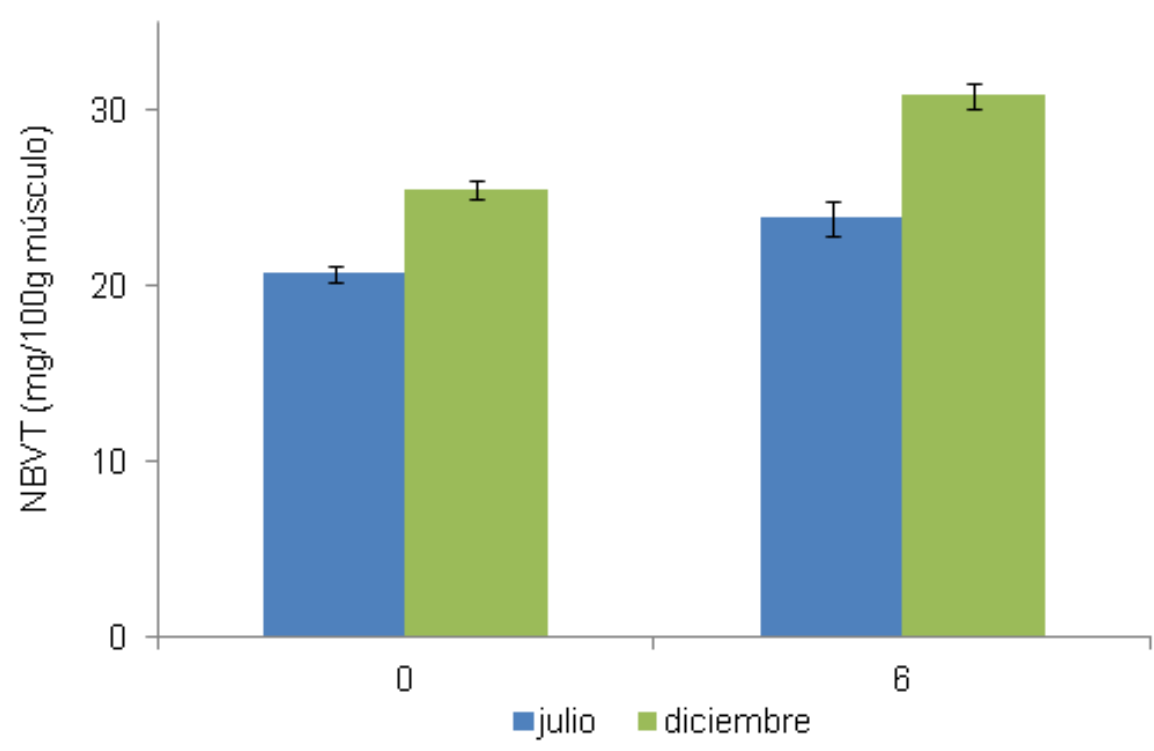

Figura VI - 4 : Variación en el contenido de NBVT durante el almacenamiento congelado de músculo desmenuzado de Brevoortia aurea capturado en diferentes estaciones; invierno y verano. La barra corresponde al error standard de la media. 


\section{VI.3.2. Recuentos microbianos}

La microflora presente en el músculo de saraca hasta la fecha no fue caracterizada por otros autores. Pero se sabe que en pescado de aguas templadas, predominan, en el deterioro durante su almacenamiento, las bacterias psicrotrófas las cuales crecen fácilmente y se multiplican a temperaturas bajas (Shewan, 1977; Surendran y Gopakumar, 1981). En este trabajo se observó que los recuentos de bacterias mesófilas totales (Figura VI - 5, PCA 30) dieron valores iniciales cercanos a 5 $\log$ UFC/g. La muestra de julio presentó un recuento menor que la muestra de diciembre. Por lo cual se observa que la muestra de julio tenía una carga microbiana menor lo que también podría estar asociado a la diferencia de temperatura entre las estaciones evaluadas, donde las altas temperaturas del verano favorecen su desarrollo. A su vez se observó que los niveles de microorganismos mesófilos totales se redujeron significativamente durante el almacenamiento congelado a $-25^{\circ} \mathrm{C}$.

El recuento de los psicrófilos totales (Figura VI - 5, PCA 4) en los desmenuzados de julio y diciembre también presentaron una reducción significativa durante los meses de almacenamiento. Las bacterias psicrófilas gram negativas son el mayor grupo de microorganismos responsables del deterioro aeróbico del pescado fresco durante su almacenamiento (Gram y Huss, 1996). En este trabajo el valor inicial de los microorganismos psicrófilos estuvieron en el orden de $3.5 \pm 0.15 \mathrm{log}$ UFC/g para el desmenuzado de julio mientras que el desmenuzado de diciembre presentó valores mayores $4.8 \pm 0.24 \log$ UFC/g. Valores similares se observaron en salmón fresco recién capturado 3.6 log UFC/ (Sallam, 2007).
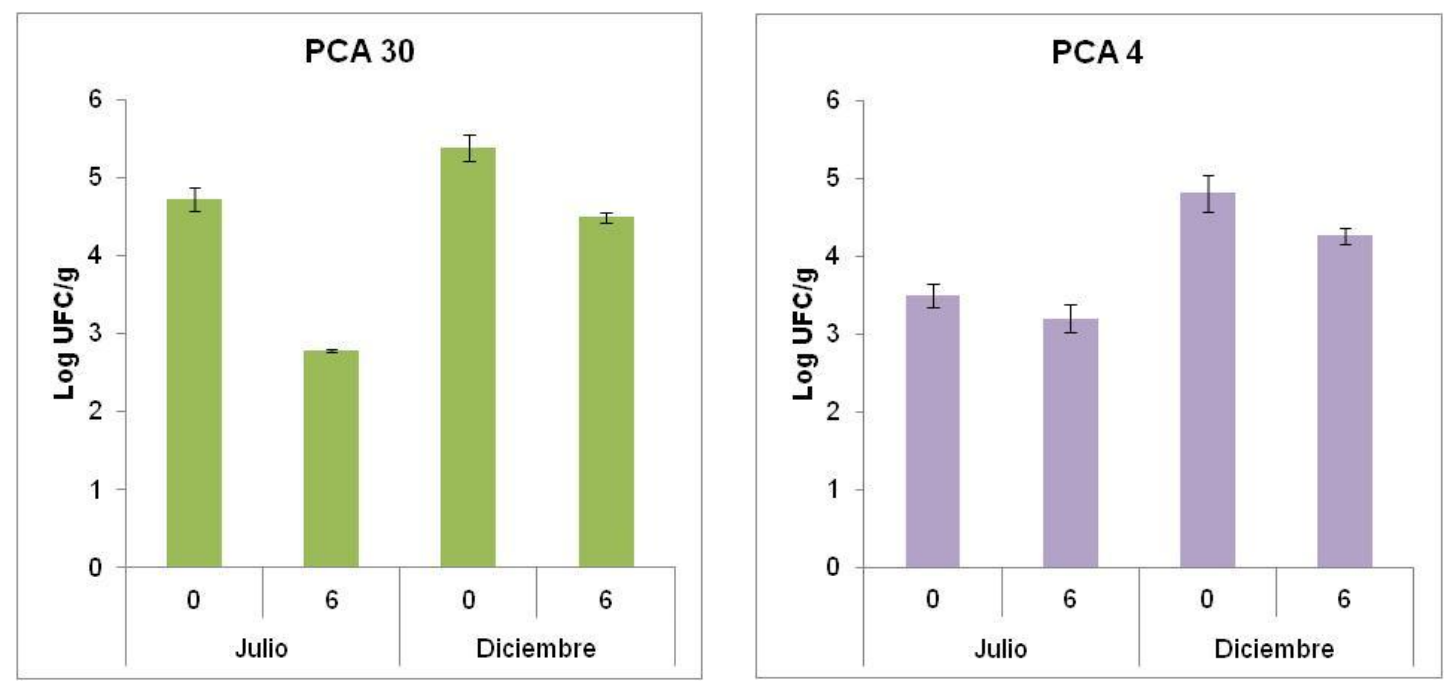

Figura VI - 5: Recuento de microorganismos aerobios. Izquierda: Mesofilos (PCA 30);

Derecha: Psicrófilos (PCA 30). La barra corresponde al error standard de la media. 


\section{VI.3.3. Histamina}

En los resultados obtenidos para el análisis de histamina en músculo de desmenuzado de saraca, el valor fue negativo en las muestras al inicio y al final del almacenamiento congelado de ambos periodos, julio y diciembre (Figura VI - 6). La ausencia de histamina detectable por esta técnica en el desmenuzado de pescado puede deberse a dos razones. Por un lado, al adecuado mantenimiento del pescado a temperaturas por debajo de los $8 \stackrel{\circ}{\circ}$; de esta manera, el pescado utilizado como materia prima se mantuvo por debajo de la temperatura de desarrollo de los microorganismos descarboxiladores de la histidina desde su captura y durante su transporte al Instituto. Ozugul y col. (2002) observaron valores elevados de histamina en muestras de arenque en los ejemplares que se almacenaron sin hielo. Por otro lado, en la guía de Peligros y Control de Pescados y Productos Pesqueros de la FDA (2001) en el Capítulo 3 nombra a las especies marinas y su relación con los diversos peligros químicos, biológicos y físicos. En esta lista el género Brevoortia spp., es citada como una especie sin riesgo de formar histamina. Por lo cual se podría pensar también que la saraca es una especie segura en relación a la formación de histamina a pesar de pertenecer a la familia de Cupleidos.

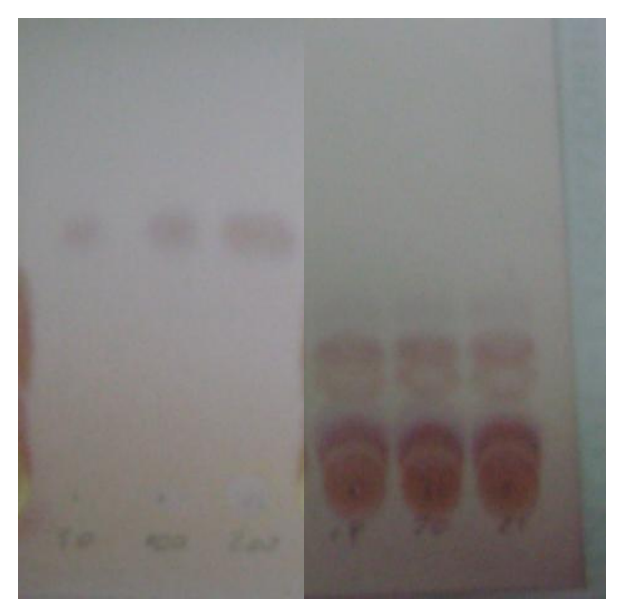

Figura VI - 6: Cromatografía capa delgada de sílica gel para la determinación de histamina. Izquierda: patrones 50, 100 y 200 ppm. Derecha: triplicado con resultado negativo de muestra de desmenuzado de saraca.

\section{VI.3.4. Cuantificación de espinas}

Se observó que las muestras de filetes de saraca presentaban $0.287 \pm 0.032 \mathrm{~g}$ de espinas por $100 \mathrm{~g}$ de músculo. La presencia de espinas es considerada como un defecto, según el Codex, para producto declarado sin espinas. Como ya se describió, 
el Codex establece los tamaños y la cantidad de espinas que pueden estar presentes por kilogramos de producto. En los filetes de saraca se observó un valor elevado en el recuento de espinas. El recuento indicó que cada $100 \mathrm{~g}$ de músculo de saraca contiene $310 \pm 109$ espinas. Incluso todas las espinas eran de más de $1 \mathrm{~cm}$ de longitud alcanzando los $2.5 \mathrm{~cm}$ y muchas presentaban estructura ramificada (Figura VI - 7). Las espinas con estas características son consideradas peligrosas, en el caso de tragarlas, son las que causan ahogo en los consumidores. Las espinas de $0.6 \mathrm{~mm} o$ mayor longitud son consideradas peligrosas u objetables, sobre todo depende de la forma y la rigidez que presente la espina (Wong, Lau, Yamamoto, 1978).

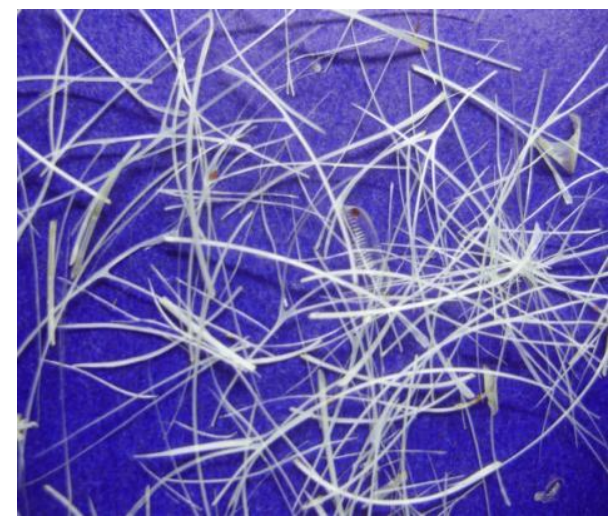

Figura VI- 7: Espinas extraídas con enzima proteolítica en músculo de saraca.

Espinas simples y ramificadas.

En el caso del desmenuzado de saraca se observó un contenido mucho menor al observado en el músculo entero de saraca. A su vez se observó que el desmenuzado de julio presentó un contenido menor de fragmentos de espinas que el de diciembre, correspondiendo en julio $0.007 \pm 0.001 \mathrm{~g} / 100 \mathrm{~g}$ de desmenuzado y en diciembre $0.021 \pm 0.002 \mathrm{~g} / 100 \mathrm{~g}$ de desmenuzado. Esta gran diferencia se debe a que el desmenuzado de julio presentaba mayor contenido de lípidos en el músculo, casi 10 veces más comparado al de diciembre. Como se observó en el Capítulo III sección 3.2. el factor de condición eviscerado de los ejemplares de julio fue mayor respecto a diciembre, lo que se asocia a ejemplares con más contenido de lípidos en músculo, con mayor masa corporal que los ejemplares de diciembre. Los recuentos en este caso fueron $89 \pm 16$ fragmentos de espinas en desmenuzado de julio y $221 \pm 52$ en el de diciembre (Figura VI - 8). Si bien el esqueleto de los peces es el mismo a lo largo del año para ejemplares de la misma talla, un mayor contenido de grasa en músculo hace que sea menor el porcentaje de espinas en la relación de la muestra tomada. En el caso de las espinas presentes de los desmenuzados de julio y diciembre, eran fragmentos de las espinas intramusculares del filete. Durante el proceso de 
separación, al pasar el filete entre la banda y el tambor perforado, las espinas se fragmentan por la presión que ejerce la banda contra el músculo. Debido al tamaño del orificio del tambor $(3 \mathrm{~mm}$ ) la mayoría de los fragmentos no superaban esa longitud. Este tamaño de espina no es peligroso y es poco percibido por los consumidores.

Wong, Lau y Yamamoto (1978) realizaron un trabajo para evaluar el efecto del tamaño de la perforación del equipo separador, con respecto al número y tamaño de las espinas que pasan al desmenuzado. Evaluaron diferentes especies, una de ellas el arenque. Propusieron una técnica que utiliza urea para solubilizar el músculo y separar las espinas. Observaron que a mayor tamaño de la perforación, mayor número de espinas y fragmentos de espina pasaban al desmenuzado. En el caso particular del arenque, que presenta espinas finas como la saraca, observaron que utilizando un tambor perforado con orificio de $3 \mathrm{~mm}$, obtuvieron un recuento de $35.0 \pm 13.2$ espinas cada 100 gramos de músculo y expresado en gramos fue de $0.007 \pm 0.003 \mathrm{~g} / 100 \mathrm{~g}$ de músculo desmenuzado de arenque, estos resultados son similares a los observados en este trabajo de Tesis. También observaron que las espinas de arenque son finas y frágiles, por lo cual son menos peligrosas para el consumidor. Los mismos autores describen que las espinas provenientes de otra especie magra, como Rockfish (Sebastes sp.), de 4 a $5 \mathrm{~mm}$ de largo, por su forma y dureza, son más peligrosas para el consumidor que las de arenque de $10 \mathrm{~mm}$.

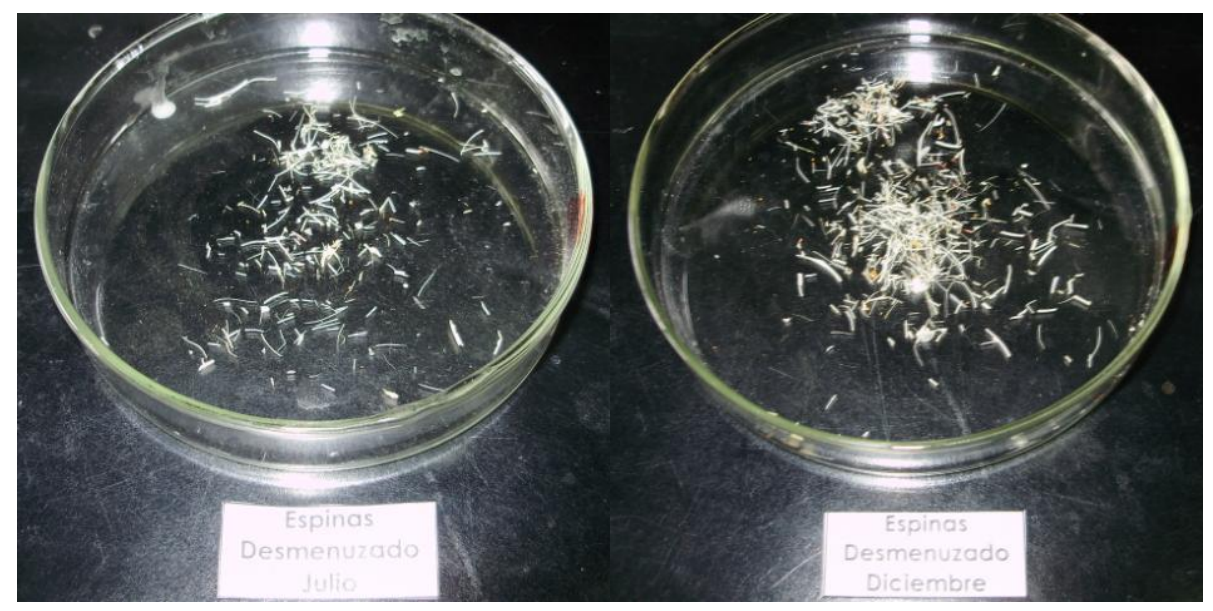

Figura VI - 8: Espinas extraídas con enzima proteolítica en desmenuzado de saraca capturados en: izquierda, julio; derecha, diciembre.

A su vez se realizó un ensayo utilizando las espinas recuperadas mediante esta técnica y se mezcló con $50 \mathrm{~g}$ de músculo de merluza sin espinas obtenido de filete de merluza frescos con corte en $\mathrm{V}$. Para evaluar la sensibilidad del método, se agregaron un total de 40 espinas de músculo de saraca obtenidas previamente mediante la 
misma técnica. Las espinas de saraca son muy ramificadas, por lo cual para este ensayo, como ya se describió, se utilizaron espinas de diferente forma (20 fragmentos chicos, 10 costillas enteras, 5 espinas con ramificación en forma $Y$ y 5 con forma de $\Psi)$. Se observó que la recuperación de las espinas a partir de este método fue elevado. De 40 espinas se recuperaron $39 \pm 1$, lo que equivale un $97.5 \pm 1.4 \%$ de recuperación por la técnica. Se observó en todos las repeticiones, que las espinas ramificadas se recuperaron al $100 \%$ y las pocas espinas que se perdieron correspondieron a fragmentos y costillas finas que pasaban a través de la malla de filtración. La recuperación de los fragmentos agregados fue menor a la observada en las espinas enteras. De los $100 \pm 10 \mathrm{mg}$ de espinas agregadas, se recuperaron $92 \pm 1$ $\mathrm{mg}$, correspondiente a una recuperación del $89.6 \pm 1.24 \%$ de las espinas fraccionadas.

Las espinas chicas no son un peligro para el consumidor además las espinas de saraca son flexibles y blandas por lo cual no serían percibidos por los consumidores a la hora de ingerirlas (Patashnik, Kudo y Miyauchi, 1974; Yamamoto y Wong, 1974), además luego de los tratamientos térmicos las espinas se vuelven más blandas (Hale y col., 1991). El método desarrollado con la enzima proteolítica es sencillo, que permite cuantificar y clasificar con gran exactitud las espinas presentes en músculo, ya sea de pescado entero o desmenuzado, por lo cual esta técnica es utilizable como un método para determinar uno de los aspectos que hacen a la seguridad para el consumidor.

\section{VI.3.5. Presencia de parásitos.}

Durante la búsqueda de parásitos, no se observaron helmintos en ninguno de los tejidos analizados. Como se describió en el Capítulo 1, la saraca presenta un comportamiento particular en su alimentación, durante la adultez es una de la pocas especies que se vuelve filtrador de fitoplancton. Existe poca información sobre datos relacionados a la presencia de parásitos en Brevoortia aurea, Sanchez (1989) estudió la dieta y el aparato digestivo de esta especie. Observó que presenta un intestino largo y se caracteriza por presentar un enrollamiento sobre sí mismo, que se denomina disco espiral. La saraca presenta un cociente intestinal de alrededor de 2.7. Las especies que no son fitoplantofagas presentan un cociente menor a 1.3. Según la FDA (2001) las especies de Brevoortia spp. no son un peligro en relación a los parásitos. Esta particularidad se debe principalmente a su dieta, al ser fitoplantófago es menos probable la contaminación con parásitos. 


\section{VI.4. CONCLUSIÓNES}

En el pescado almacenado congelado, se observó un aumento significativo en el valor de nitrógeno básico volátil total a lo largo del mismo. Los valores iniciales de NBVT correspondientes al desmenuzado de diciembre fueron elevados, mayores que los de julio, pero ambos aumentaron durante todo el almacenamiento. En el caso del desmenuzado de diciembre, se podría relacionar el valor elevado del NBVT con las altas temperaturas que corresponden a esa época del año y la falta de refrigeración desde la captura hasta el desembarque. Por lo cual, para evitar valores iniciales elevados sería aconsejable promover la inmediata refrigeración del pescado capturado utilizando la cantidad adecuada de hielo. El desmenuzado de diciembre presentó al sexto mes valores de NBVT superiores al límite establecido por CAA (30 mg NBVT / $100 \mathrm{~g}$ de músculo).

Con respecto a la histamina, no se la detectó en ninguna de las muestras analizadas, pese a que los altos valores de NBVT correspondientes al pescado de diciembre indicarían que las muestras estuvieron expuestas a altas temperaturas. Esto permite inferir que la saraca no es una especie potencialmente peligrosa en relación a la histamina.

Los recuentos microbiológicos estuvieron dentro de los límites establecidos, presentando recuentos menores a $10^{7} \mathrm{UFC} / \mathrm{g}$ de músculo para las bacterias psicrótrofas; encontrando que las muestras de diciembre presentaron recuentos superiores a las de julio. A su vez se observó una reducción de los recuentos microbianos al avanzar el tiempo de almacenamiento congelado a $-25^{\circ} \mathrm{C}$.

La técnica desarrollada para evaluar el contenido de espinas utilizando enzima proteolítica presentó buena reproducibilidad y valores de recuperación elevados, siendo su ejecución simple. Es un método sencillo para cuantificar y clasificar las espinas presentes en desmenuzado y de esta manera determinar uno de los riesgos físicos que hacen a la calidad higiénico sanitaria del mismo. Con respecto al tamaño, forma y rigidez de las espinas enteras de músculo de saraca se encontró que, si bien son largas, son finas y flexibles como en el arenque, por lo que este tipo de espinas no presentan riesgo de ahogo para los consumidores.

Por último, el riesgo de infestación con parásitos por consumo de saraca parasitada es bajo, ya que por ser una especie fitoplanctófaga no se parasita. 



\section{CAPITULO VII \\ DESARROLLO DE CONFORMADOS DE SARACA}

(Brevoortia aurea)

\section{VII.1 Características en el consumo actual}

El estilo de vida de las poblaciones urbanas ha cambiando en forma notable en las últimas décadas, el ritmo es cada vez más acelerado y las personas están siempre muy atareadas. Esto repercute en forma negativa particularmente en los hábitos alimentarios de la población y en el valor nutricional de los alimentos que se consumen. Debido a esto la población se orienta hacia el consumo de alimentos de expendio rápido, conocidas como "de paso", "rápidas" o "fast food". Estas preparaciones se caracterizan por la abundancia de hidratos de carbono y por ser ricas en ácidos grasos saturados e insaturados trans. A estas pautas de consumo se suma la poca actividad física que generan las comodidades de la vida moderna, lo que produce un desequilibrio energético, con un exceso de calorías en la ingesta. Los medios de comunicación, como internet o la televisión, poseen un rol sobre nuestra vida diaria cada vez más importante, lo que favorece el sedentarismo y produce un gasto menor de energía fomentando el desequilibrio energético. Todo ello conlleva al desarrollo de diferentes enfermedades crónicas no transmisibles, como las enfermedades cardiovasculares, la diabetes, determinados tipos de cánceres e hipercolesterolemia en adultos.

El consumo aparente de grasas por habitante en la Argentina, ha aumentado entre 10 y $15 \mathrm{~g}$ diarios entre la década del 60 y los últimos años. De esta manera, el aporte de calorías de las grasas en la dieta media Argentina pasó de $29.9 \%$ a más de $32 \%$, apenas por encima del valor recomendado (30\%) por organismos internacionales y comités de expertos. No obstante ese valor es inferior al de países industrializados que tiene un aporte entre el 35 y el 40 \% (Britos y col., 2004; Claret y col., 2012). Además, el consumo de lípidos debe mantener un balance adecuado entre los ácidos grasos saturados, los ácidos grasos mono-insaturados y poli-insaturados.

En nuestro país no se dispone de una encuesta nacional que informe sobre el estado nutricional de la población. Lamentablemente sólo se accede a información proveniente de diversos estudios con objetivos, metodologías y criterios de diagnóstico diferentes entre sí. Se estima que en Argentina el sobrepeso afecta a un $20 \%$ de niños de todas las clases sociales, lo cual podría transformarse en un riesgo a los 30 años de edad. Siete de cada diez niños nacen en la pobreza y muchos sufren de 
obesidad (Calvo, 2004 y ENFR, 2011). En 2010, nuestro país lideraba los porcentajes de obesidad en niños menores de 5 años en América Latina, con un 7,3\% de prevalencia (FAO, 2010) y en un estudio de la Sociedad Argentina de Pediatría se detectó que $20,8 \%$ de los niños y adolecentes, de 10 a 19 años, presentaban sobrepeso y 5,4\% obesidad (Kovalskys y col., 2003). La prevalencia nacional de obesidad fue de 18\% (ENFR, 2011), significativamente mayor a la cifra hallada en la encuentra nacional factores de riesgo (ENFR) realizada en 2005 (14,6\%). Dicho incremento se observó en todas las regiones y en casi todas las provincias. Sin embargo, a nivel nacional no se observó un aumento significativo del sobrepeso $(34,4 \%$ a $35,4 \%)$. Sobre la base de datos de anatomía patológica se conoce que el proceso ateroesclerótico se inicia en la infancia y el grado de extensión de las lesiones en niños y adultos jóvenes se correlaciona con la presencia de los mismos factores de riesgo identificados en adultos. La obesidad infantil es una crisis de salud pública que puede prevenirse y su solución consiste en cambiar las opciones de alimentación y las actividades de los niños (Britos y col., 2004).

Según la Organización Mundial de la Salud (OMS, 2004, 2008; European Commission, 2011), la alimentación debe proveer al organismo la materia y energía, a partir de sus nutrientes (hidratos de carbono, proteínas, lípidos, vitaminas y minerales), necesarios para que una persona reponga el gasto diario y genere un excedente para períodos de crecimiento. Los requerimientos varían de individuo a individuo y dependen fundamentalmente del sexo, edad, actividad física, estado fisiológico, salud y factores genéticos. Una dieta saludable debe mantener un balance entre los nutrientes. Para individuos sanos el aporte calórico debe provenir aproximadamente en un 50 - $65 \%$ de los hidratos de carbono, 20 - $30 \%$ de lípidos y $15-20 \%$ de proteínas (Olivares y Zacarías, 2002).

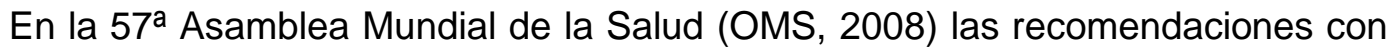
respecto a la dieta incluyeron:

- Lograr un equilibrio energético y un peso normal;

- Limitar la ingesta energética procedente de las grasas, sustituir las grasas saturadas por grasas insaturadas y tratar de eliminar los ácidos grasos trans;

- Aumentar el consumo de frutas y hortalizas, así como de legumbres, cereales integrales y frutos secos;

- Limitar la ingesta de azúcares libres;

- Limitar la ingesta de sal (sodio) de toda procedencia y consumir sal yodada. 
Para seguir estas recomendaciones la población debe tener accesibilidad y disponibilidad de alimentos sanos. Esto constituye un reto para los tecnólogos de alimentos, especialmente los orientados al desarrollo de productos, dado que se presenta la necesidad de crear alternativas saludables a las propuestas actuales, que tengan gran aceptación en la población infantil como una forma de contribuir a una alimentación sana desde los primeros años de vida.

\section{VII.1.1. Características en el consumo de pescado}

El pescado, como se describió en los Capítulos previos, además de ser una fuente de proteínas, presenta beneficios para la salud principalmente debido a su contenido de ácidos grasos poli-insaturados de cadena larga. El consumo de pescado en los países en desarrollo y desarrollados ha aumentado considerablemente, junto con el crecimiento económico y la tendencia alimenticia hacia alimentos saludables. Este incremento está asociado con las modificaciones en los hábitos de consumo, en algunos grupos de población, particularmente urbanos. Además se observa una toma de conciencia por parte de los responsables de la salud pública debido a la necesidad de fomentar una alimentación equilibrada para evitar diversas enfermedades que se generan por una alimentación inadecuada. En los países en desarrollo, la mejora del poder adquisitivo dio un impulso al consumo de pescado, tanto en los hogares como fuera de la casa y en forma de productos de fácil preparación o listos para su consumo (Manca, 2004).

Por otro lado, la situación de los sectores menos favorecidos de muchos países subdesarrollados presenta una notable escasez de proteína de origen animal en la dieta, constituyéndose en una de las deficiencias más extendidas en la nutrición actual de dichos países. La carencia de proteínas de origen animal en la dieta, se debe principalmente a la falta de fuentes de proteínas de bajo costo. Sin embargo, en muchos países desarrollados o aún en los sectores de ingresos medios y altos de los países menos favorecidos, el pescado adquiere cada día más importancia como fuente proteica en la dieta.

Desde hace varios años la tecnología de los productos pesqueros trabaja en la optimización del uso del pescado para consumo humano; ya sea en la revalorización de las especies pesqueras de bajo costo o las que todavía se descartan a bordo de las embarcaciones pesqueras porque no tienen aceptación en el mercado. Organismos internacionales como la FAO estimulan esta orientación como se demuestra en el Artículo 11 del Código de Conducta para la Pesca Responsable (FAO, 2013). La utilización de especies de bajo valor comercial como materia prima, es una buena 
fuente de proteína animal de alto valor biológico a precio competitivo, lo que permite que sea accesible para toda la comunidad. Por otro lado y con una visión ecologista, darle valor a especies consideradas de descarte, es una importante contribución a la sostenibilidad de las pesquerías.

Como ya se describió en los Capítulos anteriores, una de las tecnologías disponibles para la industrialización del pescado es la recuperación mecánica de la carne utilizando equipos separadores de piel y espinas. Esta tecnología se ha difundido en el mundo, con gran éxito, desde comienzos de los años '70 del siglo pasado. Su utilización permite aumentar el aprovechamiento de la porción de músculo comestible que queda adherido al espinazo luego del proceso de fileteado o los recortes del "prolijado" del filet. Por otro lado, el músculo de pescado desmenuzado, dada su versatilidad, es una materia prima de gran potencial en el desarrollo de nuevos productos pesqueros. Cabe destacar que cada especie presenta diferentes características específicas, desde el punto de vista tecnológico, determinando diferencias en el procesamiento y posterior destino de su carne. A su vez, como hemos visto en los Capítulos previos de esta Tesis Doctoral, dentro de una misma especie pueden existir diferencias considerables en su composición a lo largo del ciclo biológico, y estas variaciones son las que determinan sus propiedades funcionales y los posibles usos de dicha materia prima. La carne de pescado una vez desmenuzada es más inestable que la carne del músculo intacto (Grantham, 1981; Babbitt, 1986) por lo cual debe ser procesada o congelada inmediatamente luego de su obtención.

Por otro lado, una toma de conciencia a nivel mundial de la necesidad de optimizar la utilización de los recursos pesqueros, es decir, obtener la mayor cantidad de productos pesqueros posibles, aprovechando lo que anteriormente era considerado residuo y se desechaba. Además, esa toma de conciencia se hace extensiva a la necesidad de aumentar el valor agregado de sus productos como el medio más idóneo para aumentar las ganancias de las empresas (Manca, 2004)

\section{VII.1.2. Productos estructurados a partir de desmenuzado de pescado}

La utilización de desmenuzado de pescado es muy versátil, permite reformular y ampliar la oferta al mercado de un gran abanico de productos pesqueros innovadores, atractivos y más saludables a precios competitivos. Al diversificar la oferta de productos se logra atraer a nuevos consumidores que por diferentes razones no son consumidores habituales de pescado. Por otro lado al aumentar la variedad de productos, permite ofrecer nuevas alternativas que incluyan a los consumidores no habituados al consumo de pescado. En la actualidad se lo utiliza para desarrollar 
productos como hamburguesas, bastones, salchichas y también es la base para el proceso de elaboración del surimi, con el cual se desarrollan una infinidad de productos de imitación. El desmenuzado de pescado, es una matriz que permite la incorporación de diversos ingredientes, lo que le otorga una gran versatilidad para desarrollar un sinfín de productos, de diferentes sabores, colores, texturas, e incluso formas con mínimos procesos (Dongdong, 1994; Ninan, Bindu y Joseph, 2010). Dentro de esta versatilidad para la elaboración de productos, se le puede incorporar no sólo ingredientes con finalidad tecnológica, también permite la inclusión de productos nutraceúticos, como pueden ser fibras, ácidos grasos, fitoesteroles, etc., dando lugar al desarrollo de alimentos funcionales, productos buscados por las nuevas generaciones de consumidores por sus beneficios adicionales para la salud (SánchezAlonso, Hají-Maleki y Borderías, 2007).

Las actuales tendencias de los consumidores se inclinan por los "productos sanos" y de "aspecto fresco", de fácil y rápida preparación o incluso listos para consumir. Este concepto incluye las consideradas "comidas rápidas" como las hamburguesas, salchichas, etc. En Argentina por tradición y hábito, los productos de éste tipo más consumidos son los provenientes de carne vacuna, que por su composición rica en ácidos grasos saturados son poco saludables. Sin embargo, en trabajos previos del grupo se diseñaron medallones de carne vacuna saludables sustituyendo las grasas saturadas por poli-insaturadas (Pennisi y col., 2010).

En Argentina la reglamentación para este tipo de producto se encuentra establecida en el Reglamento de Inspección del SENASA (Decreto 4238/68, Capítulo 16: Chacinados, Art.16.9.24). Dicho artículo define con el nombre de "Hamburgués o bife a la hamburguesa" y establece: "Se entiende por hamburgués o bife a la hamburguesa, al producto de forma plana, elaborado exclusivamente con carne vacuna picada con un contenido graso promedio en el lote no mayor al veinte por ciento $(20 \%)$, con o sin el agregado de antioxidantes, aromatizantes, saborizantes, especias, exaltadores de sabor, estabilizantes, (únicamente fosfatos y polifosfatos) estabilizantes de color (excluyendo nitritos y nitratos) autorizados. No se admite el agregado de colorantes naturales y/o artificiales. En caso de utilizarse carnes distintas de la vacuna, deberá denominarse "Hamburgués de ....." o "Bife a la Hamburguesa de ..." seguido de la denominación de la o de las especies que lo componen". Por lo cual, este tipo de alimentos se pueden desarrollar con diversas carnes como pollo y pescado. También se los puede rediseñar, para que sea saludable, a partir de carne de pescado manteniendo, en la medida de lo posible, las características organolépticas que los caracterizan. Siguiendo la tendencia mundial hacia la búsqueda de alimentos más saludables y el hábito ya impuesto del consumo de "comidas 
rápidas" se buscó evaluar el uso de la carne de saraca para el desarrollo de este tipo de producto. Por lo general los conformados comerciales de pescado, como las hamburguesas, porciones o bastones, se realizan principalmente con desmenuzado de merluza. La formulación puede contener además, grasa o aceite, pan rallado, harina, almidones, agua, leche, condimentos, sal y, en algunos casos derivados de soja. En Argentina estos productos se comercializan rebosados con pan rallado y se someten a un rápida fritura superficial que fija el rebozado y le otorga el color y sabor característicos. El proceso de fritado hace más atractivo al producto desde el punto de vista organoléptico al mismo tiempo que disminuye su característica de saludable. Por otro lado, la incorporación de pan rallado tanto en la cobertura como en la formulación, inhabilita su consumo a las personas que padecen de celiaquía. Como se describió con anterioridad, la especie Brevoortia aurea es una especie de descarte por lo cual tiene poco valor en el mercado. A su vez, a partir de los ensayos previos a esta etapa de desarrollo, observamos que la carne de saraca, además de ser una buena fuente de proteínas, aporta cantidades importantes de ácidos grasos poli-insaturados saludables, suficientes para cubrir los requerimientos diarios. Por todo ello, evaluar su utilidad como materia prima para desarrollar un producto masivo como son las hamburguesas, es una buena opción para otorgarle mayor valor agregado a esta especie a través de un producto saludable y accesible a amplios estratos económicos de consumidores.

En esta etapa de la Tesis el objetivo del trabajo fue diseñar y evaluar formulaciones bajo la denominación de bife a la hamburguesa ${ }^{1}$ elaborados con desmenuzado de saraca, aptas para ser consumidas luego de un proceso de cocción "a la plancha". Se realizaron varios ensayos preliminares basados en formulaciones comerciales básicas, pero se decidió realizar algunos cambios importantes de manera de reformularlas para obtener un producto saludable. Así, se eliminó el pan rallado de la mezcla para obtener un producto accesible a personas celiacas. También se redujo el contenido de cloruro de sodio, cercano al $2 \%$, que suele usar la industria. Se siguieron las recomendaciones de la FDA, para reducir el sodio de la dieta, sin que el producto pierda sus atributos sensoriales. Se utilizó hexametafosfato de sodio y ácido ascórbico para reforzar el efecto de los antioxidantes, ambos actuando como secuestrante de metales y donador de protones como regenerador de los compuestos

${ }^{1}$ En esta Tesis, siguiendo la reglamentación se utiliza la denominación del producto "bife de hamburguesa de saraca" o la denominada de manera resumida en "hamburguesa de saraca" o bien "conformado de saraca". 
fenólicos. Para mejorar la palatabilidad se incorporó, en lugar de grasa vacuna o porcina, aceite de girasol alto oleico y aprovechando la matriz de pescado, se adicionó aceite de pescado refinado y desodorizado. Por otro lado se sustituyó la leche en polvo por concentrado de proteína de suero lácteo (WPC) que presenta mayor capacidad emulsificante, para mejorar la jugosidad, disminuir el contenido de lactosa y favorecer la palatabilidad del producto. Durante las últimas décadas, la utilización de WPC despierta gran interés para el desarrollo de productos alimenticios como las formulas infantiles, dietéticas y los alimentos saludables. Las proteínas de suero se utilizan en productos cárnicos emulsionados, tales como salchichas tipo Viena y mortadela, así como en productos picados, como salchichas parrilleras y carne para hamburguesas, por sus propiedades emulsificantes, estabilizantes, humectantes y ligantes de grasa. EI WPC, además, aporta elementos traza (hierro, cobre y manganeso) y compuestos bioactivos. Algunas de las funciones bioactivas de las proteínas y péptidos presentes en el WPC son: transportador de provitamina A, intervienen en la síntesis de lactosa, transportador de ácidos grasos, actividad inmunológica, agente bacteriostático y bactericida (de Wit, 1998). Las propiedades funcionales más importantes de las proteínas de suero en aplicaciones cárnicas son: solubilidad, fijación de agua y viscosidad, emulsificación, adhesión, gelación y características organolépticas. Otras propiedades de estas proteínas, como dispersión, formación de film comestible, actividad antioxidante y pardeamiento, contribuyen a la funcionalidad, pero son de menor importancia en un producto cárnico. Varios autores observaron la capacidad antioxidante del las proteínas del suero de leche aplicados a emulsiones de aceite en agua actuando en la superficie de la gota dispersa o en la fase acuosa. El mecanismo como antioxidante de las proteínas de suero de leche es atribuida a: (1) la habilidad de producir cambios catiónicos en la superficie de las gotas de la emulsión, actuando como repelente de los metales; (2) formando un film viscoelástico que protege la interfase de las gotas, minimizando la hidroperoxidación de los lípidos por la acción de los metales; (3) quelando metales prooxidantes e (4) inactiva radicales libres a través de los grupos sulfihidrilos y otros amino ácidos (Tong y col., 2000a y b; Hu, McClements y Decker, 2003).

El objetivo de este Capítulo fue estudiar el efecto de la incorporación de antioxidantes naturales y concentrado de suero lácteo (WPC) en la oxidación lipídica de hamburguesas de saraca congeladas y almacenadas a $-25^{\circ} \mathrm{C}$ durante 6 meses. Dado que el WPC con 40\% de contenido proteico (WPC40) es producido en Argentina, mientras que el WPC con un $80 \%$ de proteínas (WPC80) debe ser importado por falta de tecnología para su producción y tiene un costo bastante más elevado, se utilizaron ambos concentrados de suero lácteo en el estudio para comprobar si la concentración 
de proteína en el WPC influía en la oxidación lipídica de los conformados almacenados a $-25^{\circ} \mathrm{C}$.

Se compararon, además, los resultados obtenidos tanto con la incorporación de dos concentraciones de un extracto de semillas de uva (antioxidantes naturales), un antioxidante sintético (BHTQ) y un control sin agregado de antioxidantes. En el Capítulo $V$ se había verificado que este antioxidante fue efectivo frente a la oxidación de los lípidos propios del pescado durante el almacenamiento congelado de músculo desmenuzado de saraca. El BHTQ, es ampliamente utilizado como antioxidante en alimentos de origen marino por su efectividad en prevenir la oxidación de ácidos grasos poli-insaturados (Ke, Nash y Ackman, 1977; Farkas y col., 1997; Kaitaranta, 1992); también fue ensayado previamente en esta Tesis durante el almacenamiento congelado de desmenuzado de saraca (Capítulo V).

Se realizaron ensayos de almacenamiento a $-25^{\circ} \mathrm{C}$ y se analizaron los cambios debidos al tiempo de almacenamiento congelado en el rendimiento, la retención de agua y lípidos, color, jugosidad y textura de los conformados cocidos, aporte calórico y contenido de ácidos grasos poli-insaturados. Se comparó las características obtenidas utilizando formulaciones con extracto de semillas de uva como antioxidante con formulaciones control, empleando en los dos casos ambos tipos de concentrado de suero lácteo.

\section{VII.2. MATERIALES Y MÉTODOS}

VII.2.1. Materia prima y preparación de las muestras

Para este trabajo experimental se utilizaron ejemplares de saraca capturados en mayo de 2011, en la bahía de Samborombón, en las costas de la provincia de Buenos Aires. El muestreo se realizó sobre un total de 4 cajones $(80.94 \mathrm{~kg})$ de pescado fresco acondicionado en cajones con hielo que se transportó en el día hasta el Instituto Nacional de Investigación y Desarrollo Pesquero (INIDEP). Los ejemplares fueron eviscerados, lavados, fileteados, cuereados manualmente y para la obtención del desmenuzado sin espinas se procedió tal como fue descripto previamente en el Capítulo IV.2.1.

\section{Otros ingredientes y aditivos}

En el año 2011 no se pudo obtener materia prima hasta el mes de mayo, presentando un contenido graso de aproximadamente $10.72 \pm 0.41 \%$. Por lo cual se decidió incorporar aceite de girasol alto oleico (grasas saturadas=7.33 \%, MUFA n-9= $77.33 \%$ y PUFA= 6.33\%; Granix, Buenos Aires, Argentina) adquirido en un comercio 
local, y aceite refinado desodorizado de pescado (29.9\% n-3, $3.01 \%$ n-6; Omega Sur, Mar del Plata, Buenos Aires, Argentina) para obtener un producto con un contenido lipídico final de alrededor del 10\%. Las formulaciones también incluyeron fitoesteroles $90 \%$ (Advasterol 90, AOM SA, Buenos Aires, Argentina), agua destilada, ácido ascórbico grado alimentario, hexametafosfato de sodio (HMP) y $\mathrm{NaCl}$ de grado analítico. Como antioxidantes se emplearon extracto de semillas de uva (Leucoselect, Indena, Francia) o terbutil-hidroxi-quinona (BHTQ, Merck, Alemania). Como emulsificantes-ligantes se incorporaron dos concentrados de proteínas de suero lácteo: WPC80 (concentrado de proteínas de suero lácteo 80\%, Arla Food Ingredients S.A., Buenos Aires, Argentina) o WPC40 (concentrado de proteínas de suero lácteo $40 \%$, Milkaut S.A., Santa Fe, Argentina).

VII.2.2. Diseño Experimental A - Evaluación de la efectividad de un antioxidante natural en relación al uso de uno sintético aplicado en hamburguesas de pescado.

Se realizó un diseño factorial $(2 \times 4 \times 5)$, donde los factores considerados fueron la concentración de proteína de suero incorporada (en 2 niveles correspondientes a WPC40 y WPC80), el tipo y concentración de antioxidante utilizada (control sin antioxidante, extracto de semilla de uva en dos dosis diferentes y BHTQ) y el tiempo de almacenamiento congelado.

En esta etapa de la Tesis, se evaluó la posibilidad de sustituir el antioxidante sintético (BHTQ) por uno natural (extracto de semillas de uva). Como se explicó previamente, el antioxidante sintético es utilizado normalmente en la industria para prevenir la oxidación de los lípidos presentes en los alimentos durante su almacenamiento. Si bien es conocida su gran efectividad, también son considerados riesgosos para la salud de los consumidores (Giménez y col., 2011). El BHTQ se incorporó en una concentración de 100 ppm expresados en base al contenido de grasa del producto final, de esta manera se trabajó por debajo del límite permitido para este compuesto que es de 200 ppm (FSIS, 2007) y siguiendo las reglamentaciones vigente en Argentina establecidas en el Decreto 4238/68 de SENASA y en el CAA. En el Decreto 4238/68 se establece como límite para el uso de antioxidante sintético "hasta 200 ppm en su producto terminado". En el CAA se establece como dosis máxima permitida "hasta 100 ppm del antioxidante sintético utilizado solo o combinado con otros antioxidantes sintéticos sobre base grasa del producto final". En este trabajo se diseñaron formulaciones bajas en grasa, con $10 \%$ de lípidos en su composición cruda, por lo cual el BHTQ se incorporó en dosis de $0.001 \%$ en las correspondientes fórmulas (Tabla VII - 1). 
El extracto de semillas de uva fue evaluado previamente en el Capítulo V donde se observó buena actividad como antioxidante durante el almacenamiento congelado de desmenuzado de saraca. Por lo cual fue seleccionado como antioxidante natural para ser utilizado en las formulaciones de hamburguesas de saraca y evaluar su efectividad frente al antioxidante sintético utilizado usualmente en productos de la pesca. Se definieron dos dosis de trabajo para el extracto de uva, una fue de 700 ppm $(0.7 \mathrm{~g} / 100 \mathrm{~g})$, utilizando la misma dosis evaluada en los ensayos realizados en el desmenuzado de pescado y una segunda dosis de 1400 ppm $(0.14 \mathrm{~g} / 100 \mathrm{~g})$. Este aumento en la dosis del antioxidante natural se basó en la decisión de incorporar aceite de pescado en las formulaciones aprovechando la matriz del pescado como base. Los lípidos del aceite de pescado son más susceptibles a la oxidación que los lípidos presentes en la carne de pescado. Esta mayor susceptibilidad al deterioro se debe principalmente a los procesos de extracción y refinación, además de quedar más expuestos al oxígeno circundante en el alimento. La Tabla VII - 1 muestra la codificación usada para denominar las formulaciones y las combinaciones antioxidante-tipo de WPC usadas.

Tabla VII- 1: Formulaciones de hamburguesas de saraca (expresado en $\mathrm{g} / 100 \mathrm{~g}$ de producto)

\begin{tabular}{|c|c|c|c|c|c|}
\hline \multirow{2}{*}{ Nomenclatura } & \multicolumn{5}{|c|}{ Ingredientes } \\
\cline { 2 - 6 } & \multicolumn{2}{|c|}{ Antioxidante } & \multicolumn{3}{c|}{ WPC } \\
\cline { 2 - 6 } & Uva & BHTQ & 40 & 80 & \\
\hline Control WPC40 & ----- & ----- & 3 & ----- & 74.90 \\
\hline Control WPC80 & ----- & ----- & ----- & 3 & 74.90 \\
\hline BHTQ WPC40 & ----- & 0.001 & 3 & ----- & 74.89 \\
\hline BHTQ WPC80 & ----- & 0.001 & ----- & 3 & 74.89 \\
\hline UVA 700 WPC40 & 0.07 & ----- & 3 & ----- & 74.83 \\
\hline UVA 700 WPC80 & 0.07 & ----- & ---- & 3 & 74.83 \\
\hline UVA 1400 WPC40 & 0.14 & ----- & 3 & ----- & 74.76 \\
\hline UVA 1400 WPC80 & 0.14 & ----- & ----- & 3 & 74.76 \\
\hline
\end{tabular}

A su vez, en este ensayo se consideró como control formulaciones con agregado de WPC40 y WPC80 sin el agregado de compuestos antioxidantes. Para cada formulación se prepararon partidas de $1.25 \mathrm{~kg}$ de mezcla cruda, obteniéndose aproximadamente 25 hamburguesas de $50 \mathrm{~g}$ cada una. En todos los casos, cada $100 \mathrm{~g}$ de producto se incorporaron $16.5 \mathrm{~g}$ agua, $3 \mathrm{~g}$ aceite de girasol alto oleico, $0.5 \mathrm{~g}$ de 
aceite de pescado, $0.3 \mathrm{~g}$ hexametafosfato de $\mathrm{Na}, 0.7 \mathrm{~g} \mathrm{NaCl}, 0.3 \mathrm{~g}$ ácido ascórbico y $0.8 \mathrm{~g}$ de fitoesteroles.

\section{Elaboración de hamburguesas de saraca}

Las formulaciones se prepararon en una mezcladora industrial (Modelo B200 DT, Blakkeslee, EEUU). El proceso se realizó en 2 etapas, en la primera etapa se mezcló durante 1 minuto a velocidad 2 el pescado junto con todos los sólidos previamente mezclados (Tabla VII - 1): el cloruro de sodio, el hexametafosfato de sodio, el ácido ascórbico y el antioxidante correspondiente para cada formulación.

En una segunda etapa se incorporó el WPC correspondiente a cada formulación, previamente hidratado en agua durante 10 minutos y emulsionado con los fitoesteroles, los aceites (alto oleico y pescado) durante 30 segundos a velocidad 6 en un homogeneizador provisto de un rotor-estator (Omni-Mixer, Omnimixer International, EEUU). La incorporación de la emulsión a la carne de pescado se realizó lentamente durante 1 minuto y luego se completó el mezclado durante 1 minuto a la misma velocidad (Figura VII-1).

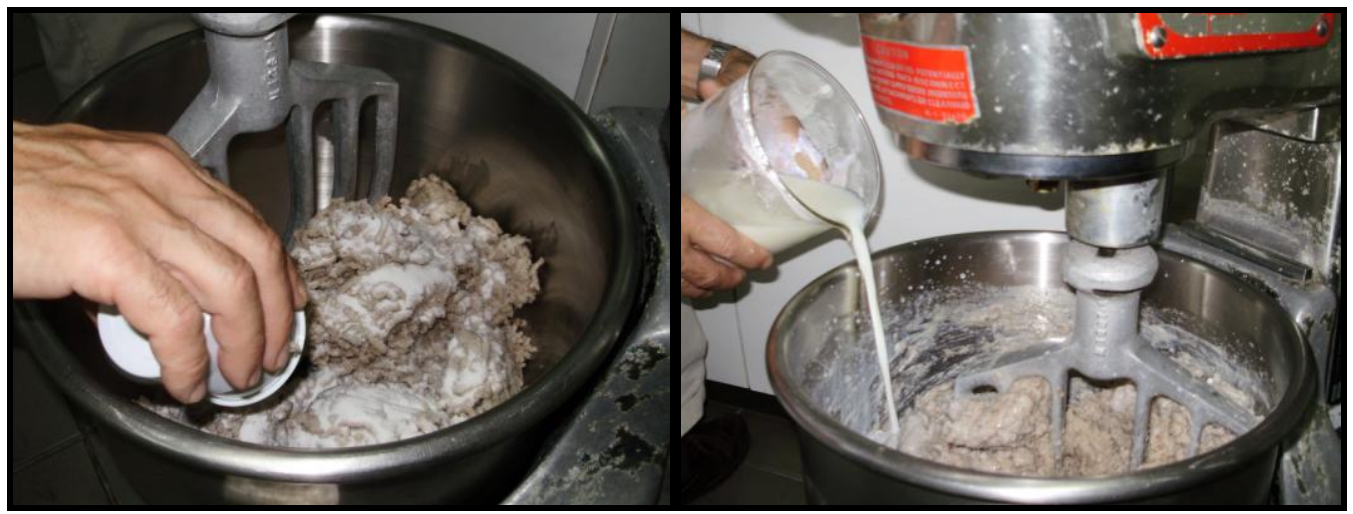

Figura VII- 1: Etapas de mezclado en el desarrollo de hamburguesas de saraca.

Izquierda: incorporación de sólidos. Derecha: incorporación de la emulsión

Las hamburguesas de saraca se moldearon en un equipo manual formador de hamburguesas adaptado con un cilindro de acrílico (Figura VII-2) especialmente diseñado para formar hamburguesas de $60 \mathrm{~mm}$ de diámetro, $20 \mathrm{~mm}$ de altura y de 50 $\pm 1 \mathrm{~g}$ de peso. Las muestras se congelaron a $-25^{\circ} \mathrm{C}$ en freezer durante $24 \mathrm{hs}$. Se acondicionaron congeladas en bolsas de baja permeabilidad al oxigeno (BB4L Cryovac, Sealed Air Co., Buenos Aires Argentina, $\mathrm{PO}_{2:} 35 \mathrm{~cm}^{3} \mathrm{~m}^{-2}$ día $^{-1}$ bar $^{-1}$ a $23^{\circ} \mathrm{C}$ ) en packs de dos unidades. Se almacenaron congeladas durante 6 meses a $-25^{\circ} \mathrm{C}$. Los análisis se realizaron cada 45 días a lo largo del almacenamiento. 

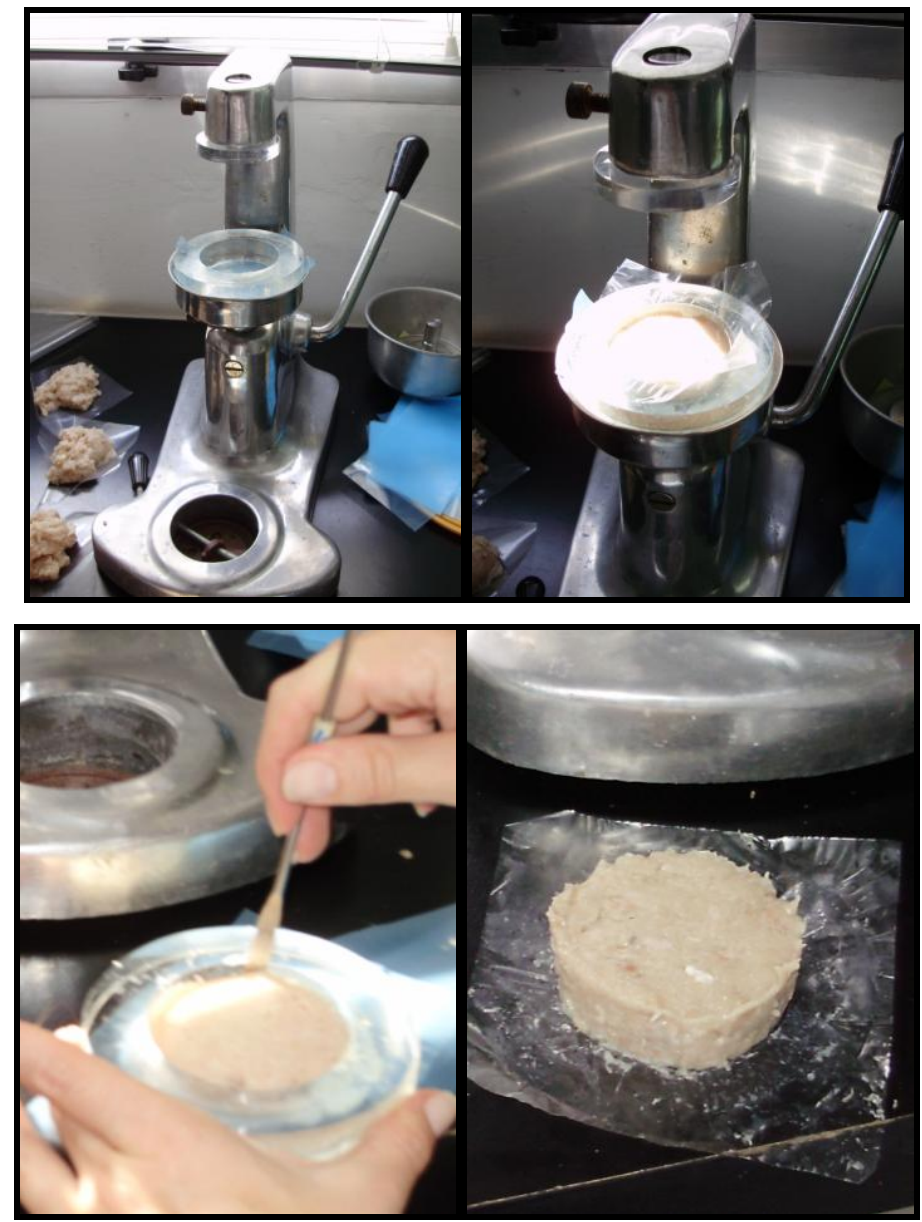

Figura VII- 2: Etapas del moldeado de hamburguesas.

\section{Oxidación lipídica}

La oxidación lipídica se determinó en las muestras crudas mediante el método del ácido tiobarbitúrico, explicado en la sección V.2.6. Los análisis se realizaron cada 45 días durante un período de 6 meses de almacenamiento congelado a $-25^{\circ} \mathrm{C}$. En cada determinación se utilizaron 3 hamburguesas, cada una fue picada y homogenizada congelada para evitar la oxidación y se determinó en cada una, por cuadruplicado, el número de TBARS.

VII.2.3.Diseño Experimental B. Estudio de los cambios en los parámetros de calidad de hamburguesas de saraca, crudos y cocidos, durante su almacenamiento a $-25^{\circ} \mathrm{C}$.

Se utilizó un diseño factorial $2 \times 2 \times 5$, considerando como factores a estudiar el tipo de antioxidante (extracto de semillas de uva o control), la concentración de WPC (40\% u 80\%), y los distintos tiempos de almacenamiento congelado. Dado los resultados obtenidos en el Capítulo V, cuando se trabajó sobre desmenuzado de saraca, se decidió incluir en el estudio únicamente la mayor concentración de extracto de uva ya 
que el material correspondiente a la captura de mayo no permitía incorporar más combinaciones a la experiencia. Se prepararon los conformados con las siguientes formulaciones estudiadas (Control WPC40, Control WPC80, UVA 1400 WPC40 y UVA 1400 WPC80) de acuerdo a lo descripto en VII.2.2. Se emplearon $5 \mathrm{~kg}$ para cada una de las formulaciones Control WPC40 y WPC80, utilizando aproximadamente 100 hamburguesas para cada formulación. Se elaboraron $7.5 \mathrm{~kg}$ de las formulaciones con antioxidante de UVA, obteniéndose 150 hamburguesas para cada una. En este grupo se prepararon 50 muestras más de cada formulación para utilizarlas en los ensayos sensoriales. El peso de cada hamburguesa fue de $50 \pm 1 \mathrm{~g}$.

Se utilizaron muestras cocidas y enfriadas para determinar la composición química, el rendimiento de la cocción, reducción de tamaño, retención de grasa y humedad, la jugosidad, perfil de textura y color. Los ensayos se realizaron periódicamente cada 45 días y durante los 6 meses del almacenamiento. También se utilizaron las dos formulaciones conteniendo extracto de semillas de uva para realizar un ensayo de aceptabilidad general y por atributos del producto por consumidores. Asimismo, se analizó la carga microbiana inicial y al final del almacenamiento congelado para lo cual se utilizaron algunas de las muestras crudas.

\section{Cocción de las hamburguesas}

Se realizó en una plancha calefactora de doble contacto (Modelo 3882, Oster, China) precalentada durante 30 minutos (Figura VII - 3). Este precalentamiento aseguró que siempre se alcanzaba la temperatura máxima $\left(210^{\circ} \mathrm{C}\right)$ en la superficie calefactora antes de colocar las hamburguesas. De esta forma no hubo diferencias en las historias térmicas durante la cocción de los distintos grupos.

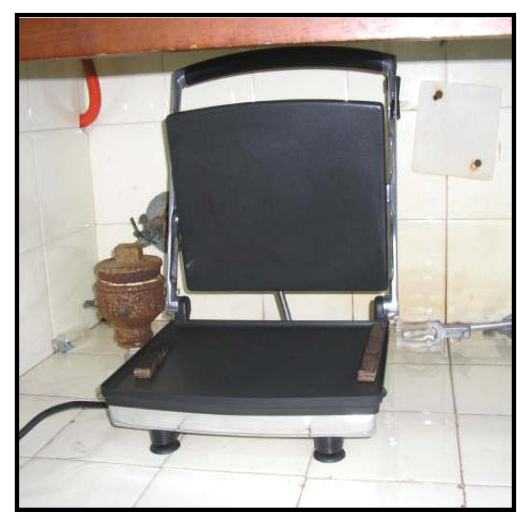

Figura VII- 3: Plancha calefactora de doble contacto utilizada para la cocción. 
El tiempo de cocción de las muestras congeladas se determinó como el tiempo necesario para que el centro de las mismas alcanzara los $68.3^{\circ} \mathrm{C}$ por 15 segundos, para asegurar la inocuidad microbiológica del producto. La temperatura en el interior de las hamburguesas se controló con una termocupla conectada a un registrador. La correcta cocción y un dorado externo parejo se logró cocinando 1.5 minutos de cada lado. Luego de la cocción, se dejaron enfriar las muestras sobre papel absorbente a temperatura ambiente dejando las muestras 6 minutos de cada lado, posteriormente se realizaron los análisis químicos y las determinaciones de las propiedades fisicoquímicas y funcionales que se detallan a continuación.

\section{Análisis de composición centesimal}

Se analizó la composición centesimal tanto de las hamburguesas de pescado crudas como cocidas. Se determinó el porcentaje de humedad, contenido de lípidos, cenizas y proteínas siguiendo lo explicado en III.2.6. Se realizaron seis replicados para cada formulación.

\section{Rendimiento de la cocción}

Se calculó como la diferencia del peso antes y después de la cocción. Se realizaron 9 replicados para cada tratamiento.

Rendimient $\mathrm{O}=\frac{(\text { masa cocida })}{(\text { masa cruda })} \times 100 \quad$ Ecuación VII- 1

\section{Reducción del tamaño}

Se determinó la relación entre el tamaño de la muestra cruda y cocida (ElMagoli, Laroiab y Hansed, 1996). Se realizaron 9 replicados para cada tratamiento.

$$
\text { Re ducción de tamaño }=\frac{(\text { altura crudo- altura cocido })+(\text { diam. c rudo }- \text { diam } \text { cocido })}{(\text { altura crudo }+ \text { diam. crudo })} \times 100
$$

Retención de humedad

Corresponde al porcentaje de agua en el producto cocido referido al contenido de humedad previo a la cocción. Se determinó para las diferentes formulaciones en los distintos tiempos de almacenamiento por duplicado.

$$
\text { Retención de humedad }=\frac{\% \text { agua }_{\text {cocida }}}{\% \text { agua }} \times \text { rendiamient } 0 \quad \text { Ecuación VII-3 }
$$




\section{Jugosidad por presión}

Se determinó como el porcentaje de líquido extraído por prensión de las muestras cocidas. Se comprimieron hamburguesas enteras en un equipo analizador de textura TA-xT2i (Texture Analyzer, Stable Micro Systems, UK) con sonda de $75 \mathrm{~mm}$ (Figura VII-4), colocadas entre dos láminas de papel de filtro $(10 \times 9 \mathrm{~cm})$ y cubiertas por 2 láminas de papel aluminio de las mismas dimensiones; las determinaciones se realizaron a temperatura ambiente. Se programó el texturómetro para realizar una presión de $100 \mathrm{~N}$ durante 2 minutos (Zorrilla, Rovedo y Singh, 2000). Las láminas de papel de filtro y de aluminio se pesaron antes y después de la prensión. La jugosidad se determinó por triplicado.

$$
\text { Jugosidad }=\frac{(\text { peso de papeles final peso de papeles inicial })}{(\text { peso del conformado cocido })} \times 100
$$

Ecuación VII- 3

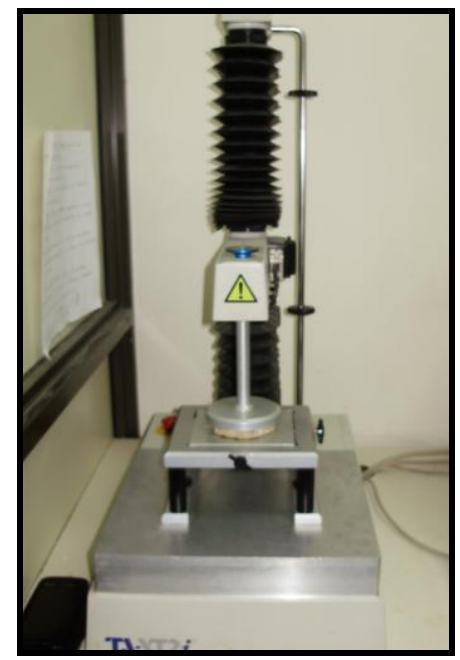

Figura VII- 4: Texturómetro TA-xT2i Texture Analyser

\section{Retención de lípidos}

Es la relación entre el porcentaje de lípidos del producto cocido referido al porcentaje lipídico del producto crudo. Se determinó por duplicado para las diferentes formulaciones y tiempos de almacenamiento.

$$
\text { Retención de lípidos }=\frac{\text { \%lípidos cocida }}{\text { \%lípidos cruda }} \times \text { rendimient o Ecuación VII- } 4
$$




\section{Perfil de ácidos grasos}

Se analizó el perfil de ácidos grasos de las muestras cocidas. La composición en ácidos grasos se obtuvo por cromatografía gaseosa acoplada a un detector masa. Se utilizó una columna capilar Omegawax 320 (30 m/0.32 mm id/ $0.25 \mu \mathrm{m})$ en un cromatógrafo Shimadsu 2010 con detector masa. El perfil de ácidos grasos de cada una de las muestras se obtuvo por comparación de los tiempos de retención relativos de cada uno de ellos respecto de estándares comerciales (Supelco 37 Component FAME Mix, Cat. No.18919-1 AMP, Sigma Aldrich) analizados previamente en la misma columna. La esterificación de los ácidos grasos se realizó según lo explicado en III.2.6.

Se determinó la calidad de los lípidos mediante el análisis del índice de aterogenicidad (IA) y el índice de trombogenicidad (IT). Estos índices se determinaron según lo explicado en I.2.6.

\section{Valor calórico total}

El valor calórico total se determinó como la suma del producto de los valores de Atwater correspondientes a las medias de proteína y lípidos multiplicados por los factores $4(\mathrm{kcal} / \mathrm{g})$ y $9(\mathrm{kcal} / \mathrm{g})$ respectivamente de cada formulación. Se calcularon las calorías totales (kcal) aportadas cada $100 \mathrm{~g}$ de producto cocido. El aporte calórico por hidratos de carbono al ser menor al $1 \%$ no fue considerado dentro del valor calórico total. También, se calcularon los aportes de ácidos grasos poli-insaturados cada $100 \mathrm{~g}$ de producto cocido y el aporte de fitoesteroles de la proporción que representan respecto a las ingestas diarias recomendadas.

\section{Textura}

El análisis del perfil de textura (TPA) se midió con un texturómetro TA-xT2i (Figura VII - 4) con una sonda de aluminio de $75 \mathrm{~mm}$ de diámetro (TA-30) acoplado con el programa Texture Expert. La determinación se realizó sobre hamburguesas enteras y cocidas. El equipo se programó para realizar dos ciclos de compresión del $30 \%$ de la altura del producto a velocidad de $1 \mathrm{~mm} / \mathrm{s}$, con un tiempo intermedio de 5 segundos. La determinación se realizó por cuadruplicado para cada tratamiento a lo largo del almacenamiento congelado.

A partir del gráfico (Figura VII - 5) se determinaron los siguientes parámetros:

- Dureza (fuerza máxima del primer ciclo de compresión, N).

- Adhesividad (área negativa del primer ciclo (área 3), representa el trabajo necesario para retirar la sonda de la muestra, J).

- Cohesividad (relación de área positivas del segundo ciclo (área 2) y área del primer ciclo (área 1 ), $\mathrm{J} / \mathrm{J}$ ). 
- Elasticidad (distancia hasta llegar al máximo de la segunda compresión (distancia 2) dividida la distancia hasta llegar al máximo de la primer compresión (distancia 1), $\mathrm{mm} / \mathrm{mm}$.

- Masticabilidad (dureza $x$ cohesividad $x$ elasticidad).

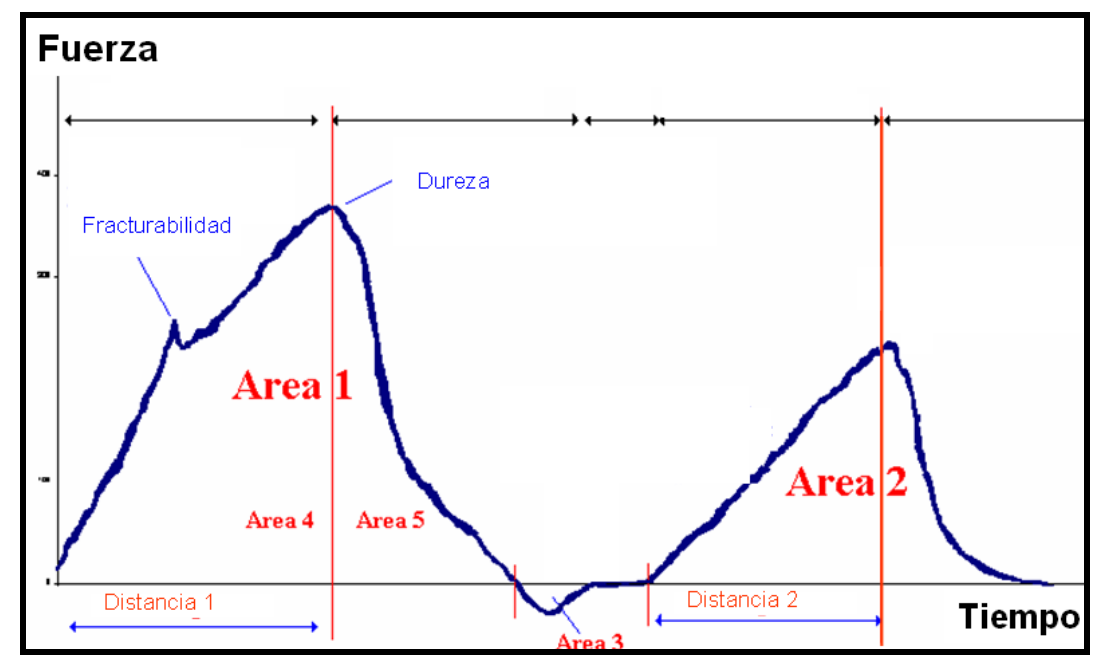

Figura VII- 5: Gráfico del Análisis de Perfil de Textura (TPA)

Color

Se describieron los parámetros $L^{*}, a^{*}$ y $b^{*}$ en la superficie de superficie de las hamburguesas y $\mathrm{W}$ (blancura), $\mathrm{a}^{*} \mathrm{y} \mathrm{b}^{*}$ en la parte interna de las mismas la medición se realizo según lo explicado en V.2.7. Se determinó por octuplicado para cada tratamiento. El parámetro W se determinó usando la formula descripta por Park (1994) la cual se relaciona con la blancura del producto (Ecuación VII-6).

$W=100-\left[\left(100-L^{*}\right)^{2}+a^{2}+b^{2}\right]^{1 / 2}$

Ecuación VII- 5

Recuentos microbianos

Se realizaron análisis microbiológicos al inicio y al finalizar el almacenamiento congelado en las formulaciones crudas. Se realizaron diluciones seriadas y se cuantificaron bacterias mesófilas totales y psicrófilas según lo explicado en la sección VI.2.3. A su vez, se analizaron la presencia de enterobacterias, hongos y levaduras.

Recuento de Enterobacteriaceae

Se utilizó el medio Agar Bilis Rojo Violeta Glucosa (ABRV)

$\begin{array}{lll}\text { Peptona de carne } & 7 & \mathrm{~g} / \mathrm{l} \\ \text { Extracto de levadura } & 3 & \mathrm{~g} / \mathrm{l}\end{array}$




$\begin{array}{lll}\text { CINa } & 5 & \mathrm{~g} / \mathrm{l} \\ \text { D-(+)-Glucosa } & 10 & \mathrm{~g} / \mathrm{l} \\ \text { Sales Biliares } & 1.5 & \mathrm{~g} / \mathrm{l} \\ \text { Rojo Neutro } & 0.03 & \mathrm{~g} / \mathrm{l} \\ \text { Cristal Violeta } & 0.002 & \mathrm{~g} / \mathrm{l} \\ \text { Agar } & 13 & \mathrm{~g} / \mathrm{l} \\ \mathrm{pH} & 7.3 \pm 0.1 \mathrm{~g} / \mathrm{l}\end{array}$

El medio se esteriliza a vapor fluente (B.M) media hora. La incubación se realizó a $37^{\circ} \mathrm{C}$, durante 48 hs.

Recuento de Hongos y Levaduras

Se determinó utilizando el medio Agar Cloranfenicol, Extracto de levadura, Glucosa (YGC)

$\begin{array}{lll}\text { Extracto de levadura } & 5 & \mathrm{~g} / \mathrm{l} \\ \text { Glucosa } & 20 & \mathrm{~g} / \mathrm{l} \\ \text { Agar } & 14.9 & \mathrm{~g} / \mathrm{l} \\ \text { Cloranfenicol } & 0.1 & \mathrm{~g} / \mathrm{l}\end{array}$

Autoclavar a $121^{\circ} \mathrm{C}$ durante 15 minutos. La incubación se realizo a $25-30^{\circ} \mathrm{C}$ durante 5 días.

Todas las determinaciones microbiológicas se hicieron por duplicado de dos hamburguesas crudas y los resultados obtenidos de los diferentes medios fueron expresados como log UFC/g.

\section{Ensayo de aceptabilidad por consumidores}

Se evaluó la aceptabilidad por consumidores de las hamburguesas de saraca para las formulaciones UVA1400 WPC40 y UVA1400 WPC80. Para el ensayo se utilizó una escala hedónica de $10 \mathrm{~cm}$ (donde el extremo izquierdo indica me disgusta mucho y el extremo derecho indica me gusta mucho). En dicha recta el consumidor marcó con una línea transversal el puntaje considerado para cada atributo según su grado de satisfacción. El análisis de los datos se realizó midiendo la distancia en centímetros desde el extremo me disgusta mucho hasta la marca realizada para cada atributo (Figura VII-6). El ensayo se llevó a cabo en el laboratorio de Tecnología de los Productos Pesqueros del Instituto Nacional de Investigación y Desarrollo Pesquero (INIDEP). Se convocó a todo el personal científico, técnico y administrativo del INIDEP a participar. Se realizó durante 3 días consecutivos en el horario de la mañana entre 
10:45 y 12:00 horas. Se trabajó con un amplio rango de edades, abarcando jóvenes adultos a adultos (entre 25-60) sin distinción de sexo. Las evaluaciones se realizaron en grupos de 6 consumidores por vez, sobre un total de 40 personas. Como requisito para participar se les solicitó que dispusieran de 15 minutos. Se les explicó la modalidad del ensayo y su importancia para evitar que realizaran comentarios entre los participantes. Se tomó requerimiento excluyente que respondieran afirmativo a las siguientes preguntas:

¿Se considera consumidor frecuente de pescado?

¿Consume al menos una vez por semana algún producto pesquero?

¿Consume hamburguesas de pescado tradicionales (empanadas y prefritas)?

\section{ACEPTABILIDAD DE HAMBURGUESAS DE PESCADO SIN COBERTURA}

Consumidor $\mathrm{N}^{0}$

Sexo

Edad:

Fecha:

Utilizando la siguiente escala, por favor evalúe la aceptabilidad total y luego la de cada atributo siguiendo el orden presentado. Comience por la muestra 467 y continue con la 813.

Marque con una línea transversal donde considere su puntuación para cada atributo.

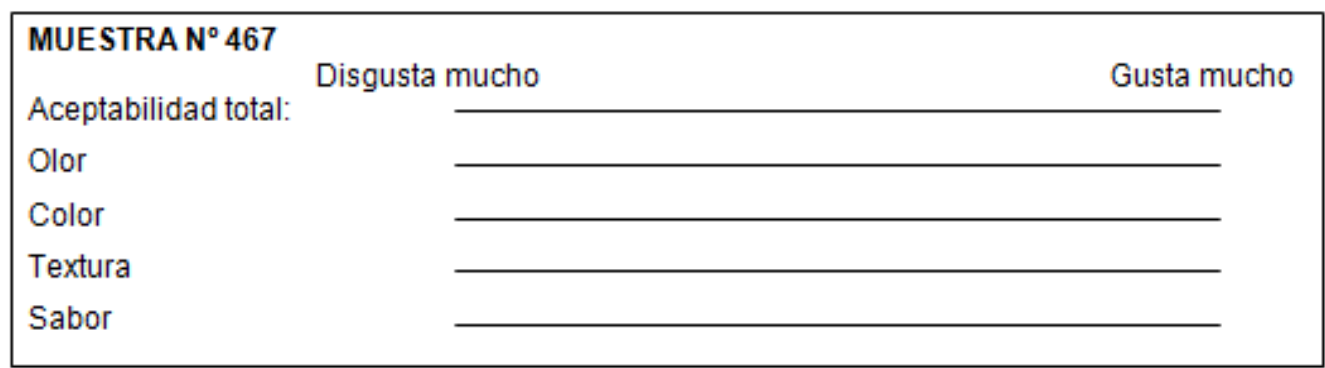

\begin{tabular}{|lll|}
\hline MUESTRA N ${ }^{\circ} \mathbf{8 1 3}$ & Disgusta mucho & Gusta mucho \\
Aceptabilidad total: & \\
Olor & \\
Color & \\
Textura & \\
Sabor & \\
\hline
\end{tabular}

Figura VII- 6: Ficha sensorial para el ensayo de aceptabilidad global y por atributos por consumidores

A cada grupo de consumidores se les explicó la metodología de trabajo. Se les solicitó que evaluaran la aceptación general, olor, color, textura y sabor en el orden presentado en la planilla (Figura VII - 6). A cada participante se le entregó una copia 
de la planilla, un vaso con agua mineral a temperatura ambiente y una galletita de agua sin sal para neutralizar el sabor entre muestra y muestra. Inmediatamente se le sirvió una porción caliente de cada formulación cocida y codificada con un número de 3 dígitos elegido al azar.

Análisis estadístico de los resultados

El análisis de los resultados se efectuó según lo explicado en III.4.6.

\section{VII.3.RESULTADOS Y DISCUSIÓN}

VII.3.1. Caracterización de la carne de saraca como materia prima

En las Tabla VII - 2 se presentan los parámetros evaluados para caracterizar la materia prima del desmenuzado de saraca de ejemplares capturados en mayo. Se observó que el contenido de lípidos totales fue $10.72 \pm 0.41 \%$, este valor es menor al observado en el Capítulo III cuando se evaluó el ciclo biológico, ya que el valor de lípidos observado en el mes de mayo durante el ciclo biológico del año 2009 fue de $17.2 \pm 4.01 \%$.

La diferencia lipídica entre los ejemplares capturados, en la misma fecha, en los distintos años, se debe a que las muestras analizadas en el Capítulo III se cuereaban a mano cuidando de mantener el "espejo de plata" donde se ubica la mayor cantidad de lípidos subcutáneos (Figura VII - 7), mientras que en este ensayo se cuereó con cuchillo donde se retiró una fina capa de músculo, el tejido conectivo correspondiente al espejo de plata y por lo tanto se eliminó una buena parte de la grasa subcutánea ubicada entre la piel y el filete.

Tabla VII- 2: Composición proximal del desmenuzado de saraca utilizado como materia prima para el desarrollo de hamburguesas.

$\begin{array}{ccc}\text { Variable } & \text { N } & \text { Media } \pm S D(g) \\ \text { Lípidos } & 3 & 10.72 \pm 0.41 \\ \text { Proteína } & 3 & 17.48 \pm 0.06 \\ \text { Humedad } & 3 & 69.70 \pm 0.72 \\ \text { Ceniza } & 3 & 1.33 \pm 0.02 \\ \text { *Valores promedio } \pm \text { desviación standard }(\mathrm{n}=3)\end{array}$

En relación a los demás parámetros no se observaron diferencias significativas con los resultados observados en el Capítulo III, donde los valores fueron para humedad: $66.32 \pm 3.47 \%$, proteína: $17.2 \pm 0.95 \%$ y cenizas: $1.29 \pm 0.11 \%$. 
Los resultados obtenidos del análisis de composición proximal de los conformados crudos y cocidos sin almacenamiento se presentan en la Tabla VII - 3. Las formulaciones crudas mostraron mínimas variaciones en las composiciones y en pocos casos con diferencias significativas, ya que las proporciones de los ingredientes principales no variaron y el desmenuzado se preparó a partir de un "pool" de pescado. La composición proximal de los productos crudos no varió con la formulación, presentando valores medios de $72.22 \pm 0.95 \%$ humedad, $16.48 \pm 0.91 \%$ proteína, $9.48 \pm 0.71 \%$ lípidos y $1.95 \pm 0.11 \%$ cenizas, mientras que para los cocidos fue menor la humedad $(63.90 \pm 1.54 \%)$ y mayor el contenido en proteínas $(21.58 \pm 0.84$ $\%)$, lípidos (11.98 $\pm 0.80 \%)$ y cenizas $(2.20 \pm 0.10 \%)$. El contenido de hidratos de carbono no se consideró en este trabajo ya que la presencia fue mínima, menor al $0.8 \%$.

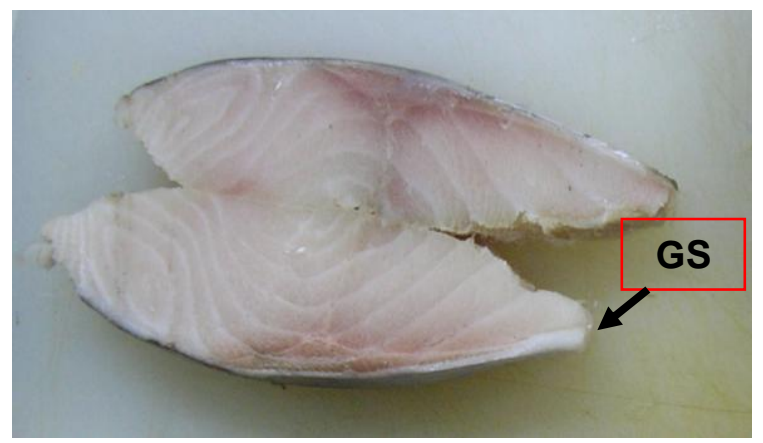

Figura VII- 7: Corte transversal de filete de saraca con grasa subcutánea (GS) entre músculo y espejo de plata.

En la Tabla VII - 3 se puede observar que la cocción redujo significativamente $(P<0.05)$ el contenido de humedad de las hamburguesas; sin embargo no se observaron diferencias significativas del mismo entre las cuatro formulaciones, tanto crudas como cocidas.

Con respecto al contenido de proteínas, lípidos y cenizas, si bien al analizarlos en base húmeda surgen diferencias entre formulaciones cocidas, al analizar la composición en base seca el contenido proteico dependió exclusivamente del tipo de WPC incorporado: para WPC40 (57.68 $\pm 0.80 \%$ bs) y para WPC80 (61.56 $\pm 1.2 \%$ bs $)$.

El contenido de lípidos aumentó por la cocción en el análisis en base húmeda, mientras que esta diferencia, explicado por el menor contenido de humedad de las hamburguesas de saraca cocidas, mientras que en base seca no se observaron diferencias significativas debido a la cocción, es decir, en la matriz seca se mantuvo la relación proteína/lípidos. Del análisis estadístico en el contenido de lípidos entre las muestras cocidas no se encontraron diferencias significativas debidas a ningún factor. 
Tabla VII - 3: Valores medios de la composición proximal de las formulaciones de conformados de saraca, crudos y cocidos, al inicio del almacenamiento (\% g/100g de producto)

\begin{tabular}{|c|c|c|c|c|c|}
\hline & Formulación & Humedad (\%) & Proteínas (\%) & Lípidos (\%) & Ceniza (\%) \\
\hline \multirow{4}{*}{$\frac{\pi}{0}$} & $\begin{array}{l}\text { Control } \\
\text { WPC40 }\end{array}$ & $73.00 \pm 0.67^{a}$ & $16.08 \pm 0.65^{a}$ & $8.62 \pm 0.33^{a}$ & $2.00 \pm 0.15^{\mathrm{abc}}$ \\
\hline & $\begin{array}{l}\text { Control } \\
\text { WPC80 }\end{array}$ & $72.23 \pm 1.12^{a}$ & $17.08 \pm 0.36^{a}$ & $9.63 \pm 0.86^{\mathrm{ab}}$ & $1.90 \pm 0.04^{\mathrm{ab}}$ \\
\hline & $\begin{array}{l}\text { UVA1400 } \\
\text { WPC40 }\end{array}$ & $71.81 \pm 1.12^{a}$ & $15.73 \pm 0.83^{\mathrm{a}}$ & $9.98 \pm 0.37^{b}$ & $2.03 \pm 0.05^{\mathrm{abc}}$ \\
\hline & $\begin{array}{l}\text { UVA1400 } \\
\text { WPC80 }\end{array}$ & $71.85 \pm 0.33^{a}$ & $17.02 \pm 0.96^{\mathrm{a}}$ & $9.70 \pm 0.23^{\mathrm{ab}}$ & $1.86 \pm 0.03^{\mathrm{a}}$ \\
\hline \multirow{4}{*}{$\begin{array}{l}\frac{\pi}{0} \\
0 \\
0\end{array}$} & $\begin{array}{l}\text { Control } \\
\text { WPC40 }\end{array}$ & $65.04 \pm 0.27^{b}$ & $20.35 \pm 0.04^{b}$ & $11.57 \pm 0.02^{c}$ & $2.24 \pm 0.02^{\mathrm{de}}$ \\
\hline & $\begin{array}{l}\text { Control } \\
\text { WPC80 }\end{array}$ & $64.91 \pm 0.03^{b}$ & $21.83 \pm 0.27^{b c}$ & $11.43 \pm 0.09^{c}$ & $2.20 \pm 0.00^{\text {cde }}$ \\
\hline & $\begin{array}{l}\text { UVA1400 } \\
\text { WPC40 }\end{array}$ & $61.48 \pm 0.10^{b}$ & $21.93 \pm 0.02^{b c}$ & $13.19 \pm 0.66^{\mathrm{d}}$ & $2.29 \pm 0.05^{\mathrm{e}}$ \\
\hline & $\begin{array}{l}\text { UVA1400 } \\
\text { WPC80 }\end{array}$ & $64.14 \pm 0.13^{b}$ & $22.20 \pm 0.79^{c}$ & $11.74 \pm 0.04^{c}$ & $2.07 \pm 0.12^{b c d}$ \\
\hline
\end{tabular}

*Valores promedio \pm desviación standard $(\mathrm{n}=6)$

** Letras diferentes dentro de la misma columna indican que los valores medios difieren significativamente $(P<0.05)$

En relación a las cenizas se observó un efecto significativo debido al tratamiento térmico entre las formulaciones crudas y cocidas en base seca. Las muestras crudas presentaron mayor contenido de ceniza (7.02 $0.4 \% \mathrm{bs})$ que las muestras cocidas $(6.10 \pm 0.31 \% b s)$ esta reducción se podría explicar por una pérdida de minerales arrastrados por el líquido perdido durante la cocción. Entre las formulaciones cocidas en base seca se observó un efecto debido a los factores principales WPC y antioxidante. Se observó que las formulaciones con WPC40 presentaron valores superiores en el contenido de ceniza que las muestras con WPC80 (7.03 $\pm 0.59 \%$ bs y $6.55 \pm 0.40 \%$ bs, respectivamente) y con respecto al uso de antioxidante se observó que las muestras control presentaron valores mayores respecto de las muestras con extracto de uva $(6.73 \pm 0.16 \%$ bs y $6.39 \pm 0.22 \% b s)$. 
VII.3.2. Diseño Experimental A - Evaluación de la efectividad de un antioxidante natural en relación al uso de uno sintético aplicado en hamburguesas de pescado.

En esta primera etapa del análisis de las formulaciones de hamburguesas de saraca, se evaluó la efectividad de un antioxidante natural aplicado en dos dosis frente al antioxidante sintético utilizado habitualmente en productos pequeros. Para ello se evaluó el desarrollo de los compuestos secundarios, producto de la oxidación lipídica durante el almacenamiento congelado. Se analizaron las diferentes formulaciones de hamburguesas, incluidas las formulaciones sin el agregado de antioxidantes para evaluar el efecto antioxidante de los sueros de leche incorporados.

Al inicio del almacenamiento congelado se encontraron diferencias significativas entre las formulaciones (Tabla VII - 4). Esto se puede relaciona con la velocidad de deterioro que presentan los lípidos de la materia prima y con la efectividad de los diferentes antioxidantes aplicados en las primeras etapas de procesamiento para demorar los procesos relacionados con la oxidación. Valores y comportamientos similares en TBARS fueron observados por Tokur y col. (2006) en bastones de carpa almacenados congelados durante 6 meses.

Tabla VII- 4: Valores de TBARS, expresados como mg MDA/kg, al inicio del almacenamiento congelado ( 0 días) de las diferentes formulaciones de hamburguesas de saraca.

\begin{tabular}{|l|l|l|}
\hline \multicolumn{1}{|c|}{ WPC } & Antioxidante & Medias \pm S.D. \\
\hline WPC 40 & BHTQ & $0.13 \pm 0.02^{\mathrm{a}}$ \\
\hline WPC 40 & UVA 1400 & $0.16 \pm 0.02^{\mathrm{a} b}$ \\
\hline WPC 80 & BHTQ & $0.21 \pm 0.04^{\mathrm{b}}$ \\
\hline WPC 80 & UVA 1400 & $0.25 \pm 0.03^{\mathrm{cd}}$ \\
\hline WPC 40 & CONTROL & $0.27 \pm 0.02^{\mathrm{cd}}$ \\
\hline WPC 40 & UVA 700 & $0.32 \pm 0.05^{\mathrm{de}}$ \\
\hline WPC 80 & UVA 700 & $0.36 \pm 0.02^{\mathrm{e}}$ \\
\hline WPC 80 & CONTROL & $0.38 \pm 0.03^{\mathrm{e}}$ \\
\hline
\end{tabular}

* Los resultados se muestran como medias \pm desviación standard $(n=12)$. Letras diferentes indican diferencias significativas entre las medias $(P<0.05)$.

Asimismo, se observó una interacción significativa entre los antioxidantes ensayados, el tipo de WPC utilizado y el tiempo de almacenamiento (Figura VII - 8). Las muestras que contenían extracto de UVA 1400ppm y BHTQ con WPC40 
presentaron los menores valores de TBARS, desde el inicio y a lo largo del almacenamiento. En la formulación BHTQ WPC40 se observaron valores de $0.13 \pm$ $0.02 \mathrm{mg} \mathrm{MDA} / \mathrm{kg}$ al inicio del almacenamiento y de $0.20 \pm 0.01 \mathrm{mg} \mathrm{MDA} / \mathrm{kg}$ al sexto mes. Mientras que la formulación con UVA1400 WPC40 presentó valores de $0.16 \pm$ $0.02 \mathrm{mg} \mathrm{MDA} / \mathrm{kg}$ y $0.22 \pm 0.01 \mathrm{mg} \mathrm{MDA} / \mathrm{kg}$ al inicio y al final del almacenamiento, respectivamente.

Las muestras control (sin antioxidantes agregados) para ambos WPC presentaron una oxidación mayor que las muestras con antioxidante desde el comienzo del almacenamiento (WPC40 $=0.27 \pm 0.02 \mathrm{mg} \mathrm{MDA} / \mathrm{kg}$ y WPC80 $=0.38 \pm$ $0.03 \mathrm{mg} \mathrm{MDA} / \mathrm{kg}$ ), presentaron un aumento continuo y significativo a lo largo del tiempo de almacenamiento, alcanzando un valor máximo al sexto mes (WPC40 =0.35 $\pm 0.11 \mathrm{mg} \mathrm{MDA} / \mathrm{kg}$ y WPC80=0.43 $\pm 0.03 \mathrm{mg} \mathrm{MDA} / \mathrm{kg}$ ). Sin embargo, la Figura VII - 8 parece indicar que las formulaciones control, al llegar al sexto mes, aún no alcanzaron el nivel máximo de oxidación. Las muestras con antioxidante UVA700 y ambos WPC presentaron, al igual que las formulaciones control, niveles de oxidación mayores con respecto al uso de los antioxidantes UVA1400 y BHTQ.

Las formulaciones con BHTQ o antioxidante de UVA para ambos WPC se observó un comportamiento creciente en el número de TBARS, alcanzando un máximo a los 45 días con un posterior descenso. Este comportamiento se relaciona con la formación de los productos secundarios propios del proceso de oxidación. Este comportamiento fue observado por Ninan, Bindu y Joseph (2010), quienes trabajando en albóndigas de tilapia almacenadas congeladas a $-20^{\circ} \mathrm{C}$ durante 21 semanas, observaron un pico máximo a la novena semana de almacenamiento y luego un descenso; resultados similares fueron informados para hamburguesas de tilapia y bastones de carpa por Tokur y col. (2004 y 2006). Ninan, Bindu y Joseph (2010) explican el comportamiento creciente y luego decreciente en los valores de oxidación de los lípidos en productos pesqueros como una reducción debida a la interacción entre los productos de la hidrolisis de lípidos, el malonaldehido/aldehídos y las proteínas.

Las hamburguesas de saraca además de contener antioxidantes fueron formuladas con WPC, el que, además de poseer actividad emulsificante presenta actividad antioxidante ( $\mathrm{Hu}$, McClements y Decker, 2003). Como puede verse en la Figura VII- 8, las formulaciones con WPC40 presentaron valores menores de TBARS que las que contenían WPC80. 


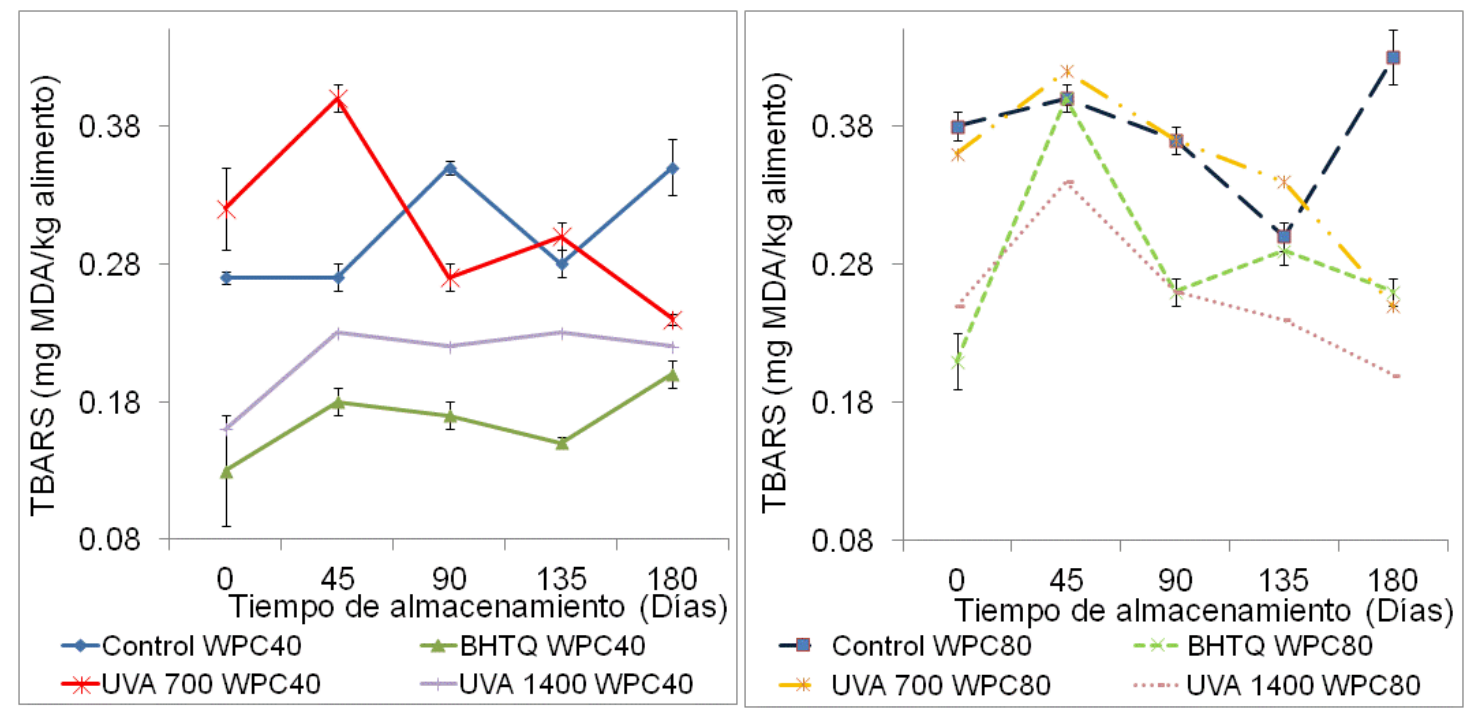

Figura VII- 8: TBARS de las formulaciones ensayadas durante 6 meses de almacenamiento congelado a $-25^{\circ} \mathrm{C}$. Muestras con (UVA 700; UVA1400; BHTQ) y sin (Control) el agregado de antioxidante y con WPC 40 (Izquierda) o WPC 80 (Derecha). Los resultados se expresaron como número de TBA = mg malonaldehído (MDA)/kg de producto \pm error standard de la media, $n=12$ ).

$\mathrm{Hu}$, McClements y Decker (2003) evaluaron la estabilidad antioxidante de proteínas de suero utilizado como emulsificante de aceite de salmón y agua. Observaron que el suero de leche dulce (SW) con 12.1\% de proteínas presentó una capacidad antioxidante mayor que el hidrolizado de suero de leche (WPI, 97.6\% proteína); este fenómeno lo atribuyeron a que el SW contiene numerosos compuestos que no se encuentran en el WPI debido a los tratamientos para su obtención, como por ejemplo la purificación. Algunos compuestos que se encuentran en el SW son minerales, citrato, fosfato, lactosa y péptidos de bajo peso molecular, compuestos que colaboran en la estabilidad frente a la oxidación de los lípidos. El citrato, el fosfato y los fosfopéptidos de caseína son conocidos como quelantes de hierro y potenciales inhibidores de la oxidación lipídica. Asimismo, estos autores propusieron que otro factor responsable en las diferencias en la estabilidad frente a la oxidación podría estar dada en la diferente composición de los aminoácidos presentes en el suero de leche. Dependiendo del procedimiento de obtención, los WPC más concentrados requieren de más tratamientos (térmicos y de purificación) que actúan sobre las proteínas cambiando su estructura, lo que conlleva a una menor exposición de aminoácidos libres con capacidad para actuar sobre los radicales libres, inhibiendo la oxidación, como es el caso de los aminoácidos azufrados. 
Peña-Ramos y Xiong (2003) en sus estudios observaron que los hidrolizados de proteína de suero de leche pueden inhibir la formación de TBARS formando un sistema complejo que cataliza al hierro en un $65 \%$ pero esta propiedad depende de los tratamientos para la obtención del suero de leche. Cuanto mayor es el procesamiento a altas temperaturas (durante la evaporación y secados) para la obtención de los concentrados de suero de leche, mayor desnaturalización irreversible se produce en las proteínas que lo componen y se refleja directamente en sus propiedades funcionales (de Wit, 1998). Estas observaciones se podrían relacionar con los datos observados en esta Tesis, donde el WPC40 al ser obtenido con menos procesamiento que el WPC80 más purificado, presentaría mayor poder antioxidante.

En el Capítulo $V$ se evaluaron los niveles de oxidación durante el almacenamiento congelado de desmenuzado de saraca con diferentes antioxidantes. Estos valores fueron superiores a los observados en esta experiencia para todas las formulaciones; las muestras de desmenuzado de ejemplares capturados en julio presentaron valores menores de TBARS que los desmenuzados de diciembre. En el Capítulo $\mathrm{V}$ también se observó en el desmenuzado de julio, una efectividad similar entre los antioxidantes BHTQ y UVA. Presentaron valores iniciales de $0.42 \pm 0.06 \mathrm{mg}$ $\mathrm{MDA} / \mathrm{kg}$ y $0.42 \pm 0.09 \mathrm{mg} \mathrm{MDA} / \mathrm{kg}$ respectivamente. Estos valores fueron mayores a los valores iniciales observados en las hamburguesas de pescado. Esto se puede explicar por el agregado en las formulaciones de compuestos como el ácido ascórbico y el hexametafosfato de sodio que actúan como secuestrantes de metales, impidiendo que actúen en la etapa de iniciación de la oxidación de los lípidos. Además de la actividad de los concentrados de suero de leche descripta recientemente actuando como secuestrantes y evitando la oxidación.

En este estudio la capacidad antioxidante del extracto de uva aplicado en una concentración de 0.14g/100g (UVA 1400) fue tan efectiva como el antioxidante sintético BHTQ para evitar la oxidación durante el almacenamiento congelado de las hamburguesas de saraca. Estos resultados permiten inferir que los compuestos fenólicos naturales son efectivos para prevenir la rancidez de los lípidos presentes en sistemas alimenticios complejos como aceites de pescado (Medina y col, 1999) y en desmenuzado de pescado (Ikawa, 1998; Alghazeer, Saeed y Howell, 2008). La efectividad de los compuestos fenólicos naturales se relaciona con el contenido de polifenoles presentes en el extracto natural. La estructura de los grupos $\mathrm{OH}$ presentes en las catequinas tienen la capacidad de actuar sobre los radicales libres generados durante la peroxidación de los lípidos y también tienen la capacidad de quelar los iones metálicos. En comparación con $\alpha$-tocoferol, las catequinas fueron reportados 
como antioxidantes más efectivos utilizados en alimentos a base de carnes cocidas o productos con pescado (Alghazeer, Saeed y Howell, 2008)

La dosis UVA1400 utilizada, presentaba el doble de catequinas (200ppm de catequinas) respecto a la dosis UVA700 (100ppm de catequinas), y fue la más efectiva. El efecto de los antioxidantes dependen de varios factores como la habilidad para mezclarse en la matriz cárnica, la actividad como antioxidante en diferentes sistemas con lípidos y la estabilidad a lo largo de los diferentes procesamientos (Alghazeer, Saeed y Howell, 2008). Tang y col. (2001) observaron que la utilización de 300ppm de catequinas de té fueron efectivas para evitar la oxidación de lípidos en carnes rojas cocidas y de pollo.

Es importante destacar que durante el almacenamiento congelado las distintas formulaciones presentaron siempre valores de TBARS menores a $0.5 \mathrm{mg} \mathrm{MDA} / \mathrm{kg}$ de alimento, siendo menor al límite establecido por Connell (1995) de 2 mg MDA/kg de músculo de pescado, valor que se correlaciona con el olor y sabor a rancio.

VII.3.3. Diseño experimental B. Estudio de los cambios en los parámetros de calidad de conformados de saraca, crudas y cocidas, durante su almacenamiento a $-25^{\circ} \mathrm{C}$.

El objetivo principal en esta etapa fue evaluar los parámetros de calidad en las formulaciones crudas y cocidas, por lo que se decidió comparar la formulación UVA1400 WPC40 con su homóloga con WPC80. La decisión de utilizar y comparar el uso del WPC80 y WPC40 se debe principalmente a que sólo el WPC80 es ampliamente utilizado en el desarrollo de productos cárnicos. Varios autores recomiendan su uso en productos cárnicos por presentar buena capacidad para emulsificar y retener la jugosidad del producto luego de la cocción (Pérez, Wargon y Pilosof, 2006). Mientras que la proteína de suero de leche con concentración de 35\% de proteína en el total de sólidos se suele utilizar como reemplazo de la crema de leche en productos alimenticios para humanos o alimentos para animales de bajo costo. El suero de leche con gran contenido de proteínas (y los aislados de proteína de suero) se utiliza exclusivamente para productos del tipo de panadería y productos cárnicos (de Wit, 1998; Tunik, 2008). Si bien existen muchos trabajos donde se analiza el efecto de la utilización de los WPC, no se encontraron trabajos donde se comparara el efecto del agregado de uno frente al otro. Por lo cual resulta deseable comparar los parámetros de calidad del producto utilizando ambos WPC ya que el WPC $40 \%$ se produce en el país mientras que el WPC $80 \%$ se importa a alto costo. 
A partir de lo explicado se decidió utilizar las formulaciones UVA1400 WPC40 y UVA1400 WPC80 y a modo control se analizaron las muestras sin antioxidantes también para los diferentes sueros de leche (Control WPC40 y Control WPC80).

\section{Rendimiento de la cocción}

Se determinó el rendimiento en cocción para las diferentes formulaciones de conformados durante el almacenamiento congelado a $-25^{\circ} \mathrm{C}$ (Tabla VII - 5). Se analizaron 9 muestras de cada formulación cada 45 días hasta alcanzar el sexto mes de almacenamiento. El rendimiento de los conformados, presentó valores elevados en todas las formulaciones a lo largo del almacenamiento (entre $65.46 \pm 3.17 \%$ y $75.44 \pm$ $6.67 \%$ ). Sólo tuvieron un efecto significativo el tipo de WPC utilizado y el tiempo de almacenamiento, siendo los resultados independientes de la adición o no del antioxidante de UVA1400.

Tabla VII- 2: Rendimientos en cocción porcentuales (\%) en función del tiempo de almacenamiento a $-25^{\circ} \mathrm{C}$ de diferentes formulaciones de conformados de saraca. ${ }^{*}$

\begin{tabular}{|rcccl|}
\hline & & \multicolumn{3}{c|}{ Formulaciones } \\
Tiempo & Control WPC40 & Control WPC80 & UVA1400 WPC40 & UVA1400 WPC80 \\
\hline $\mathbf{0}$ & $75.44 \pm 6.67^{\mathrm{e}}$ & $73.48 \pm 2.42^{\text {bcde }}$ & $75.08 \pm 6.01^{\text {de }}$ & $74.85 \pm 2.78^{\text {de }}$ \\
\hline $\mathbf{4 5}$ & $69.74 \pm 2.69^{\text {abcde }}$ & $73.75 \pm 6.82^{\text {cde }}$ & $68.35 \pm 3.25^{\text {abcd }}$ & $72.86 \pm 6.34^{\text {bcde }}$ \\
\hline $\mathbf{9 0}$ & $72.04 \pm 6.25^{\text {abcde }}$ & $71.82 \pm 2.54^{\text {abcde }}$ & $66.59 \pm 2.25^{\text {ab }}$ & $72.67 \pm 2.40^{\text {bcde }}$ \\
\hline 135 & $69.50 \pm 2.63^{\text {abcde }}$ & $69.55 \pm 1.94^{\text {abcde }}$ & $66.86 \pm 1.77^{\text {abc }}$ & $69.61 \pm 3.57^{\text {adcde }}$ \\
\hline 180 & $65.46 \pm 3.17^{\text {a }}$ & $70.56 \pm 2.13^{\text {abcde }}$ & $67.56 \pm 3.38^{\text {abc }}$ & $69.91 \pm 3.13^{\text {abcde }}$ \\
\hline
\end{tabular}

*Valores promedio \pm desviación standard $(n=6)$

** Letras diferentes entre los valores medios indican diferencias significativas $(P<0.05)$

Al inicio del almacenamiento no se observaron diferencias significativas en el rendimiento de las distintas formulaciones, y correspondió a un rango entre $73.48 \pm$ $2.42 \%$ y $75.44 \pm 6.67 \%$. Por otro lado, al avanzar el tiempo de almacenamiento congelado se observó una reducción en el rendimiento del producto cocido. Valores similares al inicio del almacenamiento fueron presentados por Sánchez-Alonso, HajiMaleki y Borderías (2007) en conformados de caballa donde evaluaron el efecto del agregado de fibra vegetal en productos pesqueros (74.48 y $76.19 \%$ para muestras control y con el agregado de fibra vegetal respectivamente). Este comportamiento también fue observado en medallones de carne con el agregado de WPC $80 \%$ (Candogan y Kolsarici, 2003; Piñero y col., 2008; Andrés y col., 2011). El rendimiento 
similar de las distintas formulaciones al inicio del almacenamiento puede deberse al estado nativo de las proteínas propias del pescado. En dicho estado las proteínas miofibrilares presentan mayor capacidad para retener líquidos. Durante el almacenamiento congelado, las proteínas del pescado sufren desnaturalización debida al frio lo que conlleva a una menor capacidad de retener líquidos. Esto se relaciona con lo descripto en el Capítulo IV, donde se observó la desnaturalización de la actina y miosina en desmenuzados de saraca correspondientes a diferentes estadios, a lo largo del almacenamiento congelado a $-25^{\circ} \mathrm{C}$ durante 6 meses. Dicha desnaturalización del desmenuzado se reflejó en la menor capacidad tecnológica de retener agua $(\mathrm{WHC})$ y en el aumento en la pérdida de líquido por drip durante el descongelado de desmenuzado.

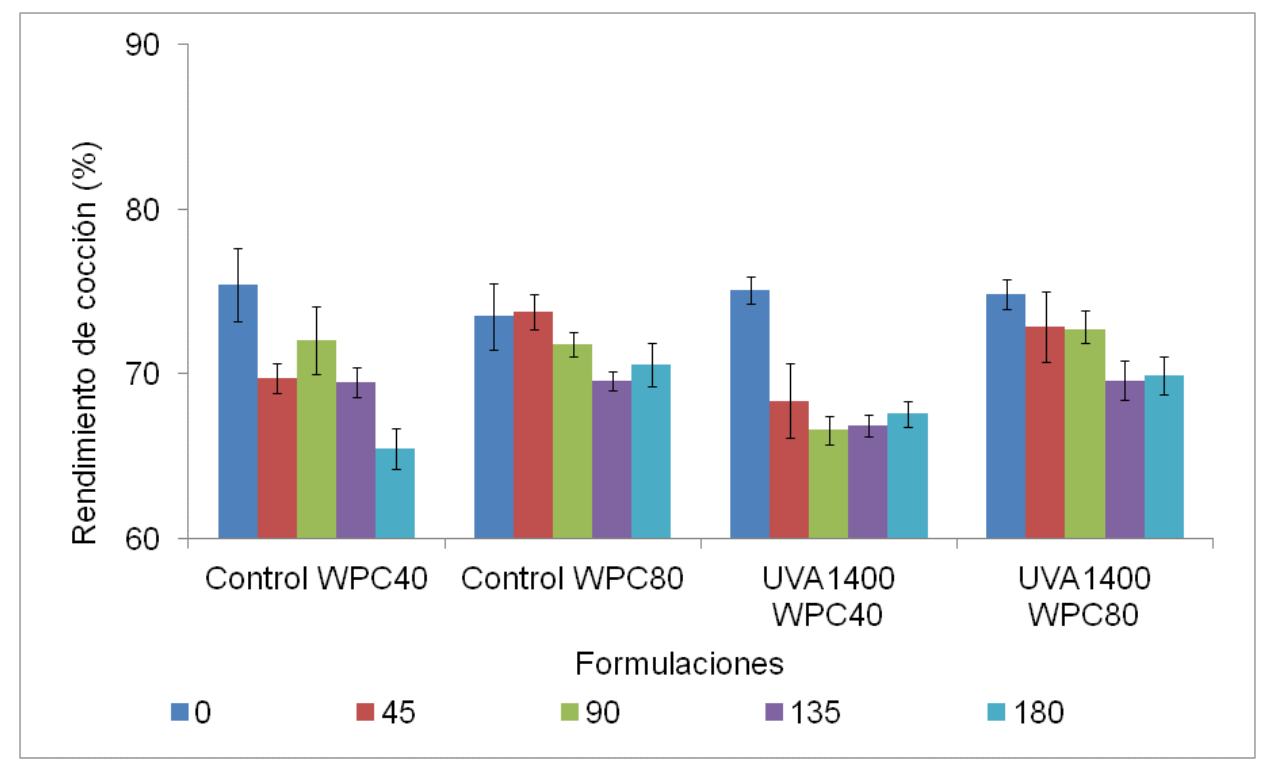

Figura VII - 8: Reducción en el rendimiento de la cocción de las formulaciones ensayadas con el agregado de diferentes sueros de leche. Las barras expresan el error standard de la media.

Además de la influencia del tiempo de almacenamiento sobre el rendimiento, también la concentración proteica del suero lácteo tuvo un efecto significativo $(\mathrm{P}<0.05)$, ya que las formulaciones con WPC80 presentaron los mejores rendimientos en la cocción al finalizar el almacenamiento (Figura VII - 9). Un comportamiento similar fue encontrado por El-Magoli, Laroiab y Hansed (1996) en hamburguesas de carne con el agregado de 0 a 4\% de WPC con $80 \%$ de proteínas y bajo contenido de lípidos, quienes observaron mayores rendimientos en el producto cocido en las formulaciones con mayor contenido de WPC80. Parte del mayor rendimiento también podría estar explicado por el aporte de sólidos del WPC con mayor contenido de proteínas (ElMagoli, Laroiab y Hansed, 1996). 
Las formulaciones con WPC40 presentaron mayores pérdidas en el rendimiento al finalizar el almacenamiento. Se observaron reducciones de un 10 y $13 \%$ para las muestras UVA1400 y Control con WPC40 respectivamente, mientras que las formulaciones con WPC80 presentaron una disminución del rendimiento entre 4 y $6.5 \%$ para las formulaciones Control y UVA1400 respectivamente, al concluir el sexto mes de almacenamiento.

\section{Reducción de tamaño}

Se determinó la reducción de tamaño de los conformados de saraca luego de la cocción. Únicamente tuvieron efecto significativo $(P<0.05)$ el tipo de WPC utilizado y el tiempo de almacenamiento. Las formulaciones con WPC80 presentaron una media de la reducción del tamaño menor que las muestras con WPC40 con valores promedio de $12.19 \pm 2.62 \%$ y $13.69 \pm 2.51 \%$ respectivamente (Figura VII - 10). En relación al tiempo de almacenamiento se observa una continua reducción en el tamaño de los conformados al avanzar el período de almacenamiento, relacionado con la mayor pérdida de humedad de las hamburguesas cocidas, al final del almacenamiento, con respecto a la humedad inicial de los mismos.

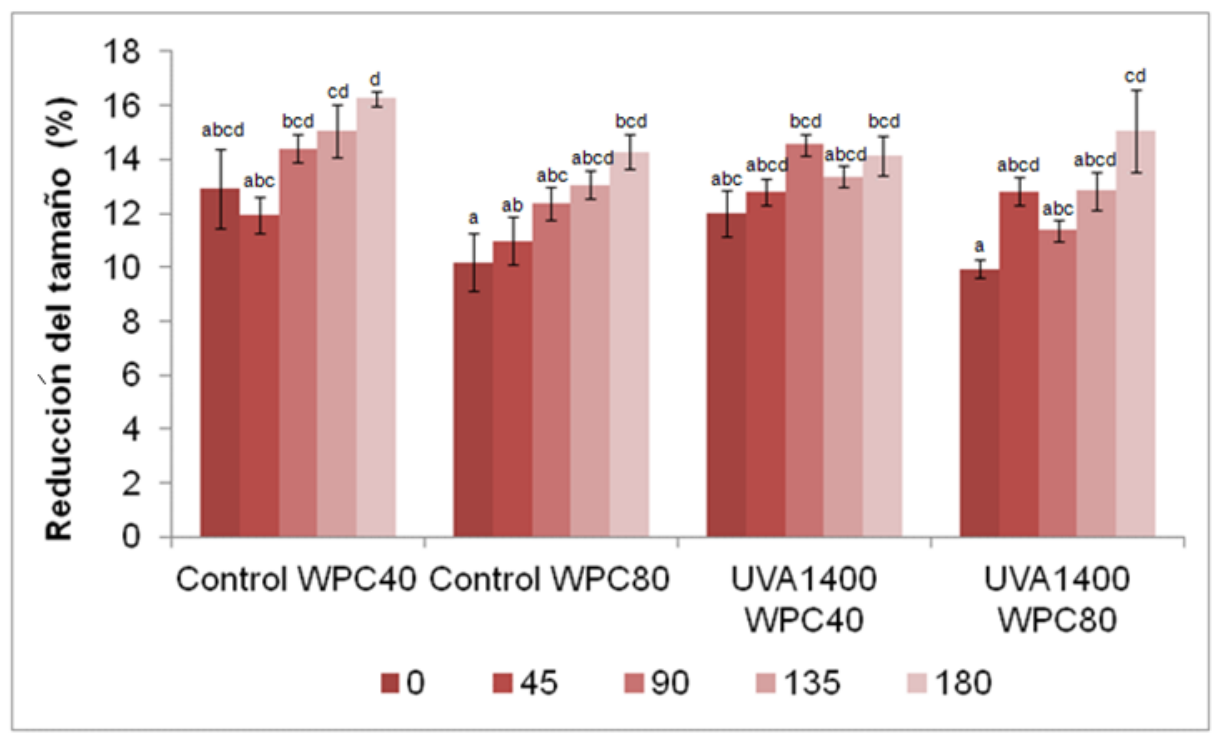

Figura VII - 9: Reducción del tamaño de las formulaciones cocidas de conformados de saraca durante el almacenamiento a $-25^{\circ} \mathrm{C}$. *Valores medios \pm error standard de la media $(n=9) .{ }^{* *}$ Letras diferentes indican que los valores medios difieren significativamente $(P<0,05)$

El tamaño de las hamburguesas de saraca se ve afectado por el proceso de cocción, donde las proteínas musculares se encogen debido a su desnaturalización por efecto del calor, y como consecuencia, pierde agua que a su vez contribuye a la 
reducción del tamaño (Tekin, Saricoban y Yilmaz, 2010). Se observaron valores similares de reducción de tamaño (10\%) en hamburguesas de carne vacuna con formulaciones con WPC 80 (El-Magoli, Laroiab y Hansed, 1996).A su vez cabe destacar que la plancha doble contacto contenía tacos de $1 \mathrm{~cm}$ de contención para evitar que comprimiera los conformados durante la cocción por el peso propio de la placa superior. Es por ello que si bien se observa un comportamiento similar en reducción del tamaño de todas las muestras, la altura final de todos los conformados cocidos fue de $1 \mathrm{~cm}$ sin tener correlación con la altura original de cada hamburguesa cruda.

\section{Retención de agua}

Con respecto a la retención de agua, tanto los factores principales (WPC, antioxidante y tiempo) como las interacciones WPC $x$ tiempo (Figura VII-11a) y WPC $x$ antioxidante (Figura VII-11b) tuvieron efecto significativo $(\mathrm{P}<0.05)$ sobre esta variable. En todas las formulaciones se encontró, un descenso en la capacidad para retener agua de $47.73 \pm 0.42 \%$ a $41.32 \pm 0.48 \%$ al avanzar el tiempo de almacenamiento congelado, si bien la disminución fue más acentuada en aquellos conformados preparados con WPC40 (Figura VII-11a). Al igual que los resultados observados en el

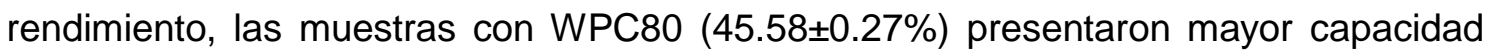
de retener agua luego de la cocción, que las formulaciones con WPC40 $(42.90 \pm 0.27 \%)$.

Se encontraron diferencias significativas entre la retención de agua de las muestras control y con antioxidantes $(45.10 \pm 0.27 \%$ y $43.38 \pm 0.27 \%, P<0.05)$, mientras que ni la interacción antioxidante $x$ tiempo ni la triple influyeron significativamente en los resultados observados $(P>0.05)$. En cuanto al porcentaje de retención de agua luego de 180 días de almacenamiento congelado, solamente la formulación Control WPC80 (44.21 $\pm 1.33 \%)$ difirió significativamente de la retención de las otras tres ensayadas (Control WPC40, UVA1400 WPC40 y UVA1400 WPC80, $39.90 \pm 1.93 \%, 38.56 \pm 1.93 \%, 42.61 \pm 1.90 \%$, respectivamente). Otros autores observaron valores de menor capacidad de retención de agua en productos cárnicos con WPC80 en la misma dosis que este trabajo de investigación, así, El-Magoli, Laroiab y Hansed (1996) presentaron valores de retención de agua entre 41.5 y $44.6 \%$ en medallones de carne sin y con el agregado de WPC80.

La capacidad de retener agua luego de la cocción se relaciona con la propiedad de las miofibrillas de la carne y su interacción proteína-agua. Un comportamiento similar al observado en esta Tesis, fue descripto por Murphy y col. (2005), quienes observaron una menor capacidad de retener agua en geles de merluza adicionados 
con WPC con $45 \%$ de proteínas que en geles adicionados con WPC con $76 \%$ de proteínas de suero de leche. A su vez observaron una mayor capacidad de retener agua al aumentar la concentración del suero en los geles con WPC76, mientras que geles con WPC35 presentaron un comportamiento inverso, a mayor porcentaje de WPC35 menor capacidad de retener agua. Según lo descripto en la Tesis de Campbell (2010) a menor solubilidad de la proteína de suero mayor será su capacidad de fijar agua (Jayaprakasha y Brueckner, 1999). Por lo que, cuanto más desnaturalizada o más cerca del punto isoeléctrico se encuentre menor será su solubilidad, pero mayor será su capacidad de fijar agua. Las propiedades de gelación del concentrado de suero lácteo son responsables de retener los lípidos y el agua que son liberadas de la matriz proteica de la carne cuando ésta se encoge durante la cocción. En forma similar a la fijación de agua, la fijación de la grasa está facilitada por la construcción de un fuerte gel proteico que la atrapa dentro de la matriz proteica y también por la retención de la grasa dentro de las membranas de las células adiposas, las cuales no son sustancialmente rotas por los procesos de picado, lo que previene la pérdida de humedad.

Se debe recordar, además, que en todas las formulaciones se incorporó hexametafosfato de sodio el cual modifica la estructura de las proteínas cárnicas favoreciendo su funcionalidad para retener más agua.
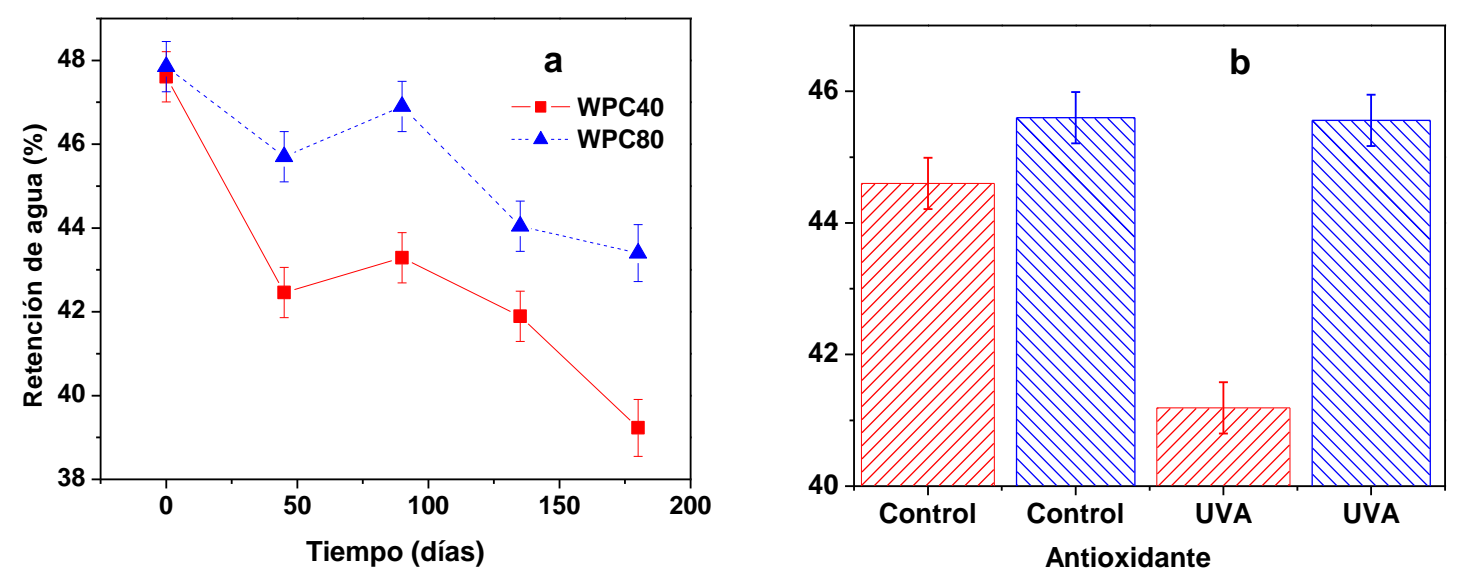

Figura VII - 10: Retención de agua porcentual de conformados cocidos de saraca, individualizados según: su contenido de WPC40 ( $\square$ ) y WPC80 ( $\boldsymbol{\Delta})$, en función de: a) el tiempo de almacenamiento previo a $-25^{\circ} \mathrm{C}$; b) tipo de antioxidante empleado (control y antioxidante de uva 0.14g/100g): WPC40 (ZIZ) y WPC80 (

*Valores promedio \pm error standard de la media. 


\section{Jugosidad por presión}

Los resultados de jugosidad de las muestras cocidas de las diferentes formulaciones desarrolladas, analizadas a lo largo del almacenamiento a $-25^{\circ} \mathrm{C}$, se presentan en la Figura VII - 12. Tanto el tiempo de almacenamiento como el tipo de antioxidante influyeron significativamente en los resultados $(P<0.05)$, lo que no ocurrió con el tipo de WPC. Sin embargo, también fueron significativas las tres interacciones dobles y la triple.

Las muestras con antioxidante de uva presentaron, en promedio, valores superiores a las muestras control $(2.13 \pm 0.80 \%$ y $1.81 \pm 0.60 \%$ respectivamente). La jugosidad promedio de las muestras control fue $1.66 \pm 0.71 \%$ y $1.95 \pm 0.44$ para las formulaciones con WPC40 y WPC80 respectivamente. Mientras que los valores de jugosidad para las muestras con extracto de semillas de uva encontrados fueron 2.17 \pm 0.86 y $2.10 \pm 0.77 \%$ para las formulaciones con WPC40 y WPC80 respectivamente.

Asimismo, la jugosidad se redujo a medida que aumentó el tiempo de almacenamiento en todas las muestras (Figura VII - 12). Al inicio del almacenamiento las hamburguesas que contenían extracto de semillas de uva presentaron valores en la jugosidad superiores a las formulaciones control; los valores de jugosidad correspondientes a WPC40 y WPC80 con antioxidante fueron $3.6 \pm 0.23 \%$ y $3.49 \pm$ $0.28 \%$; en cambio, la jugosidad de las formulaciones control con WPC40 y WPC80 fue $2.69 \pm 0.24 \%$ y $2.22 \pm 0.13 \%$, respectivamente; al final del almacenamiento se alcanzó valores entre 1.15 para control WPC40 y 1.59 para UVA1400 WPC40.

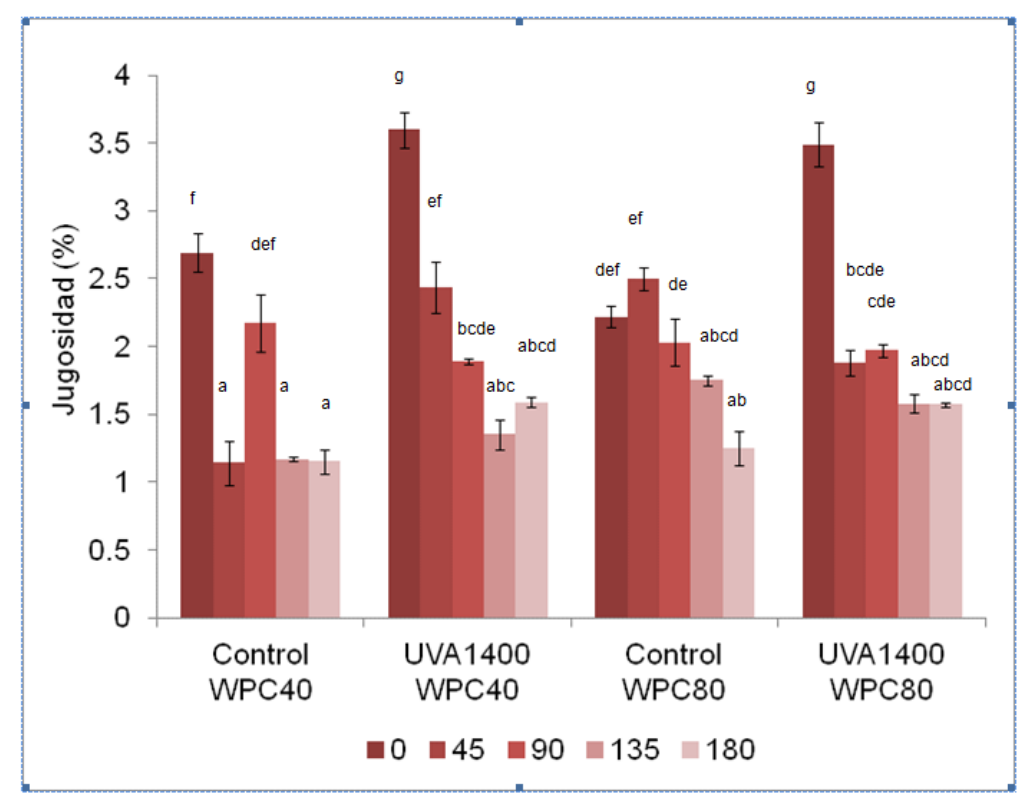

Figura VII - 11: Variaciones de la jugosidad de las formulaciones de

conformados de saraca durante el tiempo de almacenamiento a $-25^{\circ} \mathrm{C}$. * Valores medios y error standard de la media $(n=3) .{ }^{* *}$ Letras diferentes indican que los valores medios difieren significativamente $(P<0.05)$ 
En hamburguesas de carne El-Magoli, Laroiab y Hansed (1996) observaron una mayor jugosidad en las muestras con mayor contenido de WPC, lo que llevó a una mayor aceptabilidad sensorial, también encontraron que el agregado de tripolifosfato (TPP) de sodio favorecía la jugosidad de los productos cocidos. En las formulaciones diseñadas en esta Tesis se incorporó hexametafosfato de sodio el cual podría tener también el mismo efecto que el TPP.

\section{Retención de lípidos}

Se encontró que la interacción de los 3 factores (WPC $x$ tiempo $x$ antioxidante) fue muy significativa $(P<0.002)$. Sin embargo, la presencia o no de antioxidante de semillas de uva no tuvo efecto significativo sobre la retención de lípidos ( $P>0.05)$. La capacidad de retener lípidos al inicio del almacenamiento fue Control WPC40=98.52 \pm $3.1 \%$; Control WPC80=87.23 $\pm 2.88 \%$; UVA1400 WPC40 $=95.52 \pm 2.36 \%$ y UVA1400 WPC80 $=90.63 \pm 3.37 \%$, mientras que al finalizar el almacenamiento los valores correspondientes resultaron: Control WPC40 $=92.09 \pm 4.46 \%$; Control WPC80 $=83.27$ $\pm 2.51 \%$; UVA1400 WPC40 $=95.88 \pm 1.46 \%$ y UVA1400 WPC $80=88.93 \pm 3.46 \%$. En la Figura VII - 13 se presentan todos los resultados obtenidos, las muestras con WPC40 presentaron mayor capacidad de retener lípidos a lo largo del tiempo de almacenamiento, que las muestras con WPC80. También se observó una paulatina disminución en la capacidad de retener lípidos de las diferentes formulaciones con el tiempo de almacenamiento. Esto se relaciona con la pérdida de funcionalidad de las proteínas para retener líquidos.

La funcionalidad de las proteínas de suero de leche depende de varios factores, el tipo de suero a partir de la obtención de queso, los tratamientos de dicho suero hasta obtener el concentrado de proteínas, la concentración de proteínas, los tratamientos posteriores de almacenamiento, influyen en la capacidad de retener agua, lípidos, de emulsificar, etc. (Schmidt, Packard y Morris, 1984; Morr y Ha, 1993; Farkye, 2004; Smithers, 2008). Las proteínas nativas de suero muestran una interacción intramolecular rígida y estable. Las proteínas nativas o con poca desnaturalización se pueden mover rápidamente a la interfase de las emulsiones y formar una cubierta sobre los lípidos. Los tratamientos moderados por calor provocan un desdoblamiento de la estructura de las proteínas de suero, que conducen a una interacción de los sitios reactivos, como grupos tiol (-SH) y que resulta en enlaces disulfuro intermoleculares (SS) y la agregación de las fracciones de proteína (Zevchak, 2007; Watthanpimol, 2011; Christensen, 2012). Estas características podrían explicar la mejor reorientación de las proteínas WPC40, facilitando la interacción lípido-proteína (Lucca y Tepper, 1994). Previamente se observó, en este Capítulo, una mayor 
capacidad antioxidante y menor retención de agua por parte de las WPC40 y se pudo atribuir estas características a un estado menos desnaturalizado de estas proteínas favorecidas por los tratamientos menos agresivos durante su producción. Estos resultados confirmarían este estado menos desnaturalizado respecto de las proteínas de WPC80.

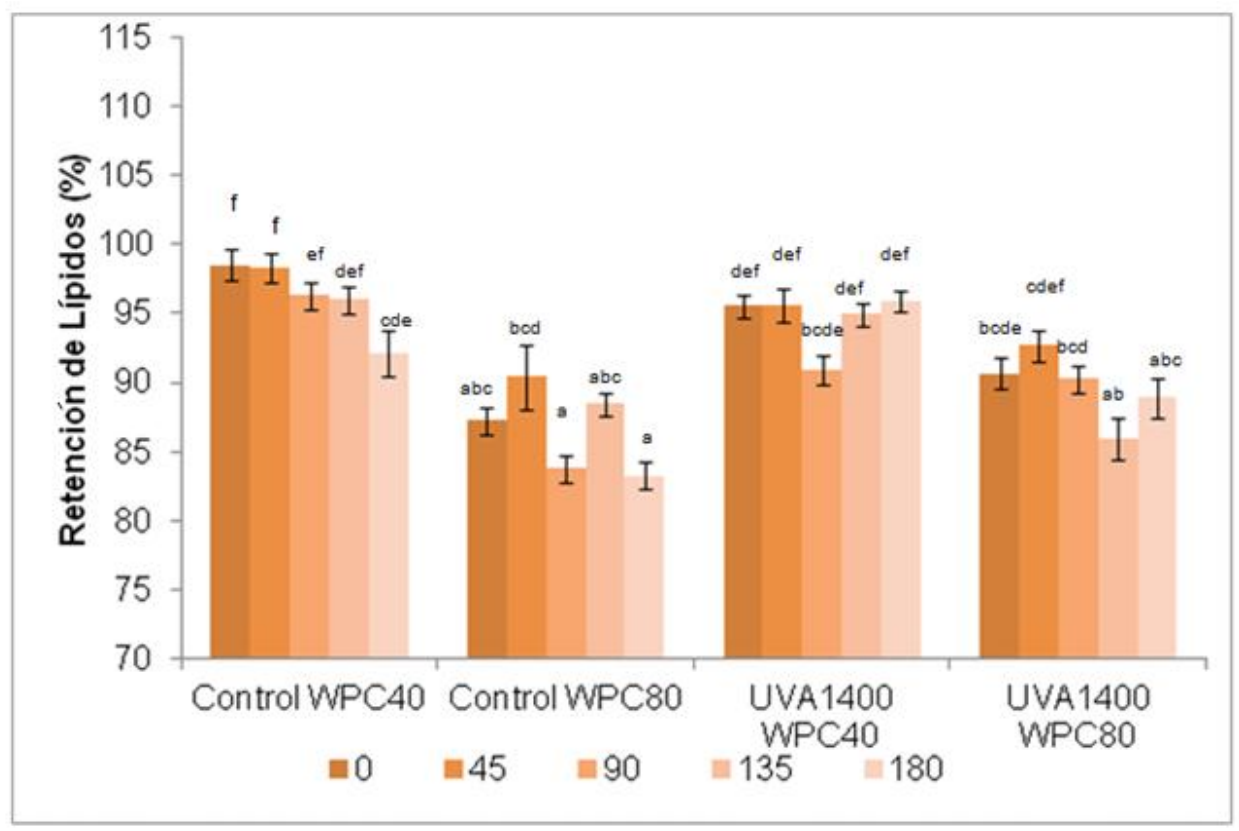

Figura VII - 12: Retención de lípidos de las formulaciones cocidas de conformados de saraca durante el almacenamiento a $-25^{\circ} \mathrm{C}$. *Valores promedio \pm error standard de la media $(n=9) .{ }^{* *}$ Letras diferentes dentro indican que los valores medios difieren significativamente $(P<0,05)$

Sheard, Nute y Chappell (1998), trabajaron con hamburguesas y salchichas de carne reducidas en grasas, observaron una mayor retención de lípidos que en productos con medio y alto contenido de lípidos. Describieron a este fenómeno como característico de los productos reducidos en grasa. La retención de lípidos está relacionada con el contenido de lípidos presente en el producto cárnico. Esta retención disminuye cuanto mayor es el contenido de lípidos en el producto, por ende a medida que disminuye la distancia entre la grasa y las células, mayor es la probabilidad que la grasa colapse durante la cocción y drene desde el producto.

\section{Perfil de ácidos grasos}

El efecto del consumo de ácidos grasos de la familia $n-6$ y $n-3$ ha mostrado propiedades anti-inflamatorias, protegiendo de la aterogenicidad de las células 
cardiovasculares (De Caterina, Liao y Libby, 2000). Los ácidos grasos de cadena larga presentan una implicancia crítica como nutrientes para la salud humana. Existe una gran evidencia clínica y estudios bioquímicos muestran que el consumo de los ácidos grasos eicosapentaenoicos (EPA) y docosahexaenoicos (DHA) presenta beneficios fisiológicos sobre la presión arterial, el estado del corazón, triglicéridos y la reducción del riesgo fatal de las enfermedades coronarias y su consecuente muerte cardiaca (FAO, 1997; Wang y col., 2006; Jacobsen y col., 2008; Claret y col, 2012). Así, Colombo y col. (2013) evaluaron la suplementación con DHA en niños desde los 18 meses de edad hasta los 6 años. No observaron un efecto significativo en los niños a los 18 meses, pero si observaron avances en el desarrollo cognitivo entre los 3 y 5 años. A su vez, el aceite purificado del género Brevoortia fue aprobado para su uso en alimentos para humanos y es considerado como producto GRAS (FDA, 2004) por sus aportes elevados en EPA + DHA cercano al 19.8\%.

En la Tabla VII - 6 se presentan los ácidos grasos principales aportados por los conformados de saraca. Los ácidos grasos más abundantes son el palmítico (16:0), palmitoleico (16:1), oleico (18:1), EPA (20:5) y DHA (22:6). Esta composición se correlaciona con los trabajos previos analizados en el Capítulo III donde el músculo de pescado presenta los mismos ácidos grasos principales a lo largo del ciclo biológico. Además estas observaciones coinciden con los datos reportados por Guner y col. (1998); Karakoltsidis, Zotos y Constantinides (1995); Zlatanos y Laskaridis (2007) y Huynh y Kitts (2009). A diferencia del pescado entero, en las hamburguesas de saraca se encontró un mayor contenido de ácido graso oleico el cual es aportado por el aceite de girasol "alto oleico" incorporado en las formulaciones en una dosis de $3 \%$.

Se observó un efecto significativo debido a los 3 factores principales, las formulaciones con WPC40 y las formulaciones con antioxidante de uva presentaron mayores contenidos de DHA y EPA, mientras que al avanzar el tiempo de almacenamiento se produjo una reducción de los mismos, lo que podría estar relacionado con la oxidación lipídica que ocurre durante el almacenamiento (Tabla VII - 6). Todas las formulaciones presentaron valores entre $59.75 \pm 0.16 \%$ y $65.8 \pm 0.03 \%$ en el contenido total de ácidos grasos insaturados. Se observó que las formulaciones tuvieron un efecto significativo debido al WPC utilizado y al tiempo de almacenamiento. Al inicio del almacenamiento no se observaron diferencias significativas entre las formulaciones pero al avanzar el tiempo de almacenamiento se redujo significativamente el total de los ácidos grasos insaturados. 
Tabla VII- 3: Efecto del tiempo de almacenamiento congelado en el perfil de ácidos grasos (\% del total de ácidos grasos) de los conformados cocidos.

\begin{tabular}{|c|c|c|c|c|c|c|c|c|}
\hline \multirow[b]{2}{*}{ Tipo } & \multicolumn{2}{|c|}{ Control WPC40 } & \multicolumn{2}{|c|}{ Control WPC80 } & \multicolumn{2}{|c|}{$\begin{array}{l}\text { UVA1400 } \\
\text { WPC40 }\end{array}$} & \multicolumn{2}{|c|}{$\begin{array}{l}\text { UVA1400 } \\
\text { WPC80 }\end{array}$} \\
\hline & 0 & 6 & 0 & 6 & 0 & 6 & 0 & 6 \\
\hline C14:0 & $4.44^{d}$ & $3.98^{a}$ & $4.31^{\mathrm{bod}}$ & $4.36^{\mathrm{bod}}$ & $4.52^{d}$ & $4.09^{a b}$ & $4.18^{\mathrm{abc}}$ & $4.18^{\mathrm{abc}}$ \\
\hline C16:0 & $18.54^{\text {ab }}$ & $18.25^{\text {ab }}$ & $18.52^{\text {ab }}$ & $18.47^{\mathrm{ab}}$ & $18.64^{b c}$ & $18.06^{a}$ & $18.73^{b c}$ & $19.14^{\mathrm{C}}$ \\
\hline C18:0 & $3.46^{\mathrm{ab}}$ & $3.78^{b}$ & $3.24^{\mathrm{a}}$ & $3.37^{\mathrm{ab}}$ & $3.75^{b}$ & $3.75^{b}$ & $3.61^{\text {ab }}$ & $3.7^{\mathrm{ab}}$ \\
\hline SFA & $26.46^{\text {ab }}$ & $26.01^{a}$ & $26.05^{a}$ & $26.19^{a}$ & $26.91^{b}$ & $25.91^{a}$ & $26.51^{\text {ab }}$ & $27^{b}$ \\
\hline C16:1 & $5.27^{a}$ & $5.29^{a}$ & $5.53^{a}$ & $5.11^{a}$ & $4.87^{a}$ & $5.78^{a}$ & $5.65^{a}$ & $5.74^{a}$ \\
\hline C18:1 & $43.83^{c}$ & $41.02^{a}$ & $45.12^{d}$ & $42.8^{b}$ & $42.34^{b}$ & $40.29^{a}$ & $45.23^{d}$ & $42.32^{b}$ \\
\hline MUFA & $49.14^{c}$ & $46.31^{a}$ & $50.64^{d}$ & $47.91^{b c}$ & $47.21^{\text {ab }}$ & $46.07^{a}$ & $50.88^{d}$ & $48.06^{b c}$ \\
\hline C18:3 n3 & $0.36^{a}$ & $0.35^{\mathrm{a}}$ & $0.33^{a}$ & $0.36^{a}$ & $0.55^{b}$ & $0.6^{b}$ & $0.59^{b}$ & $0.55^{b}$ \\
\hline C18:4 n3 & $1.73^{\mathrm{a}}$ & $1.55^{\mathrm{a}}$ & $1.59^{\mathrm{a}}$ & $1.69^{a}$ & $1.79^{\mathrm{a}}$ & $1.72^{\mathrm{a}}$ & $1.62^{\mathrm{a}}$ & $1.56^{\mathrm{a}}$ \\
\hline $\begin{array}{l}\text { C20:5 n3 } \\
\text { (EPA) }\end{array}$ & $4.88^{b c}$ & $4.16^{a}$ & $4.82^{b c}$ & $4.74^{\mathrm{bc}}$ & $5.94^{d}$ & $5.05^{c}$ & $4.89^{b c}$ & $4.42^{\mathrm{ab}}$ \\
\hline $\begin{array}{l}\text { C22:6 n3 } \\
\text { (DHA) }\end{array}$ & $8.37^{b c}$ & $7.4^{\mathrm{ab}}$ & $7.5^{\mathrm{ab}}$ & $7.06^{a}$ & $8.93^{c}$ & $8.12^{b c}$ & $7.84^{\mathrm{ab}}$ & $7.05^{a}$ \\
\hline EPA+DHA & $13.19^{b}$ & $11.56^{\mathrm{a}}$ & $12.32^{a b}$ & $11.8^{a}$ & $14.86^{c}$ & $13.17^{b}$ & $12.73^{\text {ab }}$ & $11.45^{a}$ \\
\hline PUFA & $15.29^{b}$ & $13.44^{a}$ & $14.24^{\text {ab }}$ & $13.85^{\text {ab }}$ & $17.21^{c}$ & $15.48^{b}$ & $14.93^{\text {ab }}$ & $13.57^{a}$ \\
\hline$\Sigma$ AG insat. & $64.37^{c}$ & $59.75^{a}$ & $64.88^{c}$ & $61.75^{b}$ & $64.41^{c}$ & $61.55^{a b}$ & $65.8^{c}$ & $61.62^{a b}$ \\
\hline IA & $0.56^{a}$ & $0.56^{a}$ & $0.54^{\mathrm{a}}$ & $0.57^{a}$ & $0.57^{\mathrm{a}}$ & $0.56^{a}$ & $0.54^{\mathrm{a}}$ & $0.59^{a}$ \\
\hline TI & $0.34^{\mathrm{a}}$ & $0.37^{a}$ & $0.34^{\mathrm{a}}$ & $0.37^{a}$ & $0.32^{a}$ & $0.35^{a}$ & $0.35^{a}$ & $0.39^{a}$ \\
\hline
\end{tabular}

* Para cada ácido graso dado, superíndices diferentes indican que hay diferencias significativas $(\mathrm{P}<0.05)$.

Moore y col. (2012) recomiendan un consumo diario de al menos $500 \mathrm{mg} / \mathrm{día}$ de $E P A+D H A$ en los adultos saludables. La American Heart Association recomienda 1000 mg/día para las personas con riesgo cardiovascular (AHA, 2010). En el caso específico de las madres y nodrizas, Valenzuela y Sanhueza (2009), recomiendan un consumo de DHA no menor a $300 \mathrm{mg} /$ día y en el caso de los lactantes y escolares la dosis está en torno a $150 \mathrm{mg}$ de DHA por día. Si analizamos el contenido de EPA + DHA expresado por $100 \mathrm{~g}$ de producto cocido (Tabla VII - 7), se observa que las muestras control aportan menor contenido de EPA + DHA que las muestras con extracto de uva. A su vez las formulaciones con WPC40 aportan mayor cantidad de EPA y DHA esto se relaciona con la mayor capacidad de retener lípidos por parte de 
este suero de leche. El consumo de 100 gramos de hamburguesas de saraca cocidas, en cualquiera de las formulaciones diseñadas, aportarían más que las recomendaciones diarias de $1000 \mathrm{mg}$.

Por otro lado, la composición de los ácidos grasos presentes en los alimentos es más importante que la grasa total de un alimento, en relación al riesgo cardiovascular que pueden producir. En este contexto, conocer el balance entre los ácidos grasos perjudiciales para la salud y los saludables, permite obtener una medida de la calidad de un alimento. Los índices de aterogenicidad (IA) y de trombogenicidad (IT), se utilizan para estimar el efecto de las grasas presentes en un alimento sobre la salud de los consumidores. Valores elevados de IA e IT se relacionan con alimentos ricos en grasas saturadas promotoras del desarrollo de enfermedades coronarias debidas en parte al aumento en los niveles de colesterol y lipoproteínas en sangre (Kaya y Turan, 2010). Se considera que valores de IA e IT mayores a 1 son riesgosos para la salud. En este trabajo se observó que las hamburguesas de saraca presentaron valores de IA e IT entre 0.54 - 0.59 y 0.32 - 0.39 , respectivamente, para todas las formulaciones. Vera y col. (2009) observaron valores de IA de 1.06 en carnes rojas en el corte Longissimus dorsi; Subhadra y col. (2006) informaron índices de IA e IT de 0.54 y 0.43 en aceite de menhaden (Brevoortia spp.), mientras que Valfré, Caprino y Turchini (2003) presentaron valores de 0.37 y 0.57 en carne de trucha arcoíris.

Tabla VII - 4: Aportes de EPA+DHA (g / 100g de producto cocido) correspondientes a productos con distintos tiempos de almacenamiento a $-25^{\circ} \mathrm{C}$. $\mathrm{T} 0=$ inicial, $\mathrm{T} 6=6$ meses de almacenamiento*. También se indica el contenido lipídico porcentual.

\begin{tabular}{lcc} 
Formulaciones & \multicolumn{2}{c}{ Almacenamiento (meses) } \\
Control WPC40 & 0 & 6 \\
(\% lípidos T0=11.57\% y T6= 12.12\%) & $1.53 \pm 0.01^{\mathrm{b}}$ & $1.40 \pm 0.00^{\mathrm{ab}}$ \\
$\begin{array}{l}\text { Control WPC80 } \\
\text { (\% lípidos T0=11.43\% y T6=11.36\%) }\end{array}$ & $1.49 \pm 0.10^{\mathrm{ab}}$ & $1.33 \pm 0.01^{\mathrm{a}}$ \\
$\begin{array}{l}\text { UVA1400 WPC40 } \\
\text { (\% lípidos T0=13.19\% y T6= 14.73\%) }\end{array}$ & $1.96 \pm 0.01^{\mathrm{c}}$ & $1.94 \pm 0.07^{\mathrm{c}}$ \\
$\begin{array}{l}\text { UVA1400 WPC80 } \\
\text { (\% lípidos T0=11.74\% y T6=12.21\%) }\end{array}$ & $1.49 \pm 0.00^{\text {ab }}$ & $1.41 \pm 0.01^{\mathrm{ab}}$ \\
\hline
\end{tabular}

*superíndices diferentes indican que hay diferencias significativas $(\mathrm{P}<0.05)$. 


\section{Valor calórico total}

Este tipo de producto aportaría entre $185-206$ Kcal cada 100 gramos de producto cocido, dependiendo de la formulación estudiada (Tabla VII - 8). Además de ser un producto bajo en calorías, aporta ácidos grasos saludables en concentraciones mayores a las dosis recomendadas. Se incorporaron, también, fitoesteroles en el diseño del producto. Esta incorporación fue principalmente para mejorar el consumo de los mismos que son escasos en nuestras dietas y aportan beneficios saludables. La dosis farmacológica establecida para reducir la absorción intestinal del colesterol como agentes hipocolesteromiantes es de 1.5-2 g (Escurriol y col., 2009), por otro lado, el contenido de fitoesteroles en la dieta habitual es similar al del colesterol (150$450 \mathrm{mg} /$ día) (Ostlund y col. 2002). Por lo cual la adición de $0.8 \%$ de fitoesteroles en las hamburguesas de saraca, aporta más del $40 \%$ de la dosis farmacológica recomendada y aumentando los niveles en el consumo habitual de fitoesteroles.

Esta dosis ayuda a reducir el riesgo de enfermedades coronarias, disminuyendo tanto el colesterol total en sangre como el colesterol de baja densidad (LDL). A su vez el producto se diseño bajo en sal de sodio agregada $(0.7 \%)$ y sin la incorporación de harina de trigo en forma de pan rallado, procedimiento utilizado en la industria. De esta manera, el producto es apto para diferentes grupos de consumidores que se encuentren comprometidos en su salud por ser hipertensos, hipercolesterolémicos 0 incluso celíacos.

Tabla VII- 5: Aporte calórico cada 100g de productos cocidos.

\begin{tabular}{|lc|c|}
\hline Formulación & \multicolumn{2}{c|}{$\begin{array}{c}\text { Kcal/100g producto } \\
\text { cocido }\end{array}$} \\
\hline Control WPC 40 & 0 & 6 \\
Control WPC80 & 185.53 & 195.76 \\
UVA1400 WPC40 & 190.19 & 189.20 \\
UVA1400 WPC80 & 206.43 & 225.89 \\
\end{tabular}

\section{Textura}

Se realizó un Análisis de Perfil de Textura (TPA) en hamburguesas de saraca cocidas. En la Figura VII - 14 se observa, a modo de ejemplo, un perfil de textura correspondiente a un conformado de saraca cocido al inicio del almacenamiento a -25 ․ C. En los perfiles de textura obtenidos se observó que las muestras no presentaron fracturabilidad ni adhesividad en ninguna de las muestras analizadas. 
En relación a la dureza, se observó que únicamente el tipo de concentrado proteico de suero lácteo y el tiempo de almacenamiento congelado influyeron significativamente $(\mathrm{P}<0.05)$. Las formulaciones con WPC40 presentaron valores medios menores a los observados en las formulaciones con WPC80 $(201.47 \pm 5.04 \mathrm{~N}$ vs. $221.07 \pm 5.04 \mathrm{~N}$, Figura VII - 15).

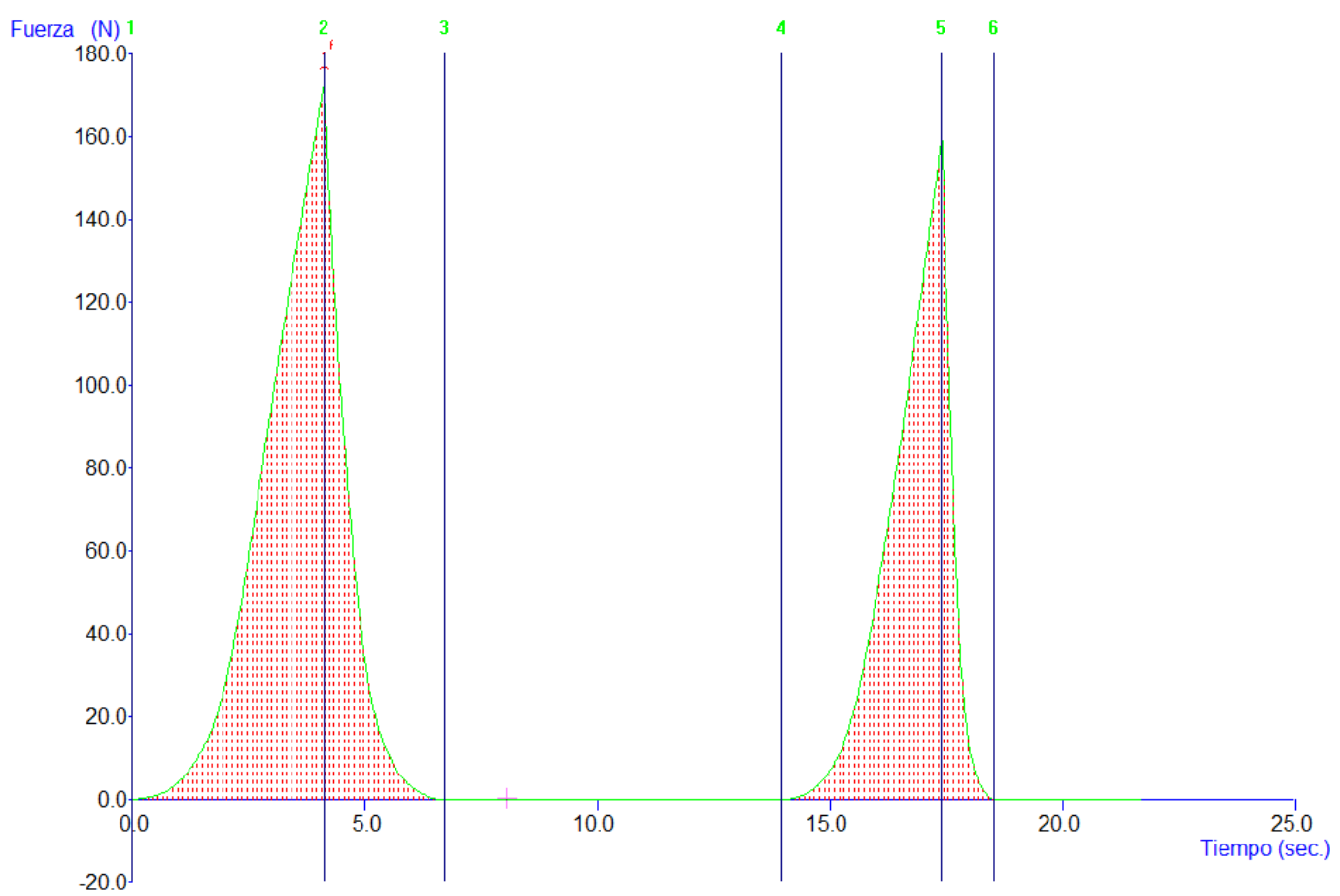

Figura VII - 13: Análisis de Perfil de Textura conformado de saraca cocido, correspondiente a la formulación WPC80 UVA1400, al inicio del almacenamiento a $25^{\circ} \mathrm{C}$,

Este comportamiento coincide con lo informado por Anese y Gormley (1996) quienes evaluaron el efecto del agregado de diferentes productos y subproductos de la industria láctea sobre las propiedades funcionales durante la congelación de desmenuzado de pescado de diferentes especies bacalao dorado (Gadus morhua), eglefino (Gadus aeglefinus) y salmón (Salmo salar). Estos autores, trabajando con agregados de WPC con 35 y $80 \%$ de proteína de suero de leche, observaron que las muestras con WPC80 presentaron para todas las especies valores superiores en la dureza que las formulaciones con WPC 35. También informaron una relación particular entre la capacidad de retener agua, la dureza y el agua circundante de las proteínas de pescado. Observaron que las muestras que presentaron menor capacidad de retener agua tenían mayor dureza. Anese y Gormley (1996) atribuyó la razón de este comportamiento del WPC80 a una distribución de las proteínas lácteas entre las 
proteínas del pescado facilitando una extensa reticulación de las mismas lo que conduce a un gel más firme y con menor WHC. Por el contrario, las proteínas lácteas como WPC35 y caseínas que confieren una mayor WHC, puede deberse a una mejor distribución de las proteínas a lo largo de la matriz del pescado, causando una dilución del pescado picado, lo que resulta en un debilitamiento del gel. El efecto de dilución de algunos de los productos lácteos se puede atribuir a una fuerte interacción proteína de suero de leche y agua debido a la capacidad de hidratación de estos materiales. La formación de complejos de proteína del pescado y las proteínas del suero de leche, se produce principalmente mediante la formación de enlaces de hidrógeno, esto podría ayudar a evitar que las proteínas de pescado se agreguen por lo tanto inhibir la desnaturalización durante la congelación y el almacenamiento congelado.

El tiempo del almacenamiento también influyó en la dureza de los conformados. Presentaron una menor dureza al inicio del almacenamiento, aumentando significativamente en los diferentes periodos analizados. Como se dijo previamente, al aumentar el tiempo de almacenamiento disminuyó el rendimiento en la cocción debido a una menor capacidad de retener agua de las matrices, aumentando la dureza. Un efecto similar fue encontrado por Sanchez-Alonso, Hají-Maleki y Borderías (2007) y por Andrés y col., (2011) trabajando en productos cárnicos almacenados.

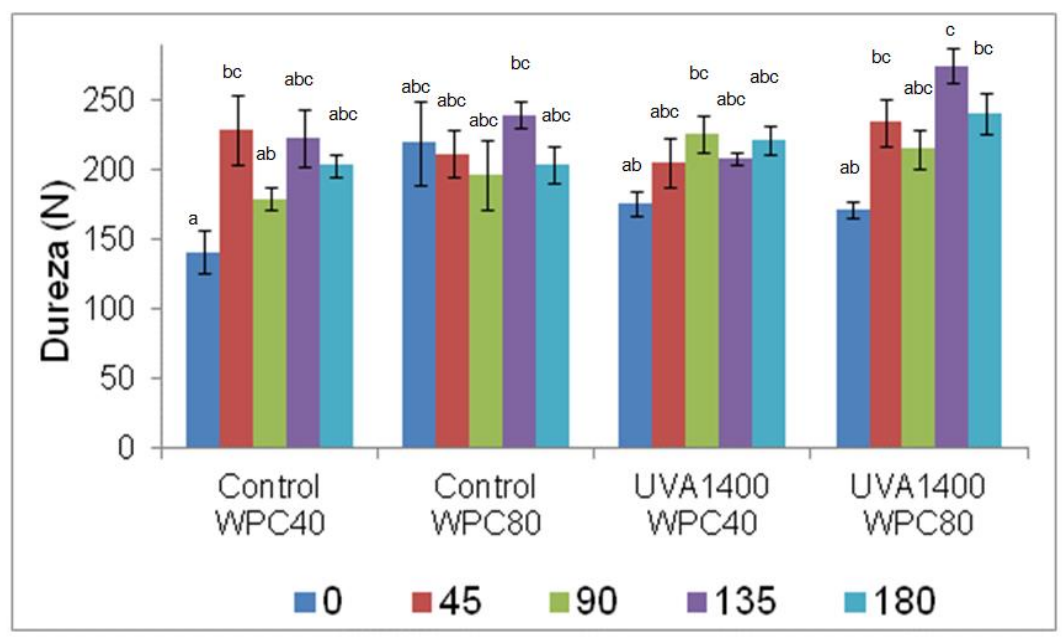

Figura VII - 14: Dureza de las formulaciones de hamburguesa de saraca con el agregado de WPC40 o WPC80. *Valores promedio \pm error standard de la media $(n=4)$.

${ }^{*}$ superíndices diferentes indican que hay diferencias significativas $(P<0.05)$.

La desnaturalización de las proteínas ha sido asociada con los cambios en la textura observados en el músculo de pescado almacenado congelado, tal como el "endurecimiento". También se encuentra relacionada con otras alteraciones funcionales tales como un aumento en la pérdida de fluídos, cambios en las 
propiedades de unión y de gelación (Tironi, 2005). Este comportamiento se correlaciona con los valores observados entre la dureza y la jugosidad, a mayor jugosidad, menor dureza (Figura VII-16).

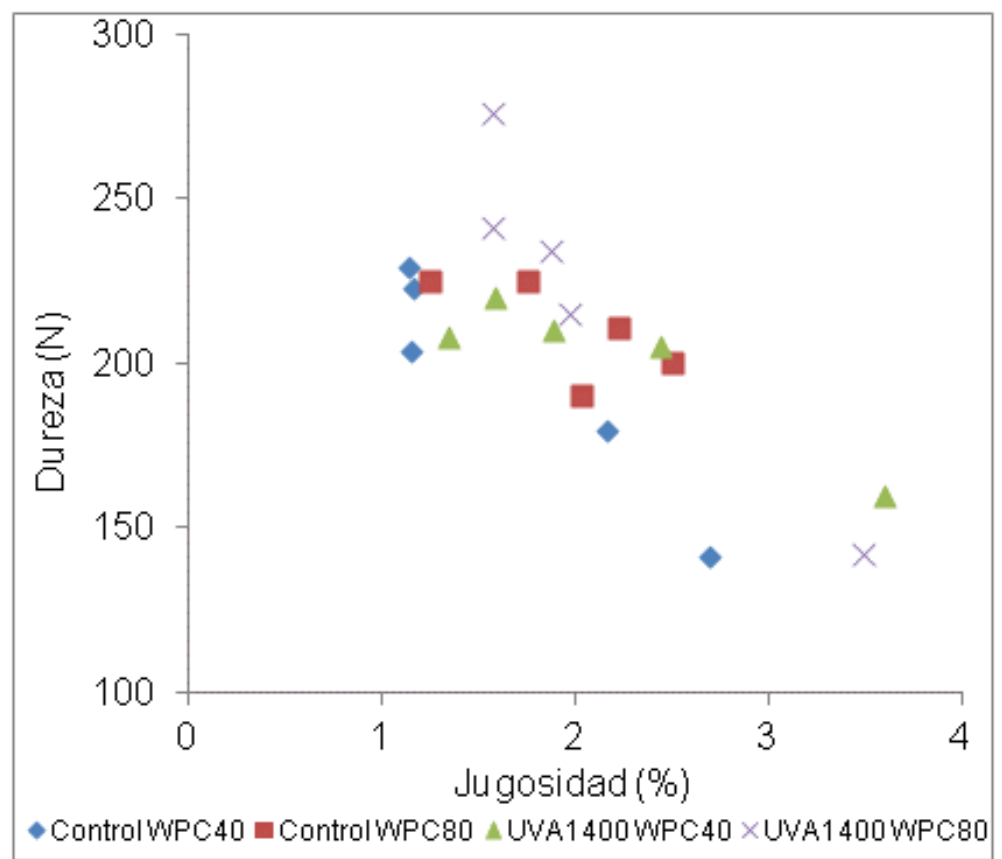

Figura VII - 15: Correlación entre dureza y jugosidad de los productos cocidos.

Al disminuir la temperatura del tejido, el agua presente (aproximadamente 89-90 $\%$ a -20 y $-30^{\circ} \mathrm{C}$ ) se transforma en cristales de hielo. Estos crecen desde la superficie hacia el centro de la pieza a expensas del agua del interior de las fibras, causándoles deshidratación. Esto genera distorsión en la estructura fibrilar y un mayor daño en el tejido que lleva a una menor retención de agua (Wagner y Añón, 1985).

Por otro lado, parte del agua queda como una fracción de agua no congelable debido a que los componentes no acuosos se concentran; la cual no se congela y está ligada a las proteínas. Este aumento en la concentración incrementa la fuerza iónica, causando un desplegamiento de las proteínas, cambiándole sus estructuras tridimensionales, desfavoreciendo las interacciones proteína-agua e induciendo las interacciones proteína-proteína y consecuentemente su agregación. Las proteínas en este estado tienen menos capacidad para retener agua, alterando la jugosidad de los productos. A su vez al estar agregadas, las proteínas miofibrilares le confieren mayor dureza al producto. Este proceso se acentúa debido al aumento del tamaño de los cristales de hielo debido al fenómeno de recristalización que tiene lugar durante el almacenamiento a $-25^{\circ} \mathrm{C}$. 
La adhesividad se relaciona con la cantidad de producto adherido a los dientes luego de la masticación. En este trabajo, ninguna de las formulaciones presentó adhesividad luego de la primera compresión. Esto se relaciona con las características propias del producto el cual no es gomoso ni pegajoso.

La cohesividad describe el parámetro de textura que relaciona la cantidad de deformación que sufre un alimento antes que se produzca la ruptura al morderlo entre los molares. La cohesividad relaciona la recuperación del alimento luego de la segunda compresión; si el alimento se deformó poco, el valor de cohesividad es cercano a 1. Sólo se observó efecto significativo $(\mathrm{P}<0.05)$ sobre este parámetro debido al uso del antioxidante y a la interacción triple, siendo la media de las muestras con UVA1400 (0.66 \pm 0.003$)$ y las muestras Control (0.67 \pm 0.003$)$ (Figura VII-17).

En hamburguesas de pescado con el agregado de fibra los autores SanchezAlonzo y Borderias (2008) observaron reducciones significativas en la cohesividad de sus productos cocidos, informando valores para hamburguesas sin fibra de $0.51 \pm 0.01$ y con el agregado de fibra de 0.46 , levemente menores a los observados en esta Tesis. Este parámetro tampoco varió significativamente a lo largo del almacenamiento.

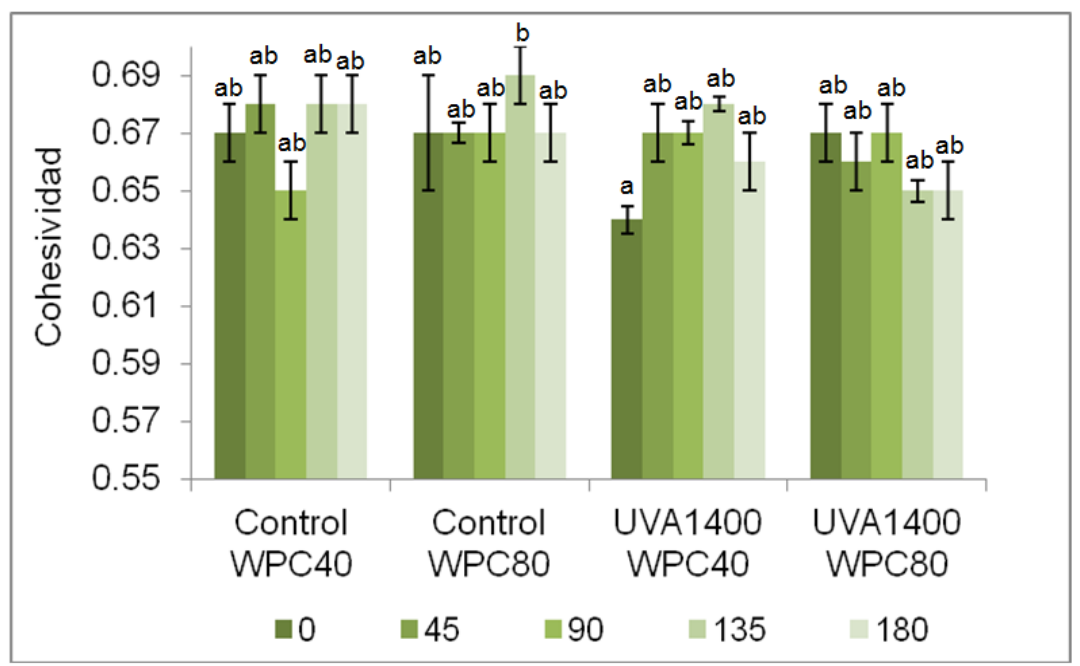

Figura VII - 16: Cohesividad de las formulaciones de saraca durante el almacenamiento congelado a $-25^{\circ} \mathrm{C}$. *Valores promedio \pm error standard de la media $(n=4)$. *superíndices diferentes indican que hay diferencias significativas

$$
(P<0.05) \text {. }
$$

En el caso de la elasticidad se encontraron efectos debidos al antioxidante, al tiempo de almacenamiento, a la interacción doble (tiempo $\mathrm{x}$ antioxidante) y a la interacción de los 3 factores (tipo de WPC x antioxidante $x$ tiempo), Se observó que 
todas las formulaciones presentaron valores entre 0.8 y 0.9 (Figura VII - 18), cercanos a la unidad por lo que la deformación de la segunda compresión fue levemente menor respecto a la deformación producida en la primera compresión. Se observó una menor elasticidad a tiempo 0 aumentado a los 45 días sin presentar diferencias durante el almacenamiento congelado.

La elasticidad fue mayor para las formulaciones sin antioxidante $(0.92 \pm 0.01)$ que en las formulaciones con extracto de semillas de uva $(0.89 \pm 0.01)$ y aumentó a lo largo del almacenamiento congelado. Este comportamiento fue también informado por López-Caballero y col. (2005) quienes trabajaron con hamburguesas de pescado sin cobertura. Valores similares fueron observados en geles de bacalao dorado (Gadus morhua), eglefino (Gadus aeglefinus) y salmón (Salmo salar) con el agregado de suero de leche WPC35 y WPC80 (Anese y Gormley, 1996). Dichos autores reportaron valores de elasticidad porcentual en geles con WPC35 de 84.0\%, 76.0\%, 92.5\% para bacalao, eglefino y salmón respectivamente, y de $81.1 \% 79.0 \%$ y $91.5 \%$ para geles con WPC80 de desmenuzado de bacalao, eglefino y salmón respectivamente.

Los ingredientes lácteos con buena solubilidad pueden presentar una fuerte interacción proteína-agua, lo que se relaciona con su buena habilidad para retener el agua asociado a la buena elasticidad (Anese y Gormley, 1996).

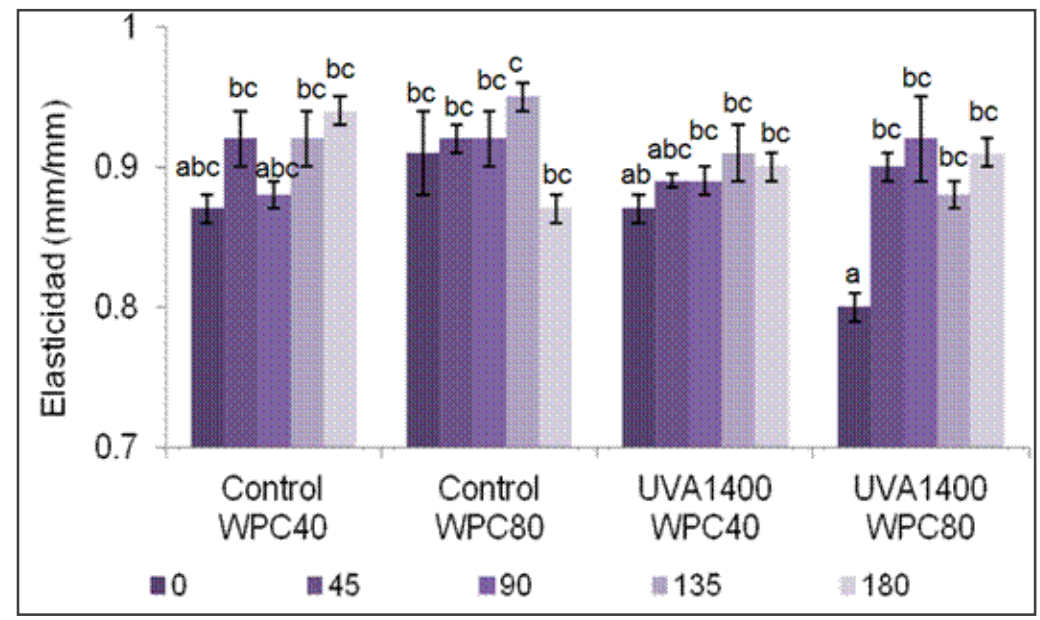

Figura VII - 17: Elasticidad de las formulaciones de saraca durante el almacenamiento congelado a $-25^{\circ} \mathrm{C}$. *Valores promedio \pm error standard de la media $(n=4)$.

*superíndices diferentes indican que hay diferencias significativas $(P<0.05)$.

La masticabilidad es un parámetro secundario que relaciona los valores de Dureza $x$ Cohesividad $x$ Elasticidad y está relacionado con el esfuerzo requerido para desintegrar un producto sólido y llevarlo a un estado listo para ser tragado (Bourne, 2002). En relación a la masticabilidad se encontraron efectos significativos debidos al 
suero de leche utilizado, al tiempo de almacenamiento, a la interacción tiempo $x$ antioxidante y la interacción de los 3 factores (tipo de WPC $x$ antioxidante $\mathrm{x}$ tiempo). Las muestras con WPC80 presentaron valores de masticabilidad mayor que las muestras con WPC40. Asimismo, durante el almacenamiento a $-25^{\circ} \mathrm{C}$ se observa un continuo crecimiento en los valores de masticabilidad para las formulaciones UVA1400 WPC40 y UVA1400 WPC80, mientras que las formulaciones control, si bien presentan el comportamiento creciente, el mismo presenta fluctuaciones (Figura VII - 19). Sanchez-Alonso, Haji-Maleki y Borderias (2007) observaron valores de masticabilidad menores a los reportados en esta Tesis, con valores de 35 ( $\mathrm{N} \times \mathrm{mm}$ ) en hamburguesas de merluza y $62.34(\mathrm{~N}$ x mm) en hamburguesas de caballa. A su vez observaron reducciones en la masticabilidad de las muestras adicionadas con fibra vegetal, la cual interfiere las interacciones proteína-proteína. La diferencia entre los valores observados y los valores presentados por los otros autores, podría deberse a un mayor número de interacciones proteína pescado-proteína láctea en las formulaciones con WPC, con el consecuente aumento en el número de proteínas agregadas produciendo una red proteica más firme, así como a la distinta granulometría del material desmenuzado y en el diferente grado de compactación de la mezcla alcanzado durante la formación de la hamburguesa.

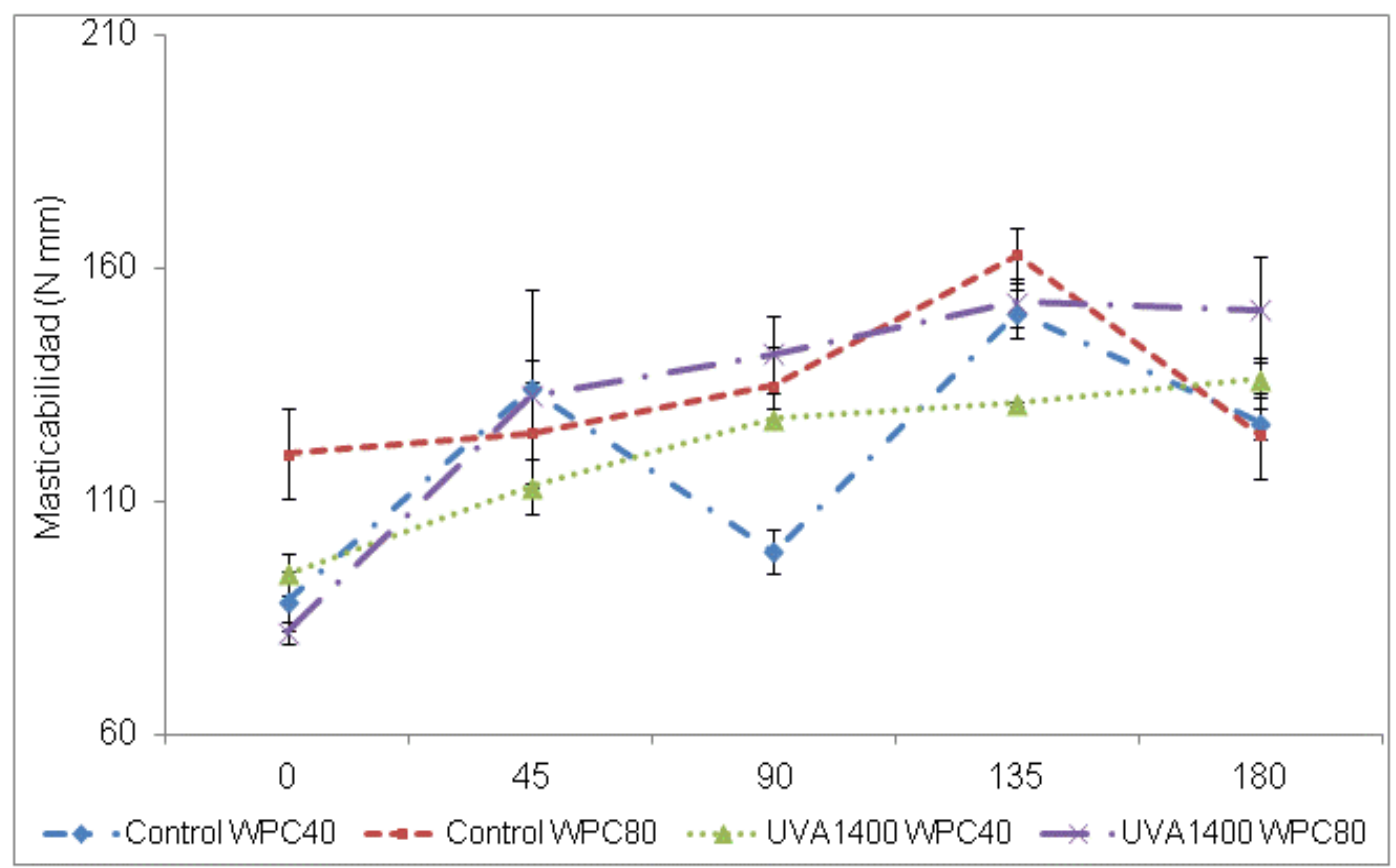

Figura VII - 18: Valores medios de masticabilidad de hamburguesas de saraca durante el almacenamiento congelado. La barra indica error standard de la media $(n=4)$. 
Color

Se determinó el color de la superficie de los conformados preparados con las diferentes formulaciones. A simple vista se observó el color dorado característico de productos cárnicos cocidos por contacto con placa calefactora, pero no homogéneo en toda la superficie. Esta ausencia en la homogeneidad depende del contacto entre las superficies del producto y placa de cocción. La superficie del producto es irregular por los trozos de desmenuzado que la componen, sin presentar una estructura de gel homogéneo (Figura VII - 20).

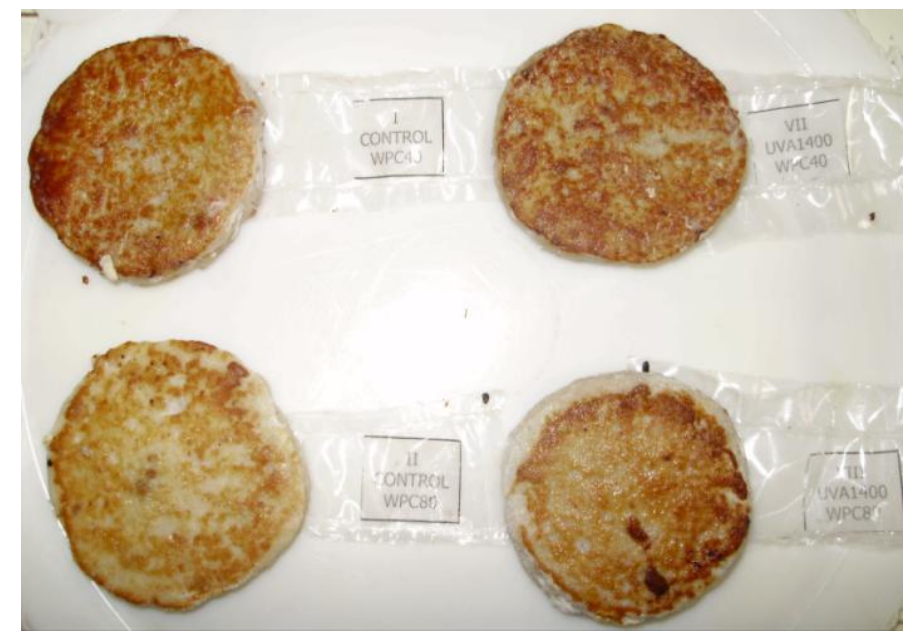

Figura VII - 19: Coloración superficial de hamburguesas cocidas de saraca.

Arriba= Izquierda: Control WPC40, Derecha: UVA 1400 WPC40;

Abajo= Izquierda: Control WPC80, Derecha: UVA 1400 WPC80.

Con respecto a la luminosidad, las muestras con WPC40 presentaron valores de $L^{*}$ menores a los observados en las muestras con WPC80; asimismo se observó un efecto significativo debido a las interacciones (tiempo $x$ antioxidante) y (antioxidante $x$ WPC). Así, la utilización del extracto de semillas de uva redujo la luminosidad en la superficie cocida de las formulaciones con WPC80 respecto del control. A lo largo del tiempo de almacenamiento, todas presentaron un descenso del valor $L^{*}$ entre los $0 \mathrm{y}$ 45 días, seguido de un aumento significativo posterior, manteniéndose sin diferencias significativas a partir de los 90 días, hasta alcanzar el final del almacenamiento (Figura VII - 21).

El efecto debido al tipo de WPC utilizado se podría relacionar con un mayor pardeamiento en las muestras con WPC40 debido al mayor contenido de lactosa lo que provocó una disminución de la luminosidad. La lactosa se utiliza como ingrediente alimentario en varios productos debido a sus propiedades estabilizantes de proteínas, mejorador de textura y a su bajo poder endulzante. También se añade en productos de 
bollería para que se produzca el pardeamiento de Maillard controlado, reacción que producida en exceso se considera negativa en muchos alimentos, aumentando el rechazo por parte de los consumidores (Varnam y Sutherland, 1995). Mientras que el descenso en la luminosidad debido a la aplicación del antioxidante podría deberse directamente a una coloración conferida por el color propio del extracto de semillas de uva.

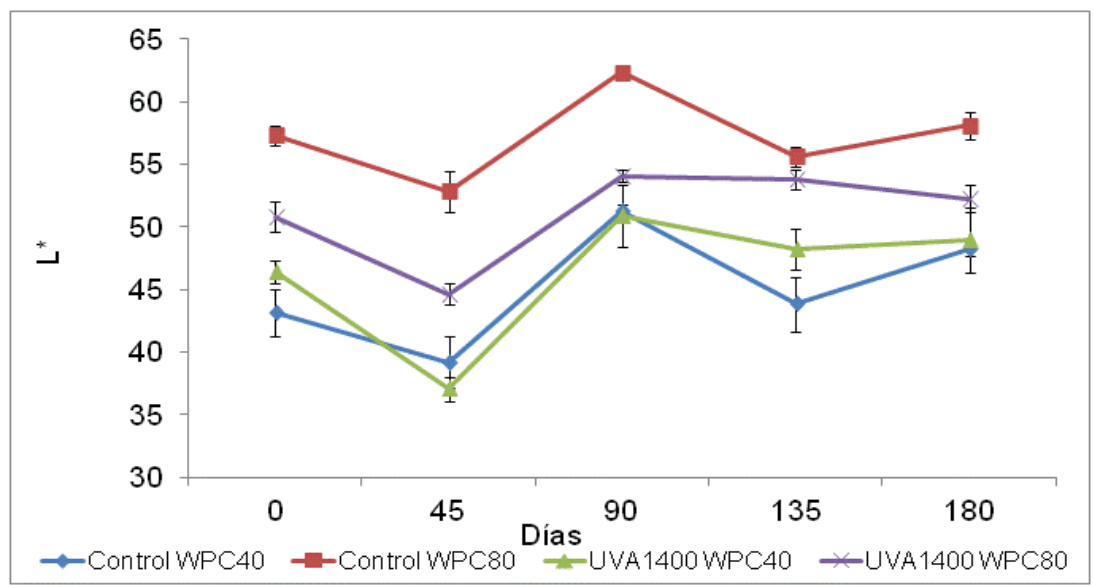

Figura VII- 20: Luminosidad superficial de las formulaciones de saraca cocidas. *Valores promedio \pm error standard de la media $(n=8)$.

En la Figura VII - 22 se muestra el comportamiento del parámetro $a^{*}$ de los conformados de saraca a lo largo del almacenamiento de pescado. Todas las muestras presentaron valores positivos de $\mathrm{a}^{*}$, lo que se relaciona con el color rojo. En relación a este parámetro se observó que las muestras presentaron un efecto significativo debido a las interacciones dobles (antioxidante $x$ WPC) y (tiempo $x$ antioxidante), mientras que el almacenamiento congelado no produjo variaciones significativas sobre el color rojo. La muestra Control WPC80 fue la que presentó valores menos rojizos $\left(<\mathrm{a}^{*}\right)$ durante todo el ensayo. Las muestras con extracto de semillas de uva no presentaron diferencias significativas entre sí, mientras que las muestras control, sin antioxidante, con WPC40, mostraron una coloración más rojiza en la superficie de las hamburguesas cocidas que las formulaciones con WPC80 lo que también podría estar relacionado, como lo observado en $L^{*}$, el mayor contenido de lactosa en el concentrado con $40 \%$ de proteínas favoreció las reacciones de pardeamiento no enzimático.

El parámetro positivo $b^{*}$ se relaciona con el color amarillo. Este parámetro presentó diferencias significativas debidas a los 3 factores. Al inicio del 
almacenamiento no se observaron diferencias entre las cuatro formulaciones, presentando valores iniciales entre $25.58 \pm 0.86$ y $29.38 \pm 2.93$ (Figura VII -23 ).

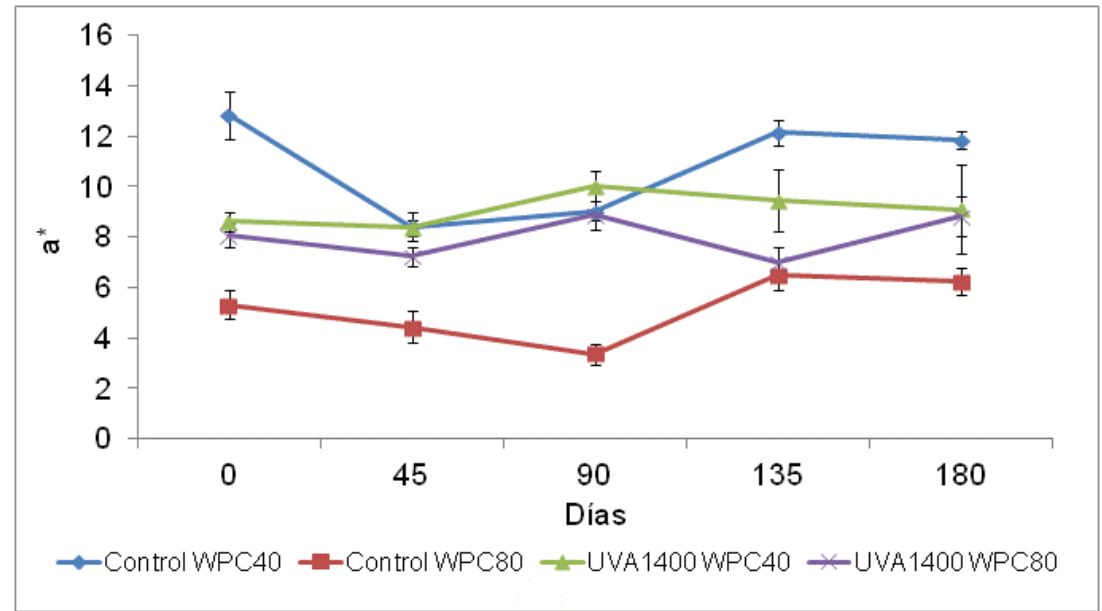

Figura VII- 21: Valores de $a^{*}$ superficial de las formulaciones de saraca cocidas.

${ }^{*}$ Valores promedio \pm error standard de la media $(n=8)$.

A lo largo del almacenamiento congelado, el parámetro b* se redujo en todas las formulaciones hasta cumplir un período de 45 días, seguido de un aumento hasta el día 90. Las muestras con WPC80 presentaron valores mayores respecto a las muestras con WPC40 que se relaciona con una coloración más amarilla. Con respecto a la incorporación de antioxidante de extracto de semillas de uva, al finalizar el período de almacenamiento a $-25^{\circ} \mathrm{C}$ estas muestras presentaron valores de $b^{*}$ inferiores, lo que se podría relacionar con una menor formación de compuestos amarillos característicos de la oxidación de los lípidos. Los valores elevados de $a^{*}$ y b* se relacionan con la mayor presencia de pigmentos formados durante el proceso de cocción.

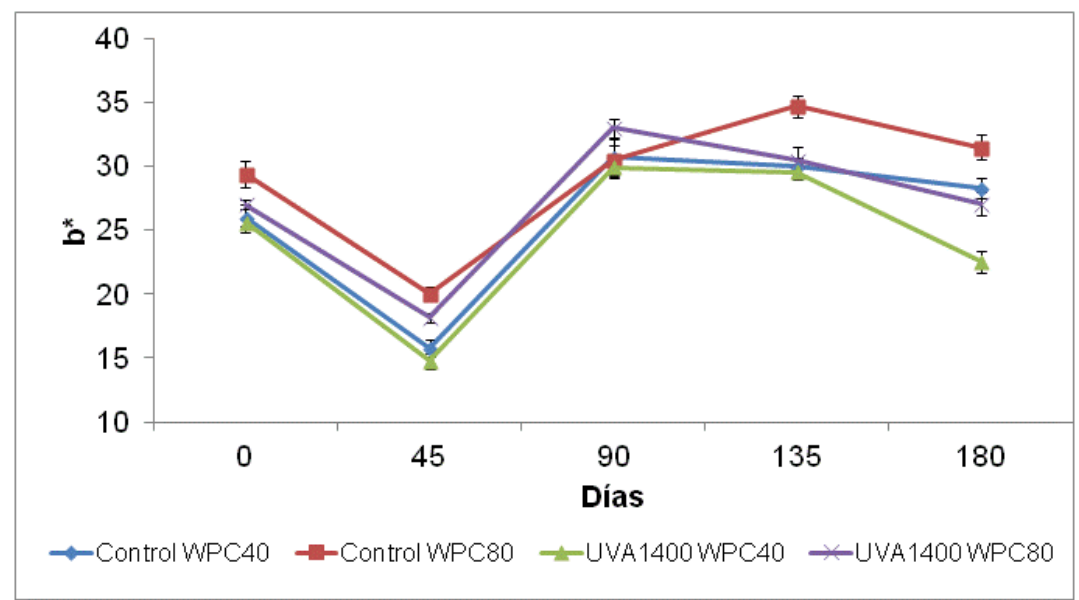

Figura VII- 22: Valores de $\mathrm{b}^{*}$ superficial de las formulaciones de saraca cocidas.

*Valores promedio \pm error standard de la media $(n=8)$. 
El color interno de las formulaciones a simple vista fue blanco marfil (Figura VII - 24), color característico del pescado blanco cocido y muy similar al color interno de los productos empanados de pescado comercializados pre-fritos.

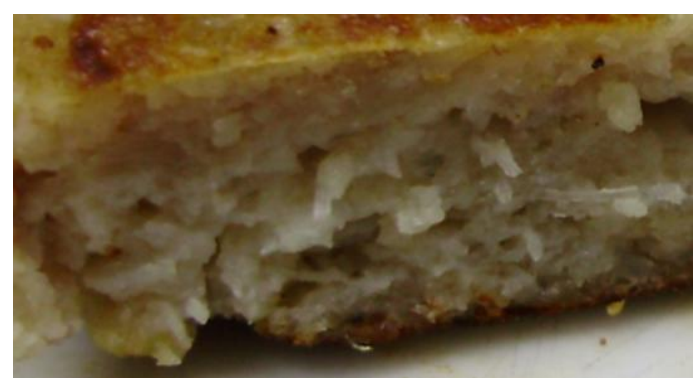

Figura VII- 23: Corte transversal de conformado de saraca cocido

Las muestras presentaron diferencias en su blancura (W) interna desde el inicio del almacenamiento (Figura VII - 25). Se observó que las muestras con WPC40 presentaron valores de W menores que las formulaciones con WPC80 a lo largo del almacenamiento, mientras que el agregado de antioxidante (extracto de semillas de uva) disminuyó la blancura de las muestras cocidas. El tiempo de almacenamiento, en cambio, aumentó los valores de W para todas las formulaciones ensayadas. El color propio del antioxidante (anaranjado) podría estar interfiriendo en la blancura del producto cocido.

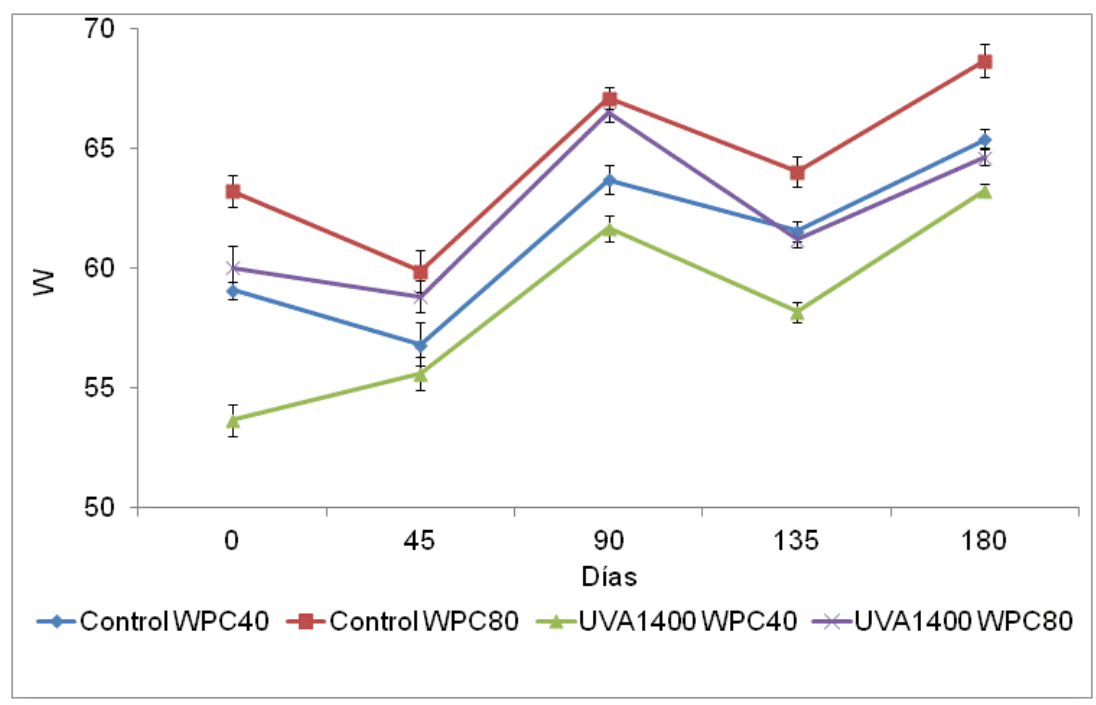

Figura VII- 24: Blancura del color interno de las hamburguesas de saraca cocidas durante su almacenamiento congelado a $-25^{\circ} \mathrm{C}$ durante 6 meses. ${ }^{*}$ Valores promedio \pm error standard de la media $(n=8)$. 
Los valores de $a^{*}$ para el interior del producto fueron positivos en todas las formulaciones pero sumamente bajos, cercanos a cero, asociándose con una baja carga de pigmentos presentes en el músculo blanco del pescado (Figura VII - 26). Generalmente en los alimentos cárneos este valor se relaciona con el color propio de las mioglobinas presentes por el músculo rojo. En el caso de la Brevoortia aurea encontramos músculo rojo entre el músculo blanco y la piel a lo largo de la superficie externa del filete, y este músculo es precisamente rico en mioglobina (ver figura VII-7: Corte transversal de filete de saraca con grasa subcutánea (GS) entre musculo y espejo de plata). Durante el cuereado de los filetes, previo a realizar el desmenuzado, se buscó eliminar parte del músculo rojo ubicado entre la piel y el músculo blanco. De esta manera se redujo el contenido de mioglobina y también del hierro presente en la misma, el cual es precursor en la reacción de oxidación de los lípidos.

Las formulaciones con extracto de uva presentaron valores superiores respecto de las muestras control y se podría asociar con el color rojizo propio del antioxidante presentando una media de $2.01 \pm 0.47$ y $1.16 \pm 0.37$ para el extracto de uva y control respectivamente. Por otro lado, no se observaron diferencias debidas al tipo de WPC utilizado. La formulación Control WPC40 no presentó cambios significativos a lo largo del almacenamiento. En relación al efecto por la interacción entre antioxidante x WPC, se observó que las muestras Control WPC80 presentó una media menor respecto a las otras formulaciones $(1.01 \pm 0.35)$ seguido por la muestra Control WPC40 (1.32 \pm 0.33), UVA1400 WPC40 (1.79 \pm 0.46$)$ y por UVA1400 WPC80 (2.22 \pm 0.37$)$

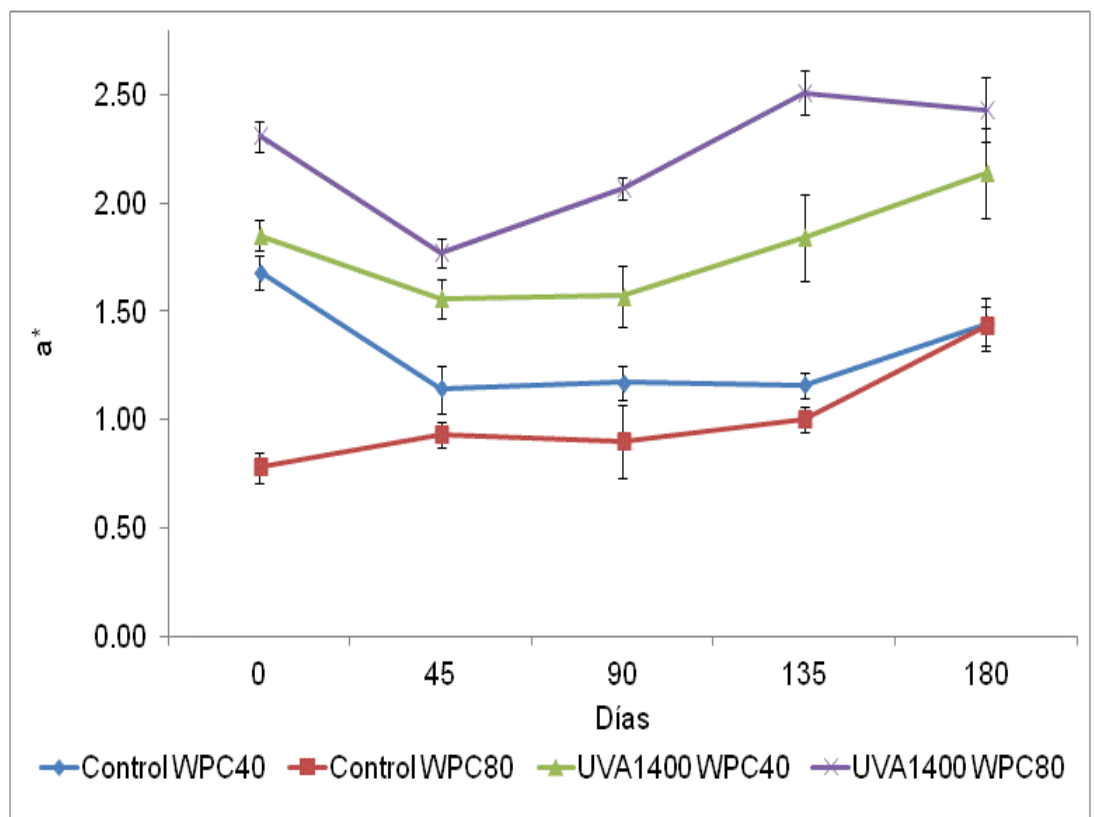

Figura VII- 25: : Valores de $\mathrm{a}^{*}$ interno de las formulaciones de saraca cocidas. . *Valores promedio \pm error standard de la media $(n=8)$. 
El valor $b^{*}$ presentó el mismo comportamiento entre las formulaciones. No se observó un efecto significativo debido al uso del antioxidante (Figura VII - 27). Se observó un descenso significativo entre el tiempo 0 y los 45 días, llevando el valor de b* de $13.08 \pm 0.55$ a $9.96 \pm 0.76$. Posterior este parámetro aumentó hasta los 135 días, siendo la muestra control WPC80 la única formulación que se diferenció significativamente de las otras formulaciones en relación al parámetro b* a los 135 días de almacenamiento. Luego de los 135 días se observó un descenso significativo alcanzando los valores iniciales $(12.56 \pm 0.63)$ para el parámetro de $b^{*}$

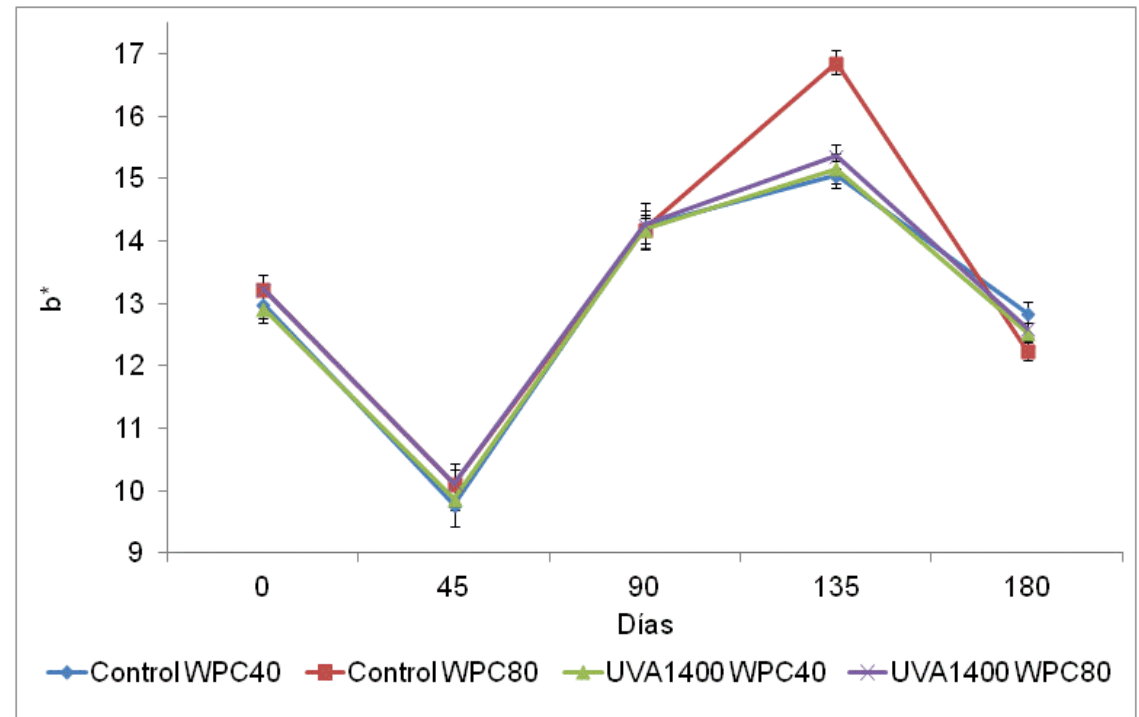

Figura VII- 26: Valores de $b^{*}$ interno de las formulaciones de saraca cocidas. *Valores promedio \pm error standard de la media $(n=8)$.

\section{Microbiología}

La calidad microbiológica de los conformados de saraca se analizó al inicio y al final del almacenamiento congelado. La determinación se realizó en los productos crudos. Según ICMSF (1986), una buena calidad microbiológica en pescado para consumo no debe superar un recuento de mesófilos totales en PCA de 7 log UFC/g. En este trabajo, no se observó al inicio del almacenamiento diferencias significativas en los recuentos microbiológicos de mesófilos totales, Enterobacteriaceae, hongos y levaduras entre las 4 formulaciones $(P<0.01)$. El recuento de mesófilos totales presentó valores entre $4.9 \pm 0.5$ y $5.6 \pm 0.21 \mathrm{log} \mathrm{UFC} / \mathrm{g}$, Enterobacteriaceae entre 3.13 \pm 0.48 y $3.87 \pm 0.65 \mathrm{log}$ UFC/g, hongos y levaduras entre $4.44 \pm 0.35$ y $4.68 \pm 0.38 \log$ UFC/g (Figura VII - 28). Si bien los recuentos de mesófilos totales fueron menores al límite de 7 log UFC/g fueron elevados, esto se debió al tiempo transcurrido entre la captura, el transporte desde la bahía de Samborombón a Mar del Plata, y las 
diferentes etapas del procesamiento para obtener las hamburguesas, por lo cual el pescado se procesó durante las 48 hs posteriores a la captura. Si bien se almacenó en cámara de fresco con abundante hielo, los microorganismos continuaron su desarrollo. Valores similares fueron reportados por Sallam y col. (2007) en músculo de salmón con 3 días de almacenamiento refrigerado (mesófilos totales 5 log UFC/g y Enterobacteriaceae 2.5 log UFC/g) y por otro lado López-Caballero y col. (2005) informaron recuentos de mesófilos totales de $4.2 \mathrm{log}$ UFC/g en filete de bacalao y definió a este valor como un rango normal presente en pescado procesado para la obtención de filete. Con respecto a las bacterias psicrófilas no se observaron diferencias significativas debidas al uso de antioxidante ni al WPC utilizado. Se observaron diferencias significativas debidas a las interacciones dobles (antioxidante $\mathrm{x}$ WPC y antioxidante $x$ tiempo). La muestra Control WPC80 al inicio del almacenamiento presentó un recuento menor de $4.00 \pm 0.02 \log$ UFC/g, sin presentar diferencias significativas con la muestra Control WPC40 (4.15 \pm 0.15$)$, pero si significativo con las formulaciones UVA1400 WPC40 y UVA1400 WPC80 (4.42 \pm 0.24 y $4.43 \pm 0.25$, respectivamente). Esta menor carga de bacterias psicrófilas en las formulaciones Control WPC80 Y WPC40, podría deberse a que las mismas fueron desarrolladas en orden, procesándose primeramente las formulaciones Control y luego las formulaciones con extracto de uva, demorando aproximadamente 2.5 hs desarrollar y moldear cada tanda de hamburguesas. Valores similares en el recuento de psicrófilas (3.95 log CFU/g) fueron reportados en Pacific saury (Cololabis saira) por Sallam y col. (2007).

En las cuatro formulaciones se encontró una reducción significativa de los diferentes recuentos microbianos durante el almacenamiento congelado (Figura VII 29). Al sexto mes de almacenamiento no se observaron diferencias significativas en los recuentos de mesófilos totales, Enterobacteriaceae, hongos y levaduras. El recuento de bacterias mesófilas totales presentó una reducción entre el $15.14 \%$ (Control WPC40) y $27.63 \%$ (Control WPC80), las Enterobacteriaceae entre el $38.63 \%$ (UVA1400 WPC40) y $66.68 \%$ (UVA1400 WPC80) y hongos y levaduras entre $26.34 \%$ (Control WPC40) y $34.61 \%$ (UVA1400 WPC40). En relación a las bacterias psicrófilas, se observaron diferencias significativas entre las formulaciones al sexto mes de almacenamiento. Las muestras control presentaron menores recuentos que las formulaciones con extracto de semilla de uva. También presentaron reducciones significativas y variaron entre $9.56 \%$ (UVA1400 WPC80) y $23.51 \%$ (Control WPC40). 


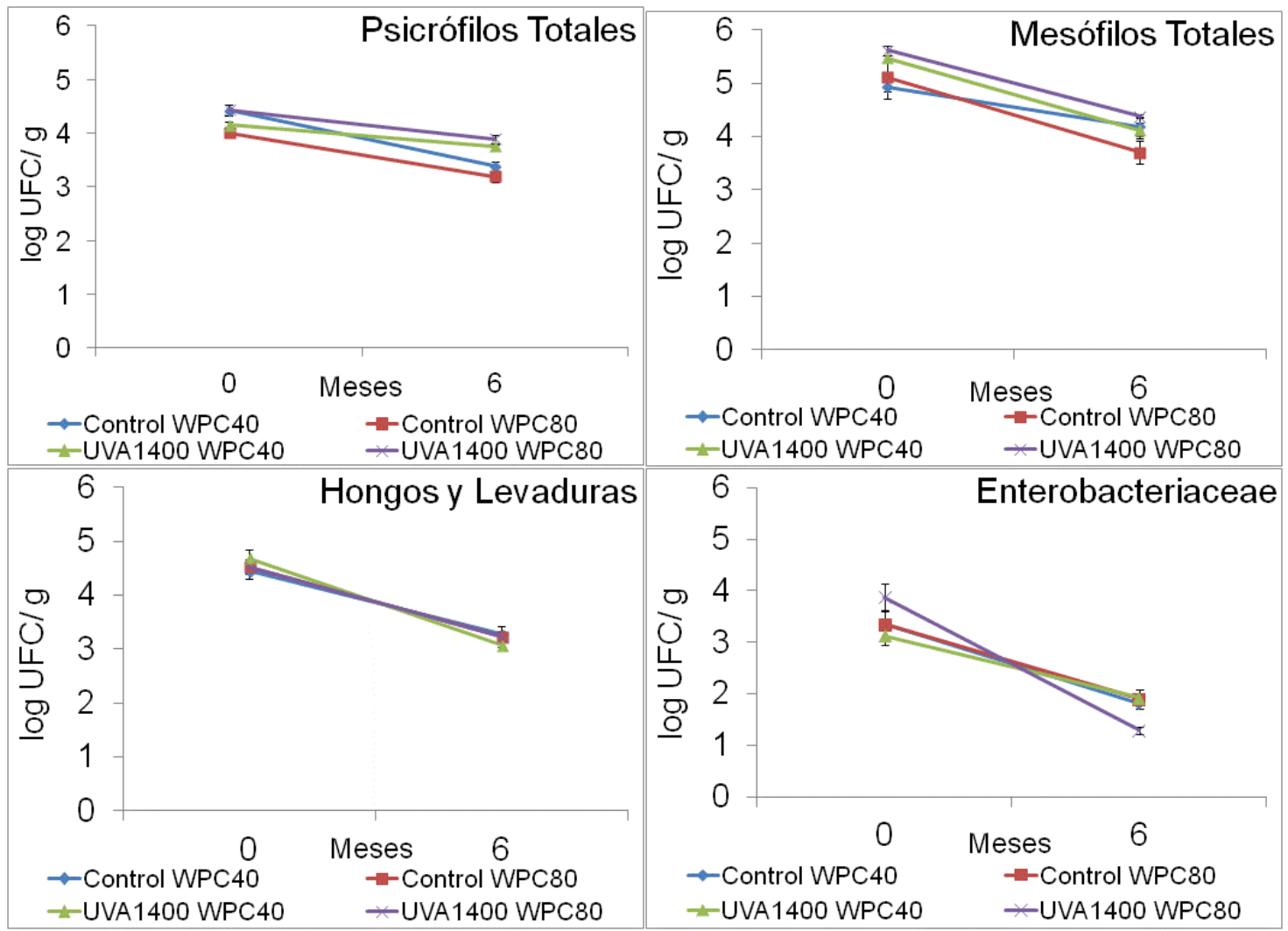

Figura VII- 27: Recuento de microorganismos (mesófilos totales, psicrófilos totales, Enterobacteriaceae, hongos y levaduras) en las hamburguesas de saraca almacenadas congeladas a $-25^{\circ} \mathrm{C}$ durante 6 meses.

\section{Ensayo de aceptabilidad por consumidores}

Los resultados del ensayo de aceptabilidad con consumidores, de las formulaciones con ambos ligantes y antioxidante UVA1400, se presentan en la Tabla VII - 9. Se analizó el puntaje medio para cada atributo sensorial y la aceptación general. A su vez se determinó el porcentaje de los consumidores que marcó en la escala hedónica valores mayores a 5 , valor a partir del cual se considera que al consumidor le gusta un atributo o producto. Se determinó que al $70 \%$ de los panelistas les gustó el olor, sabor, textura, aceptabilidad de la formulación con WPC40 y el color en un $82.5 \%$. El producto formulado con WPC80, tuvo una aceptación mayor, en todos los parámetros evaluados, que la formulación con WPC40. Entre el $87.5 \%$ y $92.5 \%$ de los panelistas les gustó el olor, color, textura y la aceptabilidad general y al $82.5 \%$ de los consumidores les gustó el sabor de la formulación con WPC80. Sin embargo el ensayo comparativo de medias arrojó que no existieron diferencias significativas entre los puntajes de los parámetros de olor, sabor, color y textura $(P>0.05)$ entre las dos formulaciones analizadas. Por otro lado se observó diferencia significativa en relación a la aceptabilidad general presentándose una 
preferencia de los consumidores por la formulación UVA1400 WPC80. El color de ambas formulaciones fue el parámetro que recibió mayor puntuación, si bien no presentaron diferencias significativas el color de la formulación WPC80 presentó un 10 \% más de aceptación de los panelistas que la formulación WPC40. Con respecto al sabor, se observó una puntuación de $6.39 \pm 0.44$ para la formulación con WPC40 mientras la formulación UVA140 WPC80 presentó un puntaje de $7.30 \pm 0.30$. Una puntuación similar se observó en relación al parámetro olor con valores medios de puntuación $6.37 \pm 0.38$ en la formula WPC40 y $7.32 \pm 0.27$ en la formula WPC80. En el caso particular de la textura se observó que el $27.5 \%$ de los consumidores no les gustó la textura de la formulación con WPC40 mientras que en el caso de WPC80 sólo el $7.5 \%$ no gustó de la misma. Estos resultados de aceptación coinciden con lo encontrado por El-Magoli, Laroiab y Hansed, (1996) en el análisis sensorial de hamburguesas de carne con distintos porcentajes de WPC, que demostró que a mayor porcentaje de proteínas de suero mejor resultaba el sabor del producto. Este aumento del sabor está asociado a las proteínas del suero de la leche y al contenido de lactosa presente en el concentrado de proteínas de suero lácteo. La lactosa es un potencial resaltador del sabor para productos cárnicos. En concentraciones menores a $1.2 \%$ mejora el sabor sin dar sensación dulce y a concentraciones superiores produce un sabor dulce indeseable en este tipo de productos. En este trabajo, el contenido de lactosa presente en las formulaciones con WPC40 fue 1.6\%, superior al propuesto como límite por El-Magoli, Laroiab y Hansed, (1996). El contenido de lactosa podría explicar la menor aceptación del sabor en estas formulaciones que aquellas que contenían WPC80. Este efecto sobre el sabor se atribuye a las reacciones de pardeamiento no enzimático, donde se producen compuestos volátiles. El efecto de la lactosa como resaltador del sabor en productos cárnicos fue reportado también por otros autores como Van den Hoven (1987) y Faustman y Cassens (1990).

Tabla VII- 6: Valores medios de propiedades sensoriales de hamburguesas de saraca.

\begin{tabular}{lllllllll}
\hline Formulación & Olor & Sabor & Color & \multicolumn{2}{l}{ Textura } & \multicolumn{2}{c}{ Aceptabilidad } \\
\hline UVA1400 & $6.37 \pm 0.38$ & $6.39 \pm 0.44$ & $6.94 \pm$ & 0.32 & $6.65 \pm 0.35$ & 6.42 & \pm & 0.34 \\
WPC40 & $(70 \%)$ & $(70 \%)$ & $(82.5 \%)$ & $(70 \%)$ & $(70 \%)$ & \\
UVA1400 & $7.32 \pm 0.27$ & $7.30 \pm 0.30$ & $7.48 \pm 0.29$ & $7.20 \pm 0.29$ & 7.35 & \pm & 0.27 \\
WPC80 & $(87.5 \%)$ & $(82.5 \%)$ & $(92.5 \%)$ & $(87.5 \%)$ & $(90 \%)$ &
\end{tabular}

${ }^{*}$ El porcentaje de panelistas que evaluaron la propiedad con un valor $>5$ en la escala hedónica es dado entre paréntesis. 


\section{VII.4. CONCLUSIONES}

Se desarrolló un producto pesquero saludable, seguro y de buena calidad, con alto contenido de n-3 y enriquecido con n-9 y fitoesteroles.

El agregado del antioxidante natural de extracto de semillas de uva en la dosis de 1400 ppm presentó una buena efectividad contra la oxidación lipídica. Mientras que la dosis de 700 ppm fue menos efectiva. La dosis mayor de extracto de semillas de uva tuvo un efecto comparable a la del antioxidante sintético utilizado industrialmente, constatándose que la utilización del extracto de uva es adecuada para este tipo de producto.

En relación al efecto del tipo de suero de leche independientemente de los otros factores evaluados se observó que las hamburguesas de saracas formuladas con WPC40 presentaron una menor oxidación, mayor capacidad de retener lípidos y mayor contenido de EPA y DHA en el perfil de ácidos grasos de los lípidos retenidos; asimismo, el producto cocido presentó una menor dureza que las muestras con WPC80. Mientras que el uso de suero con mayor contenido de proteína (WPC80) produjo mayores rendimientos en las formulaciones luego de la cocción, mayor retención de agua, menor reducción del tamaño, mayor dureza, mayor masticabilidad y mayor blancura interna que el uso del WPC40. Ambos sueros de leche presentaron características deseables en el producto propuesto. El color interno y externo correspondió a valores adecuados de los parámetros $L^{*} y a^{*}$. Por otro lado no se observó diferencias en la jugosidad al variar el WPC en las formulaciones, pero a diferencia de lo esperado, la utilización del antioxidante retuvó una mayor jugosidad que las muestras control.

Los perfiles de ácidos grasos de los productos cocidos mostraron un elevado contenido en ácido oleico (40 -45\%) y niveles de ácidos grasos EPA + DHA entre 11.5 y 13.5\%; el consumo de 100 gramos de cualquiera de las formulaciones aportarían la dosis recomendada de EPA + DHA de 1000mg/día y $200 \mathrm{kcal}$.

La calidad microbiológica de los productos crudos fue adecuada (recuentos $<5.5$ logUFC/g) durante los 6 meses de almacenamiento, demostrando buenas condiciones sanitarias de su elaboración.

Los resultados obtenidos del análisis sensorial con consumidores no arrojaron diferencias significativas entre las formulaciones con WPC40 y WPC80 para los atributos principales de color, olor, sabor y textura. Se observó que a más del $70 \%$ de los panelistas les gustaron los atributos principales de los productos con ambos concentrados proteicos.

Si bien en la aceptabilidad general el WPC80 presentó una aceptabilidad levemente mayor que el producto con WPC40, por todas las características 
observadas durante el desarrollo de este Capítulo, donde el WPC40 también presentó buenas propiedades tecnológicas; se podría proponer el uso del WPC40 en un producto pesquero como el diseñado en esta Tesis. De esta manera se fomenta la utilización del WPC producido en el país frente al importado en la producción de un alimento rico, nutritivo y sano, con beneficios para la salud, utilizando insumos nacionales, sustituyendo el uso de antioxidante sintético por uno natural como es el extracto de semillas de uva y aprovechando como materia prima la carne de saraca que actualmente se descarta. 


\section{CAPITULO VIII \\ CONCLUSIONES}

La especie Brevoortia aurea, presenta marcados cambios en su ciclo biológico, los cuales se ven reflejados en los índices morfométricos y en los cambios químicos de la composición proximal del músculo, principalmente en el contenido de lípidos y humedad. Cuando la especie se encuentra biológicamente en reposo, sus órganos sexuales no se encuentran desarrollando ovocitos ni espermatocitos. A su vez concuerda con un periodo de florecimiento algal, brindando abundancia en alimento para la saraca. El gasto energético destinado a los cambios fisiológicos es menor, por lo cual los lípidos son acumulados en el músculo alcanzando el valor máximo de $20 \%$ y mientras que el contenido de humedad llega a valores mínimo (63\%). Esta acumulación de energía luego la destinará para la etapa de migración, maduración gonadal y desove.

Por otro lado, la época de desove concuerda con un periodo de menor alimentación y mayor desgaste fisiológico abarcando los meses desde septiembreoctubre a diciembre-enero. A medida que la especie comienza a desarrollar sus órganos sexuales y se prepara para la época de puesta, el contenido de lípidos en músculo disminuye hasta el $3 \%$, mientras que la humedad aumenta significativamente hasta alcanzar valores de $78 \%$; el contenido de proteínas y ceniza no varía significativamente a lo largo del ciclo.

Con respecto al perfil de los ácidos grasos, la saraca presenta un alto contenido de ácidos grasos poli-insaturados, especialmente docosahexaenoico (DHA), eicosapentaenoico (EPA) y oleico a lo largo del ciclo biológico, siendo mayor el porcentaje cuando menor es el contenido de lípidos total.

El almacenamiento congelado a $-25^{\circ} \mathrm{C}$, provocó alteraciones en el músculo desmenuzado de saraca por la desnaturalización de las proteínas, influyendo en sus propiedades funcionales y la estabilidad de las mismas. Esto se evidenció por una disminución del cambio entálpico total correspondiente a esta transición, a medida que aumentó el tiempo de almacenamiento y tecnológicamente se vio reflejada, en la disminución de la capacidad de retención de agua (WHC) y en el aumento de las pérdidas por drip tanto en los desmenuzados de julio como de diciembre. Las imágenes obtenidas con el microscopio electrónico de barrido mostraron cambios en la estructura, disposición e interacción de las fibras musculares. Al final del almacenamiento se observaron estructuras de agregación entre fibras musculares que explicarían en cierta medida las pérdidas en la funcionalidad de las proteínas en 
relación al WHC y al drip. En cambio, el índice de actividad de la emulsión no varió a lo largo del almacenamiento congelado de las muestras de diciembre y julio. Indicando que las muestras, a pesar de presentar desnaturalización, son estables para formar emulsiones a lo largo del almacenamiento congelado.

La adición del extracto de semillas de uva, utilizado como antioxidante natural, presentó una buena actividad como inhibidor de la oxidación lipídica en el desmenuzado de músculo de saraca almacenado congelado a $-25^{\circ} \mathrm{C}$ durante al menos 6 meses. Es conveniente considerar que dado los elevados valores iniciales de TBARS correspondientes al mes de diciembre, durante el periodo de verano, se deberían tomar mayores cuidados por parte de la flota costera y mejorar las condiciones de almacenamiento inmediatamente después de la captura. Bajando convenientemente la temperatura a bordo, los antioxidantes naturales ensayados durante el almacenamiento del músculo congelado, deberían dar resultados tan buenos como en el desmenuzado realizado con ejemplares en el mes de julio, donde los valores de TBARS se mantuvieron por debajo de los $2 \mathrm{mg} / 100 \mathrm{~g}$ músculo pese a que el contenido de lípidos era casi 10 veces mayor.

Referente a la calidad higiénico-sanitaria de la materia prima, en el desmenuzado de saraca almacenado congelado se observó un aumento significativo en el valor de nitrógeno básico volátil total a lo largo del tiempo. Los valores iniciales de NBVT correspondientes al desmenuzado de diciembre fueron elevados, y mayores que los de julio, pero ambos aumentaron durante todo el almacenamiento. Durante los meses de altas temperaturas se observa valores de NBVT mayores, asociado a la falta de refrigeración desde la captura hasta el desembarque. El desmenuzado de diciembre presentó al sexto mes valores de NBVT superiores al límite establecido por CAA y SENASA (30 mg NBVT / $100 \mathrm{~g}$ de músculo) por lo que sería indispensable almacenar a bajas temperaturas el pescado inmediatamente después de su captura.

Con respecto a la histamina, no se la detectó en ninguna de las muestras analizadas, pese a que los altos valores de NBVT correspondientes al pescado de diciembre indicaría que las muestras estuvieron expuestas a altas temperaturas. Esto permite inferir que la saraca no es una especie rica en histidina formadora de la histamina.

Los recuentos microbiológicos estuvieron dentro de los límites establecidos, (menores a $10^{7}$ UFC/g de músculo para las bacterias psicrótrofas). Las muestras de diciembre presentaron recuentos superiores a las de julio. Se observó una reducción de los recuentos microbianos al avanzar el tiempo de almacenamiento congelado a $25^{\circ} \mathrm{C}$. 
La técnica desarrollada para evaluar el contenido de espinas utilizando una enzima proteolítica presentó buena reproducibilidad y valores de recuperación elevados, siendo su ejecución simple. Es un método sencillo para cuantificar y clasificar las espinas presentes en el desmenuzado y de esta manera determinar uno de los riesgos físicos que hacen a la calidad higiénico sanitaria del mismo. El tamaño, forma y rigidez de las espinas enteras de saraca son largas, son finas y flexibles por lo que no presentan riesgo de ahogo para los consumidores.

Las saracas analizadas se encontraban libres de parasito por lo cual se puede considerar como una especie que no presenta un riesgo de infestación parasitaria.

A partir de los resultados observados durante el ciclo biológico y el almacenamiento congelado del desmenuzado de saraca, se podría pensar en incluir a la saraca como materia prima segura y de excelente calidad nutricional, rica en ácidos grasos poli-insaturados, para desarrollar nuevos productos saludables, ampliar el mercado y obtener una mayor rentabilidad de los productos realizados con esta materia prima que actualmente es descartada.

Se diseñó una hamburguesa de saraca con la adición de proteínas de suero lácteo controlando la oxidación lipídica mediante el uso de antioxidantes naturales, con buena retención de agua y lípidos y adecuada textura del producto cocido. El agregado del antioxidante natural de extracto de semillas de uva en la dosis de 1400 ppm presentó una buena efectividad contra la oxidación lipídica del producto. Comparable con los antioxidantes sintéticos utilizados en la industria. Mientras que en la dosis de 700 ppm en el producto fue menos efectivo.

Las hamburguesas de saraca formuladas con WPC40 presentaron buenos resultados frente a la oxidación, buena capacidad de retener lípidos, alto contenido de EPA y DHA y una dureza menor, comparado con las hamburguesas formuladas con WPC 80. Por otro lado, la utilización del WPC80 mejoró los rendimientos luego de la cocción, disminuyó la reducción del tamaño, retuvo más agua luego de la cocción, y presentó mayor dureza y masticabilidad. Ambos sueros de leche presentaron por separado características deseables en el producto propuesto, sin presentar diferencias sobre la jugosidad. El color interno y externo correspondió a valores adecuados de los parámetros $L^{*}$ y $a^{*}$.

Nutricionalmente el producto aportaría un elevado contenido en ácido oleico (40 $45 \%$ ), ácidos grasos EPA + DHA entre 11.5 y $13.5 \%$ y además fitoesteroles. El consumo de 100 gramos de cualquiera de las formulaciones aportarían la dosis recomendada de EPA + DHA de 1000mg/día (AHA, 2010) y solamente $200 \mathrm{kcal}$.

El ensayo de análisis sensorial con consumidores no detectó diferencias significativas entre las formulaciones con WPC40 y WPC80 para los atributos 
principales de color, olor, sabor y textura. Sin embargo el WPC80 presentó una aceptabilidad levemente mayor que el producto con WPC40. Por todas las características observadas en el desarrollo de este producto, si bien ambos sueros de leche presentaron buenas propiedades tecnológicas, se podría proponer el uso del WPC40, de fabricación nacional como una muy buena alternativa para su uso de productos pesqueros como el diseñado en esta Tesis.

En este trabajo de Tesis doctoral se cumplió, entonces, con el desarrollo de un producto saludable, seguro y de buena calidad, con alto contenido de $n-3$, y con buenas características sensoriales, aprovechando como materia prima la carne de saraca que actualmente se descarta. 


\section{Bibliografía}

- ACHA, E.M. (1999). Estrategia reproductiva de la saraca, Brazilian menhaden, Brevoortia aurea (Pisces: Clupeidae), en el estuario del Río de la Plata. Tesis (Doctorado) Mar del Plata, pág 174, Biblioteca INIDEP.

- ACHA, E.M. Y MACCHI, G.J. (2000). Spawning of Brazilian menhaden, Brevoortia aurea, in the Río de la Plata estuary off Argentina and Uruguay. Fishery Bulletin, 98:227-235.

- ADKINS, Y. Y KELLEY, D. (2010). Mechanisms underlyung the cardioprotective effects of omega-3 polyunsaturated fatty acids. Journal of Nutritional Biochemistry, 21 : 781-792.

- AHA (Asociación Americana del Corazón). (2006). Aprenda y viva más, conozca su corazón. [online]. [citado octubre 2009]. Disponible en: http://www.americanheart.org/downloadable/heart/1165854028272CSC_Nuticion_Repr os.pdf .

- AHA (Asociación Americana del Corazón). (2010). Frequently Asked Questions About Fish. [online]. [citado septiembre 2013]. Disponible en: http://www.heart.org/HEARTORG/General/Frequently-Asked-Questions-About-

Fish_UCM_306451_Article.jsp

- ALGHAZEER, R.; SAEED, S. Y HOWELL, N.K. (2008). Aldehyde formation in frozen mackerel (Scomber scombrus) in the presence and absence of instant green tea. Food Chemistry, 108: 801-810.

- AMUNDSEN, A.G.; OXE, L.; NENSETER, M.S. Y NTANIOS, F. (2002). Plant sterol enriched spread lowers plasma total and LDL-cholesterol in children with familial hypercholesterolemia. American Journal Clinical Nutrition, 76: 338-344.

- ANDRÉS, S.C.; PENNISI FORELL, S.C.; RANALLI, N.; ZARITZKY, N.E. Y CALIFANO, A.N. (2011). Healthier functional beef burgers. En: Agricultural Research Updates - Ed Hendriks, B. Nova Science Publishers, Inc. Chapter. Estados Unidos.

- ANDRÉS, S.C.; ZARITZKY, N.E. Y CALIFANO, A. N. (2009). Innovations in the development of healthier chicken sausages formulated with different lipid sources. Poultry Science, 88: 1755-1764.

- ANESE, M. Y GORMLEY, R. (1996). Effects of dairy ingredients on some chemical, physico-chemical and functional properties of minced fish during freezing and frozen storage. LWT - Food Science and Technology, 29: 151-157.

- AOAC (ASSOCIATION OF OFFICIAL ANALYTICAL CHEMISTS). (1984). Official Methods of Analysis ( $14^{\text {th }}$ ed.). Washington, DC. Estados Unidos. 
- BABBITT, J. K. (1986). Suitability of seafood species as raw materials. Food Technology, 40:97- 100.

- BALEV, D.; IVANOV, G.; NIKOLOV H. Y DRAGOEV, ST. (2009). Effect of pretreatment with natural antioxidants on the color surface properties of chilled-stored salmon discs. Bulgarian Journal of Agricultural Science, 15: 379-385

- BARON, C.P.; KJÆERSG̊̊RD, I.V.H.; JESSEN F. Y JACOBSEN, C. (2007). Protein and lipid oxidation during frozen storage of rainbow trout (Oncorhynchus mykiss). Journal of Agriculture Food Chemistry, 55: 8118-8125.

- BERTOLOTTI, M.I. (2010). "El mercado interno de productos pesqueros marinos enfriados: puerto de mar del plata, principal proveedor", Informe investigación 05/2010 INIDEP, Mar del Plata, Argentina.

- BORDERIAS, A.J.; JIMENEZ-COlMENERO, F. Y TEJADA, M. (1985). Viscosity and emulsifying ability of fish and chicken muscle protein. Journal of Food Technology, 20:31-42.

- BORDERIAS, A.J. Y PERÉZ-MATEOS, M. (1996). Productos pesqueros reestructurados. Alimentaria, 269: 53-62. BOURNE, M.C. (2002). Principles of objective texture measurement. En: Food texture and viscosity: Concept and measurement. Bourne, M.C. (Ed.), Academic Press (107-188). Londres.

- BREWER, M.S. (2011). Natural Antioxidants: Sources, Compounds, Mechanisms of Action, and Potential Applications. Comprehensive Reviews in Food Science and Food Safety, 10: 221-247.

- BRITOS, S.; CLACHEO, R.; GRIPPO, B.; O’DONNELL, A.; PUEYRREDÓN P.; PUJATO D.; ROVIROSA, A. Y UICICH, R. (2004). Obesidad en Argentina: ¿Hacia un nuevo fenotipo? Boletín Cesni. [online]. [citado septiembre 2009]. Disponible en: http://www.nutrinfo.com/pagina/info/ob05-01.pdf?PHPSESS= c8b364fa45deee58fb2a370d83372f39.

- BURGAARD, M. G. Y JORGENSEN, B. M. (2010). Effect of temperature on quality-related changes in cod (Gadus morhua) during short- and long-term frozen storage. Journal of Aquatic Food Product Technology, 19: 249-263.

- CAA (CÓdigo Alimentario ARgEnTINO). (2005). Capítulo VI, Alimentos Cárneos y Afines. [online]. [citado diciembre 2011]. Disponible en: www.anmat.gov.ar/codigoa/caa1.htm

- CALVO, P. (2004). La desnutrición oculta, nuevo disfraz del hambre. [online]. [citado octubre 2008]. Disponible en: http://www.si.clarin.com.ar/suplementos/zona/2004/08/01/z-03416.htm 
- CAMPBELL, R.E. (2010). Impact of annatto colorant, different starter cultures, starter media and starter strains on the flavor and oxidative stability of liquid whey and WPC. Tesis. Universidad Estatal de Carolina del Norte.

- CANDOGAN, K. Y KOLSARICI, N. (2003). Storage stability of low-fat beef frankfurters formulated with carrageenan or carrageenan with pectin. Meat Science, 64: 207-214.

- CARVAlHO, R.N.; MOURA, L.S.; ROSA, P.T.V. Y MEIRELES, M.A.A. (2005). Supercritical fluid extraction from rosemary (Rosmarus officinalis): kinetic data, extracts global yield, composition, and antioxidant activity. Journal of Supercritical Fluids, 35:197-204.

- CHAIJAN, M.; BENJAKUL, S.; VISESSANGUAN, W. Y FAUSTMAN, C. (2005) Changes of pigments and color in sardine (Sardinella gibbosa) and mackerel (Rastrelliger kanagurta) muscle during iced storage. Food Chemistry, 93: 607- 617.

- CHAN, W.K.M.; FAUSTMAN, C.; YIN, M. Y DECKER, E.A. (1997). Lipid oxidation induced by oxymyoglobin and metmyoglobin with involvement of $\mathrm{H}_{2} \mathrm{O}_{2}$ and superoxide anion. Meat Science, 46: 181-190.

- CHEFTEL, J.C Y CHEFTEL. (1976). Introducción a la Bioquímica y Tecnología de los Alimentos. Ed. Acribia, Zaragoza. España. Vol I. Capítulo II y III 65-68, pp. 239247.

- CHOW, K.C. (2000). Fatty Acids in Foods and their Health Implications, 2nd ed. Marcel Dekker, Inc., New York, Estados Unidos.

- CHRISTENSEN, L.M. (2012). Evaluation of textural properties of cooked beef batters. Tesis Universidad Politécnica de California.

- ClARET, A.; GUERRERO, L.; AGUIRRE, E.; RINCON, L.; HERNANDEZ, M.D.; MARTINEZ, I.; PELETERIO, J.B.; GRAU, A. Y RODRIGUEZ-RODRIGUEZ, C. (2012). Consumer preferences for sea fish using conjoint analysis: Exploratory study of the importance of country of origin, obtaining method, storage conditions and purchasing price. Food Quality and Preference, 26: 259-266.

- COLLINS, A.L. Y ANDERSON, T.A. (1995). The regulation of endogenous energy stores during starvation and refeeding in the somatic tissues of the golden perch. Journal of Fish Biology, 47:1004-1015.

- COlOMBO, J.; CARLSON, S.; CHEATHAM, C.; SHADDY, L; KERLING, E.; THODOSOFF, J. GUSTAFSON, K. Y BREZ, C. (2013). Long-term effects of LCPUFA supplementation on childhood cognitive outcomes. American Journal of Clinical Nutrition, 98: 403-412 
- CONDE PIÑEIRO, E. (2009). Revalorización de residuos agroindustriales y forestales para la obtención de antioxidantes naturales con aplicaciones en la industria alimentaria, cosmética y/o farmacéutica. Tesis Universidad de Vigo.

- CONNELL, J.J. (1995). Control of fish quality. 4Ed. Fishing News Books, Farnham, Surrey, Inglaterra.

- CONNOR, W.E. (2000). Importance of n-3 fatty acids in health and disease. American Journal Clinical Nutrition, 71: 171S-175S.

- CONTRERAS-GUZMAN, E. (2002). "Bioquímica de Pescados e Invertebrados". CECTA USACH (Ed.), Santiago, Chile.

- COUSSEAU, M. Y PERROTA, R. (2000). "Peces marinos de Argentina, biología, distribución, pesca”. INIDEP, Mar del Plata, 167 pág.

- DALGAARD, P. (1993). Evaluation and prediction of microbial fish spoilage. Tesis. The Technological Laboratory of the Danish Ministry of Fisheries and the Royal Veterinary and Agricultural University, Dinamarca.

- DALGAARD, P.; GRAM, L. Y HUSS, H.H. (1993). Spoilage and shelf-life of cod fillets packed in vacuum or modified atmospheres. International Journal of Food Microbiology, 19: 283-294

- DAMECHKI, M.; SOTIROPOULOU, S. Y TSIMIDOU, M. (2001). Antioxidant and pro-oxidant factors in oregano and rosemary gourmet olive oils. Grasas y Aceites. 52: 207-213.

- DE CATERINA, R.; LIAO, J.K. Y LIBBY, P. (2000). Fatty acid modulation of endothelial activation. The American Journal of Clinical Nutrition, 71: 213-223.

- DE CATERINA, R. (2011). n-3 Fatty Acids in Cardiovascular Disease. The New England Journal of Medicine, 364: 2439-2450.

- DE GRAAF, J.; DE SAUVAGE NOLTING, P.R.W.; VAN DAM, M.; BELSEY, E.M, KASTELEIN, J.J.P., PRITCHARD P.H. y STALENHOEF, A.F.H. (2002). Consumption of tall oil-derived phytosterols in a chocolate matrix significantly decreases plasma total and low-density lipoprotein-cholesterol levels. British Journal of Nutrition. 88: 479-484.

- DE SOUSA, V. Y BYAN, M. (1991). Las aminas biógenas como medida de la calidad de productos pesqueros. Alimentaria, 2: $51-58$.

- DE WIT, J. N. (1998). Nutritional and functional characteristics of whey proteins in food products. Journal of Dairy Science, 81:597-608.

- DICHRISTINA, T. Y DELONG, E. (1994). Isolation of anaerobic respiratory mutants of Shewanella putrefaciens and genetic analysis of mutants deficient in anaerobic growth on $\mathrm{Fe}^{3+}$. Journal of Bacteriology, 176: 1464-1474. 
- DONGDONG, L. (1994). Characteristics of Northern Squawfish (Ptychocheilus oregonensis) and Feasibility for Utilization as Human Food. Tesis Maestría en Ciencia y Tecnología de los Alimentos. Universidad Estatal de Oregon.

- EIDE, O.; BORRESEN, T.; Y STROM, T. (1982). Minced fish production from capelin (Mallotus villosus). A new method for gutting, skinning and removal of fat from small fatty fish species. Journal of Food Science, 47: 347 - 354.

- ELLIS, C. Y SILVA, M. (1997). Statistical classification of seafood quality. Journal of AOAC International, 80:1347-1359.

- EL-MAGOLI, S.B., LAROIAB S. Y HANSED, P.M.T. (1996). Flavor and texture characteristics of low fat ground beef patties formulated with whey protein concentrate. Meat Science, 42: 179-193.

- ENCINA, L. Y GRANADO-LORENCIO, C. (1997). Seasonal variation in the physiological status and energy content of somatic and reproductive tissues of chub. Journal of Fish Biology, 50: 511-522.

- ENFR (2011). Segunda encuesta nacional de factores de riesgo para enfermedades no transmisibles. Ministerio de Salud de la Nación. [online]. [citado agosto 2013]. Disponible en: http://www.msal.gov.ar/ent/images/stories/vigilancia/pdf/fr_encuesta-nacional-factoresriesgo-2011.pdf

- eRRAZTI, E.; BeRTOlOtTI, M.I.; PAGANI, A. Y GUALDONI, P. (2004). Característica del consumo de productos pesqueros de los residentes y turistas de Mar del Plata. FACES 10, 20:7-26.

- escuRRIOL, V.; COFÁN, M.; MORENO-IRIBAS, C.; LARRAÑAGA, N.; SÁNCHEZ, M.J.; NAVARRO, C.; QUIRÓS, J.R.; GONZALEZ, C.; CORELLA, D. Y ROS, E. (2009). Fitoesteroles plasmáticos: marcadores de una dieta saludable y un riesgo cardiometabólico menor en la población española del estudio EPIC. Clínica e Investigación en Arteriosclerosis, 21:106-114.

- ESTÉVEZ, M. Y CAVA, R. (2006). Effectiveness of rosemary essential oil as an inhibitor of lipid and protein oxidation: contradictory effects in different types of frankfurters. Meat Science, 72: 348-355.

- EUROPEAN COMMISSION. (2011). Obesidad, nutrición y actividad física. [online]. [citado diciembre 2012]. Disponible en: http://europa.eu/legislation_summaries/public_health/health_determinants_lifestyle/c11 542a_es.htm

- FAO (Food and Agriculture Organization of the United Nations). (1985). Histamine in marine products: production by bacteria, measurement and prediction of 
formation. Fisheries Technical Paper, no. 252 66pp. Pan, B.S. (ed.); James, D.G. (ed.) Italia.

- FAO (Food and Agriculture Organization of the United Nations). (1996).El Estado Mundial de la Pesca y la Acuicultura. [on line] [citado junio 2012]. Disponible en: http://www.fao.org/docrep/003/w3265s/w3265s02.htm .

- FAO (Food and Agriculture Organization of the United Nations). (1997). Grasas y aceites en la nutrición humana. 3. Consulta FAO/OMS de expertos. [on line] [citado noviembre 2009]. Disponible en: http://www.fao.org/docrep/V4700S/v4700s00.HTM.

- FAO (Food and Agriculture Organization of the United Nations). (2010). Organización de Naciones Unidas para la Agricultura y la Alimentación. [on line] [citado enero 2013]. Disponible en: http://www.rlc.fao.org/uploads/media/panorama10_03.pdf.

- FAO (Food and Agriculture Organization of the United Nations). (2011). Estadísticas de la pesca y la acuicultura, Anuario 2009. [on line] [citado enero 2013]. Disponible en: ftp://ftp.fao.org/FI/CDrom/CD_yearbook_2009/root/commodities/a1a.pdf

- FAO (Food and Agriculture Organization of the United Nations). (2013).Código de Conducta para la Pesca Responsable. [on line] [citado julio 2013]. Disponible en: http://www.fao.org/docrep/005/v9878s/v9878s00.htm

- FARKAS, J.K.; FLOROS, J.D.; LINEBACK, D.S. Y WATKINS, B.A. (1997). Oxidation kinetics of menhaden oil with TBHQ. Journal of Food Science, 62:505-507.

- FARKYE, N. (2004). Cheese technology. International Journal of Dairy Technology, 57:91-98.

- FAUSTMAN, C. Y CASSENS, R. (1990). The biochemical basis for discoloration in fresh meat: a review. Journal of Muscle Foods, 1: 217-243.

- FDA (FOOD AND DRUG ADMINISTRATION). (2000). Code of Federal Regulations [online]. [citado marzo 2012]. Disponible en: http://www.fda.gov/ora/compliance_ref/part11

- FDA (FOOD AND DRUG ADMINISTRATION) (2001). Potential Species Related \& Process-Related Hazards. In Fish and fisheries products hazards and controls guidance. 3rd Ed. Florida Sea Grant. Estados Unidos.

- FDA (FOOD AND DRUG ADMINISTRATION). (2004). Substances affirmed as generally recognized as safe: menhaden oil. Food and Drug Administration Federal Register, 69, 2313e2317

- FENNEMA, O.R. (1996). Lipids. En: Fennema, O.R. ed. Food Chemistry, 3ª . ed. Marcel Dekker. New York. pp.225-319.

- FIELD, R.A. (1988). Mechanically separated meat, poultry and fish. En: Edible meat by-products. Advances in Meat Research, 83-126. 
- FRANKEL, E.N. (1998). Lipid Oxidation. 1Th ed. The Oily Press: Dundee, Escocia. Inglaterra.

- FSIS (UNITED STATES DEPARTMENT OF AGRICULTURE FOOD SAFETY AND INSPECTION SERVICE WASHINGTON DC). (2007) Safe and suitable ingredients used in the production of meat and poultry products. [online]. [citado abril 2012].

http://www.fsis.usda.gov/About_FSIS/labeling_\&_consumer_protection/index.asp

- GARRIDO, I.; MONAGAS, M.; GÓMEZ-CORDOVÉS, C. Y BARTOLOMÉ, B. (2007). Extracción de antioxidantes a partir de subproductos del procesado de la almendra. Grasas y Aceites, 58: 130-135

- GELDOF, N. Y ENGESETH, N.J. (2002) Antioxidant capacity of honeys from various floral sources based on the determination of oxygen radical absorbance capacity and inhibition of in vitro lipoprotein oxidation in human serum samples. Journal of Agriculture Food Chemistry, 50:3050-3055.

- GeORGANTEliS, D.; BLEKAS, G.; KATIKOU, P.; AMBROSIADIS, I., Y FLETOURIS, D. (2007). Effect of rosemary extract, chitosan and a-tocopherol on lipid oxidation and colour stability during frozen storage of beef burgers. Meat Science, 75: 256-264.

- GILL, T.; KEITH, R. Y SMITH-LALL, B. (1979). Textural deterioration of red hake and haddock muscle in frozen storage as related to chemical parameters and changes in myofbrillar proteins. Journal of Food Science, 44: 661-667.

- GiMÉNEZ, B.; GÓMEZ-GUILLÉN, M.C.; PÉREZ-MATEOS, M.; MONTERO, P. Y MÁRQUEZ-RUIZ, G. (2011). Evaluation of lipid oxidation in horse mackerel patties covered with borage-containing film during frozen storage. Food Chemistry, 124: 13931403.

- GÓMEZ-ESTACA, J.; GIMÉNEZ, B.; GÓMEZ-GUILLÉN, C. Y MONTERO, P. (2010). Influence of frozen storage on aptitude of sardine and dolphinfish for coldsmoking process. Trends in Food Science and Technology, 43:1246-1252.

- GONÇALVES, A. A.; RECH, B. T.; DE MATTOS RODRIGUES; P. Y TEIXEIRA PUCCI, D. M. (2008). Quality evaluation of frozen seafood (Genypterus brasiliensis, Prionotus punctatus, Pleoticus muelleri and Perna perna) previously treated with phosphates. Pan-American Journal of Aquatic Sciences, 3: 248-258.

- GRAM, L.; WEDELL-NEERGAARD, C. Y HUSS, H.H. (1990). The bacteriology of spoiling Lake Victorian Nile perch (Lates niloticus). International Journal of Food Microbiology, 10: 303-316.

- GRAM, L. Y HUSS, H.H. (1996). Microbiological spoilage of fish and fish products. International Journal of Food Microbiology, 33: 121-137. 
- GRANADO LORENCIO, C. (2002). Estrategia de peces. En: Ecología de los peces. Ecología de peces. Universidad de Sevilla, Sevilla, España Pp.161-197.

- GRANTHAM, G. J. (1981). Minced fish technology: A review. FAO Fish. Tech. Paper No. 216: 72. Roma.

- GROSSO, G.; GALVANO, F.; MISTRETTA, A.; MARVENTANO, S.; NOLFO, F.; CALABRESE, G.; BUSCEMI, S.; DRAGO, F.; VERONESI, U. Y SCUDERI, A. (2013). Red Orange: Experimental Models and Epidemiological Evidence of Its Benefits on Human Health. Oxidative Medicine and Cellular Longevity, ID del artículo: 157240. [online]. [citado septiembre 2013]. Disponible en http://dx.doi.org/10.1155/2013/157240.

- GUNER, S.; DINCER, B.; ALEMDAG, N.; COLAK, A. Y TUFEKCI, M. (1998). Proximate and selected mineral content of commercially important fish species from the Black sea. Journal of the Science of Food and Agriculture, 78 : 337-342.

- HALE, M.E.; BAUERSFELD, P.E.; GALLOWAY, S.B. Y JOSEPH, J.D. (1991). New products and markets for Menhaden, Brevoortia spp. Marine Fisheries Review, 53: $42-48$.

- HAStings, R. J.; RODGER, G. W.; PARK, R.; MATTHEWS, A. D. Y ANDERSON E. M. (1985). Differential scanning calorimetry of fish muscle: The effect of processing and species variation. Journal of Food Science, 50: 503-510.

- HATZIDIMITRIOUA, E.; NENADISA, N. Y TSIMIDOU, M.Z. (2007). Changes in the catechin and epicatechin content of grape seeds on storage under different water activity (aw) conditions. Food Chemistry, 105:1504-1511.

- HeINEMANN, T.; AXTMANN, G. Y VON BERGMANN, K. (1993). Comparison of intestinal absorption of cholesterol with different plant sterols in man. European Journal Clinical Investigation, 23: 827-831.

- HETtIARACHCHY, N. S.; GLENN, K. C.; GNANAESBANDAM, R. Y JOHNSON, M. G. (1996). Natural antioxidant extracts from fenugreek (Trigo-nella foenumgraecum) for ground beef patties. Journal of Food Science, 61:516-519.

- HICKS, K.B Y MOREAU, R.A. (2001). Phytosterols and phytostanols: Functional food cholesterol busters. Food Technology, 55: 63-67.

- HOBERMAN, H.D. Y SAN GEORGE, R.C. (1988). Reaction of tobacco smoke aldehydes with human hemoglobin. Journal of Biochemical Toxicology, 3: 105-119.

- HU, M. Y SKIBSTED, L.H. (2002). Kinetics of reduction of ferrylmyoglobin by (-) epigallocatechin gallate and green tea extract. Journal of Agricultural and Food Chemistry, 50: 2298-3003. 
- HU, M.; McCLEMENTS, D. J. Y DECKER, E.A. (2003). Impact of whey protein emulsifiers on the oxidative stability of salmon oil-in-water emulsions. Journal of Agricultural and Food Chemistry, 51: 1435-1439.

- HURLING, R. Y MCARTHUR, H. (1996). Thawing, refreezing and frozen storage effects on muscle functionality and sensory attributes of frozen cod (Gadus morhua). Journal of Food Science, 61: 1289-1296.

- HUSS (1988). El pescado fresco: su calidad y cambios de su calidad. Col. FAO $\mathrm{N}^{\circ}:$ 29. pag 15-24.

- HUYNH, M.D.; KITTS, D.; HU, C. Y TRITES, A.W. (2007). Comparison of fatty acid profiles of spawning and non.spawning Pacific herring, Clupea harengus pallasi. Journal Comparative and Phisiology, Part B 146: 504-511.

- HUYNH, M.D.Y KITTS, D.D. (2009). Evaluating nutritional quality of pacific fish species from fatty acid signatures. Food Chemistry, 114: 912-918

- ICMSF (International Commission on Microbiological Specification for Foods). (1986). Sampling plans for fish and fishery products. In: Sampling for microbiological analysis. Principles and applications: Vol. 2. Microorganisms in foods (92-104). University of Toronto Press.Toronto. Canadá.

- IFIC (International Food Information Council). (2005). Functional foods fact sheet: omega-3 fatty acids. [online]. [citado julio 2007]. Disponible en: www.ific.org/publications/factsheets/ omega3fs.cfm?renderforprint $=1$

- IKAWA, K. (1998). Use of tea extracts (sanfood) in fish paste products. New Food Industries, 40: 33-39.

- INCORVAIA, I. S. (2012 a). Seminario sobre parásitos en peces marinos. Informe de Asesoramiento y Transferencia. INIDEP Nº74. 23 pp.

- INCORVAIA, I. S. (2012 b). Comentarios sobre las normativas de la unión europea sobre higiene de los productos de origen pesquero referida a parásitos. 2012. Informe de Asesoramiento y Transferencia INIDEP, Nº97.8 pp.

- INDEC (Instituto Nacional de Estadística y Censos) (2012). Tasa de mortalidad general por 100.000 habitantes, según principales causas de muerte y sexo. Total del país. Años 2005-2009 [online]. [citado julio 2012]. Disponible en: http://www.indec.gov.ar/. Fuente: Ministerio de Salud de la Nación. Dirección de Estadísticas e Información de Salud (DEIS).

- INTROZZI, A. (1995). Marine oils; its relation with human nutrition and atherosclerosis. Aceites y Grasas, 5: 114-118.

- JACOBSEN, C.; LeTC, M.; NIELSEN, N.S. Y MEYER, A. (2008). Antioxidant strategies for preventing oxidative flavour deterioration of foods enriched with $n-3$ 
polyunsaturated lipids: a comparative evaluation. Trends in Food Science and Technology, 19:76-93.

- JANKOWSKA, B.; ZAKES, Z.; ZMIJEWSKI T. Y SZCZEPKOWSKI, M. (2010). Fatty acid profile of muscles, liver and mesenteric fat in wild and reared perch (Perca fluviatilis). Food Chemistry, 118: 764-768.

- JAYAPRAKASHA, H.M. Y BRUECKNER, H. (1999). Whey protein concentrate: a potential functional ingredient for food industry. Journal of Food Science and Technology, 36:189-204.

- JAYAPRAKASHA, G.K.; SINGH, R.P. Y SAKARIAH; K.K. (2001). Antioxidant activity of grape seed (Vitis vinifera) extracts on peroxidation models in vitro. Food Chemistry, 73:285-290.

- JIANG, S. T., HWANG, D. C. Y CHEN, C. S. (1988). Denaturation and change in $\mathrm{SH}$ group of actomyosin from milkfish during frozen storage al $-20^{\circ} \mathrm{C}$. Journal of Agricultural and Food Chemistry, 36: 433-437.

- JIMENEZ-COLMENERO, F. (2007). Healthier lipid formulation approaches in meat-based functional foods. Technological options for replacement of meat fats by non-meat fats. Trends in Food Science and Technology, 18: 567-578.

- JOBLING, M. (1995). Environmental biology of fishes. Chapman \& Hall Publishers, Londres. $455 \mathrm{pp}$

- JONES, P.J.; RAEINI-SARJAZ, M. Y NTANIOS, F.Y. (2000). Modulation of plasma lipid levels and cholesterol kinetics by phytosterol versus phytostanol esters. Journal of Lipid Research, 41: 697-705.

- JONES, P.J.; VANSTONE, C.A.; RAEINI-SARJAZ, M. Y ST-ONGE, M.P. (2003). Phytosterols in low- and nonfat beverages as part of a controlled diet fail to lower plasma lipid levels. Journal of Lipid Research, 44: 1713-1719.

- KAITARANTA, J.K. (1992). Control of lipid oxidation in fish oil with various antioxidative compounds. Journal American Oil Chemistry Society, 69: 810-813.

- KARAKOLTSIDIS, P.A.; ZOTOS, A. Y CONSTANTINIDES, S.M. (1995). Composition of the commercially important Mediterranean finfish, crustaceans and mollusks. Journal of Food Composition and Analysis, 8: 258-273

- KATAN, M.B.; GRUNDY, S.M.; JONES, P.; LAW, M.; MIETTINEN, T. Y PAOLETTI, R. (2003). Efficacy and safety of plant stanols and sterols in the management of blood cholesterol levels. Mayo Clinic Proceedings, 78: 965-978.

- KAYA, Y. Y TURAN, H. (2010). Comparison of protein, lipid and fatty acids composition of anchovy (Engraulis encrasicolus L.1758) during the commercial catching season. Journal of Muscle Foods, 21: 474-483. 
- KE, P.J.; NASH, D.M. Y ACKMAN, R.G. (1977). Mackerel skin lipids as an unsaturated fat model system for the determination of antioxidative potency of TBHQ and other antioxidant compounds. Journal of the American Oil Chemists' Society, 54: 417-420.

- KÖSE, S. (2010). Evaluation of Seafood safety health hazards for traditional fish products: Preventive measures and monitoring issues. Turkish Journal of Fisheries and Aquatic Sciences, 10: 139-160.

- KOVALSKYS, I.; BAY, L.; RAUSCH HERSCOVICI, C. Y BERNER, E. (2003). Prevalencia de obesidad en una población de 10 a 19 años en la consulta pediátrica. Archivos Argentinos de Pediatría, 101: 441-447.

- KOZLOVA, T.A. Y KHOTIMCHENKO, S.V. (2000). Lipids and fatty acids of two pelagic cottoid fishes (Comephorus spp.) endemic to Lake Baikal. Comparative Biochemistry and Physiology Part B: Biochemistry and Molecular Biology, 126: 477485.

- LAW, M. (2000). Plant sterol and stanol margarines and health. British Medical Journal, 320: 861-864.

- LEE, S.; DECKER, E.A.; FAUSTMAN, C. Y MANCINI R.A. (2005). The effects of antioxidant combination on color and lipid oxidation in n-3 oil fortified ground beef patties. Meat Science, 70: 683-689.

- LEE, S.; FAUSTMAN, C.; DJORDJEVIC, D.; FARAJI, H. Y DECKER, E.A. (2006a). Effect of antioxidants on stabilization of meat products fortified whit $n-3$ fatty acids. Meat Science, 72: 18-24.

- LeE, S.; HERNANDEZ, P.; DJORDJEVIC, D.; FARAJI, H.; HOLLENDER, R. FAUSTMAN, C. Y DECKER, E.A. (2006b). Effect of antioxidants and cooking on stability of fatty acids in fortified meat products. Journal of Food Science, 71: 233-238.

- LISTON, J. (1980). Microbiology in fishery science. Advances in Fish Science and Technology Pp 138-157. Fishing News Books. Londres.

- LOPEZ-CABAllero, M.E.; GOMEZ-GUILlEN, M.C., PEREZ-MATEOS, M. Y MONTERO, P. (2005). A chitosan-gelatin blend as a coating for fish patties. Food Hydrocolloids, 19: 303-311

- LOPÉZ-CAZORLA, A. (1985). Edad, crecimiento y comportamiento migratorio de Brevoortia aurea (Osteichthyes, clupeidae) de Bahía Blanca (Argentina). Investigación Pesquera, 49: 297-313.

- LÓPEZ-LÓPEZ, I.; COFRADES, S.; RUIZ-CAPILLAS, C. Y JIMÉNEZCOLMENERO, F. (2009). Design and nutritional properties of potential functional frankfurters based on lipid formulation, added seaweed and low salt content. Meat Science, 83: 255-262. 
- LOVE, M.; AREF, M.M.; ÉLERIAN, M.K.; IRONSIDE, J.I.; MACKEAY, E.M. Y VARELA, M.G. (1965). Protein denaturation in frozen fish. Journal of the Science of Food and Agriculture, 16, 259-267.

- LUCCA, P. A. Y TEPPER, B. J. (1994). Fat replacers and the functionality of fat in foods. Trends in Food Science and Technology, 5: 12-19.

- LUND, M; HAVIID, M. Y SKIBSTED, L. (2007). The combined effect of antioxidants and modified atmosphere packaging on protein and lipid oxidation in beef patties during chill storage. Meat Science, 76: 226-233.

- LUPEA, A.X.; POP, M. Y CACIG, S. (2008). Structure-radical scavenging activity relationships of flavonoids from Ziziphus and Hydrangea extracts. Revista de Chimie, 59:309-313.

- LUTZ, M. (2009). Alimentos funcionales en la prevención de enfermedades crónicas no transmisibles. En:, Mariane Lutz y Alberto Edel León. Ed. Aspectos nutricionales y saludables de los productos de panificación. Universidad de Valparaiso. Valparaiso. pp, 38-50

- MACCHI, G.J. Y ACHA, E.M. (2000). Spawning time, frequency, and batch fecundity of Brazilian menhaden, Brevoortia aurea, in the Río de la Plata estuary between Argentina and Uruguay. Fishery Bulletin, 98: 283-289.

- MAESTRE DEL CURA, R. (2012). Mecanismos implicados en la acción antioxidante de polifenoles naturales en productos de la pesca y acuicultura. Tesis Facultad de Química. Santiago de Compostela. España

- MAGNEA, G.K. (2009). Application of additives in chilled and frozen white fish fillets. Tesis Universidad de Islandia.

- MAGYP (Ministerio de Agricultura, Ganadería y Pesca). (2012). Archivo de desembarques de la pesca marítima. [online]. [citado diciembre 2012]. Disponible en:http://www.minagri.gob.ar/site/pesca/pesca_maritima/02desembarques/anio.php?an io $=2012$.

- MANCA, E. (2004). Desarrollo de productos con valor agregado. [online]. [citado octubre 2009]. Disponible en: www.cfired.org.ar/esp2/indices/f1.htm

- MAQSOOD, S. Y BENJAKUL, S. (2009). Comparative studies of four different phenolic compounds on in vitro antioxidative activity and the preventive effect on lipid oxidation of fish oil emulsion and fish mince. Food Chemistry. DOI: 10.1016/j.foodchem.2009.06.004

- MARTINELlO, M.A. Y PRAMPARO, M. (2005). Antioxidant Potential of Rosemary Extracts Concentrated by Molecular Distillation. Información Tecnológica, 16: 17-20. 
- MASSA, A.E.; FERNANDEZ-COMPAZ, A. Y PENNISI FORELL, S.C. (2012). Determinación de la composición química de Engaulis anchita en función de la zona de captura y el tamaño de los ejemplares. Informe de Investigación № 77. 10/09/2012. $15 \mathrm{p}$.

- MATA, P. (2007). Alimentación funcional y hábitos de vida cardiosaludable [online]. [citado julio 2011]. Disponible en: http://www.informacionconsumidor.com/Documentacioacuten/tabid/57/Default.aspx

- MATSUMOTO, J. J. (1980). Chemical deterioration of muscle proteins during frozen storage. ACS Symposium series, 123: 95-124.

- MEdinA, I.; SATUE-GRACiA, M. T.; GeRMAN, J. B. Y FRANKEL, E. N. (1999). Comparison of natural polyphenol antioxidants from extra virgin olive oil with synthetic antioxidants in tuna lipids during thermal oxidation. Journal of Agricultural and Food Chemistry, 47:4873-4879.

- MEINDERT PELSER, W.; LINSSEN, J.P.H.; LEGGER, A Y HOUBEN, J.H. (2007). Lipid oxidation in n-3 faty acid enriched Dutch style fermented sausages. Meat Science, 75: 1-11.

- MELNIKOV, S.M.; SEIJEN TEN HOORN, J.W. Y EIJKELENBOOM, A.P. (2004). Effect of phytosterols and phytostanols on the solubilization of cholesterol by dietary mixed micelles: an in vitro study. Chemistry and Physics of Lipids, 127: 121141.

- MiNOZZO, M.G. (2010). Pate de pescado: alternativa para incremento da producao nas industrias pesqueiras. Tesis Universidad Federal de Parana. Brasil.

- MOHAN, M; RAMACHANDRAN, D.; SANKAR, T.V. Y ANANDAN, R. (2008). Physicochemical characterization of muscle proteins from different regions of mackerel (Rastrelliger kanagurta). Food Chemistry, 106:451-457.

- MOLINAS, J.; TORRENT, C. Y BURGOS, J. (2007). Frecuencia de consumo de alimentos fuente de ácidos grasos omega 3. Su relación con síntomas de asma y rinitis alérgica en adolescentes de la ciudad de Rosario. [online]. [citado junio 2009]. Disponible en: http://redalyc.uaemex.mx/redalyc/src/inicio/ArtPdfRed.jsp?iCve=87701908.

- MONTERO, P., GÓMEZ-GUILLÉN, M. C., Y BORDERÍAS, J. (1996). Influencia de la subespecie, estacionalidad y procedimientos de estabilización en la aptitud gelificante del músculo de sardina (Sardina pilchardus) congelado. Food Science and Technology International, 2: 111-122.

- MOORE, R. L.; DUNCAN, S. E.; RASOR, A. S.; EIGEL, W. N. Y O'KEEFE, S. F. (2012). Oxidative stability of an extended shelf-life dairy-based beverage system designed to contribute to heart health. Journal Dairy Science, 95 :6242-6251 
- MOREAU, R.A.; WHITAKER, B.D. y HICKS, K.B. (2002). Phytosterols, phytostanols, and their conjugates in foods: structural diversity, quantitative analysis, and health-promoting uses. Progress in Lipid Research, 41: 457-500.

- MOREAU, R.A. (2005). Phytosterols and phytosterol esters. En: Halthful lipids. Casimir C.A. and Oi-Ming L. eds. AOCS Press, Champaign, Illinoirs. pp. 335-360.

- MORENO CONDE, H.M. (2010). Restructuración en frío de músculo de pescado mediante la incorporación de alginato sódico y transglutaminasa microbiana. Tesis Facultad de Veterninaria, Universidad Complutense de Madrid. 402pp

- MORITA, R.Y. (1975). Psychrophilic bacteria. Bacteriological Review, 39:144167.

- MORÓN-FUENMAYOR, O. E. Y ZAMORANO-GARCÍA, L. (2003). Drip loss in different raw meat. Archivos Latinoamericanos de Producción Animal, 11: 125-127.

- MORR, C.V. Y HA, E.Y.W. (1993). Whey protein concentrates and isolates: processing and functional properties. Critical Reviews in Food Science and Nutrition, 33: 431-476.

- MURCIA, M.A. Y MARTINEZ-TOME, M. (2001). Antioxidant activity of resveratrol compared with common food additives. Journal of Food Protection, 64:379_ 384.

- MURPHY, S.; GILROY, D.; KERRY, J. Y KERRY, J. (2005). Surimi Gels Manufactured from Atlantic Whiting. Journal of Food Science, 70: C21-C24.

- MURRAY, C.K. Y SHEWAN, J.M. (1979). The microbial spoilage offish with special reference to the role of psychrotrophs. Cold tolerant microbes in spoilage and the environment. Academic Press. Pp 117-136. Londres.

- NASH, R.D.M.; VALENCIA, A.H. Y GEFFEN, A.J. (2006). The Origin of Fulton's Condition Factor- Setting the Record Straight. Fisheries, 31: 236-238.

- NIELSEN D, HYLDIG G, NIELSEN J Y NIERLSEN H. (2005). Lipid content in herring (Clupea harengus L.)-influence of biological factors and comparison of different methods of analyses: solvent extraction, Fatmeter, NIR and NMR. LWT - Food Science and Technology, 38: 537-548.

- NINAN, G.; BINDU, J Y JOSEPH, J. (2010).Frozen storage studies of valueadded minced-based products from tilapia (Oreochromis mossambicus, Peters 1852). Journal of Food Processing and Preservation, 34: 255-271.

- OlIVARES, S. Y ZACARIAS, I. (2002). Guía de alimentación saludable y necesidades nutricionales del adulto. Ministerio de Salud, OMS/OPS e, instituto de Nutrición y Tecnología de los alimentos (INTA), Chile. Informe Técnico. [online]. [citado septiembre 2007]. Disponible en: http://163.247.51.46/nutricion/ Documentos /3GuiAli.pdf 
- OMS (ORGANIZACIÓN MUNDIAL DE LA SALUD). (2004). 57a ASAMBLEA MUDIAL DE LA SALUD. Estrategia mundial sobre régimen alimentario, actividad física y salud. [online]. [citado octubre 2009]. Disponible en: www.propia.org.ar/ descargas/apicobade.pdf

- OMS (ORGANIZACIÓN MUNDIAL DE LA SALUD). (2008). [online]. [citado febrero 2013].

Disponible en: http//www.who.int/entity/dietphysicalactivity/WHOWEF_report_Jan2008_FINAL.pdf

- ORBANA, E.; NEVIGATOA, T.; DI leNAA, M.; MASCIA, M.; CASINIA, I.; CAPRONIA, R. Y RAMPACCIB, M. (2011). Total volatile basic nitrogen and trimethylamine nitrogen levels during ice storage of European hake (Merluccius merluccius): A seasonal and size differentiation. Food Chemistry, 128:679-682

- OSTLund, R.E.; RACETTE, S. B.; OKEKE, A. y STENSON, W. F. (2002). Phytosterols that are naturally present in commercial corn oil significantly reduce cholesterol absorption in humans. American Journal of Clinical Nutrition, 75: 10001004.

- OSTLUND, R.E. (2007). Phytosterols, cholesterol absorption and healthy diets. Lipids, 42: 41-45.

- OTWELL, W. S. Y GIDDINGS, G. G. (1980). Scanning Electron Microscopy of Squid, Loligo peale: raw, cooked, and frozen mantle. Marine Fisheries Review, 42: 6773.

- OZUGUL, F.; TAYLOR, K.D.; QUANTICK, P. Y OZAGUL, Y. (2002). Biogenic amines formation in Atlantic herring (Clupea harengus) stored under modified atmosphere packaging using a rapid HPLC method. International Journal of Food Science and Technology, 37: 515- 522.

- PAlAZOlO, G.G.; MITIDIERI, F.E. Y WAGNER, J.R. (2003). Relationship between interfacial behaviour of native and denatured soybean isolates and microstructure and coalescence of oil in water emulsions - effect of salt and protein concentration. Food Science and Technology International, 9:409-41.

- PAREDI, M. E. Y CRUPKIN, M. (1997). Biochemical properties of actomyosin from frozen stored mantles of squid (Illex argentinus) at different sexual maturation stages. Journal of Agricultural and Food Chemistry, 45: 1629-1632.

- PARK, J. W. (1994). Functional protein additives in surimi gels. Journal of Food Science, 59: 525-527.

- PATASHNIK, M.; KUDO, G. Y MIYAUCHI, D. (1974). Bone particle content of some minced fish muscle products. Journal of Food Science, 39: 588-591.

- PAZOS, M.; ALONSO, A.; FERNÁNDEZ-BOLAÑOS, J.; TORRES, J.L. Y MEDINA, I. (2006). Physicochemical properties of natural phenolics from grapes and 
olive oil byproducts and their antioxidant activity in frozen horse mackerel fillets. Journal of Agricultural and Food Chemistry, 54:366-373.

- PAZOS, M.; IGLESIAS, J.; MAESTRE, R. Y MEDINA, I. (2010). Structureactivity relationships of polyphenols to prevent lipid oxidation in pelagic fish muscle. Journal of Agricultural and Food Chemistry, 58:11067-11074.

- PEARCE, K.N. Y KINSELLA, J.E. (1978). Emulsifying properties of proteins: evaluation of a turbidimetric technique. Journal of Agricultural and Food Chemistry, 26: 716-723.

- PEÑA-RAMOS, E. A. Y XIONG, Y. (2003). Whey and soy protein hydrolysates inhibit lipid oxidation in cooked pork patties. Meat Science, 64: 259-263.

- PENNISI FORELL, S.C., CALIFANO, A.N. Y MANCA, E.A. (2009). Characterization of edible muscle from a sub-utilized marine species, saraca (Brevoortia aurea). En: Proceedings of III International Congress of Science and Food Technology (Vol. IV, pp254-262). Córdoba, Argentina.

- PENNISI FORELL, S.C.; RANALLI, N.; ZARITZKY, N.E.; ANDRES, S.C. Y CALIFANO, A.N. (2010). Effect of type of emulsifiers and antioxidants on oxidative stability, colour and fatty acid profile of low-fat beef burgers enriched with unsaturated fatty acids and phytosterols. Meat Science, 86: 364-370.

- PEREZ, O.; WARGON, V. Y PILOSOF, A.M. (2006). Gelation and structural characteristics of incompatible whey proteins/ hydroxypropylmethylcellulose mixtures. Food Hydrocolloids, 20: 966-974.

- PINELO, J.M.(2003). Antioxidante a partir de residuos de uva. Influencia del modo de operación y de las variables de proceso. Tesis Universidad de Santiago de Compostela.

- PIÑERO, M.P.; PARRA, K.; HUERTA-LEIDENZ, N.; ARENAS DE MORENO, L.; FERRER, M.; ARAUJO, S. Y BARBOZA, Y. (2008). Effect of oat's soluble fibre ( $\beta$ glucan) as a fat replacer on physical, chemical, microbiological and sensory properties of low-fat beef patties. Meat Science, 80: 675-680.

- PLAT, J. y R. P. MENSICK. (2001). Effects of plant sterols and stanols on lipid metabolism and cardiovascular risk. Nutrition, Metabolism \& Cardiovascular Diseases, 11: $31-40$.

- PlumB, G. W.; PASCuAl-Teresa, S.; CheyNiER, V. Y WILliamson, G. (1998). Antioxidant propeties of catechins and proanthocyanidins: effect of polymerisation, galloylation and glycosilation. Free Radical Research, 29: 351-358.

- PROPIA (PROGRAMA DE PREVENCIÓN DEL INFARTO EN ARGENTINA). (2004). Situación de esperanza en Argentina. [online]. [citado octubre 2006]. Disponible en: www.nutrinfo.com.ar 
- PROPIA (PROGRAMA DE PREVENCIÓN DEL INFARTO EN ARGENTINA). (2005). El aceite de girasol de alto oleico y la prevención de la aterosclerosis. [online]. [citado octubre 2006]. Disponible en: www.propia.org.ar/descargas/micoyen20.pdf

- RADIČEVIĆ, T.; RAIČEVIĆ, S. Y NIKETIĆ, V. (2002). Bighead carp myosin stability tb heat and frozen storage. Acta veterinaria, 52: $151-161$.

- RAdOVANOVIC, A.; RADOVANOVIC, B. Y JOVANCICEVIC, B. (2009). Free radical scavenging and bacterial activities of southern Serbian red wines. Food Chemistry, 117:326-331.

- REFSGAARD, H. H. F., BROCKHO, P. B. Y JENSEN, B. (1999). Sensory and chemical changes in farmed Atlantic salmon (Salmo salar) during frozen storage. Journal of Agricultural and Food Chemistry, 46: 3473-3479.

- RICHARDS, M.P. Y HULTIN, H.O. (2000). Effect of pH on lipid oxidation using trout hemolysate as a catalyst: a possible role for deoxyhemoglobin. Journal of Agricultural and Food Chemistry, 48: 3141-3147

- RICHARDS, M.P.; MODRA, A.M. Y LI, R. (2002). Role of deoxyhemoglobin in lipid oxidation of washed cod muscle mediated by trout, poultry and beef hemoglobins. Meat Science, 62: 157-163

- RICHHEIMER, S.L.; BERNART, M.W.; KING, G.A.; KENT, M.C.Y BAILEY, D.T. (1996). Antioxidant activity of lipid-soluble phenolic diterpenes from rosemary. Journal American Oil Chemistry Society, 73:507-514

- RODRíGUEZ GUERRERO, M. (2007). Conservas de pescado y sus derivados. Tecnología en Alimentos. Universidad del Valle. 63pp.

- ROSSI, R.; GRIMALDI, T.; ORIGLIANI, G.; FANTINI, G.; COPPI, F. y MODERNA, M.G. (2002). Menopause and cardiovascular risk. Pathophysiology of Haemostasis and Thrombosis, 32:325-328

- ROYO, M.A. (2004). Recomendaciones nutricionales y alimentarias para una dieta cardiosaludable. Revista Española de Nutrición Comunitaria ,10:122-143.

- RUILOVA, M. (2008). Factors affecting water holding capacity and texture in cooked albacore tuna (Thunnus alalunga). Tesis, Universidad Estatal de Carolina del Norte.

- SABORIDO-REY. (2008). Ecología de la reproducción y potencial reproductivo en las poblaciones de peces marinos. [online]. [citado junio 2012]. Disponible en: http://digital.csic.es/bitstream/10261/7260/1/Curso\%20Ecologia\%20reproduccion\%20y \%20potencial\%20reproductivo\%20en\%20las\%20poblaciones\%20de\%20peces\%20ma rinos.pdf 
- SALLAM, K. (2007). Antimicrobial and antioxidant effects of sodium acetate, sodium lactate, and sodium citrate in refrigerated sliced salmon. Food Control, 18: 566-575

- SAlLAM, K.; AHMED, A.M.; ElGAZZAR, M.M. Y ELDALY, M.A. (2007). Chemical quality and sensory attributes of marinated Pacific saury (Cololabis saira) during vacuum-packaged storage at $4^{\circ} \mathrm{C}$. Food Chemistry, 102: 1061-1070

- SÁNCHEZ, M.F. (1989). Características morfológicas del aparato digestivo y espectro trófico de la saraca (Brevoortia aurea, Clupeiformes, Pisces). Physis, 47:2133.

- SÁNCHEZ-ALONSO, I.; SOLAS, M.T. Y BORDERÍAS, A.J. (2007). Physical study of minced fish muscle with a white-grape by-product added as an ingredient. Journal of Food Science, 72: E94-E101.

- SÁNCHEZ-ALONSO, I.; HAJÍ-MALEKI, R. Y BORDERÍAS, A.J. (2007). Wheat fiber as a functional ingredient in restructured fish product. Food Chemistry, 100(3): 1037-1043.

- SÁNCHEZ-ALONSO, I.; JIMÉNEZ-ESCRIG, A.; SAURA-CALIXTO, F. Y BORDERÍAS, A.J. (2008). Antioxidant protection of white grape pomace on restructured fish products during frozen storage. LWT - Food Science and Technology, 41: 42-50.

- SÁNCHEZ-ALONSO, I. Y BORDERÍAS, A.J. (2008). Technological effect of red grape antioxidant dietary fibre added to minced fish muscle. International Journal of Food Science \& Technology, 43:1009-1018.

- SÁNCHEZ-ALONSO, I.; CARECHE, M.; MORENO, P.; GONZÁlEZ, M.J. Y MEDINA, I. (2011). Testing caffeic acid as a natural antioxidant in functional fish-fibre restructured products. LWT - Food Science and Technology, 44: 1149 - 1155.

- SCHMIDT, R.H., PACKARD, V.S. Y MORRIS, H.A. (1984). Effect of processing on whey protein functionality. Journal of Dairy Science, 67:2723-2733.

- SCHUBRING, R. (1999). DSC studies on deep frozen fishery products. Thermochimica Acta, 337: 89-95.

- SHAHIDI, F. (2004). Functional foods: their role in health promotion and disease prevention. Journal of Food Science, 69: R146-R149.

- SHEARD, P.; NUTE, G. Y CHAPPELL A. (1998). The effect of cooking on the chemical composition of meat products with special reference to fat loss. Meat Science, 49: 175-191.

- SHEWAN, J.M. (1962). The bacteriology of fresh and spoiling fish and some related chemical changes. Recent Advances in Food Science, 1:1167-193. 
- SHEWAN, J.M. (1977). The bacteriology of fresh and spoiling fish and the biochemical changes induced by bacterial action. In Handling, Processing and Marketing of Tropical Fish. Pp. 51-66. Tropical Products Institute. London.

- SIDDAIAH, D.; VIDYA, G.; RAJU, D. Y CHANDRASEKHAR, T.C. (2001). Changes in lipids, proteins and kamaboko forming ability of silver carp (Hypophthalmichthys molitrix) mince during frozen storage. International Food Research, 34: 47-53.

- SIGURGISLADOTTIR, S., INGVARSDOTTIR, H., TORRISSEN, O. J., CARDINAL, M. Y HAFSTEINSSON, H. (2000) Effects of freezing/thawing on the microstructure and the texture of smoked Atlantic salmon (Salmo salar). Food Research International, 33: 857-865.

- SIKORSKI, Z.E. (1994). Tecnología de los productos pesqueros del mar: recursos, composición nutritiva y conservación. Ed. Acribia, Zaragoza.

- SILVEIRA RODRIGUEZ, M. B; MONEREO MEGIAS, S. Y MOLINA BAENA, B. (2003). Alimentos funcionales y nutrición óptima: ¿Cerca o lejos?. Revista Española de Salud Pública, 77:317-331.

- SMITHERS, G.W. (2008). Whey and Whey Proteins - From 'Gutter-to-Gold'. International Dairy Journal, 18:695-704.

- SOHN, J.; USHIO, H.; ISHIDA, N.; YAMASHITA, M.; TERAYAMA, M. Y OHSHIMA, T. (2007). Effect of bleeding treatment and perfusion of yellowtail on lipid oxidation in post-mortem muscle. Food Chemistry, 104: 962-970.

- SOTELO, C.G.; PIÑEIRO, C. Y PÉREZ-MARTíN, R. Z. (1995). Denaturation of fish proteins during frozen storage: role of formaldehyde. Zeitschrift für lebensmitteluntersuchung und forschung $A, 200,14-23$.

- SPANGGAARD, B.; JOERGENSEN, L.; GRAM, L. Y HUSS, H. (1993). Antiobiotic resistance against oxytetracycline and oxolinic acid of bacteria isolated from three freshwater fish farms and an unpolluted stream in Denmark. Aquaculture, 115: 195-207.

- SUBHADRA, B.; LOCHMANN, R.; RAWLES, S. Y CHEN, R. (2006). Effect of dietary lipid source on the growth, tissue composition and hematological parameters of largemouth bass (Micropterus salmoides). Aquaculture, 255: 210-222

- SURENDRAN, P. Y GOPAKUMAR, K. (1981). Selection of bacterial flora in the chlortetracycline treated oil sardine (Sardinella longiceps), Indian mackerel (Rastrelliger kanagurta) and prawn (Metapenaeus dobsoni) during ice storage. Fishery Technology, 18: 133-141.

- SUZUKI, T. (1987). Tecnología de las proteínas del pescado y krill. Ed. Acribia. Zaragoza. 
- tanAMATI, A.; OliVEIRA, C.; VISENTAINER, J.; MATSUSHITA, M. Y SOUZA, E. (2005). Comparative study of total lipids in beef using chlorinated solvent and low-toxicity solvent methods. Journal of the American Oil Chemisty Society, 82: 393-397.

- TANG, S.; SHEEHAN, D.; BUCKLEY, D.J; MORRISSEY, P.A. Y KERRY, J.P. (2001). Anti-oxidant activity of added tea catechins on lipid oxidation of raw minced red meat, poultry and fish muscle. International Journal of Food Science and Technology, $36: 685-692$.

- TEKIN, H.; SARICOBAN, C. Y YILMAZ, M.T. (2010). Fat, wheat bran and salt effects on cooking properties of meat patties studied by response surface methodology. International Journal of Food Science and Technology, 45:1980-1992.

- TERREJON RAMOS, P. (1996) Agregación de proteínas de músculo de pescado congelado, acción de formaldehido. Tesis Facultad de Farmacia Universidad Complutense de Madrid.

- TIRONI, V. (2005). Rancidez oxidativa en salmón de mar. Interacción lípidos oxidados proteínas". Tesis Facultad de Ciencias Exactas (UNLP).

- TIRONI, V.; TOMÁS, M. Y AÑON, C. (2007). Lipid and protein deterioration during the chilled storage of minced sea salmon (Pseudopercis semifasciata). Journal of the Science of Food and Agriculture, 87: 2239-2246.

- TIRONI, V., TOMÁS, M. Y AÑÓN, C. (2010). Quality loss during the frozen storage of sea salmon (Pseudopercis semifasciata). Effect of rosemary (Rosmarinus officinalis L.) extract. LWT- Food Science and Technology: 43, 263-272.

- TOCHER D. (2003). Metabolism and functions of lipids and fatty acids in teleost fish. Reviews in Fisheries Science, 11: 107-184.

- TOKUR, B.; POLAT, A.; BEKLEROK, G. Y OZKUTUK, S. (2004). The quality changes in tilapia (O. niloticus) burger during frozen storage. European Food Research and Technology, 218: 420-423.

- TOKUR, B.; OZKUTUK, S.; ATICI, E.; OZYURT, G. Y OZYURT, C.E. (2006). Chemical and sensory quality changes of fish fingers, made from mirror carp (Cyprinus carpio L., 1758), during frozen storage $\left(-18^{\circ} \mathrm{C}\right)$. Food Chemistry, 99: 335-341.

- TONG, L. M.; SASAKI, S.; MCCLEMENTS, D.J. Y DECKER, E. A. (2000a).Mechanisms of the antioxidant activity of a high molecular weight fraction of whey. Agriculture Food Chemistry, 48: 1473- 1478.

- TONG, L. M.; SASAKI, S.; MCCLEMENTS, D. J. Y DECKER, E. A. (2000b). Antioxidant activity of whey in a salmon oil emulsion. Journal of Food Science, 65: 1325-1329. 
- TOUNS, M.S.; OUERGHEMMI, I.; WANNES, W.A.; KSOURI; R.; ZEMN, H.; MARZOUK, B. Y KCHOU, M.E. (2009). Valorization of three varieties of grape. Industrial Crops and Products, 30:292-296.

- TOURIÑO O, S.; SElGA, A.; JIMENEZ, A.; JULIA, L.; LOZANO, C.; LIZARRAGA, D. L.; CASCANTE, M. Y TORRES, J. L. (2005). Procyanidin fractions from pine (Pinus pinaster) bark: radical scavenging power in solution, antioxidant activity in emulsion, and antiproliferative effect in melanoma cells. Journal of Agricultural and Food Chemistry, 53: 4728-4735.

- TUNICK, M.H. (2008). Whey Protein Production and Utilization. En: Whey Processing, Functionality and Health Benefits. Onwulata, C.I. y Huth, P.J., eds. WileyBlackwell, Ames, lowa.

- ULBRICHT, T.L.V. Y SOUTHGATE, D.A.T. (1991). Coronary Heart Disease Dietary Factors. Lancet, 338: 985-992.

- UNDELAND, I; EKSTRAND, B. Y LINGNERT, H. (1998). Lipid oxidation in minced herring (Clupea harengus) during frozen storage: influence of washing and precooking. Journal of Agricultural and Food Chemistry, 46: 2319-2328

- UNDELAND, I.; HULTIN, H.O. Y RICHARDS, M.P. (2002). Added triacylglycerols do not hasten hemoglobin-mediated lipid oxidation in washed minced cod muscle. Journal of Agricultural and Food Chemistry, 50: 6847-6853.

- USYDUS, Z.; SZLINDER-RICHERT, J.; ADAMCZYK, M. Y SZATKOWSKA, U. (2011). Marine and farmed fish in the Polish market: Comparison of the nutritional value. Food Chemistry, 126: 78- 84.

- VAlenZUELA, A. Y NIETO, S. (1995). Los antioxidantes: protectores de la calidad en la industria alimentaria. Aceites y Grasas, 20: 310-321.

- VAlENZUELA, A.; SANHUEZA, J. Y NIETO, S. (2000). Ácidos grasos omega-3 de cadena larga en la salud y nutrición humana y animal: un modelo para el desarrollo de alimentos funcionales. Aceites y Grasas, 41: 526-533.

- VALENZUELA, A.; SANHUEZA, J. Y NIETO, S. (2002). ¿Es posible mejorar la calidad nutricional de los aceites comestibles?. Revista Chilena de Nutrición, 29: 174180.

- VAlenZuela, A.; SANHUEZA, J. y NIETO, S. (2003). Revision: Natural antioxidants in functional foods: from food safety to health benefits. Grasa y Aceites, 54: 295-303.

- VAlENZUELA, A. Y RONCO, A. (2004). Fitoesteroles y fitoestanoles: aliados naturales para la protección de la salud cardiovascular. Revista Chilena de Nutrición, 21:161-169. 
- VALENZUELA, A. Y SANHUEZA, J. (2009). Marine oils; nutritional and food science relevance. Revista Chilena de Nutrición, 36: 246-257.

- VAlFRÉ, F.; CAPRINO, F. Y TURCHINI, G.M.(2003). The health benefit of seafood. Veterinary Research Communications, 27: 507-512.

- VALLS, J., PAREDES, A., Y GONZÁLEZ, D. (2006). Estabilidad de filetes de sardina (Sardinella aurita V.) en almacenamiento congelado a $-18^{\circ} \mathrm{C}$. Revista científica, 2: $176-185$.

- VAN DEN HOVEN, M. (1987). Functionality of dairy ingredients in meat products. Food Technology, 41: 72-73, 76-77, 103.

- VARNAM, A. Y SUTHERLAND, J.P. (1995) Leche y productos lacteos. En: Tecnología, química y microbiología. Ed: Acribia. Zaragosa.

- VENEGAS, N.; MARAMBiO, E.; INSUNZA, M., SOTO, A. Y ARRIETA, A. (1990). Control microbiológico de alimentos, técnicas actualizadas y métodos acelerados. Editorial Santiago. Universidad de Chile. Chile.

- VERA, R.; ENGLISH, P.; VARGAS, K. Y BRIONES, I. (2009).Lipid profile of commercial beef cuts from grazing, suckling calves. Grasas y Aceites, 60: 482-489.

- WAGNER, J. R. Y AÑON, M.C. (1985). Effect of freezing rate on the denaturation of myofibrillar proteins. International Journal of Food Science and Technology, 20: 735-744.

- WANG, C.C.; HARRIS, W.S.; CHUNG, M.; LICHTENSTEIN, A.H.; BALK, E. M. Y KUPELNICK, B. (2006). n-3 Fatty acids from fish or fish-oil supplements, but not alpha-linolenic acid, benefit cardiovascular disease outcomes in primary- and secondary-prevention studies: a systematic review. American Journal of Clinical Nutrition, 84: 5-17.

- WATTHANPIMOL, S. (2011). Physical and oxidative stability of fish oil-inwater emulsions prepared with preheated whey protein and maltodextrins. Tesis. Universidad de Tennessee.

- WONG, J.; LAU, Y. Y YAMAMOTO, M. (1978). Mechanical fish deboners: influence of various perforation sizes on bone content and texture of minced fish flesh. Journal of Food Science, 43: 807-809.

- XU, C.M.; ZHANG, Y.L.; WANG, J. Y LU, J.A. (2010). Extraction, distribution and characterisation of phenolic compounds and oil in grapeseeds. Food Chemistry, 122:688-694.

- YAMAMOTO, M. Y WONG, J. (1974). Simple chemical method for isolating bone fragments in minced fish flesh. Journal of Food Science, 39: 1259-1260.

- ZABOUKAS N, MILIOU H, MEGALOFONOU P Y MORAITOU M. (2006). Biochemical composition of the Atlantic bonito Sarda sarda for the Aegean Sea 
(eastern Mediterranean Sea) in different stages of sexual maturity. Journal of Fish Biology 69: 347-362.

- ZAYAS, J. F. (1997). Water holding capacity of proteins. In Zayas J.F. (Eds), Functionality of proteins in food, (pp. 76-133). Berlin, Germany: Springer Publishing Map.

- ZEVCHAK, S.E. (2007).The impact of agglomeration on flavor and flavor stability of Whey Proteins. Tesis Universidad Estatal de Carolina del Norte.

- ZHANG, M., MITTAL, G. S. Y BARBUT, S. (1995). Effects of test condition on the water holding capacity of meat by centrifugal method. LWT - Food Science and Technology, 28, 50-55.

- ZLATANOS, S. Y LASKARIDIS, K. (2007). Seasonal variation in the fatty acid composition of three Mediterranean fish - sardine (Sardina pilchardus), anchovy (Engraulis encrasicholus) and picarel (Spicara smaris). Food Chemistry, 103:725-728.

- ZORRILLA, S.; ROVEDO, C. Y SINGH, P. (2000). A new approach to correlate textural and cooking parameters with operating conditions during doublé-sided cooking of meat patties. Journal of Texture Studies, 31: 499-523. 